NBER WORKING PAPER SERIES

\title{
FREEING FINANCIAL EDUCATION VIA TABLETS: EXPERIMENTAL EVIDENCE FROM COLOMBIA
}

\author{
Orazio Attanasio \\ Matthew Bird \\ Lina Cardona-Sosa \\ Pablo Lavado \\ Working Paper 25929 \\ http://www.nber.org/papers/w25929 \\ NATIONAL BUREAU OF ECONOMIC RESEARCH \\ 1050 Massachusetts Avenue \\ Cambridge, MA 02138 \\ June 2019
}

This research was funded by Innovations for Poverty Action's Global Financial Inclusion Innovation and Research Fund, which was supported by Citi Foundation. We also acknowledge funding from the USAID-Skoll Innovation Investment Alliance which, with technical support from Mercy Corps, financed the final wave of data collection. We thank Veronica Frisancho, Xavi Giné, Dean Karlan, Olivia Mitchell, Silvia Prina, and Bilal Zia for inputs at various stages of the research and analysis. We thank Colombia's Ministry of Social Prosperity, especially Mariana Escobar Uribe and Maria Jose Uribe, for their collaboration. We are grateful to Fundación Capital, including Any Benitez, Carolina Bonilla, Laura Cordero, Rodrigo de Reyes, Magali de Varax, Franz Gómez, Miquel Jordana, Najin Kim, Yves Moury, Ana Pantelic, Mauricio Romero, and Claudia Vergara, for implementation. We are grateful to Rebecca Rouse, Beniamino Savonitto, and Pooja Wagh from Innovations for Poverty Action (IPA) for support, as well as Sebastian Chaskel, Juan Sebastian Leiva, Juan Camilo Medina, Pablo Villar, and, especially, Marta Carnelli from IPA Colombia for excellent field support and oversight. Finally, we thank Ami Ichikawa, Bruno Esposito, Ana Paula Franco, and Jorge Zavala for research assistance at the Universidad del Pacífico. The views expressed herein are those of the authors and do not necessarily reflect the views of the National Bureau of Economic Research.

NBER working papers are circulated for discussion and comment purposes. They have not been peer-reviewed or been subject to the review by the NBER Board of Directors that accompanies official NBER publications.

(C) 2019 by Orazio Attanasio, Matthew Bird, Lina Cardona-Sosa, and Pablo Lavado. All rights reserved. Short sections of text, not to exceed two paragraphs, may be quoted without explicit permission provided that full credit, including $(\odot)$ notice, is given to the source. 
Freeing Financial Education via Tablets: Experimental Evidence from Colombia

Orazio Attanasio, Matthew Bird, Lina Cardona-Sosa, and Pablo Lavado

NBER Working Paper No. 25929

June 2019

JEL No. D14,D18,G21,I22,I38,O15

\begin{abstract}
Financial knowledge is critical for making sound decisions that foster financial health and protect consumers from predation. A widely-used tool for building this capability is financial education. Yet evidence suggests that conventional approaches which teach concepts in classroom-style settings are ineffective and expensive at scale, especially for lower-income users. More recent findings indicate that customizing financial education to the needs, interests, and location of participants may increase impact, though doing so in a cost-effective and scalable way remains challenging. This randomized evaluation of a tablet-based financial education program with mostly female recipients of a conditional cash transfer (CCT) program in Colombia offers evidence for how to design and scale an effective digital-based financial education program. Results indicate that the LISTA Initiative had significant positive impacts on financial knowledge, attitudes, practices, and performance, increasing for poorer, less educated, and more rural populations, with users exhibiting increased financial health over two years later. Critical mechanisms included well-designed content and a social learning component. Yet the longerterm impact on formal financial inclusion was limited, suggesting the possible benefits of combining supply-side solutions with financial education interventions.
\end{abstract}

Orazio Attanasio

Department of Economics

University College London

Gower Street

London WC1E 6BT

UNITED KINGDOM

and NBER

o.attanasio@ucl.ac.uk

Matthew Bird

Centro de Investigación de la Universidad

del Pacífico

Universidad del Pacífico

Av. Sánchez Cerro 2098, Jesús María

Lima, Perú

bird_md@up.edu.pe

\author{
Lina Cardona-Sosa \\ Institute for Fiscal Studies \\ 7 Ridgmount Street \\ London WC1E 7AE \\ United Kingdom \\ lina_s@ifs.org.uk \\ Pablo Lavado \\ Centro de Investigación de la Universidad \\ del Pacífico \\ Universidad del Pacífico \\ Av. Sánchez Cerro 2050 \\ Jesús María Lima, Perú \\ p.lavadopadilla@up.edu.pe
}

A randomized controlled trials registry entry is available at AEARCTR-0000696

A Supplementary Material is available at http://www.nber.org/data-appendix/w25929 


\section{Introduction}

Around the world, levels of financial literacy correlate with better financial outcomes (Lusardi and Mitchell, 2014). This empirical relationship has provided justification for financial education interventions, which seek to transfer information, knowledge, and skills for managing financial flows 1 Yet evidence of the impact of financial education programs and human capital theories of financial knowledge indicate that the relationship between financial literacy and financial outcomes is more complex than a simple case of cause (Hastings et al., 2013; Lusardi et al., 2017).

Evidence of the effects of financial education remains mixed (Fernandes et al., 2014; Miller et al. 2015, Kaiser and Menkhoff, 2017). Comparisons are difficult because program design and quality vary based on user type, objectives, content, channel, intensity, and duration, to name a few. Interventions targeting rural farmers in Rwanda, adolescents in Brazilian high schools, and military enlistees at their place of work in the United Sates will differ. Regardless, some lessons have emerged as meta-analytic reviews have incorporated more experimental evidence and adopted more rigorous analytic methods. Financial education has been shown to increase knowledge, savings, and record-keeping, domains in which the user has more control, compared to debt (Miller et al., 2015 , Kaiser and Menkhoff, 2017). Consistent impact is harder to create among lower-income participants in developing countries as well as among higher-income users in more developed countries (Kaiser and Menkhoff, 2017). Studies reveal that the number of hours of program exposure, i.e., intensity, relates to impact (Miller et al., 2015; Kaiser and Menkhoff, 2017). Despite evidence of a financial literacy gender gap favoring males, differential impacts by gender have not been found Kaiser and Menkhoff, 2017), (Bucher-Koenen et al. 2017). People with greater self-efficacy or locus of control appear to benefit more from financial education (Fernandes et al., 2014; Miller et al., 2015), suggesting that programs should also target psychological components. Although financial tasks differ depending upon where one is in the life cycle, no systematic age effects emerge (Kaiser and Menkhoff, 2017).

Human capital theories, which model the endogenous relationship between financial literacy and financial outcomes over the life cycle, propose explanations for how and when interventions may have impact (Jappelli and Padula, 2013, Lusardi et al., 2017). Model predictions for the United States show that the differential life-cycle investment in financial knowledge among income groups with varying returns explains between 30 and 40 percent of retirement wealth inequality (Lusardi et al. 2017). If social insurance programs exist, it may be rational for the lower-income population to not invest in financial literacy (Hubbard et al., 1995; Lusardi et al. 2017). Finally, the stock of financial literacy early in life is predicted to deliver compounded returns across the life-cycle (Jappelli and Padula, 2013; Lusardi et al., 2017). The above models offer an explanation for why interventions among lower-income populations may lead to less impact and why it may be more

\footnotetext{
${ }^{1}$ For example, results from the Financial Development Barometer, an online poll conducted for the 2014 World Bank Global Financial Development Report (GFDR), indicated that over 60 percent of officials from 21 developed and 54 developing economies asserted that financial education was the most effective way to increase financial access to lower-income citizens (see Miller et al., 2015).
} 
cost-effective to focus on financial literacy earlier in life.

Regardless, what some considered the disappointing results of financial education interventions Willis, 2011) led to a focus on the larger concept of financial inclusion and supply-side components (Hastings et al. 2013). In developing countries, for example, scholars and practitioners have partnered to apply behavioral economic principles to product redesigns targeting limited self-control and inattention. Commitment devices have proven effective, especially those of the soft variety, such as labeled accounts, lock-boxes, and triggers (Ashraf et al., 2006; Duflo et al., 2011; Dupas and Robinson, 2013; Brune et al., 2017). Changes in behavior may also reverse the direction of the causal relationship between financial education programs and practices. While human capital theories have not disentangled whether knowledge leads to behavior or behavior to knowledge, impact evaluations of product redesigns offer evidence for the latter. In Rural Kenya, the effects of a temporary incentive to save can persist for at least three years after the intervention Schaner, 2018). In Afghanistan, default assignment into a savings treatment shifted attitudes towards saving and increased the likelihood of doing so 18 months after the experiment ended. The authors suggest that the experience of benefits from saving helped change perceptions (Blumenstock et al., 2018).

Yet supply-side interventions, such as the savings products described above, may still leave unaddressed an important goal of financial education: empowering consumers to take control of their financial lives, improve their decisions, and protect themselves against predation (Hastings et al. 2013). These issues are particularly relevant given expanding global access to the formal financial system. In developing countries, consumer empowerment and protection become even more critical with government adoption of financial inclusion policies (many of which are tied to cash transfer programs) and technological innovations (such as mobile banking and digital payment services), which increase the number of people entering the formal financial system (Karlan et al. 2016a; Demirguc-Kunt et al., 2017). One estimate claims that three of every four newly banked global poor had never received any form of financial training (Deb and Kubzansky, 2012). Merely banking the unbanked is thus not enough (Dupas et al. 2018). Just as financial education gave way to financial inclusion, practitioners have begun to reconsider the objectives and implications of financial inclusion policies and refocus on financial health, the ability to create and manage financial systems that protect against shocks and create opportunities (CSFI, 2017; Prabhajar, 2018).

As financial access increases for lower-income populations, the lack of financial literacy or capability may hinder optimal use of new products or, at worst, leave consumers vulnerable to predatory services, as seen in the sub-prime mortgage crisis in the United States or microcredit overindebtedness crises in Nicaragua and India (Guérin et al. 2015, Mader, 2015, Bateman et al., 2018) .2 A critical challenge, especially in developing countries, is how to offer impactful, cost-effective, and scalable financial education that helps lower-income citizens become more informed consumers who can use newly accessed financial services to better leverage their earned or transferred resources to

\footnotetext{
${ }^{2}$ Beyond supply- and demand-side interventions, regulation is a third option for protecting consumers against predatory financial practices, as seen with the creation of the Consumer Financial Protection Bureau in the United States (Hastings et al., 2013). See also Gine et al. (2014) and Fort et al. (2016) for studies on the influence of bank financial information disclosure a practice which may be regulated by authorities.
} 
improve their financial health.

In this paper, we estimate the impact of a tablet-based application that incorporated simplified, concrete, targeted, timely, engaging, and interactive content on savings and budgeting via a delivery method that relied on local community leaders to rotate the tablets among mostly female recipients of Más Familias en Acción, a conditional cash transfer (CCT) program in Colombia 3 As the evaluation sample is followed over time and the survey data are linked to bank administrative and credit system records, we are able to track how the intervention's impacts on a variety of outcomes change over time. The data's richness allows us to interpret the observed effects and their evolution.

Our results show that the intervention had significant positive impacts on financial knowledge, attitudes, practices, and performance, translating into increased financial health 25 months after the end of the intervention. Although the impacts on certain outcomes were stronger immediately following and seven months after the intervention ended, for a subset of outcomes we find persistent positive impacts. For a few outcomes, the impacts observed 25 months after the intervention are actually higher than those observed at just following it. Initially, women who received the LISTA tablets demonstrated better understanding of savings and budgeting concepts, expressed stronger preferences for saving formally rather than informally, reported more trust in banks, and professed more optimism in general. LISTA participants were also more likely to set savings goals, felt more capable of teaching others how to use ATMs, and reported more informal savings. These results, based on self-report, are mirrored in administrative bank data, which also indicated higher savings account balances three months after the intervention. Seven months after the intervention, many of the impacts held but with smaller magnitudes. When measured 25 months after the intervention concluded, the impact on knowledge, attitudes, and practices waned and even disappeared in some cases, yet the impact on savings strengthened while the use of formal credit, based on credit history administrative data, decreased.

We also observe some heterogeneity in the impacts. In general, estimated impacts are larger for poorer, less educated, younger, and more rural populations. These heterogeneous patterns seen over time are consistent with a story that explains the intervention's effects as resulting from providing important information to the households that needed it most.

The remainder of the paper is organized as follows. Section 2 situates the study within the existing evidence-base on what works or could work within financial education programs and introduces the policy context, target population, and tablet program. Sections 3 and 4 outline the experimental design and empirical strategy. Section 5 presents the main results before exploring heterogeneous effects and possible mechanisms in section 6. Section 7 concludes.

\section{Financial Education and the LISTA Program}

Effective financial intermediation via formal or informal savings, credit or insurance markets is crucial for any household, be they a suburban home in the United States or semi-subsistence

\footnotetext{
${ }^{3}$ Although the MFA program targets women, there are a minority of male beneficiaries. In our study sample, 91 percent were female.
} 
families in the Peruvian Amazon. Access to and the ability to operate efficiently in such markets is especially critical for lower-income families, who struggle to match volatile and unpredictable income streams with volatile and unpredictable spending needs (Collins et al., 2009). Yet enabling for smoothing and overcoming shocks to current income in order to ensure survival is only part of the task of public policy and welfare systems. To escape poverty and vulnerability, poor households also face the challenge of accumulating savings to invest in human or business capital, with the hope of increasing income over the long-term. Financing these investments requires good understanding of the importance of saving and financial access. If lower-income households can access and navigate comfortably financial systems that smooth income and consumption, protect them against shocks, and enable investment, then they may be considered as financially healthy (CSFI, 2017).

Since credit and insurance markets are often imperfect or inaccessible for poor households (Karlan and Morduch, 2010; Morduch, 1995), savings mobilization may be perceived as the most viable option for creating financial health. Regardless, supply-side barriers to savings remain, given account opening or maintenance fees, transportation costs, inconvenience, or poorly designed products, which fail to take into account client needs or behavioral biases. Demand-side barriers to savings include decision biases as well as a lack of consumer information, knowledge, attitudes, preferences, and skills, all of which may affect the adoption of formal or informal savings practices and hinder usage following take-up (Karlan et al., 2014).

The LISTA para Ahorrar or "Ready to Save" program was created with the premise that generating savings was the most effective tool for supporting poor households in Latin America. Designed by Fundación Capital, the intervention grew out of a regional initiative, Proyecto Capital, which sought to leverage Latin America's conditional cash transfer (CCT) infrastructure by combining automatic opening of bank accounts (supply) with financial education (demand) to promote savings. 4 Proyecto Capital emerged in the mid-2000s amid the movement towards delivery of cash transfers via bank accounts and wariness of microcredit approaches to poverty reduction. At that time, Latin American governments had created and expanded CCT programs focusing on education and child health, with evidence of impact 5 Meanwhile, mixed evidence of microcredit's impact started to appear (Morduch and Roodman, 2014, Banerjee et al., 2015). Some argued that microcredit might be more beneficial for people living above the extreme poverty threshold, while CCT programs were better suited for the financially vulnerable (Pantelić, 2011). In parallel, Fundación Capital's founders gained experience with a rural women's savings programs in the Peruvian Andes (FIDA, 2004b a; Edge Finance, 2007). This confluence led to the founding of Proyecto Capital $\mathrm{f}^{6}$

A central challenge for Fundación Capital was how to leverage the CCT infrastructure to offer impactful, cost-effective financial education at scale. The organization concluded that any solution

\footnotetext{
${ }^{4}$ For more information on Fundación Capital and its programs, see https://fundacioncapital.org/.

${ }^{5}$ For Mexico see Gertler (2004); for Colombia see Attanasio and Mesnard (2006); for an early review in Latin America see Handa and Davis (2006); for a systematic global review see Bastagli et al. (2016).

${ }^{6}$ Funded by the Ford Foundation and IDRC, the initiative rested on the argument that increased savings would help users smooth consumption, buffer against shocks, and invest in human and productive capital, while the targeting of women was seen as the most effective way to improve resource use and break the household reproduction of poverty (Duflo, 2012, Almås et al. 2018). See Maldonado 2018) for reflections on the program's learnings.
} 
required moving away from traditional, in-person interventions, which called for a physical space, skilled instructors, and printed materials (Cohen and Nelson, 2011), and risked low participation rates since beneficiaries incur transportation and opportunity costs to attend multiple sessions (e.g., Seshan and Yang, 2012).

Fundación Capital sought to "free" financial education via a tablet-based application guided by three principles: tablet use would not require the physical presence of a trainer since the pupil would bring the teacher (the tablet) into the home; users could work through the content at their own pace; and tablet use may foster content customization since people could focus on topics most relevant to them. Piloting began in Colombia in 2012, with a second version tested in 2014. The result was an evidence-based intervention which incorporated simplified, actionable, concrete, targeted, timely, engaging, and interactive content via a delivery method that relied on a network of local female community leaders, a trusted channel which could activate social learning.

LISTA's approach and original content was developed from the lessons learned in a variety of contexts. Although traditional financial education programs often provide broad theoretical content, concrete, simplified and focused messages are better retained and more actionable (e.g., Soman and Zhao, 2011, Ülkümen and Cheema, 2011). A randomized evaluation in the Dominican Republic, for example, revealed that the teaching of rules of thumb to micro-entrepreneurs not only made the tips easier to remember but spurred action, resulting in differences in practices and revenues compared to a control and traditional education treatment (Drexler et al., 2014).

Meta-analysis also suggests that financial education has more impact in domains where people have greater control, such as budgeting and savings, with less impact in areas contingent on the decisions of other actors, such as loan default (Miller et al., 2015). Furthermore, since omitted psychometric variables such as self-efficacy and self-control may relate to improved outcomes Hsiaw, 2013), more explicit focus on these elements may complement traditional content (Fernandes et al., 2014). For example, a focus on goal-setting, which affects self-control, has proven effective for encouraging savings (Carpena et al., 2017; Soman and Zhao, 2011; Ülkümen and Cheema, 2011).

Content conveyed via emotions and stories are better remembered and acted upon. Laboratory experiments find that fear makes people more risk-averse and anger spurs more risk seeking (Lerner and Keltner, 2001), while sadness creates a myopic focus (Lerner et al., 2013) and fosters more consumption (Garg and Lerner, 2013). For example, conveying disgust and sadness via film clips has led to differential buying and selling decisions in laboratory settings (Lerner et al. 2004 ). Likewise, stories are intimately linked to memory and action (e.g., Tulving, 2002, for episodic memory). Exposure to soap operas which use emotionally-laden storytelling techniques has had effects on divorce (Chong and Ferrara, 2009) and fertility rates (La Ferrara et al., 2012). Finally, the seeding of financial education content in a South African soap opera increased financial knowledge and shifted borrowing and credit-use habits (Berg and Zia, 2017). Given message recall, the authors hypothesize that the story-driven emotional connection was critical for generating impact.

Content is also made more engaging via practice and interaction, such as gamification, which taps into distinct learning pathways, i.e., learning by doing or experiential learning (Kolb, 2014). 
Games may be particularly useful in low-literacy contexts as an alternative learning channel, though to our knowledge the field still lacks rigorous evidence of gamification's impact.

Finally, timing matters. First, information or reminders that are made just-in-time when people are about to make decisions have a greater likelihood of impact (Karlan et al., 2016b). Second, longer and more intense programs may improve results (Miller et al., 2015; Kaiser and Menkhoff, 2017; Lusardi et al., 2017), but there is a trade-off. Programs with longer duration can increase costs and attrition.

In sum, simplified, actionable, concrete, targeted, and timely content that taps into emotions and stories may be more effective, and both, like gamification, are more engaging and thus more motivating for users. Together these components may enhance retention while spurring behavior. The LISTA tablet-based application incorporated these insights. Repeated testing resulted in simplified content with a focus on savings and budget management, as well as information on the participating bank and the CCT program (see Appendix A). Simple, concrete, and actionable goal-focused messages were developed and reinforced by integrating audio, inspirational testimonial videos, educational games, and interactive ATM and mobile banking simulators. The use of multiple media sought to overcome literacy barriers and provide an entertaining educational experience, while empowering users through messaging and technology use. With tablet access, users could review the content as much or little as they wanted within a time frame. Since the application did not require Internet access, it was readily accessible even in remote rural areas. Finally, after the tablet intervention, SMS nudge messages were timed to be sent just before and after the MFA program's bi-monthly cash transfers.

But the impact of even well-designed content will be blunted if not delivered well. The degree of trust that the receiver has of the messenger is critical for the attention given to the message (Pornpitakpan, 2006). In financial education, the trust users have in a program or its channels (i.e., radio, television, SMS) may affect both take-up and perception of the program's utility. Social learning interventions also serve as a kind of channel in their ability to amplify messages via peers and networks (Duflo and Saez, 2003: Beshears et al., 2015). In other contexts the use of "near-peers" have been useful for mentoring in secondary and higher education settings since pupils identify more with the near-peer, are more likely to trust the shared information, and are communicated to in a register that pupils better understand (Bulte et al., 2007; Terrion and Leonard, 2007).

To reach as many people as possible in Colombia, Fundación Capital experimented with several implementation strategies, before selecting a rotation approach. In Colombia, as in other contexts, the CCT beneficiaries, which include the 20 percent poorest households, elect a representative as a local leader and spokesperson for the program. As the cash transfers are targeted predominantly to women, in Colombia these representatives are called madre lideres or "mother leaders." 7 These local representatives are responsible for communicating MFA program information to, on average, the 20 to 80 women they represent. Furthermore, the madre lider organizes periodic meetings of the program beneficiaries, where a number of activities are planned. This infrastructure had

\footnotetext{
${ }^{7}$ In Mexico they are known as vocales or promotoras.
} 
already been used to deliver successfully other interventions such as home visiting programs for early childhood development, as discussed in Attanasio et al. (2014), who report that the madres líderes are typically better educated and generally better off than the average beneficiary.

Fundación Capital thus decided to use this infrastructure to deliver the intervention. The tablet was thus rotated for a month by madres lideres among beneficiary mothers within their group, either by visiting their homes and leaving the tablet for one or two nights and/or by convening mothers to their homes or community centers where they completed the tablet training in groups. After one month, a facilitator retrieved the tablet and rotated it with a new madre lider in the municipality. On average, madres líderes reached 20 mothers per month. For the LISTA para Ahorrar program, tablets were distributed to madres lideres in 30 municipalities, reaching 100,000 program beneficiaries. The intervention was also combined with distribution of a physical LISTA kit, which included calendars with stickers to create a savings plan and simplified accounting books, both of which sought to scaffold new behavior. Finally, 14 SMS messages were sent to a subset of the tablet recipients over a four-month period after the tablet intervention, with the goal of reinforcing knowledge and reminding users to save (see section 9 in the Supplementary Material document).

\section{Experimental Design}

The experimental design estimates the impact that the LISTA treatment has on financial knowl-

edge, attitudes, practice adoption, and performance relative to a control group. To estimate these impacts we designed a cluster randomised controlled trial, where the randomization was performed across a number of municipalities. The experiment's cluster design avoids spillover effects between treated and untreated madres líderes which could have biased the estimates of the impacts. As a municipality is randomized either into treatment or control groups, subjects in the latter cannot be affected by the program being implemented with beneficiaries they know.

\subsection{Municipality Selection}

Municipalities were selected based on government and research criteria. Prosperidad Social, the government entity responsible for the Más Familias en Acción (MFA) program, wanted to target the most vulnerable population. Eligible municipalities therefore needed to be category 3 or 4 , according to Colombian state law, which meant that they were medium or small in population and budget size. The municipality's Multidimensional Poverty Index needed to be greater than 66.5 percent, ensuring that the average target population in the municipality was "vulnerable" compared to the national average of 24.8 percent. At least 2,600 MFA beneficiaries needed to live in each municipality, permitting the program to reach 100,000 beneficiaries. At least one active bank or ATM machine needed to exist in the municipality, providing the population with at least minimal access to the formal financial system, though participants in remote areas may have still had difficulties accessing these financial channels. No other government-related financial education 
programs could be active in the municipality. Finally, municipalities needed to be geographically proximate to minimize operational costs. Sixty municipalities distributed among eight departments in Colombia's two poorest regions, the Caribbean and Pacific, met these criteria (see Appendix B) 8

To ensure covariate balance among the treatment and control municipalities, randomization blocks were created based on region (Caribbean or Pacific), average poverty marker or SISBEN points 9 at the municipality level, and distance to closest department capital. Block randomization helped account for economic vulnerability, access to financial markets, and geography, with the latter also proxying for sub-national cultural differences. A $2 \times 2 \times 2$ stratification was created; within each, municipalities were randomized into control and treatment. 10

\subsection{Beneficiary Selection}

We developed a strategy to identify the beneficiaries most likely to receive the tablet in the control and treatment municipalities. Several elements were considered: LISTA was a voluntary program offered to madres lideres of a group of existing MFA beneficiaries, the selected sample had to be statistically identical between control and treatment municipalities, and baseline surveys had to occur before the intervention. Given the role madres líderes played in the final selection of LISTA users, we created a list of the beneficiaries most likely to be selected by the madres lideres.

MFA beneficiaries are organized into groups ranging from on average 20 to 80 , with each led by a madre líder. Based on pilots of the LISTA rotation methodology, one tablet was estimated to reach 20 and 30 beneficiaries. Given this, 11 madres líderes per municipality were randomly selected and contacted. They were asked to identify 18 to 21 beneficiaries in their group who they would consider approaching to participate in a generic financial training program. From those identified beneficiaries, four to six were randomly selected and surveyed at baseline, with the expectation of some sample attrition, especially during the first approximation. Since data indicated whether the madres líderes were in rural or urban environments, a representative selection of madres lideres was ensured. Overall, 615 madres líderes were contacted and 13,216 individual beneficiaries were identified, with 3,136 CCT recipients surveyed as part of the baseline survey.

\footnotetext{
${ }^{8}$ The Colombian government contracts with two banks, Banco Agrario and Davivienda, to open and make transfers into accounts. At the time, Banco Agrario served the largest number of MFA beneficiaries, mostly because it had better coverage in smaller and more remote municipalities. Of the 60 municipalities identified for randomization, 54 were served by Banco Agrario and six by Davivienda. MFA beneficiaries have the option of withdrawing the transfers via an ATM, while Davivienda offered mobile banking services. The LISTA tablet provided information for both withdrawal types, depending on the account specified by the beneficiary.

${ }^{9}$ The SISBEN is an information system used by the Colombian National Government to determine eligible beneficiaries of social programs, such as the Más Familas en Acción CCT program.

${ }^{10}$ Upon completion of the LISTA implementation five months after baseline, a second randomization was performed for the SMS nudge message treatment. This required a cluster randomization at the mother leader level, in order to prevent spillover between recipients with the same mother leader from biasing estimates. Only those mother leaders whose recipients reported receiving the tablet were included in the randomization. Randomization blocks were constructed according to the average number of MFA beneficiaries per leader in order to ensure sample size balance.
} 


\subsection{Sample Characteristics}

Ninety-one percent of the sample was female, averaging 39 years of age at baseline (SD 10.34 years, minimum age 18.55, maximum age 83.58). Fifty-one percent lived in rural areas, which was higher than the national average of 24 percent. Nearly 10 percent of the sample considered themselves indigenous, over double the 4 percent national average. These characteristics reflected the government's goal of targeting Colombia's most vulnerable communities. However, the proportion of the population living in rural areas varied by department and region. Forty percent of the Caribbean and 75 percent of the Pacific regions were rural. Sixty-eight percent of the total sample lived in the Caribbean, with 32 percent from the Pacific.

Sampled households averaged five members, with two younger than 18 and less than one (0.4) considered a senior citizen. Over half of the beneficiaries practiced Catholicism; 19 percent were married, while 58 percent co-habitated or lived in free union; 54 percent owned their home; and 53 percent lived in houses with cement or gravel floors. Overall, 46 percent had primary education and 41 percent reached secondary schooling. The average number of people working per household (either formally or informally) was 1.4. In 14 percent of the households, nobody worked or received monetary remuneration for labor activities in a designated period of time prior to the baseline survey, though this may have been due to the cyclical nature of remunerated work in rural areas. Reported expenditures were relatively homogeneous, with spending increasing less than proportionally with each additional household member. Most of the sample households (87 percent) spent weekly between 50,000 and 150,000 Colombian pesos (COP) or approximately US $\$ 2.55$ to US\$ 7.65 per day.

\section{Empirical Strategy}

This section describes our estimation approach. We start with a discussion of the empirical specifications estimated. We then describe the data used and the balance between the treatment and control sample prior to the program. Finally, we discuss attrition.

\subsection{Estimation Approach}

This paper evaluates the short-, medium-, and long-term impact of the LISTA tablet intervention on financial attitudes, knowledge, practices, performance, and psychosocial indicators. The cluster randomized controlled trial we designed allows us to estimate these effects, comparing the outcomes of interest between MFA beneficiaries in tablet treatment versus control municipalities 11

Our analysis presents intention-to-treat (ITT) impacts, that is, comparison of the means of those assigned to receive LISTA with those in the control group. In other words, all beneficiaries living in municipalities randomly assigned to the treatment group are considered as treated, independently of whether they actually received the tablet. Based on self-reported and telemetric data, 77.5

\footnotetext{
${ }^{11}$ For the SMS treatment, the evaluation compared LISTA tablet beneficiaries who received SMS messages vs. LISTA tablet beneficiaries who did not.
} 
percent of people surveyed reported receiving the LISTA tablet. We also compared the people who effectively received LISTA to the control group by instrumenting actual use of the tablets with a dummy indicating whether or not the beneficiary was randomized into the treatment group 12

We focus on the ITT analysis to avoid issues that could arise from possible self-selection effects within the treatment group. An additional advantage of this more conservative approach is we can interpret the experimental intervention as a policy, in the sense that we estimate impact for targeted beneficiaries of the program and not just those who used the LISTA tablet. For the remainder of this article, the term "the impact of LISTA" refers to the ITT estimation.

The core regression framework used for the estimation was:

$$
Y_{i m}=\beta_{0}+\beta_{1} T_{i m}+\beta_{x} X_{i}+\epsilon_{i}
$$

Where $\beta_{1}$ measures the impact of LISTA, and $Y_{i m}$ is the outcome variable of interest for individual $i$ in municipality $m$. Whether a beneficiary was assigned to receive a tablet is determined by $T_{i m}$. $X_{i m}$ is a set of characteristics of the respondents at the baseline and includes both demographic and outcome variables. When available, we condition on the baseline level of the outcome variable to improve statistical power (McKenzie, 2012, McConnell and Vera-Hernández, 2015). Finally, $\epsilon_{i}$ is the error term. To compute standard errors, we cluster the residuals at the municipality level $\left[{ }^{13}\right.$

\subsection{Data}

Data included four survey rounds plus administrative data from the government, two banks, and credit records $\sqrt{14}$ Baseline data were collected after the randomization and sample definition, but prior to the intervention. These data were used to check for balance and as control variables in subsequent analysis. A specialized survey firm working under the research team's supervision conducted a phone survey baseline in late April and early May 2015.

Data for the first follow-up survey were gathered after the LISTA implementation and enabled a short-term measurement of impact five months after baseline, just following the end of the tablet intervention (see Appendix C). The first follow-up data collection was performed via the Prosperidad Social call center, under the research team's guidance and supervision in late September and early October 2015. The second follow-up survey data were collected in person by the same survey firm 7 months after the tablet treatment ended, in April and May 2016 and also under the research team's supervision. A third follow-up survey was conducted over the phone 25 months after the intervention ended. The same firm as that which conducted the baseline and second follow-up

\footnotetext{
${ }^{12}$ This Treatment-on-the-Treated (ToT) analysis provided similar results to the ITT findings, though with slightly higher magnitudes, as expected. Results are available in section 6 of the Supplemental Materials document.

${ }^{13}$ We measured the impact of SMS messages by comparing SMS recipients vs. tablet-only recipients. To estimate the effect of the SMS treatment in the second and third follow-ups, we control for the baseline and first follow-up, since the SMS intervention began after the first follow-up. We added a dummy variable $d_{i m}$, to account for missing data from the first follow-up survey (equal to 1 for missing values and 0 otherwise), thus dummying out the missing data and preserving the full sample found at the second and third follow-ups.

${ }^{14}$ These data were obtained via agreements with the Department of Social Prosperity and, later, the Central Bank of Colombia, who granted data access while co-author Lina Cardona worked in the latter entity.
} 
survey collected the data under the research team's supervision in November 2017.

Survey data were complemented with administrative and demographic data provided by Prosperidad Social (e.g. the SISBEN points and household composition). Prosperidad Social also facilitated access to anonymous bank data through December 2015. Finally, the Colombian financial superintendency enabled access to credit system data through December 2017. Measurement focused on five classes of outcomes: financial attitudes, financial knowledge, financial practices, financial performance, and psychosocial indicators.

To measure the effect of the tablet on financial performance, we use two different sources of administrative information. First, we estimate the effect of the tablet intervention on formal savings and transactionality or frequency of use of formal financial services using bank administrative data (from May to December 2015) following an ANCOVA specification for each two-month moving average. Due to data privacy laws in Colombia, we were unable to match survey data with the bank administrative data. We standardized average savings using the mean and variance from January 2014 data. Controls for this estimation include having an account with Banco Agrario (vs. Davivienda), two-month average monthly savings between January 2014 and April 2015, the number of financial institutions in the municipal district, randomization blocks, and a set of municipal-level socioeconomic covariates.

We estimate the impact of LISTA on credit and debt following the regression specification in equation (1), using credit system data between the third quarter of 2015 until the end of 2017. While the bank data was anonymous and we were not able to match the individual observations with our survey data, we were able to match individual observations with credit records from the Central Bank of Colombia. Credit records data contain indicators about the type of consumer credit (i.e., whether it is a standard loan or a credit card), the institution that provided the credit, outstanding debt amount, the number of default days, among others. Between 2004 and 2017, 10 percent of the sample were found at least once in the dataset, i.e., having at least one credit.

\subsection{Treatment-Control Balance}

The baseline survey collected data over the phone for 3,136 individuals, 1,567 of which were in the treatment. For the first follow-up, a sub-sample of 2,526 beneficiaries was administered the survey over the phone, with 1,267 in the treatment. For the second follow-up, 2,327 people were surveyed in person, with 1,172 in the treatment. Finally, for the third follow-up, 2,202 people were surveyed over the phone, with 1,096 in the treatment.

Table 2 compares the control and treatment groups on a subset of baseline measures. Respondents in both groups were statistically identical in terms of household characteristics, savings, MFA, and ATM practices. Only one of 36 demographic and outcome variables measured at baseline was significant. 
Table 1: Variable Description

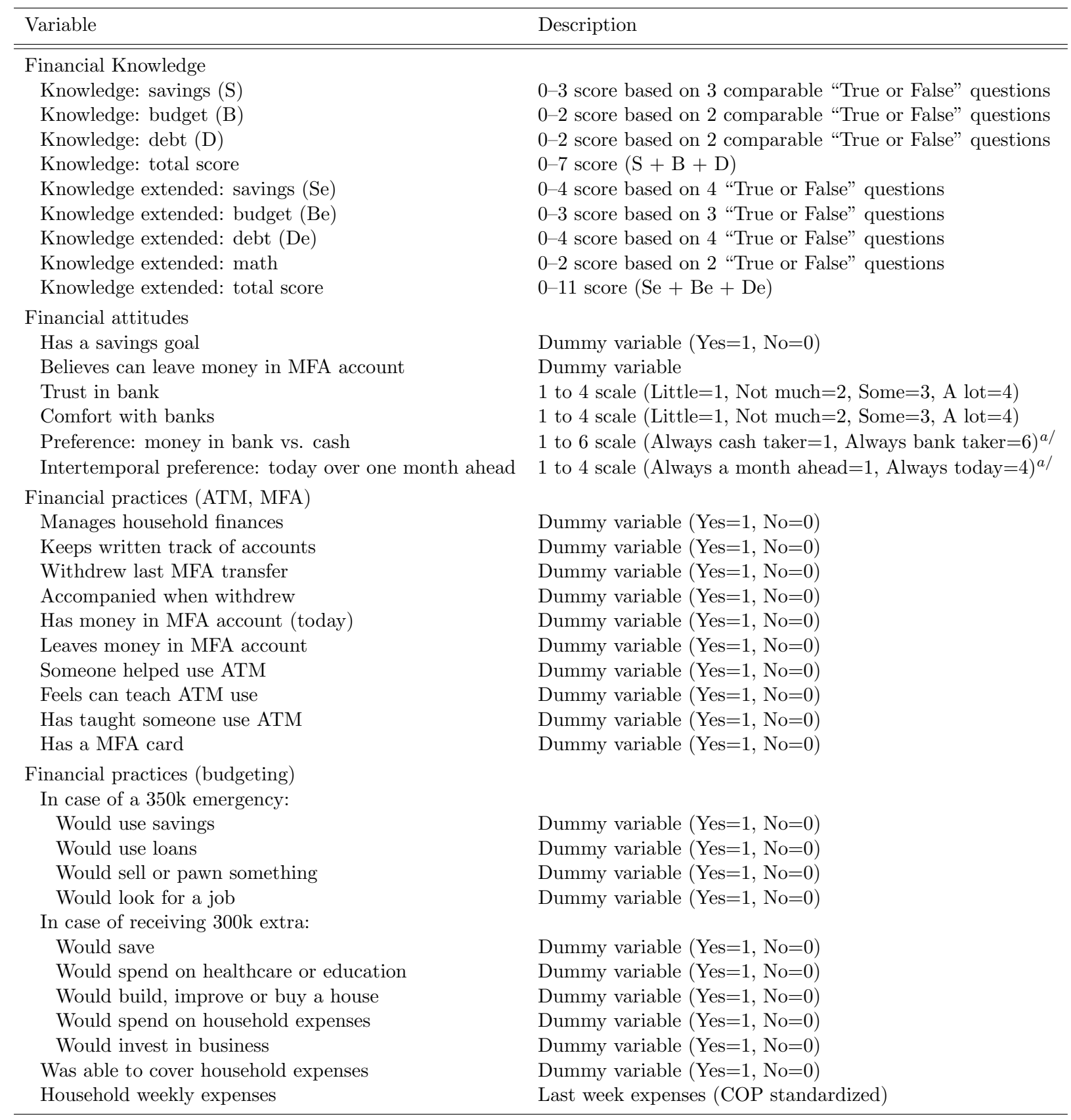

a/ Own construction based on a set of two alternatives questions. 


\section{Table 1: Variable Description (continued)}

\begin{tabular}{|c|c|}
\hline Variable & Description \\
\hline \multicolumn{2}{|l|}{ Financial practices (savings) } \\
\hline Formal or informal savings & Dummy variable $(\mathrm{Yes}=1, \mathrm{No}=0)$ \\
\hline Formal savings: bank or cooperative & Dummy variable $(\mathrm{Yes}=1, \mathrm{No}=0)$ \\
\hline Informal savings: piggy bank or other places & Dummy variable $(\mathrm{Yes}=1, \mathrm{No}=0)$ \\
\hline Save money in piggy bank & Dummy variable $\left(\mathrm{Yes}=1, \mathrm{No}_{0}=0\right)$ \\
\hline Save money in bank account & Dummy variable $(\mathrm{Yes}=1, \mathrm{No}=0)$ \\
\hline \multicolumn{2}{|l|}{ Financial Performance (self-reported) } \\
\hline Total amount of formal and informal savings & Sum of formal and informal savings (COP standardized) \\
\hline Total amount of formal savings & Sum of savings in bank and cooperative (COP standardized) \\
\hline Total informal savings & Sum of savings in piggy bank and other places (COP standardized) \\
\hline Amount of savings in piggy bank & In COP standardized \\
\hline Amount of savings in a bank & In COP standardized \\
\hline \multicolumn{2}{|c|}{ Financial performance (savings) - Administrative data } \\
\hline Two-month moving averages & In Colombian Pesos standardized \\
\hline \multicolumn{2}{|c|}{ Financial Performance (credit) - Administrative data } \\
\hline Credit & Dummy variable $(\mathrm{Yes}=1, \mathrm{No}=0)$ \\
\hline Consumption credit & Dummy variable $(\mathrm{Yes}=1, \mathrm{No}=0)$ \\
\hline Credit with banks & Dummy variable $(\mathrm{Yes}=1, \mathrm{No}=0)$ \\
\hline Credit card & Dummy variable $(\mathrm{Yes}=1, \mathrm{No}=0)$ \\
\hline Default & Dummy variable $($ Yes $=1, \mathrm{No}=0)$ \\
\hline Max. default days & Maximum number of days in default per year \\
\hline Amount of debt & In Colombian Pesos, standardized \\
\hline Credit card debt & In Colombian Pesos, standardized \\
\hline Consumption credit debt & In Colombian Pesos, standardized \\
\hline Average number of credits & Number of credits per year \\
\hline \multicolumn{2}{|l|}{ Psychosocial Indicators } \\
\hline Optimism & 1 to 7 scale $(1=$ Not at all optimistic, $7=$ Very optimistic $)$ \\
\hline Pessimism & 1 to 7 scale $(1=$ Not at all pessimistic, $7=$ Very pessimistic $)$ \\
\hline People trust & Dummy variable (Believes people are trustworthy $=1$ ) \\
\hline More trustworthy of other people & 1 to 4 scale (Can trust a little in other people $=1$, Can trust a lot $=1$ ) \\
\hline Interested in savings program & 1 to 4 scale (Little interested $=1, \mathrm{~A}$ lot $=4$ ) \\
\hline There are lots of ways around any problem & 1 to 7 scale $($ Completely disagree $=1$, Completely agree $=7$ ) \\
\hline Is meeting her goals & 1 to 7 scale (Completely disagree $=1$, Completely agree $=7$ ) \\
\hline Self-efficacy & 1 to 4 scale (Low self-efficacy $=1$, High self-efficacy $=4)^{b /}$ \\
\hline Future orientation & 1 to 4 scale (Low future orientation $=1, \mathrm{High}=4)^{b /}$ \\
\hline Social capital & 1 to 3 scale (Low social capital $=1$, High $=3)^{c /}$ \\
\hline
\end{tabular}

$b /$ Own construction based on three 1 to 4 scale questions.

$c /$ Own construction based on three "Yes/No" questions. 


\subsection{Attrition}

For the first follow-up survey, 81 percent of the baseline respondents were successfully re-interviewed. Response rates for the second and third follow-ups were 74 and 70 percent of baseline respondents, respectively. This attrition was due in large part to budget constraints which prevented surveying the entire sample at each follow-up, allowing for data collection of 2,500 subjects for the first follow-up and 2,300 for the second follow-up. An attempt was made to reach 2,500 subjects for the third follow-up but due mostly to disconnected cellular numbers, 2,202 surveys were completed for the third follow-up. It is important to note that 2,983 people (95 percent of the sample) were surveyed at least once after baseline, as part of the first, second or third follow-up surveys.

To assess the possible impact of sample attrition, a balance analysis was performed for each survey round. We estimate the probability of attrition as a function of a treatment dummy and a range of respondent and household characteristics, controlling for randomization blocks. Results indicate no significant difference between attrition levels in the control and treatment groups. Some covariate controls did correlate at different moments with the probability of attrition in the first, second and third follow-up surveys. At separate points, the probability of attrition was negatively correlated with age, years of schooling, whether the beneficiary belongs to an urban district, and whether the beneficiary receives money via account deposits. Having an account with Banco Agrario, which had a greater ratio of clients in rural areas, was also positively related to attrition status. In other words, younger, rural, and less educated individuals were harder to reach in general in the follow-up surveys, regardless of whether they were conducted over the phone or in person. In sum, the analysis suggests that treatment was not related to attrition status. Some variables, in particular, years of schooling, area (urban or rural) and type of bank account (deposit or wire transfer), may be correlated with respondent attrition. Yet the effect of this attrition on results is marginal at most. The analysis presented in this section considers attrition between the baseline and the first, second, and third follow-ups, with only 5 percent of the sample not

re-interviewed at all in the follow-up surveys. Also, the coefficients and significances detected in estimations with and without control are highly similar, suggesting that the attrition effect (if present) does not represent a major threat to the validity of results. Regardless, we present results for the intervention with controls for those characteristics. (See section 5 of the Supplemental Material for estimates without controls.) 
Table 2: Baseline Balance Checks

\begin{tabular}{|c|c|c|c|c|c|c|}
\hline & \multirow[b]{3}{*}{ Obs } & \multirow{2}{*}{\multicolumn{3}{|c|}{ Control }} & \multicolumn{2}{|c|}{ Treatment group } \\
\hline & & & & & $-\mathrm{Cc}$ & trol \\
\hline & & Obs & Mean & SD & Coeff. & $p$-value \\
\hline \multicolumn{7}{|l|}{ Household characteristics } \\
\hline Education level & 3,127 & 1,569 & 3.572 & 0.897 & -0.044 & 0.394 \\
\hline Years of education & 3,127 & 1,569 & 9.723 & 4.311 & -0.167 & 0.487 \\
\hline Members per household & 3,126 & 1,569 & 5.224 & 1.976 & -0.046 & 0.664 \\
\hline Children per household & 3,126 & 1,569 & 2.357 & 1.267 & -0.005 & 0.939 \\
\hline Worker in the household ${ }^{1 /}$ & 3,127 & 1,569 & 0.874 & 0.331 & -0.032 & 0.373 \\
\hline Workers per household & 3,127 & 1,569 & 1.467 & 1.015 & -0.074 & 0.340 \\
\hline Urban $^{1 /}$ & 3,119 & 1,566 & 0.486 & 0.500 & 0.015 & 0.796 \\
\hline \multicolumn{7}{|l|}{ Más Familias en Acción } \\
\hline Withdrawal accompanied ${ }^{1 /}$ & 2,556 & 1,260 & 0.404 & 0.491 & 0.036 & 0.144 \\
\hline ATM withdrawal $^{1 /}$ & 2,553 & 1,260 & 0.710 & 0.453 & 0.054 & 0.201 \\
\hline $\mathrm{ATM} \mathrm{use}^{1 /}$ & 2,923 & 1,461 & 0.444 & 0.497 & 0.047 & 0.241 \\
\hline Believes can teach ATM use ${ }^{1 /}$ & 1,392 & 664 & 1.303 & 0.936 & 0.011 & 0.874 \\
\hline Believes can leave money in account ${ }^{1 /}$ & 2,514 & 1,264 & 0.584 & 0.493 & 0.014 & 0.618 \\
\hline Money left in account ${ }^{1 /}$ & 2,047 & 1,009 & 0.525 & 0.500 & 0.021 & 0.493 \\
\hline \multicolumn{7}{|l|}{ Budget } \\
\hline Budget control ${ }^{1 /}$ & 3,125 & 1,568 & 1.496 & 0.774 & -0.012 & 0.680 \\
\hline Written budget $^{1 /}$ & 2,566 & 1,289 & 0.221 & 0.414 & -0.005 & 0.794 \\
\hline Budget income and expenses written ${ }^{1 /}$ & 561 & 283 & 0.770 & 0.421 & -0.044 & 0.185 \\
\hline Last week expenses & 2,869 & 1,421 & -0.009 & 0.966 & 0.012 & 0.855 \\
\hline Savings for $100 \mathrm{k}$ COP emergency ${ }^{1 /}$ & 3,092 & 1,551 & 0.281 & 0.449 & 0.029 & 0.145 \\
\hline Loans for 100k COP emergency ${ }^{1 /}$ & 3,092 & 1,551 & 0.655 & 0.476 & -0.018 & 0.410 \\
\hline Other for 100k COP emergency ${ }^{1 /}$ & 3,092 & 1,551 & 0.064 & 0.248 & -0.011 & 0.310 \\
\hline Was able to cover household expenses ${ }^{1 /}$ & 3,119 & 1,567 & 2.804 & 0.858 & 0.013 & 0.643 \\
\hline Has applied for loan from bank ${ }^{1 /}$ & 3,126 & 1,569 & 0.307 & 0.461 & 0.021 & 0.365 \\
\hline Loan from bank approved ${ }^{1 /}$ & 989 & 481 & 0.877 & 0.331 & 0.014 & 0.534 \\
\hline \multicolumn{7}{|l|}{ Savings } \\
\hline Has savings goal ${ }^{1 /}$ & 3,122 & 1,566 & 0.461 & 0.499 & 0.035 & 0.166 \\
\hline Has savings in piggy bank ${ }^{1 /}$ & 3,122 & 1,566 & 0.413 & 0.492 & 0.026 & 0.284 \\
\hline Has informal savings ${ }^{1 /}$ & 3,126 & 1,568 & 0.418 & 0.493 & 0.023 & 0.335 \\
\hline Total informal savings (standardized) & 3,126 & 1,568 & 0.008 & 1.071 & -0.015 & 0.698 \\
\hline Has savings in bank account ${ }^{1 /}$ & 3,118 & 1,563 & 0.158 & 0.365 & -0.001 & 0.917 \\
\hline Has savings in cooperative ${ }^{1 /}$ & 3,126 & 1,568 & 0.024 & 0.154 & -0.009 & 0.114 \\
\hline Has formal savings ${ }^{1 /}$ & 3,127 & 1,569 & 0.184 & 0.387 & -0.007 & 0.642 \\
\hline Total formal savings (standardized) & 3,127 & 1,569 & 0.007 & 1.039 & -0.014 & 0.707 \\
\hline Total savings (standardized) & 3,127 & 1,569 & 0.006 & 1.031 & -0.012 & 0.751 \\
\hline \multicolumn{7}{|l|}{ Preferences } \\
\hline Money now vs. one month & 3,116 & 1,563 & 3.024 & 1.508 & 0.056 & 0.315 \\
\hline Money now vs. 7 months & 3,113 & 1,559 & 4.379 & 1.176 & 0.019 & 0.672 \\
\hline Money in cash vs. bank account & 3,114 & 1,561 & 2.980 & 2.089 & -0.029 & 0.744 \\
\hline Trust in banks & 2,734 & 1,367 & 2.337 & 1.164 & $0.144^{* *}$ & 0.020 \\
\hline
\end{tabular}

Note: This table presents the balance checks for the baseline survey. $1 /$ indicates a dichotomous variable. Coefficient compares the treatment and control groups, controlling for randomization blocks and clustering standard errors at the municipality level. 


\section{Results}

This section reports the main results ${ }^{15}$ The tablet telemetric data suggesst that an average user engaged with the application for three to four hours, though this does not account for the possibility that there were multiple users in the same beneficiary household 16 Following presentation of the main results in this section, we will examine heterogeneous effects and their links to possible mechanisms in order to understand how impacts were achieved despite what appears as a low intensity of treatment compared to traditional financial education programs.

We also test various individual hypotheses based on the unadjusted marginal p-values. This implies a potentially large probability that some of the true null hypotheses will be rejected. Following Romano and Wolf (2005), we use a stepwise multiple-testing procedure that asymptotically controls for the family-wise error rate. Most of the effects for the first follow-up survive this correction for multiple-hypothesis testing and remain significant. For the second and third follow-up, the results that hold after adjusting for the family-wise error rate are mostly related to financial knowledge, attitudes, and savings outcomes.

\subsection{Financial Knowledge and Attitudes}

Financial knowledge refers to acquisition of basic financial concepts and information about the CCT program. Financial attitudes relate to perceptions of the banking sector as well as intertemporal preferences for having money in cash or in a bank and for having money today or in the future. Results are reported as standardized effects in Tables 3 and 4 .

Financial knowledge. To assess the impact of LISTA on basic financial concepts, a "true or false" test was administered in the three follow-up surveys. It included three sections: savings, budgeting, and debt. Questions were based on the tablet curriculum although the tablet content focused less on debt. For the second and third follow-up, additional questions were included, with a new section for basic numeracy administered in-person for the second follow-up. The first follow-up test included 10 questions, while the second and third follow-up surveys had 14 and 11, respectively. Our first measure of financial knowledge is based on seven questions that were comparable between all of the surveys, with each correct answer accounting for one point on the total score (0 to 7). The extended measure included four additional questions, comparable between the second and third follow-up (0 to 11$)$.

The tablet content focused specifically on savings and budgeting with light mention of debt

\footnotetext{
${ }^{15}$ Results for the evaluation's SMS intervention are available in section 8 of the Supplemental Materials document. SMS messages had a positive medium-term impact on the acquisition of financial knowledge, due to increased understanding of savings, but limited effects in other areas. Over the longer-term, SMS recipients were less likely to save - and saved less - in a bank account compared to the tablet-only treatment group. While the reported informal savings when compared to the tablet-only treatment had a positive coefficient, it was not significant and it is difficult to conclude that the SMS treatment encouraged substitution between formal and informal savings. Given this, we report detailed results on the pooled treatment versus control in this paper.

${ }^{16}$ While it was straightforward to cross-reference tablet registrants with the survey database, it was not possible to determine which unmatched registrants were members of the beneficiary households.
} 
management only in relation to the previous two topics. Regardless, questions on debt (and numeracy for the second follow-up) were included to explore the possibility of ancillary learning. LISTA had a positive and significant short-, medium-, and long-term impact on the composite scores (Table 3). Overall scores for the treatment group were 0.20 standard deviations (sd) higher immediately following the intervention, $0.18 \mathrm{sd}$ higher seven months after the intervention, and 0.14 sd higher 25 months after the intervention compared to the control group for the basic test. Scores for the expanded test were 0.19 and 0.17 sd higher after treatment in the medium- and long-term, respectively.

Analysis revealed positive and significant short-, medium-, and long- term impact on savings and budget knowledge. For the reduced test, there was a positive short-, medium-, and long-term impact of $0.23,0.15$, and 0.13 sd for savings, respectively. For budget knowledge, the increases were $0.14,0.08$, and $0.14 \mathrm{sd}$, respectively. Results for the extended version of the test were even more robust, with medium- and long-term savings knowledge impacts of 0.16 and 0.14 sd and budget knowledge increases of 0.16 and 0.18 sd. Interestingly, while the savings knowledge impacts waned, the budget knowledge impacts appear to have strengthened over time. The latter may reflect the building of knowledge via practice.

Results for the reduced debt section lacked significance in the short-term, reached significance in the medium-term with $0.08 \mathrm{sd}$, and lost significance in the long-term. For the expanded debt knowledge section, results were not significant for the medium- or the long-term. As we will see, this may align with differences in uses of formal credit between the control and treatment groups 25 months after completing the intervention.

There was some indication of marginal impact on numeracy skills in the second follow-up survey, suggesting that practice may have increased acquisition of certain types of knowledge and skills, since LISTA did not directly address mathematical concepts. In other words, people who begin to manage their accounts may need to use more basic math, which in turn may have increased their performance on the basic numeracy questions. As will be seen below, results from rural areas appear to have driven this improvement. Unfortunately, given budget constraints an in-person survey could not be conducted for the third follow-up so long-term numeracy was not examined.

Financial Attitudes. The survey asked respondents to rate their trust and comfort with banks on a 1 to 4 scale. The treatment group increased the levels of trust by around $0.20 \mathrm{sd}$ both in the short- and medium-term, but this effect dissipated in the long-term. Similarly, there is a positive short-term effect on comfort with banks with a shift of $0.19 \mathrm{sd}$. While this effect is not significant in the medium-term, a marginal increase in comfort with banks is found in the long-term, though it was not robust to the multiple-hypothesis correction. In other words, right after the intervention, the treated beneficiaries reported feeling more comfortable going to banks, but after a few months the effect dissipated. One hypothesis is that the intervention succeeded in changing attitudes toward visiting a bank, but after additional experience testing this new perception, the beneficiary may have updated her attitude, returning to the level of comfort prior to the intervention. 
Table 3: Impact of LISTA on Financial Knowledge

\begin{tabular}{|c|c|c|c|c|c|c|c|c|c|}
\hline & \multicolumn{3}{|c|}{ First follow-up } & \multicolumn{3}{|c|}{ Second follow-up } & \multicolumn{3}{|c|}{ Third follow-up } \\
\hline & Obs & Control & Treatment & Obs & Control & Treatment & Obs & Control & Treatment \\
\hline Knowledge: total score & 2,502 & 5.120 & $\begin{array}{c}0.201^{* * *} \\
(0.033)\end{array}$ & 2,305 & 5.574 & $\begin{array}{c}0.177^{* * *} \\
(0.050)\end{array}$ & 2,180 & 5.325 & $\begin{array}{c}0.140 * * * \\
(0.045)\end{array}$ \\
\hline Knowledge: savings section & 2,502 & 2.110 & $\begin{array}{c}0.230 * * * \\
(0.035) \\
{[0.000]}\end{array}$ & 2,305 & 2.256 & $\begin{array}{c}0.153^{* * *} \\
(0.050) \\
{[0.007]}\end{array}$ & 2,180 & 2.059 & $\begin{array}{c}0.129 * * \\
(0.050) \\
{[0.021]}\end{array}$ \\
\hline Knowledge: budget section & 2,502 & 1.442 & $\begin{array}{c}0.144^{* * *} \\
(0.038) \\
{[0.000]}\end{array}$ & 2,305 & 1.602 & $\begin{array}{c}0.078^{*} \\
(0.045) \\
{[0.095]}\end{array}$ & 2,180 & 1.540 & $\begin{array}{c}0.143^{* * *} \\
(0.042) \\
{[0.003]}\end{array}$ \\
\hline Knowledge: debt section & 2,502 & 1.568 & $\begin{array}{c}-0.018 \\
(0.044) \\
{[0.680]}\end{array}$ & 2,305 & 1.716 & $\begin{array}{c}0.083^{* *} \\
(0.041) \\
{[0.092]}\end{array}$ & 2,180 & 1.726 & $\begin{array}{c}-0.033 \\
(0.042) \\
{[0.434]}\end{array}$ \\
\hline Knowledge extended: total score & & & & 2,305 & 8.639 & $\begin{array}{c}0.194^{* * *} \\
(0.055)\end{array}$ & 2,180 & 7.790 & $\begin{array}{c}0.173^{* * *} \\
(0.051)\end{array}$ \\
\hline Knowledge extended: savings & & & & 2,305 & 3.135 & $\begin{array}{c}0.162^{* * *} \\
(0.054) \\
{[0.009]}\end{array}$ & 2,180 & 2.908 & $\begin{array}{c}0.136^{* *} \\
(0.051) \\
{[0.016]}\end{array}$ \\
\hline Knowledge extended: budget & & & & 2,305 & 2.262 & $\begin{array}{c}0.157^{* * *} \\
(0.046) \\
{[0.003]}\end{array}$ & 2,180 & 1.971 & $\begin{array}{c}0.177^{* * *} \\
(0.049) \\
{[0.001]}\end{array}$ \\
\hline Knowledge extended: debt & & & & 2,305 & 3.242 & $\begin{array}{c}0.069 \\
(0.047) \\
{[0.143]}\end{array}$ & 2,180 & 2.911 & $\begin{array}{c}0.023 \\
(0.039) \\
{[0.554]}\end{array}$ \\
\hline Knowledge extended: math & & & & 2,305 & 1.623 & $\begin{array}{c}0.091^{*} \\
(0.047) \\
{[0.102]}\end{array}$ & & & \\
\hline
\end{tabular}

Notes: *** significant at $1 \%, * *$ significant at $5 \%, *$ significant at $10 \%$, based on $p$-values unadjusted for multiple-hypothesis testing. Clustered standard errors at the municipality level (in parenthesis). Romano-Wolf adjusted $p$-values (in square brackets). Regressions control for randomization blocks, individual and household characteristics (gender, age, number of member in the household,...) and bank characteristics. The control means column shows non-standardized values. 
Table 4: Impact of LISTA on Financial Attitudes

\begin{tabular}{|c|c|c|c|c|c|c|c|c|c|}
\hline & \multicolumn{3}{|c|}{ First follow-up } & \multicolumn{3}{|c|}{ Second follow-up } & \multicolumn{3}{|c|}{ Third follow-up } \\
\hline & Obs & Control & Treatment & Obs & Control & Treatment & Obs & Control & Treatment \\
\hline Has a savings goal & 1,716 & 0.368 & $\begin{array}{c}0.167^{* * *} \\
(0.028) \\
{[0.000]}\end{array}$ & 1,630 & 0.270 & $\begin{array}{c}0.093^{* * *} \\
(0.025) \\
{[0.000]}\end{array}$ & 1,558 & 0.280 & $\begin{array}{c}0.147^{* * *} \\
(0.026) \\
{[0.000]}\end{array}$ \\
\hline Believes can leave money in MFA account & 1,597 & 0.650 & $\begin{array}{c}0.121^{* * *} \\
(0.020) \\
{[0.000]}\end{array}$ & 1,405 & 0.685 & $\begin{array}{c}0.073^{* * *} \\
(0.023) \\
{[0.005]}\end{array}$ & 1,441 & 0.736 & $\begin{array}{c}0.054^{*} \\
(0.027) \\
{[0.166]}\end{array}$ \\
\hline Trust in bank & 1,749 & 2.727 & $\begin{array}{c}0.204^{* * *} \\
(0.046) \\
{[0.000]}\end{array}$ & 1,588 & 2.616 & $\begin{array}{c}0.203^{* * *} \\
(0.048) \\
{[0.000]}\end{array}$ & 1,528 & 2.604 & $\begin{array}{c}0.087^{*} \\
(0.046) \\
{[0.170]}\end{array}$ \\
\hline Comfort with banks & 1,720 & 2.356 & $\begin{array}{c}0.190^{* * *} \\
(0.046) \\
{[0.000]}\end{array}$ & 1,557 & 2.471 & $\begin{array}{c}0.023 \\
(0.052) \\
{[0.630]}\end{array}$ & 1,510 & 2.599 & $\begin{array}{c}0.092^{*} \\
(0.053) \\
{[0.174]}\end{array}$ \\
\hline Preference: money in bank vs. cash & 1,773 & 3.552 & $\begin{array}{c}0.156^{* * *} \\
(0.038) \\
{[0.000]}\end{array}$ & 1,624 & 2.734 & $\begin{array}{c}0.179^{* * *} \\
(0.045) \\
{[0.000]}\end{array}$ & 1,555 & 2.796 & $\begin{array}{c}0.191^{* * *} \\
(0.056) \\
{[0.003]}\end{array}$ \\
\hline Intertemporal preference: today vs. one month & & & & 1,621 & 3.170 & $\begin{array}{c}-0.167^{* * *} \\
(0.045) \\
{[0.000]}\end{array}$ & 1,553 & 2.971 & $\begin{array}{c}-0.085^{*} \\
(0.049) \\
{[0.174]}\end{array}$ \\
\hline
\end{tabular}

Notes: *** significant at $1 \%, * *$ significant at $5 \%, *$ significant at $10 \%$, based on $p$-values unadjusted for multiple-hypothesis testing. Clustered standard errors at the municipality level (in parenthesis). Romano-Wolf adjusted $p$-values (in square brackets). Regressions control for randomization blocks, individual and household characteristics (gender, age, number of member in the household,...) and bank characteristics. The control means column shows non-standardized values. The lower number of observations is due to missing observations (respondents reporting they don't know or refuse to answer). 
Historically, many MFA beneficiaries believed they were not allowed to leave any money in MFA bank accounts because it would be "sent back" to the government. This caused a practice of withdrawing all funds from their accounts following the transfer. While this was true early on in the MFA program, the practice or returning funds was eliminated several years earlier. In one of the LISTA modules, the beneficiaries are taught that balances left in the MFA bank accounts are safe following their MFA transfer. Results indicate that the probability of believing they can leave money in their MFA account increased significantly for the treatment compared to the control group in the short-term, while decreasing in magnitude, with significance in the medium- and no significance in the long-term following the multiple-hypothesis correction.

Intertemporal Preferences. Respondents were asked whether they preferred 80 thousand COP in cash compared to 80, 90 or 100 thousand COP in a bank (and vice versa). Based on these responses, we constructed a bank over cash preference scale that goes from 1 (always cash taker) to 6 (always bank taker). Similarly, individuals were asked to choose between 80 thousand COP today or receiving successively higher amounts in one month in order to construct an intertemporal preference scale, which ranks from lower to higher patience.

A significant impact is found for intertemporal preferences and preferences for money in a bank over cash (Table 4). Significant medium-term and long-term intertemporal preferences were -0.17 sd and -0.09 sd, indicating greater patience. This suggests that beneficiaries may have accumulated more savings or felt more confident about their ability to manage cash flows and expenses. Meanwhile, preferences for money in bank over cash strengthened over the short-, medium-, and long-term, with $0.16,0.18$, and 0.19 sd changes, respectively. These preference shifts may be linked to, and become vital for, changing financial habits and preferences in the future. Overall, treated beneficiaries were less likely to prefer money today or to need it on hand immediately, implying that they were more patient or had fewer liquidity constraints. This result likewise suggests that acquisition of basic financial knowledge and positive changes in attitudes towards banks may lead to changes in behavior.

In sum, LISTA had an impact on basic financial knowledge, attitudes, and preferences. Next, we examine whether these shifts translated into practice adoption.

\subsection{Financial Practices}

As found in previous financial education evaluations, knowledge and attitudes may change, but this need not imply the adoption of new financial practices. We analyzed whether the program had an effect on concrete financial practices adoption such as CCT withdrawals, ATM use, savings habits, budgeting, and technology use ${ }^{17}$ Tables 5 to 7 report these results.

\footnotetext{
${ }^{17}$ A section of questions related to technology use was introduced at the second follow-up survey. As expected, use of tablets over the previous six months was significantly higher in the treatment group. But interestingly, the probability of use of other forms of technology in particular, use of Facebook, WhatsApp, video applications on the cellphone also increased after intervention, indicating that the intervention may have helped to reduce barriers to technology use. See the Supplemental Material document for results.
} 
MFA practices. As discussed above, LISTA sought to eliminate myths about the MFA program and encourage new withdrawal practices ensuring the female beneficiary's control over the transfer. A major issue is how the beneficiary withdraws the transfer and whether she leaves funds in the account for safekeeping or withdraws it all, either submitting to the temptation to spend it or increasing the likelihood of others accessing the funds. In the medium-term, the program had a positive effect on the probability of leaving money in the MFA account, while a long-term effect was found on whether the beneficiary was the person who withdrew the cash transfer. This indicates that treated beneficiaries not only changed beliefs about whether money could be left in their accounts (as seen in the "Financial Attitudes" section), but they put that belief into practice and started leaving money in their MFA accounts, a finding confirmed below with the bank administrative data. Nevertheless, the difference in leaving money in the MFA account appears to have disappeared in the long-term, based on self-report.

More people in the treatment also withdrew money while accompanied with another person, but in the medium- and long-term this effect disappeared. This short-term finding was unexpected. The assumption was that the tablet content would foster more individual and independent withdrawals. The program encouraged users to not share their cards nor their pin passwords because they were unable to use or felt uncomfortable engaging with an ATM. In the medium-term, questions were added to understand the shift. A hypothesis for why more women in the treatment group went with others to the ATM is discussed below.

ATM use. A range of questions explored ATM practices. No impact was detected for inducing members of the treatment group to use ATMs as their withdrawal channel, nor were there differences for sharing their card with others. This may be due to external constraints related to ATM access. Short-term outcomes indicate that the ATM simulator may have increased the probability of feeling capable of teaching someone to use the ATM, given the unexpected increase in the number of people in the treatment group who accompanied someone to withdraw their transfers from the ATM. To examine whether the ATM gamification-based learning module was put into practice, we further asked at the second and third follow-ups if those who felt capable of teaching others had actually taught someone in the previous six months. We found a significant increase in the medium-term, with the treatment reporting teaching their friends, neighbors, or strangers to use the ATM. Yet no effect was found in the long-term. Beyond CCT, ATM, and technology practices, we also examined budgeting and savings habits.

Budgeting habits. In the short- and medium-term, a marginally significant impact was found in whether the beneficiaries (91 percent female) were those responsible for managing household finances. Yet no effect was found relating to the probability of a treated beneficiary keeping written track of the household accounts. 
Table 5: Impact of LISTA on Financial Practices (ATM, MFA)

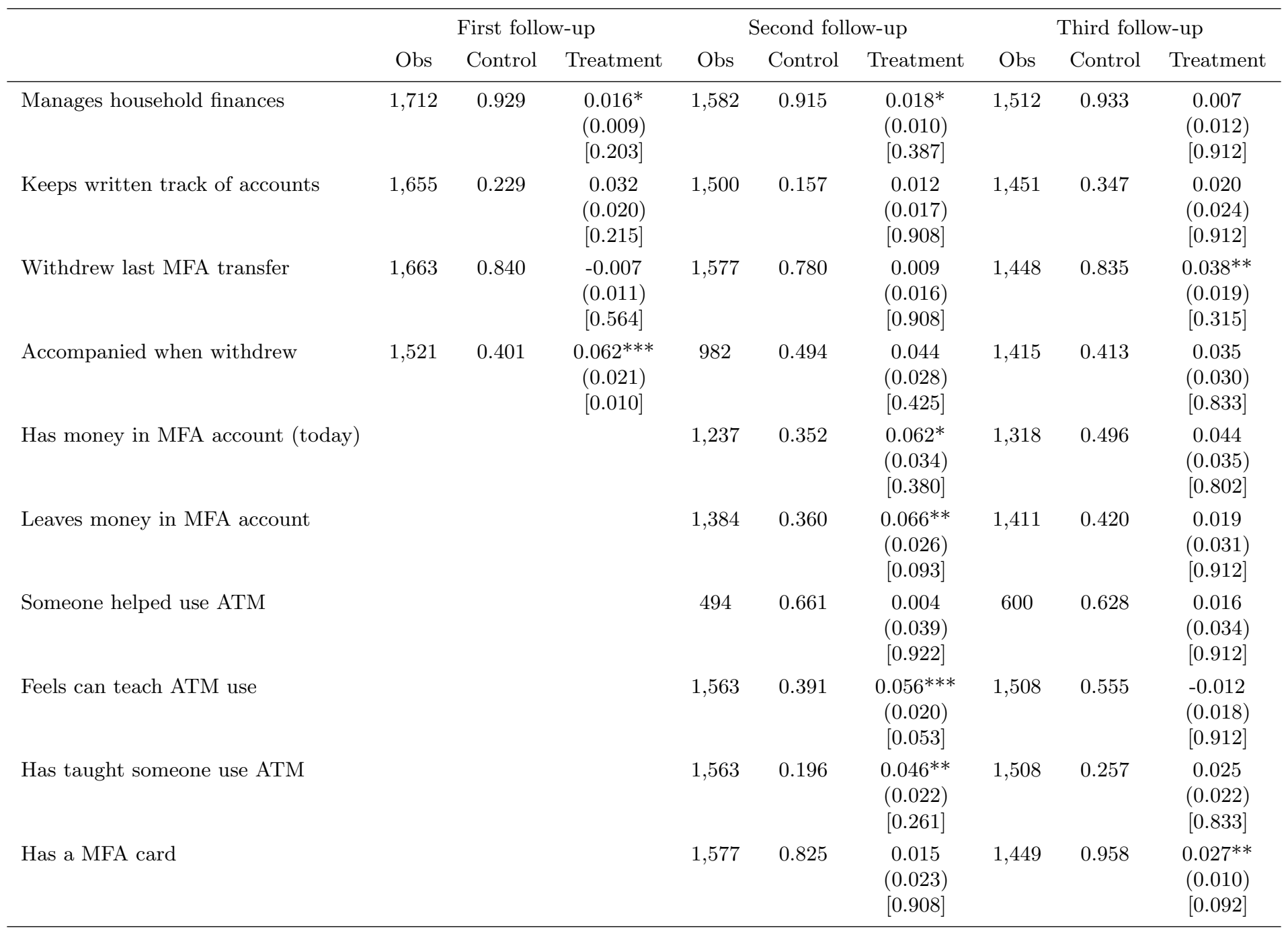

Notes: $* * *$ significant at $1 \%, * *$ significant at $5 \%, *$ significant at $10 \%$, based on $p$-values unadjusted for multiple-hypothesis testing. Clustered standard errors at the municipality level (in parenthesis). Romano-Wolf adjusted $p$-values (in square brackets). Regressions control for randomization blocks, individual and household characteristics (gender, age, number of member in the household,...) and bank characteristics. The control means column shows non-standardized values. 
Budgeting and saving. The survey included two multiple response questions regarding budgeting and savings practices in the face of hypothetical situations. Respondents were asked what they would do in the case of an emergency when they needed a certain amount of money. Over 17 percent of the treatment chose "using savings" in the short-term, nearly doubling that of control, while in the medium-term more than double selected "using saving" (Table 6). Interestingly, a statistically significant substitution appeared between those who opted to pawn something versus those who would look for a job, with the treatment preferring the former over the latter. Despite the multiple choices given, the results suggest a substitution with the "using loan" option. Similar results with slightly smaller magnitudes were found for the long-term.

When asked what they would do with a similar windfall, no impact in distribution was found, suggesting that although the treatment group may be saving more, enabling them to buffer against external shocks (a finding also found with the stated of savings goals), this does not necessarily mean that treatment members generated such a large surplus that they perceived greater utility (compared to control) in saving the hypothetical windfall. The three most popular options for both treatment and control were invest in a business, followed by savings and home investment. These hypothetical questions call for deeper understanding of savings goals and habits.

Finally, there is evidence of better expense management. In the medium-term, a marginal effect that failed to survive the multiple-hypothesis correction was detected on the self-reported ability to cover expenses over the past six months. Yet these results strengthened in the long-term, with 7.5 percentage points more in the treatment claiming they could cover their expenses, amounting to a statistically significant 21 percent increase, robust to the multiple-hypothesis correction. This evidence is further supported by the fact that no significant differences were found for weekly household expenditures. In other words, our data suggest that the intervention did not increase household expenditures (a proxy for increased cash flow) but did promote better saving habits (as seen in the next sections) and, thus, improved budget management.

Saving habits. The LISTA intervention emphasized the importance of setting a savings goal, and results suggest that the treatment had a positive and significant impact (Table 4). In the short-term, the probability of having a saving goal was around 17 percentage points higher compared to the control group mean, representing a 45 percent increase. This significant effect remained in the medium- and long-term, with 9 and 15 percentage point differences, which translate into 33 and 53 percent increases, respectively. The data also suggest that the intervention improved the probability of setting a saving goal for emergencies among the LISTA recipients, while LISTA beneficiaries were less likely to specify household and business improvement savings objectives.

To further test the impact of LISTA on savings habits, the survey asked whether beneficiaries saved money and where they saved it (see Panel A of Table 7). More people in the treatment group reported saving (both formally and informally), yet this impact was only significant in the shortterm. The same result appeared when analyzing if people saved at all formally, with short-term impact yet with no medium- or long-term effect. There is a marginally significant improvement in 
formal savings in the long-term, driven by more savings in cooperatives compared to the control group. This is evident when disaggregating the formal savings; even though saving in groups and cooperatives was significant in the medium-term, the largest component of these savings channels (in a bank) was significant only in the short-term.

Impact on informal savings habits were present across all three follow-ups. In the short-term, LISTA boosted the percentage of people saving informally by 15 percentage points, a growth of 26 percent over control. The impact persisted in the medium-term and long-term, with 11 and 10 percentage points more saving informally compared to control, a 32 percent and 26 percent increase, respectively. In other words, treated users reported that they were more likely to save, particularly at home (informal savings). There is some indication that users could be substituting the initial attempt to save formally in the short-term with informal savings in the medium- and long-term, given the disappearance of formal savings habits between the short- and medium-term combined with maintenance of the percentage growth of informal savers in the medium- and long-term. The treatment group is thus not losing the savings habit spurred by the intervention, as seen in the maintenance of a savings goal and savings habits across all three follow-ups. Rather, users seem to opt for informal savings in the medium- and long-term, suggesting the possible existence of formal savings barriers.

Taken together, the loss of comfort in the banks, external constraints related to ATM access, and the shift from formal to informal savings habits, all raise questions about supply-side barriers to formal savings given the persistence of informal savings habits. Despite evidence of increases in knowledge and expressed trust in the financial entity, if the product is too costly or poorly designed, adoption will suffer. Evidence on financial performance further supports this assertion.

\subsection{Financial Performance}

Self-reported savings. For the self-reported savings data, the impact of the intervention on the aggregate amount of money saved formally and informally is significant for the short-, medium-, and long-term in the Tobit estimation (see Panel B of Table 7). But this was not the case for the total amount of self-reported formal savings, in which only a short-term impact was detected. This finding aligns with the shift in self-reported formal savings habits between the short- and mediumterm. Interestingly, Tobit estimates of self-reported bank savings and OLS estimates using the bank administrative data are both around 17,000 Colombian pesos. In other words, at both the extensive and intensive margins, LISTA appears to have had less of an impact on saving in formal financial institutions over time, compared to informal savings. Unfortunately, we lack access to the medium- and long-term bank data to further confirm this hypothesis.

Bank savings and transactionality. Bank administrative data corroborate the self-reported short-term impact on formal savings (see Table 9). The treatment group had higher average savings in the partner banks in the months following the start of the intervention up until three months after it ended, or until December 2015, the last date the bank data were available. 
Table 6: Impact of LISTA on Financial Practices (Budgeting)

\begin{tabular}{|c|c|c|c|c|c|c|c|c|c|}
\hline & \multicolumn{3}{|c|}{ First follow-up } & \multicolumn{3}{|c|}{ Second follow-up } & \multicolumn{3}{|c|}{ Third follow-up } \\
\hline & Obs & Control & Treatment & Obs & Control & Treatment & Obs & Control & Treatment \\
\hline \multicolumn{10}{|l|}{ In case of a $350 \mathrm{k}$ emergency } \\
\hline Would use savings & 2,412 & 0.193 & $\begin{array}{c}0.171^{* * *} \\
(0.023) \\
{[0.000]}\end{array}$ & 2,223 & 0.069 & $\begin{array}{c}0.084^{* * *} \\
(0.010) \\
{[0.000]}\end{array}$ & 2,121 & 0.085 & $\begin{array}{c}0.061^{* * *} \\
(0.016) \\
{[0.000]}\end{array}$ \\
\hline Would use loans & 2,412 & 0.752 & $\begin{array}{c}-0.161^{* * *} \\
(0.023) \\
{[0.000]}\end{array}$ & 2,223 & 0.822 & $\begin{array}{c}-0.109 * * * \\
(0.017) \\
{[0.000]}\end{array}$ & 2,121 & 0.838 & $\begin{array}{c}-0.066^{* * *} \\
(0.020) \\
{[0.004]}\end{array}$ \\
\hline Would sell or pawn something & 2,412 & 0.036 & $\begin{array}{c}-0.006 \\
(0.007) \\
{[0.407]}\end{array}$ & 2,223 & 0.099 & $\begin{array}{c}0.023 \\
(0.014) \\
{[0.111]}\end{array}$ & 2,121 & 0.042 & $\begin{array}{c}0.007 \\
(0.010) \\
{[0.761]}\end{array}$ \\
\hline Would look for a job & & & & 2,247 & 0.029 & $\begin{array}{c}-0.014^{* *} \\
(0.006) \\
{[0.046]}\end{array}$ & 2,141 & 0.026 & $\begin{array}{c}-0.000 \\
(0.007) \\
{[0.879]}\end{array}$ \\
\hline \multicolumn{10}{|l|}{ In case of receiving $300 \mathrm{k}$ extra } \\
\hline Would save & & & & 2,305 & 0.852 & $\begin{array}{l}0.046^{* *} \\
(0.018) \\
{[0.051]}\end{array}$ & 2,177 & 0.833 & $\begin{array}{c}0.042^{* *} \\
(0.017) \\
{[0.065]}\end{array}$ \\
\hline Would spend on healthcare or education & & & & 2,305 & 0.083 & $\begin{array}{c}0.008 \\
(0.012) \\
{[0.659]}\end{array}$ & 2,172 & 0.962 & $\begin{array}{c}0.004 \\
(0.009) \\
{[0.737]}\end{array}$ \\
\hline Would build, improve or buy a house & & & & 2,294 & 0.796 & $\begin{array}{c}-0.019 \\
(0.019) \\
{[0.659]}\end{array}$ & 2,172 & 0.802 & $\begin{array}{c}0.016 \\
(0.019) \\
{[0.737]}\end{array}$ \\
\hline Would spend on household expenses & & & & 2,305 & 0.063 & $\begin{array}{c}-0.019 * \\
(0.010) \\
{[0.224]}\end{array}$ & 2,175 & 0.833 & $\begin{array}{c}-0.012 \\
(0.017) \\
{[0.737]}\end{array}$ \\
\hline Would invest in business & & & & 2,300 & 0.843 & $\begin{array}{c}0.013 \\
(0.015) \\
{[0.659]}\end{array}$ & 2,176 & 0.895 & $\begin{array}{c}0.022 \\
(0.014) \\
{[0.389]}\end{array}$ \\
\hline Was able to cover household expenses ${ }^{1 /}$ & & & & 2,112 & 0.361 & $\begin{array}{c}0.036^{*} \\
(0.021) \\
{[0.146]}\end{array}$ & 2,004 & 0.366 & $\begin{array}{c}0.075^{* * *} \\
(0.022) \\
{[0.002]}\end{array}$ \\
\hline Household weekly expenditure ${ }^{1 /}$ & & & & 2,112 & $143,146.708$ & $\begin{array}{c}0.004 \\
(0.046) \\
{[0.923]}\end{array}$ & 1,968 & $154,229.275$ & $\begin{array}{c}-0.008 \\
(0.057) \\
{[0.885]}\end{array}$ \\
\hline
\end{tabular}

Notes: $* * *$ significant at $1 \%, * *$ significant at $5 \%, *$ significant at $10 \%$, based on $p$-values unadjusted for multiple-hypothesis testing. Clustered standard errors at the municipality level (in parenthesis). Romano-Wolf adjusted $p$-values (in square brackets). Regressions control for randomization blocks, individual and household characteristics (gender, age, number of member in the household,...) and bank characteristics. The control means column shows non-standardized values. $1 /$ Regressions additionally control for weekly expenditure measured and amount of loan received measured at the baseline. Household weekly expenditure was standardized and the control group mean columns show non-standardized values in pesos. 
Table 7: Impact of LISTA on Financial Performance (Savings) - Self-reported

\begin{tabular}{|c|c|c|c|c|c|c|c|c|c|}
\hline & \multicolumn{3}{|c|}{ First follow-up } & \multicolumn{3}{|c|}{ Second follow-up } & \multicolumn{3}{|c|}{ Third follow-up } \\
\hline & Obs & Control & Treatment & Obs & Control & Treatment & Obs & Control & Treatment \\
\hline \multicolumn{10}{|l|}{ Panel A: Probability of saving } \\
\hline Has formal or informal savings & 2,502 & 0.601 & $\begin{array}{c}0.146^{* * *} \\
(0.023)\end{array}$ & 2,305 & 0.385 & $\begin{array}{c}0.110^{* * *} \\
(0.018)\end{array}$ & 2,180 & 0.434 & $\begin{array}{c}0.115^{* * *} \\
(0.022)\end{array}$ \\
\hline Has formal savings & 2,502 & 0.105 & $\begin{array}{l}0.030^{* *} \\
(0.013)\end{array}$ & 2,305 & 0.092 & $\begin{array}{c}0.008 \\
(0.011)\end{array}$ & 2,178 & 0.101 & $\begin{array}{c}0.026^{*} \\
(0.014)\end{array}$ \\
\hline Has informal savings & 2,501 & 0.568 & $\begin{array}{c}0.148^{* * *} \\
(0.022)\end{array}$ & 2,304 & 0.334 & $\begin{array}{c}0.108^{* * *} \\
(0.019)\end{array}$ & 2,180 & 0.390 & $\begin{array}{c}0.103^{* * *} \\
(0.021)\end{array}$ \\
\hline Has savings in a bank & 2,488 & 0.052 & $\begin{array}{c}0.029^{* * *} * \\
(0.009) \\
{[0.000]}\end{array}$ & 2,299 & 0.063 & $\begin{array}{c}-0.003 \\
(0.009) \\
{[0.705]}\end{array}$ & 2,170 & 0.063 & $\begin{array}{c}0.010 \\
(0.012) \\
{[0.369]}\end{array}$ \\
\hline Has savings in cooperative & 2,481 & 0.059 & $\begin{array}{c}0.017 \\
(0.011) \\
{[0.151]}\end{array}$ & 2,297 & 0.032 & $\begin{array}{c}0.015^{*} \\
(0.008) \\
{[0.107]}\end{array}$ & 2,172 & 0.045 & $\begin{array}{c}0.022^{* * *} \\
(0.008) \\
{[0.003]}\end{array}$ \\
\hline Has savings in piggy bank & 2,492 & 0.559 & $\begin{array}{c}0.148^{* * *} \\
(0.022) \\
{[0.000]}\end{array}$ & 2,298 & 0.325 & $\begin{array}{c}0.104^{* * *} \\
(0.018) \\
{[0.000]}\end{array}$ & 2,173 & 0.360 & $\begin{array}{c}0.094 * * * \\
(0.017) \\
{[0.000]}\end{array}$ \\
\hline \multicolumn{10}{|l|}{ Panel B: Tobit estimates for savings } \\
\hline Total formal and informal savings & 2,502 & 115,635 & $\begin{array}{c}0.516^{* * *} \\
(0.158)\end{array}$ & 2,305 & 138,010 & $\begin{array}{l}0.858^{* *} \\
(0.339)\end{array}$ & 2,180 & 156,347 & $\begin{array}{c}0.907^{* * *} \\
(0.283)\end{array}$ \\
\hline Total formal savings & 2,502 & 38,248 & $\begin{array}{c}1.244^{*} \\
(0.659)\end{array}$ & 2,305 & 63,128 & $\begin{array}{c}0.990 \\
(1.205)\end{array}$ & 2,179 & 57,070 & $\begin{array}{c}1.534 \\
(1.003)\end{array}$ \\
\hline Total informal savings & 2,502 & $70,933.812$ & $\begin{array}{c}0.505^{* * *} \\
(0.161)\end{array}$ & 2,305 & 53,033 & $\begin{array}{c}0.809^{* * *} \\
(0.268)\end{array}$ & 2,120 & 88,950 & $\begin{array}{c}1.040^{* * *} \\
(0.250)\end{array}$ \\
\hline Savings in a bank & 2,502 & 17,161 & $\begin{array}{c}3.214^{* * *} \\
(1.070) \\
{[0.009]}\end{array}$ & 2,305 & 39,249 & $\begin{array}{c}0.252 \\
(2.019) \\
{[0.886]}\end{array}$ & 2,172 & 26,124 & $\begin{array}{c}1.033 \\
(1.272) \\
{[0.435]}\end{array}$ \\
\hline Savings in cooperative & 2,502 & 15,722 & $\begin{array}{c}0.860 \\
(2.338) \\
{[0.695]}\end{array}$ & 2,305 & 11,429 & $\begin{array}{c}4.288 \\
(3.598) \\
{[0.409]}\end{array}$ & 2,180 & 19,446 & $\begin{array}{l}7.509^{* *} \\
(3.097) \\
{[0.034]}\end{array}$ \\
\hline Savings in piggy bank & 2,502 & 62,864 & $\begin{array}{c}0.464^{* * *} \\
(0.169) \\
{[0.019]}\end{array}$ & 2,305 & 42,182 & $\begin{array}{c}0.843^{* * *} \\
(0.274) \\
{[0.004]}\end{array}$ & 2,120 & 63,510 & $\begin{array}{c}0.788^{* * *} \\
(0.158) \\
{[0.000]}\end{array}$ \\
\hline
\end{tabular}

Notes: *** significant at $1 \%, * *$ significant at $5 \%, *$ significant at $10 \%$, based on $p$-values unadjusted for multiple-hypothesis testing. Clustered standard errors at the municipality level (in parenthesis). Romano-Wolf adjusted $p$-values (in square brackets). Regressions control for randomization blocks, individual and household characteristics (gender, age, number of member in the household,...) and bank characteristics. The control means column shows non-standardized values. 
Table 8: Impact of LISTA on Financial Performance (Savings/Expediture) - Self-reported

\begin{tabular}{|c|c|c|c|c|c|c|c|c|c|}
\hline & \multicolumn{3}{|c|}{ First follow-up } & \multicolumn{3}{|c|}{ Second follow-up } & \multicolumn{3}{|c|}{ Third follow-up } \\
\hline & Obs & Control & Treatment & Obs & Control & Treatment & Obs & Control & Treatment \\
\hline Total savings/expenditure & & & & 2,096 & 1.278 & $\begin{array}{c}0.028 \\
(0.043)\end{array}$ & 1,963 & 1.344 & $\begin{array}{c}0.267^{* *} \\
(0.108)\end{array}$ \\
\hline Formal savings/expenditure & & & & 2,096 & 0.509 & $\begin{array}{c}0.058 \\
(0.047)\end{array}$ & 1,962 & 0.479 & $\begin{array}{c}0.391 \\
(0.314)\end{array}$ \\
\hline Savings in piggy bank/expenditure & & & & 2,096 & 0.441 & $\begin{array}{c}-0.004 \\
(0.037) \\
{[0.994]}\end{array}$ & 1,910 & 0.539 & $\begin{array}{c}0.486^{* * *} \\
(0.109) \\
{[0.001]}\end{array}$ \\
\hline
\end{tabular}

Notes: *** significant at $1 \%, * *$ significant at $5 \%, *$ significant at $10 \%$, based on $p$-values unadjusted for multiple-hypothesis testing. Clustered standard errors at the municipality level (in parenthesis). Romano-Wolf adjusted $p$-values (in square brackets). Regressions control for randomization blocks, individual and household characteristics (gender, age, number of member in the household,...) and bank characteristics. The control means column shows non-standardized values. 
Analysis of the administrative data did not indicate overall increased transactionality with the bank, e.g., more use of debit, credit, withdrawals, or deposits. In fact, the coefficient for a composite measure of transactionality was negative for the treatment, suggesting that users overall interacted less with their bank account. The analysis of heterogeneous effects suggest that this is the result of statistically significant less transactionality in the Caribbean. It should also be noted that for MFA accounts, fees were charged for transactions after surpassing a minimal threshold of use.

Credit. At end of 2017, when the third follow-up was administered, the credit system data indicated a marginally significant 19 percent decrease in the proportion of the treatment group that had taken out a formal loan since the start of the intervention (Table 10). Much of this impact appears to have occurred between 2015 and 2016, when there was a significant 25 percent decrease in whether the treatment had taken a formal loan.

More robust findings emerge when the sample is examined only for the 91 percent of women in the sample. For them, the impact strengthened over time, with women systematically taking out less credit, with a marginally significant decrease of 23 percent in 2015 and 2016 and a significant decrease of 26 percent between 2015 and 2017. It appears that this is driven mostly by a statistically significant reduction in credit card use. Finally, it should be noted that all people in the sample received the CCT benefit. Previous evidence on this population has identified a positive effect in the extensive margin of credit (a 15 percent increase) for MFA program beneficiaries (Cardona et al., 2017). It is reasonable to hypothesize that the LISTA intervention decreased formal credit use on top of the positive impact created by participation in the CCT program.

Spending. Self-reported weekly savings data were collected at the baseline and third followup, with detailed six-month, monthly, and weekly spending data collected for the second follow-up. No spending differences were detected, although significant savings impacts were found. A possible explanation is that the intervention may have impacted income; unfortunately, we could not collect data for this variable.

Regardless, evidence indicates that even with an effective demand-side intervention targeting financial literacy and capability, it is important to take into account supply-side constraints associated with access, products, and services. Financial inclusion is not equivalent to financial health. Taken together, these findings - more informal savings, less use of formal credit, specified savings goals focused on emergencies, and reported ease of meeting household expenses though without a rise in household expenditures - all paint an emerging picture of increased financial health for the treatment households (CSFI, 2017).

\subsection{Psychosocial Indicators}

Given impact found at the first follow-up, the second and third follow-ups attempted light measures of participant attitudes towards themselves, their life, and others. Results indicate that LISTA had varying impact on these outcomes given the measures used (Table 11). 
Table 9: Impact of LISTA on Financial Performance - Administrative Data

\begin{tabular}{|c|c|c|c|c|c|c|c|}
\hline & May-Jun & Jun-Jul & Jul-Aug & Aug-Sep & Sep-Oct & Oct-Nov & Nov-Dec \\
\hline \multicolumn{8}{|l|}{ Panel A: Non-standardized effects } \\
\hline Number of monthly withdraws (a) & $\begin{array}{l}-0.005 \\
(0.004)\end{array}$ & $\begin{array}{l}-0.012 \\
(0.015)\end{array}$ & $\begin{array}{l}-0.026 \\
(0.023)\end{array}$ & $\begin{array}{c}0.003 \\
(0.014)\end{array}$ & $\begin{array}{c}0.016 \\
(0.019)\end{array}$ & $\begin{array}{l}-0.005 \\
(0.014)\end{array}$ & $\begin{array}{l}-0.018 \\
(0.031)\end{array}$ \\
\hline Number of other debit transactions (b) & $\begin{array}{l}-0.003 \\
(0.004)\end{array}$ & $\begin{array}{r}-0.022^{*} \\
(0.012)\end{array}$ & $\begin{array}{c}-0.025^{* *} \\
(0.012)\end{array}$ & $\begin{array}{l}-0.007 \\
(0.014)\end{array}$ & $\begin{array}{c}0.001 \\
(0.013)\end{array}$ & $\begin{array}{c}0.004 \\
(0.008)\end{array}$ & $\begin{array}{c}0.006 \\
(0.010)\end{array}$ \\
\hline Number of total debit transactions $(a)+(b)$ & $\begin{array}{l}-0.005 \\
(0.005)\end{array}$ & $\begin{array}{l}-0.033 \\
(0.022)\end{array}$ & $\begin{array}{c}-0.051^{*} \\
(0.028)\end{array}$ & $\begin{array}{l}-0.006 \\
(0.019)\end{array}$ & $\begin{array}{l}0.018 \\
(0.022)\end{array}$ & $\begin{array}{c}-0.004 \\
(0.015)\end{array}$ & $\begin{array}{l}-0.023 \\
(0.031)\end{array}$ \\
\hline Number of active credits (c) & $\begin{array}{c}0.001 \\
(0.001)\end{array}$ & $\begin{array}{l}0.000 \\
(0.001)\end{array}$ & $\begin{array}{l}0.000 \\
(0.001)\end{array}$ & $\begin{array}{c}0.003 \\
(0.002)\end{array}$ & $\begin{array}{c}0.003 \\
(0.002)\end{array}$ & $\begin{array}{c}0.001 \\
(0.001)\end{array}$ & $\begin{array}{c}0.000 \\
(0.001)\end{array}$ \\
\hline Number of monthly deposits (d) & $\begin{array}{l}-0.007^{*} \\
(0.004)\end{array}$ & $\begin{array}{l}0.006 \\
(0.007)\end{array}$ & $\begin{array}{c}0.011 \\
(0.015)\end{array}$ & $\begin{array}{c}0.012 \\
(0.007)\end{array}$ & $\begin{array}{l}-0.000 \\
(0.008)\end{array}$ & $\begin{array}{l}0.015^{*} \\
(0.008)\end{array}$ & $\begin{array}{c}0.028 \\
(0.018)\end{array}$ \\
\hline Total transactionality $(\mathrm{a})+(\mathrm{b})+(\mathrm{c})+(\mathrm{d})$ & $\begin{array}{l}-0.016 \\
(0.011)\end{array}$ & $\begin{array}{l}-0.025 \\
(0.023)\end{array}$ & $\begin{array}{l}-0.036 \\
(0.031)\end{array}$ & $\begin{array}{c}0.009 \\
(0.023)\end{array}$ & $\begin{array}{c}0.020 \\
(0.024)\end{array}$ & $\begin{array}{c}0.011 \\
(0.019)\end{array}$ & $\begin{array}{l}-0.001 \\
(0.042)\end{array}$ \\
\hline Average monthly account balance & $\begin{array}{c}282.884 \\
(408.465)\end{array}$ & $\begin{array}{c}2,782.711^{* * *} \\
(783.502)\end{array}$ & $\begin{array}{c}4,330.339^{* * *} \\
(879.883)\end{array}$ & $\begin{array}{c}3,587.273^{* * *} \\
(1,295.289)\end{array}$ & $\begin{array}{c}3,178.461^{* *} \\
(1,361.245)\end{array}$ & $\begin{array}{l}2,757.618^{*} \\
(1,421.726)\end{array}$ & $\begin{array}{c}3,650.628^{* *} \\
(1,624.026)\end{array}$ \\
\hline \multicolumn{8}{|l|}{ Panel B: Standardized effects } \\
\hline Number of monthly withdraws (a) & $\begin{array}{l}-0.008 \\
(0.007)\end{array}$ & $\begin{array}{l}-0.020 \\
(0.025)\end{array}$ & $\begin{array}{l}-0.045 \\
(0.039)\end{array}$ & $\begin{array}{c}0.005 \\
(0.024)\end{array}$ & $\begin{array}{c}0.028 \\
(0.032)\end{array}$ & $\begin{array}{l}-0.009 \\
(0.025)\end{array}$ & $\begin{array}{l}-0.030 \\
(0.052)\end{array}$ \\
\hline Number of other debit transactions (b) & $\begin{array}{l}-0.012 \\
(0.018)\end{array}$ & $\begin{array}{l}-0.092^{*} \\
(0.050)\end{array}$ & $\begin{array}{c}-0.105^{* *} \\
(0.050)\end{array}$ & $\begin{array}{l}-0.029 \\
(0.060)\end{array}$ & $\begin{array}{c}0.004 \\
(0.054)\end{array}$ & $\begin{array}{c}0.017 \\
(0.033)\end{array}$ & $\begin{array}{c}0.024 \\
(0.044)\end{array}$ \\
\hline Number of total debit transactions $(\mathrm{a})+(\mathrm{b})$ & $\begin{array}{l}-0.008 \\
(0.008)\end{array}$ & $\begin{array}{l}-0.053 \\
(0.036)\end{array}$ & $\begin{array}{c}-0.084^{*} \\
(0.046)\end{array}$ & $\begin{array}{l}-0.009 \\
(0.030)\end{array}$ & $\begin{array}{c}0.029 \\
(0.036)\end{array}$ & $\begin{array}{l}-0.006 \\
(0.025)\end{array}$ & $\begin{array}{l}-0.037 \\
(0.050)\end{array}$ \\
\hline Number of active credits (c) & $\begin{array}{c}0.036 \\
(0.032)\end{array}$ & $\begin{array}{c}0.010 \\
(0.042)\end{array}$ & $\begin{array}{l}0.008 \\
(0.044)\end{array}$ & $\begin{array}{c}0.105 \\
(0.066)\end{array}$ & $\begin{array}{l}0.078 \\
(0.055)\end{array}$ & $\begin{array}{l}0.016 \\
(0.042)\end{array}$ & $\begin{array}{c}0.006 \\
(0.043)\end{array}$ \\
\hline Number of monthly deposits (d) & $\begin{array}{l}-0.020^{*} \\
(0.012)\end{array}$ & $\begin{array}{c}0.017 \\
(0.019)\end{array}$ & $\begin{array}{c}0.028 \\
(0.039)\end{array}$ & $\begin{array}{c}0.031 \\
(0.019)\end{array}$ & $\begin{array}{l}-0.001 \\
(0.021)\end{array}$ & $\begin{array}{l}0.040^{*} \\
(0.022)\end{array}$ & $\begin{array}{c}0.072 \\
(0.047)\end{array}$ \\
\hline Total transactionality $(\mathrm{a})+(\mathrm{b})+(\mathrm{c})+(\mathrm{d})$ & $\begin{array}{l}-0.019 \\
(0.012)\end{array}$ & $\begin{array}{l}-0.028 \\
(0.026)\end{array}$ & $\begin{array}{l}-0.041 \\
(0.035)\end{array}$ & $\begin{array}{c}0.010 \\
(0.026)\end{array}$ & $\begin{array}{c}0.023 \\
(0.028)\end{array}$ & $\begin{array}{c}0.012 \\
(0.022)\end{array}$ & $\begin{array}{l}-0.001 \\
(0.048)\end{array}$ \\
\hline Average monthly account balance & $\begin{array}{c}0.005 \\
(0.007)\end{array}$ & $\begin{array}{c}0.048^{* * *} \\
(0.014)\end{array}$ & $\begin{array}{c}0.075^{* * *} \\
(0.015)\end{array}$ & $\begin{array}{c}0.062^{* * *} \\
(0.023)\end{array}$ & $\begin{array}{c}0.055^{* *} \\
(0.024)\end{array}$ & $\begin{array}{l}0.048^{*} \\
(0.025)\end{array}$ & $\begin{array}{c}0.064^{* *} \\
(0.028)\end{array}$ \\
\hline
\end{tabular}

Note: Average savings are standardized using the mean and the variance from January 2014. Controls include: randomization blocks, account is from Banco Agrario, two-month moving average savings up to April 2015, number of financial institutions in the district, and a set of socioeconomic covariates at the municipal level. Clustered standard errors in parenthesis. ${ }^{*} \mathrm{p}<.1,{ }^{* *} \mathrm{p}<.05,{ }^{* * *} \mathrm{p}<.01$. 
Table 10: Financial performance (Credit) - Administrative data

\begin{tabular}{|c|c|c|c|c|c|c|c|c|c|c|c|c|}
\hline & \multicolumn{6}{|c|}{ Full sample } & \multicolumn{6}{|c|}{ Female sub-sample } \\
\hline & \multicolumn{2}{|c|}{$2015-2016$} & \multicolumn{2}{|c|}{$2016-2017$} & \multicolumn{2}{|c|}{$2015-2017$} & \multicolumn{2}{|c|}{$2015-2016$} & \multicolumn{2}{|c|}{$2016-2017$} & \multicolumn{2}{|c|}{$2015-2017$} \\
\hline & Control & Treatment & Control & Treatment & Control & Treatment & Control & Treatment & Control & Treatment & Control & Treatment \\
\hline Credit & 0.059 & $\begin{array}{l}-0.008 \\
(0.007)\end{array}$ & 0.074 & $\begin{array}{c}-0.012 \\
(0.008)\end{array}$ & 0.080 & $\begin{array}{c}-0.014^{*} \\
(0.007)\end{array}$ & 0.057 & $\begin{array}{l}-0.010 \\
(0.007)\end{array}$ & 0.072 & $\begin{array}{c}-0.015^{*} \\
(0.008)\end{array}$ & 0.077 & $\begin{array}{c}-0.016^{* *} \\
(0.007)\end{array}$ \\
\hline Consumption credit & 0.018 & $\begin{array}{c}0.000 \\
(0.003) \\
{[0.970]}\end{array}$ & 0.021 & $\begin{array}{l}-0.001 \\
(0.004) \\
{[0.931]}\end{array}$ & 0.024 & $\begin{array}{l}-0.001 \\
(0.003) \\
{[0.208]}\end{array}$ & 0.019 & $\begin{array}{l}-0.001 \\
(0.003) \\
{[0.861]}\end{array}$ & 0.022 & $\begin{array}{l}-0.002 \\
(0.003) \\
{[0.931]}\end{array}$ & 0.024 & $\begin{array}{l}-0.002 \\
(0.003) \\
{[0.901]}\end{array}$ \\
\hline Credit with banks & 0.038 & $\begin{array}{c}0.003 \\
(0.005) \\
{[0.970]}\end{array}$ & 0.044 & $\begin{array}{c}0.003 \\
(0.006) \\
{[0.931]}\end{array}$ & 0.049 & $\begin{array}{c}0.001 \\
(0.006) \\
{[0.881]}\end{array}$ & 0.035 & $\begin{array}{c}0.001 \\
(0.005) \\
{[0.861]}\end{array}$ & 0.042 & $\begin{array}{l}-0.000 \\
(0.006) \\
{[0.931]}\end{array}$ & 0.046 & $\begin{array}{l}-0.002 \\
(0.006) \\
{[0.901]}\end{array}$ \\
\hline Credit card & 0.045 & $\begin{array}{c}-0.010 \\
(0.006) \\
{[0.4752]}\end{array}$ & 0.059 & $\begin{array}{c}-0.013^{*} \\
(0.007) \\
{[0.4752]}\end{array}$ & 0.064 & $\begin{array}{c}-0.016^{* *} \\
(0.007) \\
{[0.1584]}\end{array}$ & 0.042 & $\begin{array}{c}-0.010 \\
(0.006) \\
{[0.4356]}\end{array}$ & 0.056 & $\begin{array}{c}-0.015^{*} \\
(0.008) \\
{[0.3267]}\end{array}$ & 0.061 & $\begin{array}{c}-0.017^{* *} \\
(0.007) \\
{[0.1287]}\end{array}$ \\
\hline Default & 0.009 & $\begin{array}{c}0.002 \\
(0.003) \\
{[0.970]}\end{array}$ & 0.015 & $\begin{array}{l}-0.004 \\
(0.004) \\
{[0.871]}\end{array}$ & 0.019 & $\begin{array}{l}-0.003 \\
(0.004) \\
{[0.812]}\end{array}$ & 0.008 & $\begin{array}{c}0.003 \\
(0.003) \\
{[0.822]}\end{array}$ & 0.015 & $\begin{array}{l}-0.004 \\
(0.004) \\
{[0.782]}\end{array}$ & 0.019 & $\begin{array}{l}-0.003 \\
(0.004) \\
{[0.901]}\end{array}$ \\
\hline Max. default days & 1.695 & $\begin{array}{l}-0.138 \\
(0.194) \\
{[0.970]}\end{array}$ & 3.123 & $\begin{array}{l}-0.502 \\
(0.348) \\
{[0.604]}\end{array}$ & 2.458 & $\begin{array}{l}-0.298 \\
(0.237) \\
{[0.673]}\end{array}$ & 1.603 & $\begin{array}{c}0.022 \\
(0.118) \\
{[0.970]}\end{array}$ & 3.077 & $\begin{array}{l}-0.407 \\
(0.314) \\
{[0.703]}\end{array}$ & 2.459 & $\begin{array}{l}-0.240 \\
(0.210) \\
{[0.762]}\end{array}$ \\
\hline Total Average Debt & 154,963 & $\begin{array}{c}0.002 \\
(0.018)\end{array}$ & 188,400 & $\begin{array}{c}0.018 \\
(0.029)\end{array}$ & 171,114 & $\begin{array}{c}0.008 \\
(0.021)\end{array}$ & 145,972 & $\begin{array}{c}0.005 \\
(0.018)\end{array}$ & 180,161 & $\begin{array}{c}0.024 \\
(0.031)\end{array}$ & 162,864 & $\begin{array}{c}0.013 \\
(0.022)\end{array}$ \\
\hline Credit card debt & 37,592 & $\begin{array}{c}0.021 \\
(0.028) \\
{[0.970]}\end{array}$ & 45,432 & $\begin{array}{c}0.023 \\
(0.030) \\
{[0.871]}\end{array}$ & 41,391 & $\begin{array}{c}0.022 \\
(0.027) \\
{[0.812]}\end{array}$ & 35,105 & $\begin{array}{l}0.029 \\
(0.029) \\
{[0.861]}\end{array}$ & 42,957 & $\begin{array}{c}0.025 \\
(0.032) \\
{[0.871]}\end{array}$ & 38,949 & $\begin{array}{l}0.026 \\
(0.029) \\
{[0.901]}\end{array}$ \\
\hline Consumption credit debt & 171,444 & $\begin{array}{l}-0.005 \\
(0.017) \\
{[0.970]}\end{array}$ & 217,333 & $\begin{array}{l}0.007 \\
(0.027) \\
{[0.931]}\end{array}$ & 194,479 & $\begin{array}{l}-0.001 \\
(0.020) \\
{[0.881]}\end{array}$ & 167,584 & $\begin{array}{l}-0.003 \\
(0.016) \\
{[0.970]}\end{array}$ & 213,746 & $\begin{array}{l}0.015 \\
(0.028) \\
{[0.931]}\end{array}$ & 191,048 & $\begin{array}{l}0.004 \\
(0.020) \\
{[0.901]}\end{array}$ \\
\hline Av. number of credits per year & 0.165 & $\begin{array}{c}0.004 \\
(0.015) \\
{[0.970]}\end{array}$ & 0.296 & $\begin{array}{l}-0.023 \\
(0.027) \\
{[0.871]}\end{array}$ & 0.227 & $\begin{array}{l}-0.013 \\
(0.019) \\
{[0.643]}\end{array}$ & 0.161 & $\begin{array}{l}-0.005 \\
(0.015) \\
{[0.861]}\end{array}$ & 0.293 & $\begin{array}{l}-0.044 \\
(0.029) \\
{[0.545]}\end{array}$ & 0.224 & $\begin{array}{l}-0.027 \\
(0.020) \\
{[0.713]}\end{array}$ \\
\hline Observations & & 105 & & 105 & & 105 & & 820 & & 820 & & 820 \\
\hline
\end{tabular}

Notes :*** significant at $1 \%, * *$ significant at $5 \%$, * significant at $10 \%$. Clustered standard errors at the municipality level in parenthesis. Regressions control for randomization blocks, individual and average value of 2014. The control means column shows non-standardized values. The dependent variable of credit refer to persons either having a credit card or a consumption credit itself. Similarly, total debt includes consumption debt and credit card debt. 
Optimism and pessimism. Respondents were asked to use a Likert scale of one to seven to grade themselves on an optimism and pessimism continuum (Kemper et al., 2011). A statistically significant impact was detected in the medium-term - being part of the treatment group increased the level of optimism and decreased the level of pessimism among beneficiaries ${ }^{18}$ Yet this effect disappeared over the long-term.

Trust. Another set of questions, which borrowed one item and adapted another from the World Values Survey, asked beneficiaries if they trusted other people and how much they trusted them. Although there was no statistical difference between the control and treatment groups in trusting others in general, LISTA may have improved marginally the level of trust the treated beneficiaries felt towards others in their community over the medium-term. This could be a result of the rotation methodology implemented during the treatment. Specifically, social interaction between the MFA mother leader and her group members as a result of the tablet rotations may have generated enough social capital to increase levels of trust between people in the same community. Yet in the long-term, no differences were found.

While some results indicate a general shift in orientation over the medium-turn, they are more suggestive than definitive. The primary goal of the evaluation was to measure financial knowledge, practices, and performance impacts, and inadequate attention was paid to the effects of the female empowerment messaging.

\section{Potential Mechanisms}

Results indicate that a digital-based tool which incorporates simplified, actionable, concrete, targeted, and engaging content can be effective when combined with a community-based distribution methodology. But who did the intervention work best for and why? An examination of the heterogeneous effects helps specify mechanisms for further exploration.

\subsection{Heterogeneous Treatment Effects}

To identify initial insights into how the intervention generated impact, we explored heterogeneous effects by interacting the treatment with a series of socio-demographic variables: urban/rural, education (primary/secondary), poverty (quartiles), age (quartiles), and region (Caribbean/Pacific). In general, the more rural, less educated, poorer, and younger the individual, the greater the impact. This suggests that the intervention was effective in providing important information to households with relatively greater consumption smoothing and income shock challenges.

\footnotetext{
${ }^{18}$ Evidence suggests that optimism and pessimism may be two constructs. Less optimism, for example, does not imply necessarily that someone is more pessimistic and vice versa (Herzberg et al., 2006)
} 
Table 11: Impact of LISTA on Psychosocial Indicators

\begin{tabular}{|c|c|c|c|c|c|c|c|c|c|}
\hline & \multicolumn{3}{|c|}{ First follow-up } & \multicolumn{3}{|c|}{ Second follow-up } & \multicolumn{3}{|c|}{ Third follow-up } \\
\hline & Obs & Control & Treatment & Obs & Control & Treatment & Obs & Control & Treatment \\
\hline Optimism & & & & 2,241 & 5.785 & $\begin{array}{c}0.095 * * \\
(0.043) \\
{[0.151]}\end{array}$ & 2,128 & 5.846 & $\begin{array}{c}0.027 \\
(0.046) \\
{[0.723]}\end{array}$ \\
\hline Pessimism & & & & 2,252 & 2.404 & $\begin{array}{c}-0.119^{* * *} \\
(0.044) \\
{[0.047]}\end{array}$ & 2,114 & 2.859 & $\begin{array}{l}-0.055 \\
(0.060) \\
{[0.723]}\end{array}$ \\
\hline People trust & & & & 2,284 & 0.052 & $\begin{array}{c}-0.013 \\
(0.009) \\
{[0.359]}\end{array}$ & 2,172 & 0.114 & $\begin{array}{l}-0.024 \\
(0.015) \\
{[0.483]}\end{array}$ \\
\hline More trustworthy of other people & & & & 2,297 & 1.830 & $\begin{array}{l}0.080^{*} \\
(0.044) \\
{[0.278]}\end{array}$ & & & \\
\hline Interested in savings program & & & & 2,232 & 2.974 & $\begin{array}{c}0.055 \\
(0.055) \\
{[0.509]}\end{array}$ & & & \\
\hline $\begin{array}{l}\text { There are lots of ways around } \\
\text { any problem that I am facing now }\end{array}$ & & & & 2,305 & 5.743 & $\begin{array}{c}0.025 \\
(0.059) \\
{[0.667]}\end{array}$ & & & \\
\hline Is meeting her goals & & & & 2,305 & 5.312 & $\begin{array}{l}0.088^{*} \\
(0.052)\end{array}$ & & & \\
\hline Self-efficacy & & & & & & {$[0.292]$} & & & \\
\hline Future orientation & & & & & & & 2,180 & 3.017 & $\begin{array}{c}0.048 \\
(0.053) \\
{[0.723]}\end{array}$ \\
\hline Social capital & & & & & & & 2,180 & 3.255 & $\begin{array}{c}0.065 \\
(0.044) \\
{[0.483]}\end{array}$ \\
\hline & & & & & & & 2,180 & 1.709 & $\begin{array}{c}0.085 \\
(0.055) \\
{[0.483]}\end{array}$ \\
\hline
\end{tabular}

Notes: ${ }^{* * *}$ significant at $1 \%,{ }^{* *}$ significant at $5 \%, *$ significant at $10 \%$ (based on $p$-values unadjusted for multiple-hypothesis testing). $\dagger \dagger \dagger$ significant at $1 \%, \dagger \dagger$ significant at $5 \%, \dagger$ significant at $10 \%$ (based on $p$-values adjusted for multiple-hypothesis testing). Clustered standard errors at the municipality level in parenthesis. Regressions control for randomization blocks, individual and household characteristics (gender, age, number of member in the household,...) and bank characteristics. The control group means column show non-standardized values. 
Financial Knowledge and Attitudes. Overall, the broad and lasting effects of knowledge gains and savings goals suggest that the content was clear, easy to understand, and memorable. Yet there were differences. We consistently find at all follow-ups more gains among the rural and primary educated compared to the urban and secondary educated populations (Tables 21-26 in the Supplementary Material document). This was the case for savings and budget knowledge. The sample in the Pacific region, which is 75 percent rural, experienced larger gains in savings knowledge. In the long-term, savings knowledge improvements were greatest among the sample's middle income segments. Furthermore, those with greatest gains were the youngest quartile or those between the ages of 18 and 32 years.

With respect to attitudes (Tables 27-32 in the Supplementary Material), the relationship to the MFA account were similar across different groups. Yet, regarding attitudes towards banks and in contrast to the Caribbean, the Pacific region reported less trust and comfort with banks as well as a higher preference for cash in hand vs. having it in the bank. In the medium- and long-term, only people in the Caribbean reported more trust in the banks, while people in the Pacific region reported negative trust in the long-term. More trust and comfort was also registered among those in rural areas and with secondary education. Regarding intertemporal preferences, primary educated individuals reported preferring cash vs. banks while the youngest group exhibited more patience compared to the control.

Financial Practices. People across all segments reported similar gains in having a savings goals (Tables 33-38 in the Supplementary Material). As for budgeting practices, for the short- and medium-term people in rural areas reported more being able to manage their finances, an improvement also observed in the long-term for those living in the Caribbean. In the same region and in urban areas, people reported higher probabilities of leaving money in their accounts. The lack of this finding among those in the Pacific and rural areas aligns with the less trust in banks reported in the previous section, suggesting the possible existence of supply-side constraints.

More people in rural areas report feeling capable of teaching someone how to use an ATM, having also taught or accompanied someone to do so. This is also the case for those in the Pacific, a region with a large share of rural population. By level of education, while the primary educated report having been accompanied to an ATM, those with secondary education reported having taught someone how to use one, a skill also reported more by the youngest people in the study. This suggests the possible existence of a social mechanism with the secondary educated and younger people teaching the primary educated and older population how to use an ATM.

In the long-term, the only effects that remained were for people being able to manage their finances in the Caribbean region, and poorer people having an MFA card and having withdrawn their last MFA transfer themselves.

Financial Performance. As mentioned earlier, similar impacts on savings and budgeting knowledge and the setting of savings goals were found across groups (Tables 45-50 in the Supplementary 
Material). These results align with effects on whether people save informally, which were found across all groups and survey waves. On the one hand, it appears that in the long-term there was more impact on informal savings among the rural, less educated, and poorest population, which aligns with results for knowledge and practices. On the other hand, the rural, Caribbean, and better educated reported greater use of formal savings, while no impact was found for amount saved. In terms of age effects, larger savings magnitudes were seen among the older population groups. The primary educated reported greater impact in the ability to cover recent household expenses in the medium-term, with the effect strengthening in the long-term.

We were able to examine effects of region using the bank administrative data (Table 51 in the Supplementary Material). The results tell two stories and help to make sense of the differential impacts seen in the regions. In the Caribbean, users decreased their transactionality with the MFA bank and saved more by leaving more money in their account. Both categories of variables were significant across several months. In the Pacific region, however, transactionality increased significantly as did access to credit, while savings impacts were null. Given the nature of the MFA account, greater transactionality also implies more fees. This may have helped lead over time to less trust in banks in the Pacific region 19. In other words, initial steps toward financial inclusion may have occurred in the respective regions, with one taking a savings/low transactionality and the other a credit/high transactionality pathway.

Results once again indicate that in general the poorer, less educated, and the more rural the population, the stronger the impact on informal and overall savings. Furthermore, there are correlations in the sample between poverty, rural residence, educational level, age, and region.

\subsection{Discussion}

The patterns of heterogeneous effects lead us to hypothesize four mechanisms that may have reinforced one another to improve financial knowledge, attitudes, practices, and performance, with a fifth mechanism hindering formal financial inclusion: (i) simple, focused, and memorable content, (ii) social learning within the household, (iii) channel, (iv) social learning within the community, and (v) barriers to formal financial system access. Mechanisms ii, iii, and iv highlight the importance of leveraging a social component with digital interventions.

Content. The tablet content consisted of simple, focused, well-crafted messages communicated via testimonial videos and stories that sought to build an emotional identification and connection with the largely female audience. Certain components such as learning how to use the ATM and the importance of savings, were also communicated via gamification. Messages sought to be actionable in the areas of MFA practices, ATM withdrawals, savings, and budgeting. The impact detected across groups for financial knowledge, attitudes, and practice adoption suggest that these messages were

\footnotetext{
${ }^{19}$ We were not able to use administrative data to analyze heterogeneous effects of other socio-demographic variables for formal savings since the individual data was anonymous below the cluster or municipal level. We analyzed heterogeneous effects with the credit administrative data, but we did not find any differential effect of the intervention on credit outcomes that survived the multiple hypothesis test correction
} 
socialized and internalized. While the SMS messages may have increased knowledge and savings at the intensive margins, the bulk of the impact was generated by having access to the tablet 20 . What remains unknown is which content in the LISTA app worked best individually or together and why.

Social learning within the household. One reason Fundación Capital selected the tablet rotation methodology was because it allowed users to bring the tablet into their homes. The program confirmed reaching 100,000 registered CCT users, yet at the end of the program over 160,000 individuals had registered on the tablets, as it was common for family members and friends to create their own profiles. Qualitative interviews likewise suggest the tablets were a novelty when brought into the home and it was common for mothers to share them with partners, children, and other household members, thus generating conversations within the family, which may have continued after the tablet passed to the next user. An open question is how much the family-centered nature of this learning reinforced knowledge acquisition, practice adoption, and improved performance after the intervention.

Channel. The use of the mother leader as a near-peer who brought the tablet to the end-users appears as a third mechanism. This might have driven impact in two ways. First, trust in the mother leader may have increased adoption and openness to the messaging. This is supported by qualitative interviews during the pilot phase and the process evaluation, and, more importantly, with detection of a positive and statistically significant link between quality of the relationship with the mother leader and beneficiary outcomes, as reported by the user during the second inperson follow-up. We hypothesize that (a) the closeness of the relationship with the mother leader increases not only the likelihood of receiving the tablet, but the amount of time spent on it, and (b) the time of use or intensity further predicts outcomes.

Social learning within the community. Another channel of impact involves the network of (mostly female) beneficiaries, with whom the mother leader often communicates en masse via mobile phone or by convening meetings. The process evaluation revealed that it was common for mother leaders to conduct trainings by inviting mothers to her home or another space where they trained as a group and discussed content. As with the social learning generated within the household, knowledge and attitude acquisition may have continued afterward within peer networks (mothers and households), especially as tablets rotated among beneficiaries within the municipality over several months. The aforementioned results on ATM accompaniment withdrawal practices and the teaching of ATM may reflect such a social learning component at work.

Barriers to formal financial system access. As can be inferred from the main results and

\footnotetext{
${ }^{20}$ See section 8 of the Supplemental Document for SMS results. Respondents were also asked during the in-person second follow-up survey about use of the LISTA Kit, including the calendar and stickers which reiterated the tablet messaging. In most cases these materials were not actively used and, instead, were stored in non-visible places as observed during the in-person second follow-up.
} 
heterogeneous effects, the major barrier to formal savings and deeper financial inclusion across product types does not appear to be an issue of trust alone. In the short-, medium-, and longterm, the preference for safekeeping cash in banks maintained statistical significance. In terms of practices, over the short-term members of the treatment group expressed an openness to leaving money in the account and saving in the bank, as evidenced by both self-reported and bank administrative data. Yet overall this impact was lost in the medium-term, with marginal significance in the long-term for whether people save formally. The heterogeneity of positive effects concentrated in the Caribbean, with negative effects in the Pacific. Furthermore, the lack of effects in the formal market among the rural population suggest that geographical access and product design may be the biggest barriers. While in the Caribbean, transactionality decreased, it increased in the Pacific according to the short-term bank administrative data. Yet overall in the long-term, use of formal credit decreased. Even though data are still lacking for testing further hypotheses, the use of less credit is aligned with the ability to save and manage better their own finances. A structural analysis of the supply and demand factors at play in this intervention, something that to our knowledge has not been attempted in the field of financial inclusion, may shed light on these unanswered questions.

In sum, future evaluations could disaggregate these mechanisms, while further structural modeling of the data, which would move beyond the reduced form analysis used here, could add insights into learning processes.

\section{Conclusion}

Evaluation results suggest that it is possible to design and deliver an impactful, cost-effective, and scalable digital-based financial education program for lower-income CCT recipients. When the content is presented in a simplified and gamified way, includes relevant and motivating content, and is aligned with government social protection strategies, financial knowledge can be improved, increasing financial health in the long-term, benefiting the poorest women at low cost 21 .

On average, members of the treatment group created financial systems, undergirded largely by savings and budgeting practices, which positively influenced their spending, saving, borrowing, and planning. Such outcomes reflect increased financial health (CSFI, 2017). Nevertheless, understanding how to move from these outcomes to formal financial inclusion, especially in relation to saving, credit, and insurance products, requires more analysis. Just as banking alone is not enough, neither is a demand-side financial education intervention. To use a popular Marshallian metaphor, for the scissors to cut, both blades - supply and demand - are needed. Increasing the financial inclusion and, by extension, the financial health of the most vulnerable requires both. Regardless, this evidence demonstrates that a well-designed digital-based programs that takes into consideration content, channel, and social learning within and between households could help.

\footnotetext{
${ }^{21}$ When massively deployed, the LISTA intervention can create economies of scale, dramatically decreasing cost per person. Fundación Capital calculated that once completed, the LISTA program in Colombia cost US\$6-9 per user, a significant savings from the US $\$ 22$ per person of the pilot intervention or the US $\$ 40$ of in-person training.
} 


\section{References}

Almås, I., Armand, A., Attanasio, O., and Carneiro, P. (2018). Measuring and changing control: Women's empowerment and targeted transfers. The Economic Journal, 128(612):F609-F639.

Ashraf, N., Karlan, D., and Yin, W. (2006). Tying odysseus to the mast: Evidence from a commitment savings product in the Philippines. The Quarterly Journal of Economics, 121(2):635-672.

Attanasio, O., Fernández, C., Fitzsimons, E., Grantham-McGregor, S., Meghir, C., and RubioCodina, M. (2014). Using the infrastructure of a conditional cash transfer program to deliver a scalable integrated early child development program in Colombia: cluster randomized controlled trial. BMJ, 349:g5785.

Attanasio, O. and Mesnard, A. (2006). The impact of a conditional cash transfer programme on consumption in Colombia. Fiscal Studies, 27(4):421-442.

Banerjee, A., Karlan, D., and Zinman, J. (2015). Six randomized evaluations of microcredit: Introduction and further steps. American Economic Journal: Applied Economics, 7(1):1-21.

Bastagli, F., Hagen-Zanker, J., Harman, L., Barca, V., Sturge, G., Schmidt, T., and Pellerano, L. (2016). Cash transfers: what does the evidence say. a rigorous review of programme impact and the role of design and implementation features. London: Overseas Development Institute.

Bateman, M., Blankenburg, S., and Kozul-Wright, R., editors (2018). The Rise and Fall of Global Microcredit. Routledge.

Berg, G. and Zia, B. (2017). Harnessing emotional connections to improve financial decisions: Evaluating the impact of financial education in mainstream media. Journal of the European Economic Association, 15(5):1025-1055.

Beshears, J., Choi, J., Laibson, D., Madrian, B., and Milkman, K. (2015). The effect of providing peer information on retirement savings decisions. The Journal of Finance, 70(3):1161-1201.

Blumenstock, J., Callen, M., and Ghani, T. (2018). Why do defaults affect behavior? experimental evidence from afghanistan. American Economic Review, 108(10):2868-2901.

Brune, L., Giné, X., Goldberg, J., and Yang, D. (2017). Savings defaults and payment delays for cash transfers: Field experimental evidence from Malawi. Journal of Development Economics, 129:1-13.

Bucher-Koenen, T., Lusardi, A., Alessie, R., and Van Rooij, M. (2017). How financially literate are women? an overview and new insights. Journal of Consumer Affairs, 51(2):255-283.

Bulte, C., Betts, A., Garner, K., and Durning, S. (2007). Student teaching: views of student near-peer teachers and learners. Medical Teacher, 29(6):583-590. 
Cardona, L., Medina, C., and Nuñez, J. (2017). Impacto de las transferencias condicionadas sobre el mercado de crédito: el caso de Familias en Acción en Colombia. In Tamayo, C. and Malagón, J., editors, Ensayos sobre inclusión financiera en Colombia. Bogotá: Banco Interamericano de Desarrollo y Asobancaria.

Carpena, F., Cole, S., Shapiro, J., and Zia, B. (2017). The ABCs of financial education: experimental evidence on attitudes, behavior, and cognitive biases. Management Science, Articles in Advance:1-24.

Center for Financial Services Innovation (CSFI) (2017). Beyond financial inclusion: Financial health as a global framework. Chicago: Center for Financial Services Innovation and Center for Financial Inclusion at Accion.

Chong, A. and Ferrara, E. (2009). Television and divorce: Evidence from brazilian novelas. Journal of the European Economic Association, 7(2-3):458-468.

Cohen, M. and Nelson, C. (2011). Financial literacy: A step for clients towards financial inclusion. Global Microcredit Summit, pages 14-17.

Collins, D., Morduch, J., Rutherford, S., and Ruthven, O. (2009). Portfolios of the Poor: How the World's Poor Live on a Day. Princenton, USA: Princeton University Press.

Deb, A. and Kubzansky, M. (2012). Bridging the gap: The business case for financial literacy. Citi Foundation.

Demirguc-Kunt, A., Klapper, L., and Singer, D. (2017). Financial inclusion and inclusive growth: a review of recent empirical evidence. Policy Research Working Paper Series 8040, The World Bank.

Drexler, A., Fischer, G., and Schoar, A. (2014). Keeping it simple: Financial literacy and rules of thumb. American Economic Journal: Applied Economics, 6(2):1-31.

Duflo, E. (2012). Women empowerment and economic development. Journal of Economic Literature, 50(4):1051-79.

Duflo, E., Kremer, M., and Robinson, J. (2011). Nudging farmers to use fertilizer: Theory and experimental evidence from Kenya. American Economic Review, 101(6):2350-90.

Duflo, E. and Saez, E. (2003). The role of information and social interactions in retirement plan decisions: Evidence from a randomized experiment. The Quarterly Journal of Economics, 118(3):815842.

Dupas, P., Karlan, D., Robinson, J., and Ubfal, D. (2018). Banking the unbanked? Evidence from three countries. American Economic Journal: Applied Economics, 10(2):257-97. 
Dupas, P. and Robinson, J. (2013). Savings constraints and microenterprise development: Evidence from a field experiment in Kenya. American Economic Journal: Applied Economics, 5(1):163-92.

Edge Finance (2007). El proyecto capital: Proyecto de capitalización y reducción de la vulnerabilidad de los pobres (protección social y formación de activos para las familias vulnerables). Technical report.

Fernandes, D., Lynch Jr, J., and Netemeyer, R. (2014). Financial literacy, financial education, and downstream financial behaviors. Management Science, 60(8):1861-1883.

FIDA (2004a). Diez claves de éxito para el desarrollo rural: basadas en las experiencias de los proyectos feas, marenass, corredor, y sierra sur. Technical report, Fondo Internacional para el Desarrollo Agrícola.

FIDA (2004b). Experiencias innovadoras en los proyectos del FIDA en la República del Perú. Technical report, Informe 1497-PE, Fondo Internacional para el Desarrollo Agrícola.

Fort, M., Manaresi, F., and Trucchi, S. (2016). Adult financial literacy and households financial assets: the role of bank information policies. Economic Policy, 31(88):743-782.

Garg, N. and Lerner, J. S. (2013). Sadness and consumption. Journal of Consumer Psychology, 23(1):106-113.

Gertler, P. (2004). Do conditional cash transfers improve child health? Evidence from PROGRESA's control randomized experiment. American Economic Review, 94(2):336-341.

Gine, X., Martinez Cuellar, C., and Mazer, R. K. (2014). Financial (dis-) information: evidence from an audit study in Mexico. The World Bank.

Guérin, I., Labie, M., and Servet, J.-M. (2015). The crises of microcredit. University of Chicago Press.

Handa, S. and Davis, B. (2006). The experience of conditional cash transfers in Latin America and the Caribbean. Development Policy Review, 24(5):513-536.

Hastings, J. S., Madrian, B. C., and Skimmyhorn, W. L. (2013). Financial literacy, financial education, and economic outcomes. Annu. Rev. Econ., 5(1):347-373.

Herzberg, P. Y., Glaesmer, H., and Hoyer, J. (2006). Separating optimism and pessimism: a robust psychometric analysis of the revised Life Orientation Test (LOT-R). Psychological Assessment, $18(4): 433$.

Hsiaw, A. (2013). Goal-setting and self-control. Journal of Economic Theory, 148(2):601-626.

Hubbard, R. G., Skinner, J., and Zeldes, S. P. (1995). Precautionary saving and social insurance. Journal of political Economy, 103(2):360-399. 
Jappelli, T. and Padula, M. (2013). Investment in financial literacy and saving decisions. Journal of Banking \& Finance, 37(8):2779-2792.

Kaiser, T. and Menkhoff, L. (2017). Does financial education impact financial literacy and financial behavior, and if so, when? The World Bank.

Karlan, D., Kendall, J., Mann, R., Pande, R., Suri, T., and Zinman, J. (2016a). Research and impacts of digital financial services. Technical report, National Bureau of Economic Research.

Karlan, D., McConnell, M., Mullainathan, S., and Zinman, J. (2016b). Getting to the top of mind: How reminders increase saving. Management Science, 62(12):3393-3411.

Karlan, D. and Morduch, J. (2010). Access to finance. In Rodrik, D. and Rosenzweig, M., editors, Handbook of development economics, volume 5, pages 4703-4784. Elsevier.

Karlan, D., Ratan, A. L., and Zinman, J. (2014). Savings by and for the poor: A research review and agenda. Review of Income and Wealth, 60(1):36-78.

Kemper, C., Kovaleva, A., Beierlein, C., and Rammstedt, B. (2011). Measuring the construct of optimism-pessimism with single item indicators. In 4 th conference of the European Survey Research Association (ESRA), Lausanne, Switzerland.

Kolb, D. A. (2014). Experiential learning: Experience as the source of learning and development. FT press.

La Ferrara, E., Chong, A., and Duryea, S. (2012). Soap operas and fertility: Evidence from Brazil. American Economic Journal: Applied Economics, 4(4):1-31.

Lerner, J., Li, Y., and Weber, E. (2013). The financial costs of sadness. Psychological Science, $24(1): 72-79$.

Lerner, J., Loewenstein, G., and Small, D. (2004). Heart strings and purse strings: Carryover effects of emotions on economic decisions. Psychological Science, 15(5):337-341.

Lerner, J. S. and Keltner, D. (2001). Fear, anger, and risk. Journal of personality and social psychology, 81(1):146.

Lusardi, A., Michaud, P.-C., and Mitchell, O. (2017). Optimal financial knowledge and wealth inequality. Journal of Political Economy, 125(2):431-477.

Lusardi, A. and Mitchell, O. S. (2014). The economic importance of financial literacy: Theory and evidence. Journal of economic literature, 52(1):5-44.

Mader, P. (2015). The Political Economy of Microfinance. The financializaton of poverty. Springer.

Maldonado, J. H., editor (2018). Proyecto Capital: diez años vinculando la inclusión financiera con la protección social. Fundación Capital, Instituto de Estudios Peruanos. 
McConnell, B. and Vera-Hernández, M. (2015). Going beyond simple sample size calculations: A practitioner's guide. Technical report, IFS Working Papers.

McKenzie, D. (2012). Beyond baseline and follow-up: The case for more $t$ in experiments. Journal of Development Economics, 99(2):210-221.

Miller, M., Reichelstein, J., Salas, C., and Zia, B. (2015). Can you help someone become financially capable? A meta-analysis of the literature. The World Bank Research Observer, 30(2):220-246.

Morduch, J. (1995). Income smoothing and consumption smoothing. Journal of Economic Perspectives, 9(3):103-114.

Morduch, J. and Roodman, D. (2014). The impact of microcredit on the poor in bangladesh: Revisiting the evidence. Journal of Development Studies, 50(4):583-604.

Pantelić, A. (2011). A comparative analysis of microfinance and conditional cash transfers in latin america. Development in Practice, 21(6):790-805.

Pornpitakpan, C. (2006). The persuasiveness of source credibility: A critical review of five decades' evidence. Journal of Applied Social Psychology, 34(2):243-281.

Prabhakar, R. (2018). Financial inclusion: A tale of two literatures. Social Policy and Society, pages $1-14$.

Romano, J. P. and Wolf, M. (2005). Stepwise multiple testing as formalized data snooping. Econometrica, 73(4):1237-1282.

Schaner, S. (2018). The persistent power of behavioral change: Long-run impacts of temporary savings subsidies for the poor. American Economic Journal: Applied Economics, 10(3):67-100.

Seshan, G. and Yang, D. (2012). Transnational household finance: A field experiment on the crossborder impacts of financial education for migrant workers. In Qatar Foundation Annual Research Forum Proceedings.

Soman, D. and Zhao, M. (2011). The fewer the better: Number of goals and savings behavior. Journal of Marketing Research, 48(6):944-957.

Terrion, J. L. and Leonard, D. (2007). A taxonomy of the characteristics of student peer mentors in higher education: Findings from a literature review. Mentoring \& Tutoring, 15(2):149-164.

Tulving, E. (2002). Episodic memory: From mind to brain. Annual Review of Psychology, 53(1):125.

Ülkümen, G. and Cheema, A. (2011). Framing goals to influence personal savings: The role of specificity and construal level. Journal of Marketing Research, 48(6):958-969.

Willis, L. E. (2011). The financial education fallacy. American Economic Review, 101(3):429-34. 


\section{Appendices}

\section{A LISTA Application}
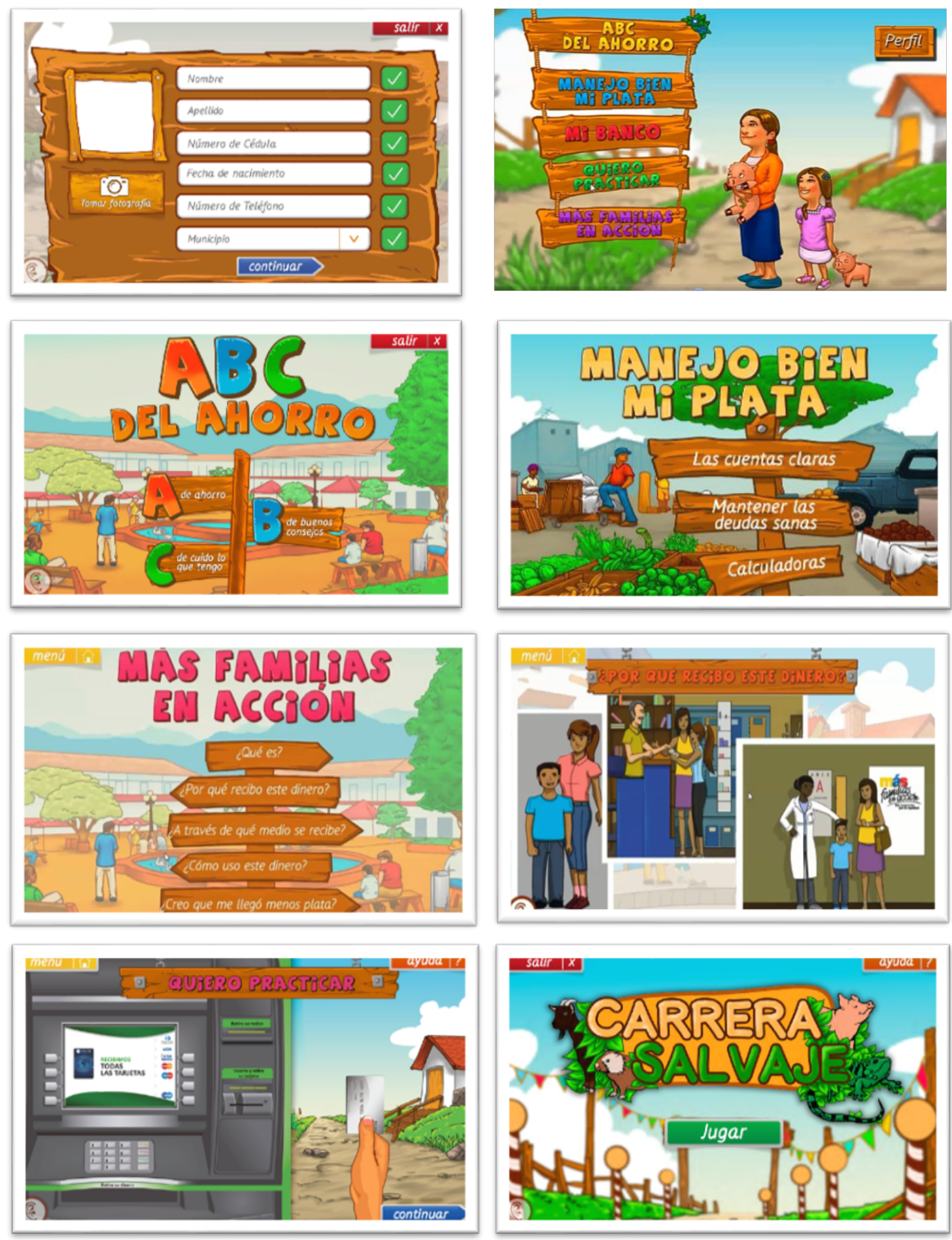


\section{B Randomization Map}

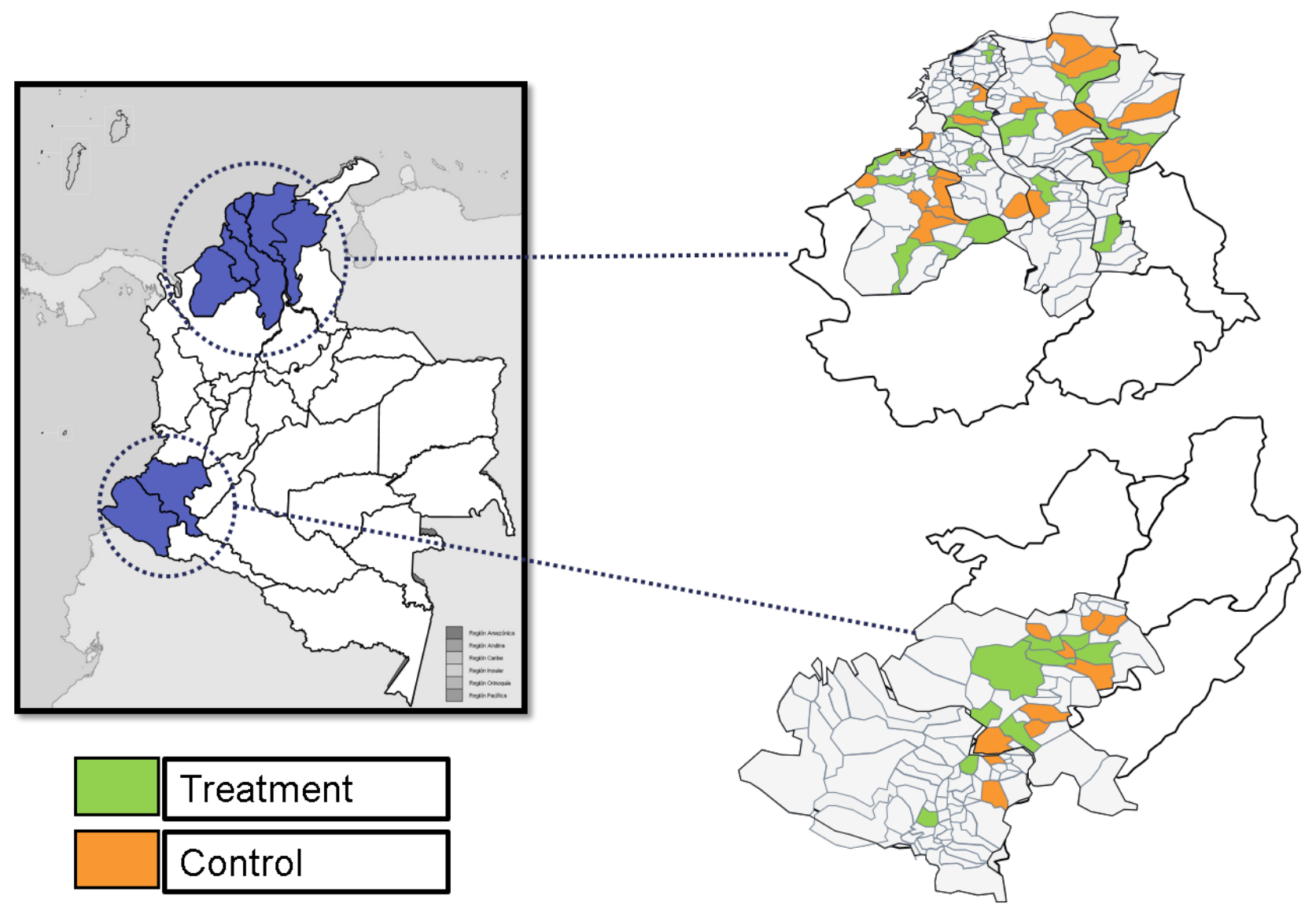

\section{Intervention Timeline}

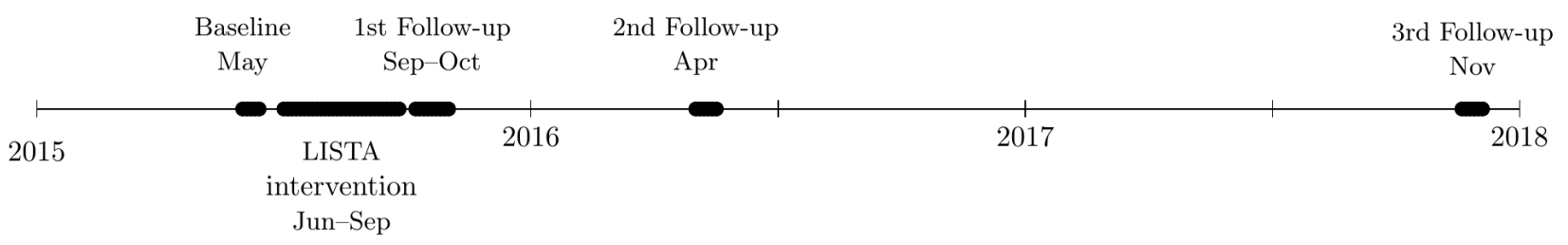




\title{
Freeing Financial Education via Tablets: Experimental Evidence from Colombia Supplementary Material
}

\author{
Orazio Attanasio Matthew Bird Lina Cardona Pablo Lavado
}

May 28, 2019 


\section{Attrition Analysis}

Table 1: Attrition between baseline and 1st follow-up

\begin{tabular}{|c|c|c|c|c|c|c|c|c|c|c|c|c|}
\hline & \multicolumn{12}{|c|}{ Dependent variable: attrited between baseline and first follow-up } \\
\hline & $(1)$ & $(2)$ & $(3)$ & $(4)$ & $(5)$ & $(6)$ & $(7)$ & $(8)$ & (9) & $(10)$ & $(11)$ & $(12)$ \\
\hline Treatment & $\begin{array}{c}-0.011 \\
(0.069)\end{array}$ & $\begin{array}{c}-0.011 \\
(0.069)\end{array}$ & $\begin{array}{c}-0.011 \\
(0.069)\end{array}$ & $\begin{array}{c}-0.011 \\
(0.069)\end{array}$ & $\begin{array}{c}-0.014 \\
(0.069)\end{array}$ & $\begin{array}{c}-0.014 \\
(0.069)\end{array}$ & $\begin{array}{c}-0.016 \\
(0.069)\end{array}$ & $\begin{array}{c}-0.022 \\
(0.069)\end{array}$ & $\begin{array}{c}-0.021 \\
(0.065)\end{array}$ & $\begin{array}{c}-0.024 \\
(0.066)\end{array}$ & $\begin{array}{c}-0.018 \\
(0.066)\end{array}$ & $\begin{array}{c}-0.017 \\
(0.066)\end{array}$ \\
\hline Children in hh & $\begin{array}{l}-0.014 \\
(0.018)\end{array}$ & $\begin{array}{l}-0.014 \\
(0.018)\end{array}$ & $\begin{array}{l}-0.011 \\
(0.018)\end{array}$ & $\begin{array}{c}0.006 \\
(0.026)\end{array}$ & $\begin{array}{c}0.004 \\
(0.026)\end{array}$ & $\begin{array}{c}0.004 \\
(0.026)\end{array}$ & $\begin{array}{c}0.003 \\
(0.026)\end{array}$ & $\begin{array}{c}0.034 \\
(0.036)\end{array}$ & $\begin{array}{c}0.037 \\
(0.036)\end{array}$ & $\begin{array}{c}0.026 \\
(0.035)\end{array}$ & $\begin{array}{c}0.023 \\
(0.035)\end{array}$ & $\begin{array}{c}0.024 \\
(0.035)\end{array}$ \\
\hline Someone works in hh & & $\begin{array}{l}-0.001 \\
(0.075)\end{array}$ & $\begin{array}{c}0.036 \\
(0.087)\end{array}$ & $\begin{array}{l}0.016 \\
(0.094)\end{array}$ & $\begin{array}{c}0.030 \\
(0.095)\end{array}$ & $\begin{array}{c}0.029 \\
(0.095)\end{array}$ & $\begin{array}{c}0.033 \\
(0.094)\end{array}$ & $\begin{array}{c}0.051 \\
(0.095)\end{array}$ & $\begin{array}{c}0.061 \\
(0.095)\end{array}$ & $\begin{array}{c}0.055 \\
(0.095)\end{array}$ & $\begin{array}{c}0.057 \\
(0.097)\end{array}$ & $\begin{array}{c}0.059 \\
(0.097)\end{array}$ \\
\hline People working in hh & & & $\begin{array}{l}-0.023 \\
(0.026)\end{array}$ & $\begin{array}{l}-0.008 \\
(0.029)\end{array}$ & $\begin{array}{l}-0.010 \\
(0.029)\end{array}$ & $\begin{array}{l}-0.009 \\
(0.028)\end{array}$ & $\begin{array}{l}-0.009 \\
(0.028)\end{array}$ & $\begin{array}{l}-0.016 \\
(0.028)\end{array}$ & $\begin{array}{l}-0.009 \\
(0.027)\end{array}$ & $\begin{array}{l}-0.011 \\
(0.027)\end{array}$ & $\begin{array}{l}-0.012 \\
(0.027)\end{array}$ & $\begin{array}{l}-0.011 \\
(0.027)\end{array}$ \\
\hline Number of hh members & & & & $\begin{array}{l}-0.017 \\
(0.018)\end{array}$ & $\begin{array}{l}-0.017 \\
(0.018)\end{array}$ & $\begin{array}{l}-0.017 \\
(0.018)\end{array}$ & $\begin{array}{l}-0.020 \\
(0.018)\end{array}$ & $\begin{array}{l}-0.022 \\
(0.018)\end{array}$ & $\begin{array}{l}-0.023 \\
(0.018)\end{array}$ & $\begin{array}{l}-0.018 \\
(0.018)\end{array}$ & $\begin{array}{l}-0.018 \\
(0.018)\end{array}$ & $\begin{array}{l}-0.018 \\
(0.018)\end{array}$ \\
\hline Urban & & & & & $\begin{array}{l}-0.122^{*} \\
(0.070)\end{array}$ & $\begin{array}{c}-0.121^{*} \\
(0.069)\end{array}$ & $\begin{array}{l}-0.110 \\
(0.069)\end{array}$ & $\begin{array}{l}-0.114^{*} \\
(0.069)\end{array}$ & $\begin{array}{l}-0.098 \\
(0.067)\end{array}$ & $\begin{array}{l}-0.090 \\
(0.066)\end{array}$ & $\begin{array}{l}-0.086 \\
(0.066)\end{array}$ & $\begin{array}{l}-0.087 \\
(0.066)\end{array}$ \\
\hline Sex & & & & & & $\begin{array}{l}-0.023 \\
(0.079)\end{array}$ & $\begin{array}{l}-0.022 \\
(0.080)\end{array}$ & $\begin{array}{l}-0.006 \\
(0.080)\end{array}$ & $\begin{array}{c}0.001 \\
(0.079)\end{array}$ & $\begin{array}{l}-0.011 \\
(0.080)\end{array}$ & $\begin{array}{c}0.001 \\
(0.081)\end{array}$ & $\begin{array}{c}0.013 \\
(0.083)\end{array}$ \\
\hline Years of schooling & & & & & & & $\begin{array}{l}-0.008 \\
(0.006)\end{array}$ & $\begin{array}{l}-0.010 \\
(0.006)\end{array}$ & $\begin{array}{l}-0.010 \\
(0.007)\end{array}$ & $\begin{array}{c}-0.017^{* *} \\
(0.007)\end{array}$ & $\begin{array}{c}-0.017^{* *} \\
(0.007)\end{array}$ & $\begin{array}{c}-0.016^{* *} \\
(0.007)\end{array}$ \\
\hline Age of MFA beneficiaries & & & & & & & & $\begin{array}{l}-0.051 \\
(0.037)\end{array}$ & $\begin{array}{l}-0.061 \\
(0.038)\end{array}$ & $\begin{array}{c}-0.063^{*} \\
(0.038)\end{array}$ & $\begin{array}{l}-0.051 \\
(0.038)\end{array}$ & $\begin{array}{l}-0.052 \\
(0.038)\end{array}$ \\
\hline Banco Agrario & & & & & & & & & $\begin{array}{c}0.269^{* *} \\
(0.118)\end{array}$ & $\begin{array}{c}0.250^{* *} \\
(0.118)\end{array}$ & $\begin{array}{c}0.300^{* *} \\
(0.119)\end{array}$ & $\begin{array}{c}0.298^{* *} \\
(0.119)\end{array}$ \\
\hline Age & & & & & & & & & & $\begin{array}{c}-0.007^{* *} \\
(0.003)\end{array}$ & $\begin{array}{c}-0.007 * * \\
(0.003)\end{array}$ & $\begin{array}{c}-0.006^{* *} \\
(0.003)\end{array}$ \\
\hline Account type (deposit) & & & & & & & & & & & $\begin{array}{c}-0.190^{* *} \\
(0.081)\end{array}$ & $\begin{array}{c}-0.183^{* *} \\
(0.081)\end{array}$ \\
\hline Mujeres ahorradoras & & & & & & & & & & & & $\begin{array}{c}-0.137^{*} \\
(0.082)\end{array}$ \\
\hline Observations & 3,126 & 3,126 & 3,126 & 3,125 & 3,117 & 3,117 & 3,117 & 3,105 & 3,105 & 3,105 & 3,105 & 3,105 \\
\hline
\end{tabular}

Note: Coefficients and clustered standard errors (in parentheses) from a probit regression where the dependent variable is an indicator of whether the beneficiary attried or not. ${ }^{* * *} \mathrm{p}<0.01,{ }^{* *} \mathrm{p}<0.05,{ }^{*} \mathrm{p}<0.1$ 
Table 2: Attrition between baseline and 2nd follow-up

\begin{tabular}{|c|c|c|c|c|c|c|c|c|c|c|c|c|}
\hline & \multicolumn{12}{|c|}{ Dependent variable: attrited between baseline and second follow-up } \\
\hline & (1) & $(2)$ & $(3)$ & $(4)$ & $(5)$ & $(6)$ & $(7)$ & (8) & (9) & $(10)$ & $(11)$ & $(12)$ \\
\hline Treatment & $\begin{array}{c}-0.052 \\
(0.054)\end{array}$ & $\begin{array}{c}-0.054 \\
(0.054)\end{array}$ & $\begin{array}{c}-0.054 \\
(0.054)\end{array}$ & $\begin{array}{c}-0.054 \\
(0.054)\end{array}$ & $\begin{array}{c}-0.050 \\
(0.053)\end{array}$ & $\begin{array}{c}-0.052 \\
(0.052)\end{array}$ & $\begin{array}{c}-0.050 \\
(0.052)\end{array}$ & $\begin{array}{c}-0.055 \\
(0.052)\end{array}$ & $\begin{array}{c}-0.056 \\
(0.052)\end{array}$ & $\begin{array}{c}-0.059 \\
(0.053)\end{array}$ & $\begin{array}{c}-0.050 \\
(0.053)\end{array}$ & $\begin{array}{c}-0.048 \\
(0.053)\end{array}$ \\
\hline Children in hh & $\begin{array}{c}0.002 \\
(0.018)\end{array}$ & $\begin{array}{c}0.004 \\
(0.018)\end{array}$ & $\begin{array}{c}0.008 \\
(0.019)\end{array}$ & $\begin{array}{l}-0.022 \\
(0.034)\end{array}$ & $\begin{array}{l}-0.025 \\
(0.035)\end{array}$ & $\begin{array}{l}-0.024 \\
(0.035)\end{array}$ & $\begin{array}{l}-0.021 \\
(0.035)\end{array}$ & $\begin{array}{c}0.033 \\
(0.043)\end{array}$ & $\begin{array}{c}0.033 \\
(0.044)\end{array}$ & $\begin{array}{c}0.020 \\
(0.044)\end{array}$ & $\begin{array}{c}0.020 \\
(0.044)\end{array}$ & $\begin{array}{c}0.022 \\
(0.044)\end{array}$ \\
\hline Someone works in hh & & $\begin{array}{l}-0.076 \\
(0.064)\end{array}$ & $\begin{array}{l}-0.021 \\
(0.082)\end{array}$ & $\begin{array}{c}0.015 \\
(0.091)\end{array}$ & $\begin{array}{c}0.033 \\
(0.092)\end{array}$ & $\begin{array}{c}0.030 \\
(0.093)\end{array}$ & $\begin{array}{c}0.024 \\
(0.093)\end{array}$ & $\begin{array}{c}0.038 \\
(0.091)\end{array}$ & $\begin{array}{c}0.038 \\
(0.091)\end{array}$ & $\begin{array}{c}0.031 \\
(0.093)\end{array}$ & $\begin{array}{c}0.032 \\
(0.092)\end{array}$ & $\begin{array}{c}0.035 \\
(0.092)\end{array}$ \\
\hline People working in hh & & & $\begin{array}{l}-0.033 \\
(0.031)\end{array}$ & $\begin{array}{l}-0.059 \\
(0.038)\end{array}$ & $\begin{array}{c}-0.063^{*} \\
(0.038)\end{array}$ & $\begin{array}{c}-0.063^{*} \\
(0.038)\end{array}$ & $\begin{array}{l}-0.062 \\
(0.038)\end{array}$ & $\begin{array}{c}-0.073^{* *} \\
(0.037)\end{array}$ & $\begin{array}{c}-0.073^{* *} \\
(0.037)\end{array}$ & $\begin{array}{c}-0.074^{* *} \\
(0.038)\end{array}$ & $\begin{array}{c}-0.076^{* *} \\
(0.038)\end{array}$ & $\begin{array}{c}-0.075^{* *} \\
(0.038)\end{array}$ \\
\hline Number of hh members & & & & $\begin{array}{c}0.029 \\
(0.022)\end{array}$ & $\begin{array}{c}0.028 \\
(0.022)\end{array}$ & $\begin{array}{c}0.029 \\
(0.022)\end{array}$ & $\begin{array}{c}0.031 \\
(0.022)\end{array}$ & $\begin{array}{c}0.023 \\
(0.022)\end{array}$ & $\begin{array}{c}0.023 \\
(0.022)\end{array}$ & $\begin{array}{c}0.030 \\
(0.022)\end{array}$ & $\begin{array}{c}0.029 \\
(0.022)\end{array}$ & $\begin{array}{c}0.028 \\
(0.022)\end{array}$ \\
\hline Urban & & & & & $\begin{array}{c}-0.145^{* * *} \\
(0.048)\end{array}$ & $\begin{array}{c}-0.141^{* * *} \\
(0.049)\end{array}$ & $\begin{array}{c}-0.152^{* * *} \\
(0.050)\end{array}$ & $\begin{array}{c}-0.155^{* * *} \\
(0.051)\end{array}$ & $\begin{array}{c}-0.155^{* * *} \\
(0.051)\end{array}$ & $\begin{array}{c}-0.146^{* * *} \\
(0.051)\end{array}$ & $\begin{array}{c}-0.149^{* * *} \\
(0.051)\end{array}$ & $\begin{array}{c}-0.149^{* * *} \\
(0.052)\end{array}$ \\
\hline Sex & & & & & & $\begin{array}{l}-0.106 \\
(0.079)\end{array}$ & $\begin{array}{l}-0.108 \\
(0.080)\end{array}$ & $\begin{array}{l}-0.076 \\
(0.079)\end{array}$ & $\begin{array}{l}-0.076 \\
(0.079)\end{array}$ & $\begin{array}{l}-0.093 \\
(0.079)\end{array}$ & $\begin{array}{l}-0.078 \\
(0.078)\end{array}$ & $\begin{array}{l}-0.061 \\
(0.078)\end{array}$ \\
\hline Years of schooling & & & & & & & $\begin{array}{c}0.010 \\
(0.006)\end{array}$ & $\begin{array}{c}0.007 \\
(0.006)\end{array}$ & $\begin{array}{c}0.007 \\
(0.006)\end{array}$ & $\begin{array}{l}-0.001 \\
(0.006)\end{array}$ & $\begin{array}{c}0.000 \\
(0.006)\end{array}$ & $\begin{array}{c}0.001 \\
(0.006)\end{array}$ \\
\hline Age of MFA beneficiaries & & & & & & & & $\begin{array}{c}-0.091^{* * *} \\
(0.032)\end{array}$ & $\begin{array}{c}-0.090^{* * * *} \\
(0.033)\end{array}$ & $\begin{array}{c}-0.093^{* * *} \\
(0.033)\end{array}$ & $\begin{array}{c}-0.080 * * \\
(0.033)\end{array}$ & $\begin{array}{c}-0.082^{* *} \\
(0.033)\end{array}$ \\
\hline Banco Agrario & & & & & & & & & $\begin{array}{l}-0.018 \\
(0.075)\end{array}$ & $\begin{array}{l}-0.042 \\
(0.077)\end{array}$ & $\begin{array}{c}0.027 \\
(0.068)\end{array}$ & $\begin{array}{c}0.023 \\
(0.068)\end{array}$ \\
\hline Age & & & & & & & & & & $\begin{array}{c}-0.008^{* * *} \\
(0.003)\end{array}$ & $\begin{array}{c}-0.008^{* * *} \\
(0.003)\end{array}$ & $\begin{array}{c}-0.007^{* * *} \\
(0.003)\end{array}$ \\
\hline Account type (deposit) & & & & & & & & & & & $\begin{array}{c}-0.225^{* * *} \\
(0.076)\end{array}$ & $\begin{array}{c}-0.214^{* * *} \\
(0.076)\end{array}$ \\
\hline Mujeres ahorradoras & & & & & & & & & & & & $\begin{array}{c}-0.187^{*} \\
(0.105)\end{array}$ \\
\hline Observations & 3,126 & 3,126 & 3,126 & 3,125 & 3,117 & 3,117 & 3,117 & 3,105 & 3,105 & 3,105 & 3,105 & 3,105 \\
\hline
\end{tabular}

Note: Coefficients and clustered standard errors (in parentheses) from a probit regression where the dependent variable is an indicator of whether the

beneficiary attried or not. ${ }^{* * *} \mathrm{p}<0.01,{ }^{* *} \mathrm{p}<0.05,{ }^{*} \mathrm{p}<0.1$ 
Table 3: Attrition between baseline and 3rd follow-up

\begin{tabular}{|c|c|c|c|c|c|c|c|c|c|c|c|c|}
\hline & \multicolumn{12}{|c|}{ Dependent variable: attrited between baseline and third follow-up } \\
\hline & $(1)$ & $(2)$ & $(3)$ & $(4)$ & $(5)$ & $(6)$ & $(7)$ & $(8)$ & $(9)$ & $(10)$ & $(11)$ & $(12)$ \\
\hline Treatment & $\begin{array}{c}0.023 \\
(0.072)\end{array}$ & $\begin{array}{c}0.022 \\
(0.073)\end{array}$ & $\begin{array}{c}0.021 \\
(0.073)\end{array}$ & $\begin{array}{c}0.021 \\
(0.074)\end{array}$ & $\begin{array}{c}0.023 \\
(0.073)\end{array}$ & $\begin{array}{c}0.022 \\
(0.073)\end{array}$ & $\begin{array}{c}0.020 \\
(0.073)\end{array}$ & $\begin{array}{c}0.011 \\
(0.072)\end{array}$ & $\begin{array}{c}0.012 \\
(0.070)\end{array}$ & $\begin{array}{c}0.009 \\
(0.070)\end{array}$ & $\begin{array}{c}0.020 \\
(0.069)\end{array}$ & $\begin{array}{c}0.022 \\
(0.070)\end{array}$ \\
\hline Children in hh & $\begin{array}{c}0.016 \\
(0.018)\end{array}$ & $\begin{array}{c}0.017 \\
(0.018)\end{array}$ & $\begin{array}{c}0.022 \\
(0.017)\end{array}$ & $\begin{array}{c}0.057^{* *} \\
(0.027)\end{array}$ & $\begin{array}{c}0.054^{* *} \\
(0.027)\end{array}$ & $\begin{array}{c}0.055^{* *} \\
(0.027)\end{array}$ & $\begin{array}{l}0.052^{*} \\
(0.027)\end{array}$ & $\begin{array}{l}0.057^{*} \\
(0.034)\end{array}$ & $\begin{array}{l}0.059^{*} \\
(0.034)\end{array}$ & $\begin{array}{c}0.043 \\
(0.034)\end{array}$ & $\begin{array}{c}0.041 \\
(0.034)\end{array}$ & $\begin{array}{c}0.043 \\
(0.034)\end{array}$ \\
\hline Someone works in hh & & $\begin{array}{l}-0.043 \\
(0.081)\end{array}$ & $\begin{array}{c}0.033 \\
(0.095)\end{array}$ & $\begin{array}{c}-0.007 \\
(0.102)\end{array}$ & $\begin{array}{c}0.004 \\
(0.102)\end{array}$ & $\begin{array}{c}0.002 \\
(0.102)\end{array}$ & $\begin{array}{c}0.008 \\
(0.101)\end{array}$ & $\begin{array}{c}0.000 \\
(0.100)\end{array}$ & $\begin{array}{c}0.005 \\
(0.101)\end{array}$ & $\begin{array}{l}-0.003 \\
(0.101)\end{array}$ & $\begin{array}{c}0.000 \\
(0.103)\end{array}$ & $\begin{array}{c}0.003 \\
(0.103)\end{array}$ \\
\hline People working in hh & & & $\begin{array}{l}-0.047 \\
(0.030)\end{array}$ & $\begin{array}{l}-0.018 \\
(0.036)\end{array}$ & $\begin{array}{l}-0.018 \\
(0.037)\end{array}$ & $\begin{array}{l}-0.017 \\
(0.037)\end{array}$ & $\begin{array}{l}-0.016 \\
(0.036)\end{array}$ & $\begin{array}{l}-0.016 \\
(0.036)\end{array}$ & $\begin{array}{l}-0.013 \\
(0.036)\end{array}$ & $\begin{array}{l}-0.014 \\
(0.036)\end{array}$ & $\begin{array}{l}-0.016 \\
(0.036)\end{array}$ & $\begin{array}{l}-0.014 \\
(0.036)\end{array}$ \\
\hline Number of hh members & & & & $\begin{array}{c}-0.035^{*} \\
(0.021)\end{array}$ & $\begin{array}{c}-0.036^{*} \\
(0.021)\end{array}$ & $\begin{array}{c}-0.036^{*} \\
(0.021)\end{array}$ & $\begin{array}{c}-0.039^{*} \\
(0.021)\end{array}$ & $\begin{array}{c}-0.040^{*} \\
(0.021)\end{array}$ & $\begin{array}{c}-0.041^{*} \\
(0.021)\end{array}$ & $\begin{array}{l}-0.032 \\
(0.021)\end{array}$ & $\begin{array}{l}-0.033 \\
(0.020)\end{array}$ & $\begin{array}{c}-0.034^{*} \\
(0.020)\end{array}$ \\
\hline Urban & & & & & $\begin{array}{c}-0.131^{* *} \\
(0.058)\end{array}$ & $\begin{array}{c}-0.128^{* *} \\
(0.058)\end{array}$ & $\begin{array}{c}-0.116^{* *} \\
(0.059)\end{array}$ & $\begin{array}{c}-0.118^{* *} \\
(0.060)\end{array}$ & $\begin{array}{c}-0.111^{*} \\
(0.060)\end{array}$ & $\begin{array}{c}-0.099^{*} \\
(0.059)\end{array}$ & $\begin{array}{c}-0.098^{*} \\
(0.059)\end{array}$ & $\begin{array}{c}-0.099^{*} \\
(0.059)\end{array}$ \\
\hline Sex & & & & & & $\begin{array}{l}-0.067 \\
(0.085)\end{array}$ & $\begin{array}{c}-0.064 \\
(0.086)\end{array}$ & $\begin{array}{c}-0.061 \\
(0.086)\end{array}$ & $\begin{array}{l}-0.056 \\
(0.086)\end{array}$ & $\begin{array}{c}-0.075 \\
(0.087)\end{array}$ & $\begin{array}{l}-0.053 \\
(0.086)\end{array}$ & $\begin{array}{c}-0.035 \\
(0.086)\end{array}$ \\
\hline Years of schooling & & & & & & & $\begin{array}{c}-0.011^{*} \\
(0.006)\end{array}$ & $\begin{array}{l}-0.011^{*} \\
(0.006)\end{array}$ & $\begin{array}{l}-0.012^{*} \\
(0.006)\end{array}$ & $\begin{array}{c}-0.022^{* * *} \\
(0.007)\end{array}$ & $\begin{array}{c}-0.021^{* * *} \\
(0.007)\end{array}$ & $\begin{array}{c}-0.019^{* * *} * \\
(0.007)\end{array}$ \\
\hline Age of MFA beneficiaries & & & & & & & & $\begin{array}{l}-0.006 \\
(0.030)\end{array}$ & $\begin{array}{l}-0.011 \\
(0.031)\end{array}$ & $\begin{array}{c}-0.014 \\
(0.031)\end{array}$ & $\begin{array}{c}0.004 \\
(0.030)\end{array}$ & $\begin{array}{c}0.003 \\
(0.031)\end{array}$ \\
\hline Banco Agrario & & & & & & & & & $\begin{array}{c}0.134 \\
(0.112)\end{array}$ & $\begin{array}{c}0.107 \\
(0.111)\end{array}$ & $\begin{array}{c}0.191^{*} \\
(0.111)\end{array}$ & $\begin{array}{c}0.188^{*} \\
(0.109)\end{array}$ \\
\hline Age & & & & & & & & & & $\begin{array}{c}-0.010^{* * *} \\
(0.002)\end{array}$ & $\begin{array}{c}-0.010^{* * *} \\
(0.002)\end{array}$ & $\begin{array}{c}-0.009^{* * *} \\
(0.002)\end{array}$ \\
\hline Account type (deposit) & & & & & & & & & & & $\begin{array}{c}-0.325^{* * *} \\
(0.075)\end{array}$ & $\begin{array}{c}-0.314^{* * *} \\
(0.074)\end{array}$ \\
\hline Mujeres ahorradoras & & & & & & & & & & & & $\begin{array}{c}-0.210^{* *} \\
(0.086)\end{array}$ \\
\hline Observations & 3,126 & 3,126 & 3,126 & 3,125 & 3,117 & 3,117 & 3,117 & 3,105 & 3,105 & 3,105 & 3,105 & 3,105 \\
\hline
\end{tabular}

Note: Coefficients and clustered standard errors (in parentheses) from a probit regression where the dependent variable is an indicator of whether the beneficiary attried or not. ${ }^{* * *} \mathrm{p}<0.01,{ }^{* *} \mathrm{p}<0.05,{ }^{*} \mathrm{p}<0.1$ 
Table 4: Comparison of attrition in the control and treatment groups

\begin{tabular}{|c|c|c|c|}
\hline & $\begin{array}{c}\text { (1) } \\
\text { Attrition } \\
\text { 1st follow-up }\end{array}$ & $\begin{array}{c}(2) \\
\text { Attrition } \\
\text { 2nd follow-up }\end{array}$ & $\begin{array}{c}\text { (3) } \\
\text { Attrition } \\
\text { 3rd follow-up }\end{array}$ \\
\hline Treatment & $\begin{array}{c}0.261 \\
(0.437)\end{array}$ & $\begin{array}{c}0.152 \\
(0.372)\end{array}$ & $\begin{array}{l}-0.139 \\
(0.442)\end{array}$ \\
\hline Treatment $\mathrm{x}$ Children in hh & $\begin{array}{c}0.072 \\
(0.070)\end{array}$ & $\begin{array}{l}-0.070 \\
(0.089)\end{array}$ & $\begin{array}{c}0.018 \\
(0.069)\end{array}$ \\
\hline Treatment $\mathrm{x}$ Someone works in hh & $\begin{array}{c}0.243 \\
(0.191)\end{array}$ & $\begin{array}{l}-0.135 \\
(0.190)\end{array}$ & $\begin{array}{c}0.045 \\
(0.215)\end{array}$ \\
\hline Treatment $x$ People working in hh & $\begin{array}{l}-0.074 \\
(0.054)\end{array}$ & $\begin{array}{c}0.049 \\
(0.075)\end{array}$ & $\begin{array}{l}-0.028 \\
(0.072)\end{array}$ \\
\hline Treatment x Number of hh members & $\begin{array}{c}0.007 \\
(0.037)\end{array}$ & $\begin{array}{l}0.072^{*} \\
(0.043)\end{array}$ & $\begin{array}{l}-0.007 \\
(0.040)\end{array}$ \\
\hline Treatment x Urban & $\begin{array}{l}-0.070 \\
(0.123)\end{array}$ & $\begin{array}{c}0.081 \\
(0.110)\end{array}$ & $\begin{array}{c}-0.246^{* *} \\
(0.124)\end{array}$ \\
\hline Treatment $\mathrm{x}$ Sex & $\begin{array}{c}0.058 \\
(0.163)\end{array}$ & $\begin{array}{c}0.040 \\
(0.166)\end{array}$ & $\begin{array}{c}0.113 \\
(0.181)\end{array}$ \\
\hline Treatment $\mathrm{x}$ Years of schooling & $\begin{array}{c}-0.033^{* *} \\
(0.013)\end{array}$ & $\begin{array}{c}-0.020 * \\
(0.012)\end{array}$ & $\begin{array}{c}0.015 \\
(0.013)\end{array}$ \\
\hline Treatment $\mathrm{x}$ Age of MFA beneficiaries & $\begin{array}{l}-0.018 \\
(0.076)\end{array}$ & $\begin{array}{c}0.032 \\
(0.067)\end{array}$ & $\begin{array}{l}-0.046 \\
(0.062)\end{array}$ \\
\hline Treatment x Banco Agrario & $\begin{array}{c}0.059 \\
(0.217)\end{array}$ & $\begin{array}{c}0.022 \\
(0.110)\end{array}$ & $\begin{array}{l}-0.174 \\
(0.221)\end{array}$ \\
\hline Treatment x Age & $\begin{array}{l}-0.006 \\
(0.006)\end{array}$ & $\begin{array}{l}-0.002 \\
(0.005)\end{array}$ & $\begin{array}{c}0.004 \\
(0.005)\end{array}$ \\
\hline Treatment x Account type & $\begin{array}{l}-0.068 \\
(0.158)\end{array}$ & $\begin{array}{c}-0.289^{*} \\
(0.153)\end{array}$ & $\begin{array}{c}0.111 \\
(0.148)\end{array}$ \\
\hline Treatment x Mujeres Ahorradoras & $\begin{array}{l}-0.081 \\
(0.163)\end{array}$ & $\begin{array}{c}0.213 \\
(0.211)\end{array}$ & $\begin{array}{c}0.080 \\
(0.176)\end{array}$ \\
\hline Observations & 3,105 & 3,105 & 3,105 \\
\hline
\end{tabular}

Note: Coefficients and clustered standard errors (in parenthesis). Regressions include control variables. $* * * \mathrm{p}<0.01,{ }^{* *} \mathrm{p}<0.05, * \mathrm{p}<0.1$ 


\section{Results: Technology Practices}

Table 5: Impact of LISTA on Financial Practices (Technology)

\begin{tabular}{|c|c|c|c|c|c|c|c|c|c|}
\hline & \multicolumn{3}{|c|}{ First follow-up } & \multicolumn{3}{|c|}{ Second follow-up } & \multicolumn{3}{|c|}{ Third follow-up } \\
\hline & Obs & Control & Treatment & Obs & Control & Treatment & Obs & Control & Treatment \\
\hline Has a cellphone & & & & 2,305 & 0.954 & $\begin{array}{c}0.008 \\
(0.006)\end{array}$ & & & \\
\hline Has bought a cellphone after June 2015 & & & & 2,184 & 0.292 & $\begin{array}{l}-0.020 \\
(0.020)\end{array}$ & & & \\
\hline Uses cellphone & & & & 2,305 & 0.993 & $\begin{array}{l}-0.000 \\
(0.003)\end{array}$ & & & \\
\hline Uses WhatsApp on cellphone & & & & 2,289 & 0.292 & $\begin{array}{c}0.037^{* *} \\
(0.018)\end{array}$ & & & \\
\hline Uses Facebook on cellphone & & & & 2,289 & 0.252 & $\begin{array}{c}0.034^{* *} \\
(0.015)\end{array}$ & & & \\
\hline Uses banking app on cellphone & & & & 2,289 & 0.054 & $\begin{array}{l}-0.001 \\
(0.010)\end{array}$ & & & \\
\hline Watches videos on cellphone & & & & 2,289 & 0.423 & $\begin{array}{l}0.035^{*} \\
(0.020)\end{array}$ & & & \\
\hline Has a tablet & & & & 2,301 & 0.098 & $\begin{array}{c}0.004 \\
(0.012)\end{array}$ & & & \\
\hline Has bought a tablet after June 2015 & & & & 2,304 & 0.040 & $\begin{array}{c}-0.006 \\
(0.006)\end{array}$ & & & \\
\hline Uses tablet & & & & 2,280 & 0.258 & $\begin{array}{c}0.396^{* * *} \\
(0.024)\end{array}$ & & & \\
\hline
\end{tabular}

Notes: *** significant at $1 \%,{ }^{* *}$ significant at $5 \%, *$ significant at $10 \%$ (based on $p$-values unadjusted for multiple-hypothesis testing). Clustered standard errors at the municipality level (in parenthesis). Regressions control for randomization blocks, individual and household characteristics (gender, age, number of member in the household,...) and bank characteristics. 


\section{Results: Household monthly expenditure}

Table 6: Impact of LISTA on Expenditure

\begin{tabular}{|c|c|c|c|c|c|c|}
\hline & \multicolumn{3}{|c|}{ Monthly expenditure on item } & \multicolumn{3}{|c|}{ Expenditure on item / Total } \\
\hline & Obs & Control & Treatment & Obs & Control & Treatment \\
\hline Total monthly expenditure & 2,305 & 779,122 & $\begin{array}{c}-0.002 \\
(0.058)\end{array}$ & & & \\
\hline Utilities (water, gas, electricity) & 2,296 & $48,437.442$ & $\begin{array}{c}0.153^{* * *} \\
(0.055)\end{array}$ & 2,295 & 0.072 & $\begin{array}{l}0.010^{* *} \\
(0.005)\end{array}$ \\
\hline Telephone, internet & 2,297 & 12,610 & $\begin{array}{c}-0.043 \\
(0.056)\end{array}$ & 2,296 & 0.017 & $\begin{array}{c}-0.002 \\
(0.002)\end{array}$ \\
\hline Celphone services & 2,247 & 15,229 & $\begin{array}{c}-0.014 \\
(0.055)\end{array}$ & 2,246 & 0.020 & $\begin{array}{c}0.000 \\
(0.001)\end{array}$ \\
\hline Clothes & 2,294 & 19,761 & $\begin{array}{c}-0.025 \\
(0.050)\end{array}$ & 2,293 & 0.022 & $\begin{array}{c}-0.002 \\
(0.003)\end{array}$ \\
\hline Rent & 2,303 & 19,015 & $\begin{array}{c}0.028 \\
(0.039)\end{array}$ & 2,302 & 0.023 & $\begin{array}{c}-0.001 \\
(0.003)\end{array}$ \\
\hline Gas & 2,305 & 3,509 & $\begin{array}{c}-0.150^{* *} \\
(0.066)\end{array}$ & 2,304 & 0.004 & $\begin{array}{c}-0.003^{* *} \\
(0.002)\end{array}$ \\
\hline Repaying debt & 2,305 & 18,382 & $\begin{array}{c}-0.042 \\
(0.061)\end{array}$ & 2,304 & 0.015 & $\begin{array}{c}-0.001 \\
(0.004)\end{array}$ \\
\hline Water & 2,305 & 1,167 & $\begin{array}{c}-0.102 \\
(0.074)\end{array}$ & 2,304 & 0.001 & $\begin{array}{c}-0.001 \\
(0.001)\end{array}$ \\
\hline Home appliances & 2,305 & 1,232 & $\begin{array}{c}-0.034 \\
(0.044)\end{array}$ & 2,304 & 0.001 & $\begin{array}{c}-0.000 \\
(0.001)\end{array}$ \\
\hline Fixing the house & 2,305 & 1,888 & $\begin{array}{c}-0.041 \\
(0.040)\end{array}$ & 2,304 & 0.001 & $\begin{array}{c}-0.001 \\
(0.001)\end{array}$ \\
\hline Fixing the vehicle & 2,305 & $2,304.952$ & $\begin{array}{c}-0.063 \\
(0.053)\end{array}$ & 2,304 & 0.001 & $\begin{array}{c}-0.001 \\
(0.001)\end{array}$ \\
\hline Emergencies & 2,305 & 260.643 & $\begin{array}{c}0.031 \\
(0.034)\end{array}$ & 2,304 & 0.000 & $\begin{array}{c}0.000 \\
(0.000)\end{array}$ \\
\hline
\end{tabular}

Notes: ${ }^{* *}$ significant at $1 \%,{ }^{* *}$ significant at $5 \%, *$ significant at $10 \%$ (based on $p$-values unadjusted for multiple-hypothesis testing). Clustered standard errors at the municipality level (in parenthesis). Regressions control for randomization blocks, individual and household characteristics (gender, age, number of member in the household,...) and bank characteristics. Results only available for the second
follow-up. 
Table 7: Impact of LISTA on Expenditure

\begin{tabular}{|c|c|c|c|c|c|c|}
\hline & \multicolumn{3}{|c|}{ Monthly expenditure on item } & \multicolumn{3}{|c|}{ Expenditure on item / Total } \\
\hline & Obs & Control & Treatment & Obs & Control & Treatment \\
\hline Food & 2,256 & 421,477 & $\begin{array}{c}0.016 \\
(0.045)\end{array}$ & 2,256 & 0.546 & $\begin{array}{c}-0.003 \\
(0.011)\end{array}$ \\
\hline Cleaning & 2,247 & 82,218 & $\begin{array}{c}-0.039 \\
(0.049)\end{array}$ & 2,256 & 0.546 & $\begin{array}{c}-0.003 \\
(0.011)\end{array}$ \\
\hline Transport & 2,279 & 69,800 & $\begin{array}{c}0.059 \\
(0.053)\end{array}$ & 2,256 & 0.546 & $\begin{array}{c}-0.003 \\
(0.011)\end{array}$ \\
\hline Tabaco, alcohol, and others & 2,291 & 4,600 & $\begin{array}{c}-0.005 \\
(0.048)\end{array}$ & 2,256 & 0.546 & $\begin{array}{c}-0.003 \\
(0.011)\end{array}$ \\
\hline Leisure & 2,300 & 5,261 & $\begin{array}{c}0.067 \\
(0.057)\end{array}$ & 2,299 & 0.006 & $\begin{array}{c}0.001 \\
(0.002)\end{array}$ \\
\hline Health & 2,266 & 15,302 & $\begin{array}{c}-0.015 \\
(0.034)\end{array}$ & 2,265 & 0.019 & $\begin{array}{c}0.001 \\
(0.002)\end{array}$ \\
\hline Education & 2,246 & 44,032 & $\begin{array}{c}-0.031 \\
(0.053)\end{array}$ & 2,245 & 0.064 & $\begin{array}{c}-0.002 \\
(0.003)\end{array}$ \\
\hline Business & 2,305 & 882 & $\begin{array}{c}-0.043 \\
(0.040)\end{array}$ & 2,304 & 0.001 & $\begin{array}{c}-0.000 \\
(0.000)\end{array}$ \\
\hline Birthdays & 2,305 & 226 & $\begin{array}{c}0.041 \\
(0.040)\end{array}$ & 2,304 & 0.000 & $\begin{array}{c}0.001 \\
(0.001)\end{array}$ \\
\hline
\end{tabular}

Notes: *** significant at $1 \%, * *$ significant at $5 \%, *$ significant at $10 \%$ (based on $p$-values unadjusted for multiple-hypothesis testing). Clustered standard errors at the municipality level (in parenthesis). Regressions control for randomization blocks, individual and household characteristics (gender, age, number of member in the household,...) and bank characteristics. Results only available for the second follow-up. 


\section{Results: Financial performance}

Table 8: Impact of LISTA on Financial Performance - Administrative Data

\begin{tabular}{|c|c|c|c|c|c|c|c|c|}
\hline & May & Jun & Jul & Aug & Sep & Oct & Nov & Dec \\
\hline \multicolumn{9}{|l|}{ Panel A: Non-standardized effects } \\
\hline Number of monthly withdraws (a) & $\begin{array}{c}0.004 \\
(0.023)\end{array}$ & $\begin{array}{c}0.009 \\
(0.006)\end{array}$ & $\begin{array}{l}-0.042 \\
(0.050)\end{array}$ & $\begin{array}{l}-0.041 \\
(0.032)\end{array}$ & $\begin{array}{c}0.035 \\
(0.046)\end{array}$ & $\begin{array}{c}0.007 \\
(0.007)\end{array}$ & $\begin{array}{l}-0.025 \\
(0.050)\end{array}$ & $\begin{array}{l}-0.050 \\
(0.052)\end{array}$ \\
\hline Number of other debit transactions (b) & $\begin{array}{l}-0.022 \\
(0.017)\end{array}$ & $\begin{array}{l}-0.002 \\
(0.010)\end{array}$ & $\begin{array}{l}-0.017 \\
(0.020)\end{array}$ & $\begin{array}{l}-0.001 \\
(0.006)\end{array}$ & $\begin{array}{c}0.025 \\
(0.030)\end{array}$ & $\begin{array}{r}0.009^{* *} \\
(0.004)\end{array}$ & $\begin{array}{c}0.007 \\
(0.016)\end{array}$ & $\begin{array}{r}0.015^{* *} \\
(0.007)\end{array}$ \\
\hline Number of total debit transactions $(a)+(b)$ & $\begin{array}{l}-0.013 \\
(0.030)\end{array}$ & $\begin{array}{c}0.008 \\
(0.010)\end{array}$ & $\begin{array}{l}-0.057 \\
(0.056)\end{array}$ & $\begin{array}{l}-0.041 \\
(0.032)\end{array}$ & $\begin{array}{c}0.057 \\
(0.052)\end{array}$ & $\begin{array}{c}0.015 \\
(0.010)\end{array}$ & $\begin{array}{l}-0.014 \\
(0.049)\end{array}$ & $\begin{array}{l}-0.035 \\
(0.052)\end{array}$ \\
\hline Number of active credits (c) & $\begin{array}{c}0.005^{* *} \\
(0.002)\end{array}$ & $\begin{array}{c}0.002 \\
(0.002)\end{array}$ & $\begin{array}{l}-0.001 \\
(0.002)\end{array}$ & $\begin{array}{c}0.002 \\
(0.002)\end{array}$ & $\begin{array}{c}0.005 \\
(0.004)\end{array}$ & $\begin{array}{l}-0.000 \\
(0.003)\end{array}$ & $\begin{array}{c}0.001 \\
(0.002)\end{array}$ & $\begin{array}{l}-0.000 \\
(0.002)\end{array}$ \\
\hline Number of monthly deposits (d) & $\begin{array}{c}0.003 \\
(0.007)\end{array}$ & $\begin{array}{c}0.009^{* * *} \\
(0.003)\end{array}$ & $\begin{array}{l}0.055^{*} \\
(0.030)\end{array}$ & $\begin{array}{c}0.013 \\
(0.011)\end{array}$ & $\begin{array}{c}0.030 \\
(0.019)\end{array}$ & $\begin{array}{l}-0.000 \\
(0.003)\end{array}$ & $\begin{array}{c}0.081^{* *} \\
(0.034)\end{array}$ & $\begin{array}{c}0.011 \\
(0.022)\end{array}$ \\
\hline Total transactionality $(\mathrm{a})+(\mathrm{b})+(\mathrm{c})+(\mathrm{d})$ & $\begin{array}{l}-0.010 \\
(0.033)\end{array}$ & $\begin{array}{l}0.019^{*} \\
(0.011)\end{array}$ & $\begin{array}{l}-0.007 \\
(0.072)\end{array}$ & $\begin{array}{l}-0.008 \\
(0.038)\end{array}$ & $\begin{array}{c}0.094 \\
(0.058)\end{array}$ & $\begin{array}{c}0.016 \\
(0.011)\end{array}$ & $\begin{array}{c}0.063 \\
(0.071)\end{array}$ & $\begin{array}{l}-0.012 \\
(0.069)\end{array}$ \\
\hline Average monthly account balance & $\begin{array}{l}3,616.752^{*} \\
(2,100.507)\end{array}$ & $\begin{array}{c}2,041.990 \\
(1,637.884)\end{array}$ & $\begin{array}{c}6,531.610^{* * *} \\
(1,876.770)\end{array}$ & $\begin{array}{r}3,819.453^{* *} \\
(1,533.978)\end{array}$ & $\begin{array}{l}4,425.518^{*} \\
(2,597.346)\end{array}$ & $\begin{array}{c}2,672.709 \\
(1,619.132)\end{array}$ & $\begin{array}{l}4,096.390^{*} \\
(2,403.549)\end{array}$ & $\begin{array}{r}5,569.400^{* *} \\
(2,276.862)\end{array}$ \\
\hline Maximum monthly account balance & $\begin{array}{l}7,853.093^{* *} \\
(3,337.649)\end{array}$ & $\begin{array}{l}4,241.635^{*} \\
(2,288.351)\end{array}$ & $\begin{array}{c}5,385.363 \\
(5,011.287)\end{array}$ & $\begin{array}{c}1,841.118 \\
(2,866.701)\end{array}$ & $\begin{array}{c}17,735.971^{* * *} \\
(5,482.454)\end{array}$ & $\begin{array}{c}3,083.098 \\
(1,988.390)\end{array}$ & $\begin{array}{c}4,201.990 \\
(4,686.818)\end{array}$ & $\begin{array}{c}7,420.492 \\
(6,229.629)\end{array}$ \\
\hline Number of monthly withdraws (a) & $\begin{array}{c}0.005 \\
(0.031)\end{array}$ & $\begin{array}{c}0.012 \\
(0.008)\end{array}$ & $\begin{array}{l}-0.055 \\
(0.066)\end{array}$ & $\begin{array}{l}-0.053 \\
(0.042)\end{array}$ & $\begin{array}{c}0.045 \\
(0.060)\end{array}$ & $\begin{array}{c}0.009 \\
(0.010)\end{array}$ & $\begin{array}{l}-0.033 \\
(0.066)\end{array}$ & $\begin{array}{l}-0.066 \\
(0.068)\end{array}$ \\
\hline Number of other debit transactions (b) & $\begin{array}{l}-0.053 \\
(0.042)\end{array}$ & $\begin{array}{l}-0.006 \\
(0.023)\end{array}$ & $\begin{array}{l}-0.041 \\
(0.049)\end{array}$ & $\begin{array}{l}-0.002 \\
(0.016)\end{array}$ & $\begin{array}{c}0.060 \\
(0.072)\end{array}$ & $\begin{array}{c}0.022^{* *} \\
(0.010)\end{array}$ & $\begin{array}{c}0.017 \\
(0.039)\end{array}$ & $\begin{array}{c}0.037^{* *} \\
(0.017)\end{array}$ \\
\hline Number of total debit transactions $(a)+(b)$ & $\begin{array}{l}-0.016 \\
(0.036)\end{array}$ & $\begin{array}{c}0.010 \\
(0.012)\end{array}$ & $\begin{array}{l}-0.068 \\
(0.067)\end{array}$ & $\begin{array}{l}-0.049 \\
(0.038)\end{array}$ & $\begin{array}{c}0.068 \\
(0.062)\end{array}$ & $\begin{array}{c}0.019 \\
(0.012)\end{array}$ & $\begin{array}{l}-0.016 \\
(0.058)\end{array}$ & $\begin{array}{l}-0.042 \\
(0.062)\end{array}$ \\
\hline Number of active credits (c) & $\begin{array}{c}0.093^{* *} \\
(0.042)\end{array}$ & $\begin{array}{c}0.047 \\
(0.040)\end{array}$ & $\begin{array}{l}-0.014 \\
(0.046)\end{array}$ & $\begin{array}{c}0.038 \\
(0.042)\end{array}$ & $\begin{array}{c}0.100 \\
(0.073)\end{array}$ & $\begin{array}{l}-0.008 \\
(0.052)\end{array}$ & $\begin{array}{c}0.017 \\
(0.032)\end{array}$ & $\begin{array}{l}-0.003 \\
(0.041)\end{array}$ \\
\hline Number of monthly deposits (d) & $\begin{array}{c}0.006 \\
(0.014)\end{array}$ & $\begin{array}{c}0.016^{* * *} \\
(0.005)\end{array}$ & $\begin{array}{l}0.102^{*} \\
(0.055)\end{array}$ & $\begin{array}{c}0.023 \\
(0.021)\end{array}$ & $\begin{array}{c}0.055 \\
(0.035)\end{array}$ & $\begin{array}{l}-0.000 \\
(0.005)\end{array}$ & $\begin{array}{c}0.150^{* *} \\
(0.063)\end{array}$ & $\begin{array}{c}0.021 \\
(0.041)\end{array}$ \\
\hline Total transactionality $(\mathrm{a})+(\mathrm{b})+(\mathrm{c})+(\mathrm{d})$ & $\begin{array}{l}-0.008 \\
(0.027)\end{array}$ & $\begin{array}{l}0.016^{*} \\
(0.009)\end{array}$ & $\begin{array}{l}-0.006 \\
(0.060)\end{array}$ & $\begin{array}{l}-0.007 \\
(0.032)\end{array}$ & $\begin{array}{c}0.078 \\
(0.048)\end{array}$ & $\begin{array}{c}0.013 \\
(0.009)\end{array}$ & $\begin{array}{c}0.053 \\
(0.060)\end{array}$ & $\begin{array}{l}-0.010 \\
(0.058)\end{array}$ \\
\hline Average monthly account balance & $\begin{array}{l}0.047^{*} \\
(0.027)\end{array}$ & $\begin{array}{c}0.026 \\
(0.021)\end{array}$ & $\begin{array}{c}0.084^{* * *} \\
(0.024)\end{array}$ & $\begin{array}{c}0.049^{* *} \\
(0.020)\end{array}$ & $\begin{array}{l}0.057^{*} \\
(0.034)\end{array}$ & $\begin{array}{c}0.035 \\
(0.021)\end{array}$ & $\begin{array}{l}0.053^{*} \\
(0.031)\end{array}$ & $\begin{array}{c}0.072^{* *} \\
(0.029)\end{array}$ \\
\hline Maximum monthly account balance & $\begin{array}{c}0.057^{* *} \\
(0.024)\end{array}$ & $\begin{array}{l}0.031^{*} \\
(0.017)\end{array}$ & $\begin{array}{c}0.039 \\
(0.036)\end{array}$ & $\begin{array}{c}0.013 \\
(0.021)\end{array}$ & $\begin{array}{c}0.128^{* * *} \\
(0.040)\end{array}$ & $\begin{array}{c}0.022 \\
(0.014)\end{array}$ & $\begin{array}{c}0.030 \\
(0.034)\end{array}$ & $\begin{array}{c}0.054 \\
(0.045)\end{array}$ \\
\hline
\end{tabular}

Notes: Average savings are standardized using the mean and the variance from January 2014. Controls include: randomization blocks, account is from Banco Agrario, average savings up to April 2015, number of financial institutions in the district, and a set of socioeconomic covariates at the municipal level. Clustered standard errors in parenthesis. ${ }^{*} \mathrm{pi} .1,{ }^{* *} \mathrm{p}$ i.05, ${ }^{* * *} \mathrm{pi} .01$. 


\section{Results: Estimates without Controls}

Table 9: Impact of LISTA on Financial Knowledge - without Controls

\begin{tabular}{|c|c|c|c|c|c|c|c|c|c|}
\hline & \multicolumn{3}{|c|}{ First follow-up } & \multicolumn{3}{|c|}{ Second follow-up } & \multicolumn{3}{|c|}{ Third follow-up } \\
\hline & Obs & Control & Treatment & Obs & Control & Treatment & Obs & Control & Treatment \\
\hline Knowledge: total score & 2,502 & 5.120 & $\begin{array}{c}0.199^{* * *} \\
(0.036)\end{array}$ & 2,305 & 5.574 & $\begin{array}{c}0.173^{* * *} \\
(0.055)\end{array}$ & 2,180 & 5.325 & $\begin{array}{c}0.124^{* * *} \\
(0.045)\end{array}$ \\
\hline Knowledge: savings section & 2,502 & 2.110 & $\begin{array}{c}0.227^{* * *} \\
(0.036) \\
{[0.000]}\end{array}$ & 2,305 & 2.256 & $\begin{array}{c}0.154^{* * *} \\
(0.054) \\
{[0.012]}\end{array}$ & 2,180 & 2.059 & $\begin{array}{l}0.114^{* *} \\
(0.050) \\
{[0.046]}\end{array}$ \\
\hline Knowledge: budget section & 2,502 & 1.442 & $\begin{array}{c}0.141^{* * *} \\
(0.040) \\
{[0.001]}\end{array}$ & 2,305 & 1.602 & $\begin{array}{c}0.074 \\
(0.047) \\
{[0.126]}\end{array}$ & 2,180 & 1.540 & $\begin{array}{c}0.124^{* * *} \\
(0.037) \\
{[0.000]}\end{array}$ \\
\hline Knowledge: debt section & 2,502 & 1.568 & $\begin{array}{c}-0.015 \\
(0.044) \\
{[0.728]}\end{array}$ & 2,305 & 1.716 & $\begin{array}{c}0.076^{*} \\
(0.042) \\
{[0.126]}\end{array}$ & 2,180 & 1.726 & $\begin{array}{c}-0.025 \\
(0.045) \\
{[0.567]}\end{array}$ \\
\hline Knowledge extended: total score & & & & 2,305 & 8.639 & $\begin{array}{c}0.190^{* * *} \\
(0.064)\end{array}$ & 2,180 & 7.790 & $\begin{array}{c}0.156^{* * *} \\
(0.052)\end{array}$ \\
\hline Knowledge extended: savings & & & & 2,305 & 3.135 & $\begin{array}{c}0.164^{* * *} \\
(0.057) \\
{[0.015]}\end{array}$ & 2,180 & 2.908 & $\begin{array}{l}0.124^{* *} \\
(0.051) \\
{[0.023]}\end{array}$ \\
\hline Knowledge extended: budget & & & & 2,305 & 2.262 & $\begin{array}{l}0.151^{* *} \\
(0.058) \\
{[0.025]}\end{array}$ & 2,180 & 1.971 & $\begin{array}{c}0.158^{* * *} \\
(0.049) \\
{[0.001]}\end{array}$ \\
\hline Knowledge extended: debt & & & & 2,305 & 3.242 & $\begin{array}{c}0.064 \\
(0.050) \\
{[0.185]}\end{array}$ & 2,180 & 2.911 & $\begin{array}{c}0.021 \\
(0.040) \\
{[0.582]}\end{array}$ \\
\hline Knowledge extended: math & & & & 2,305 & 1.623 & $\begin{array}{c}0.090^{*} \\
(0.053) \\
{[0.157]}\end{array}$ & & & \\
\hline
\end{tabular}

Notes: *** significant at $1 \%, * *$ significant at $5 \%, *$ significant at $10 \%$, based on $p$-values unadjusted for multiple-hypothesis testing. Clustered standard errors at the municipality level (in parenthesis) Romano-Wolf adjusted $p$-values (in square brackets). Regressions control only for randomization blocks. The control means column shows non-standardized values. 
Table 10: Impact of LISTA on Financial Attitudes - without Controls

\begin{tabular}{|c|c|c|c|c|c|c|c|c|c|}
\hline & \multicolumn{3}{|c|}{ First follow-up } & \multicolumn{3}{|c|}{ Second follow-up } & \multicolumn{3}{|c|}{ Third follow-up } \\
\hline & Obs & Control & Treatment & Obs & Control & Treatment & Obs & Control & Treatment \\
\hline Has a savings goal & 2,396 & 0.368 & $\begin{array}{c}0.168^{* * *} \\
(0.023) \\
{[0.000]}\end{array}$ & 2,301 & 0.270 & $\begin{array}{c}0.074^{* * * *} \\
(0.024) \\
{[0.004]}\end{array}$ & 2,177 & 0.280 & $\begin{array}{c}0.118^{* * *} \\
(0.023) \\
{[0.000]}\end{array}$ \\
\hline Believes can leave money in MFA account & 1,597 & 0.650 & $\begin{array}{c}0.125^{* * *} \\
(0.021) \\
{[0.000]}\end{array}$ & 1,405 & 0.685 & $\begin{array}{c}0.072^{* * *} \\
(0.024) \\
{[0.005]}\end{array}$ & 1,441 & 0.736 & $\begin{array}{c}0.053^{*} \\
(0.029) \\
{[0.267]}\end{array}$ \\
\hline Trust in bank & 1,749 & 2.727 & $\begin{array}{c}0.201^{* * *} \\
(0.045) \\
{[0.000]}\end{array}$ & 1,588 & 2.616 & $\begin{array}{c}0.205^{* * *} \\
(0.050) \\
{[0.000]}\end{array}$ & 1,528 & 2.604 & $\begin{array}{c}0.083^{*} \\
(0.049) \\
{[0.267]}\end{array}$ \\
\hline Comfort with banks & 1,720 & 2.356 & $\begin{array}{c}0.187^{* * *} * \\
(0.047) \\
{[0.000]}\end{array}$ & 1,557 & 2.471 & $\begin{array}{c}0.026 \\
(0.057) \\
{[0.653]}\end{array}$ & 1,510 & 2.599 & $\begin{array}{c}0.088 \\
(0.053) \\
{[0.267]}\end{array}$ \\
\hline Preference: money in bank vs. cash & 1,773 & 3.552 & $\begin{array}{c}0.145^{* * *} \\
(0.037) \\
{[0.000]}\end{array}$ & 1,624 & 2.734 & $\begin{array}{c}0.176^{* * *} \\
(0.050) \\
{[0.004]}\end{array}$ & 1,555 & 2.796 & $\begin{array}{c}0.186^{* * *} \\
(0.056) \\
{[0.003]}\end{array}$ \\
\hline Intertemporal preference: today vs. one month & & & & 1,621 & 3.170 & $\begin{array}{c}-0.175^{* * *} \\
(0.047) \\
{[0.001]}\end{array}$ & 1,553 & 2.971 & $\begin{array}{c}-0.089^{*} \\
(0.052) \\
{[0.267]}\end{array}$ \\
\hline
\end{tabular}

Notes: $* * *$ significant at $1 \%, * *$ significant at $5 \%, *$ significant at $10 \%$, based on $p$-values unadjusted for multiple-hypothesis testing. Clustered standard errors at the municipality level (in parenthesis). Romano-Wolf adjusted $p$-values (in square brackets). Regressions control only for randomization blocks. The control means column shows non-standardized values. 
Table 11: Impact of LISTA on Financial Practices (ATM, MFA) - without Controls

\begin{tabular}{|c|c|c|c|c|c|c|c|c|c|}
\hline & \multicolumn{3}{|c|}{ First follow-up } & \multicolumn{3}{|c|}{ Second follow-up } & \multicolumn{3}{|c|}{ Third follow-up } \\
\hline & Obs & Control & Treatment & Obs & Control & Treatment & Obs & Control & Treatment \\
\hline Manages household finances & 1,712 & 0.929 & $\begin{array}{c}0.015^{*} \\
(0.009) \\
{[0.236]}\end{array}$ & 1,582 & 0.915 & $\begin{array}{c}0.016 \\
(0.011) \\
{[0.585]}\end{array}$ & 1,512 & 0.932 & $\begin{array}{c}0.006 \\
(0.012) \\
{[0.977]}\end{array}$ \\
\hline Keeps written track of accounts & 1,655 & 0.228 & $\begin{array}{c}0.036 \\
(0.022) \\
{[0.236]}\end{array}$ & 1,500 & 0.158 & $\begin{array}{c}0.009 \\
(0.017) \\
{[0.943]}\end{array}$ & 1,451 & 0.347 & $\begin{array}{c}0.011 \\
(0.026) \\
{[0.977]}\end{array}$ \\
\hline Withdrew last MFA transfer & 1,663 & 0.840 & $\begin{array}{l}-0.012 \\
(0.013) \\
{[0.369]}\end{array}$ & 1,577 & 0.782 & $\begin{array}{c}0.005 \\
(0.016) \\
{[0.943]}\end{array}$ & 1,448 & 0.835 & $\begin{array}{c}0.032 \\
(0.020) \\
{[0.555]}\end{array}$ \\
\hline Accompanied when withdrew & 1,521 & 0.401 & $\begin{array}{c}0.061^{* * *} \\
(0.021) \\
{[0.014]}\end{array}$ & 982 & 0.492 & $\begin{array}{c}0.039 \\
(0.028) \\
{[0.585]}\end{array}$ & 1,415 & 0.412 & $\begin{array}{c}0.033 \\
(0.031) \\
{[0.873]}\end{array}$ \\
\hline Has money in MFA account (today) & & & & 1,237 & 0.353 & $\begin{array}{c}0.063^{*} \\
(0.034) \\
{[0.384]}\end{array}$ & 1,318 & 0.497 & $\begin{array}{c}0.049 \\
(0.035) \\
{[0.712]}\end{array}$ \\
\hline Leaves money in MFA account & & & & 1,384 & 0.360 & $\begin{array}{c}0.065^{* *} \\
(0.026) \\
{[0.107]}\end{array}$ & 1,411 & 0.419 & $\begin{array}{c}0.019 \\
(0.033) \\
{[0.977]}\end{array}$ \\
\hline Someone helped use ATM & & & & 494 & 0.661 & $\begin{array}{c}0.008 \\
(0.044) \\
{[0.943]}\end{array}$ & 600 & 0.630 & $\begin{array}{c}0.022 \\
(0.037) \\
{[0.977]}\end{array}$ \\
\hline Feels can teach ATM use & & & & 1,563 & 0.390 & $\begin{array}{c}0.063^{* *} \\
(0.028) \\
{[0.186]}\end{array}$ & 1,508 & 0.555 & $\begin{array}{l}-0.013 \\
(0.023) \\
{[0.977]}\end{array}$ \\
\hline Has taught someone use ATM & & & & 1,563 & 0.195 & $\begin{array}{c}0.051^{*} \\
(0.028) \\
{[0.384]}\end{array}$ & 1,508 & 0.255 & $\begin{array}{c}0.023 \\
(0.027) \\
{[0.933]}\end{array}$ \\
\hline Has a MFA card & & & & 1,577 & 0.822 & $\begin{array}{c}0.036 \\
(0.047) \\
{[0.886]}\end{array}$ & 1,449 & 0.956 & $\begin{array}{c}0.029^{*} \\
(0.016) \\
{[0.447]}\end{array}$ \\
\hline
\end{tabular}

Notes: $* * *$ significant at $1 \%, * *$ significant at $5 \%, *$ significant at $10 \%$, based on $p$-values unadjusted for multiple-hypothesis testing. Clustered standard errors at the municipality level (in parenthesis). Romano-Wolf adjusted $p$-values (in square brackets). Regressions control only for randomization blocks. The control means column shows non-standardized values. 
Table 12: Impact of LISTA on Financial Practices (Budget) - without Controls

\begin{tabular}{|c|c|c|c|c|c|c|c|c|c|}
\hline & \multicolumn{3}{|c|}{ First follow-up } & \multicolumn{3}{|c|}{ Second follow-up } & \multicolumn{3}{|c|}{ Third follow-up } \\
\hline & Obs & Control & Treatment & Obs & Control & Treatment & Obs & Control & Treatment \\
\hline \multicolumn{10}{|l|}{ In case of a $350 \mathrm{k}$ emergency } \\
\hline Would use loans & 2,412 & 0.752 & $\begin{array}{c}-0.156^{* * *} \\
(0.023) \\
{[0.000]}\end{array}$ & 2,223 & 0.822 & $\begin{array}{c}-0.106^{* * *} \\
(0.017) \\
{[0.000]}\end{array}$ & 2,121 & 0.838 & $\begin{array}{c}-0.063^{* * *} \\
(0.022) \\
{[0.019]}\end{array}$ \\
\hline Would sell or pawn something & 2,412 & 0.036 & $\begin{array}{c}-0.009 \\
(0.008) \\
{[0.250]}\end{array}$ & 2,223 & 0.099 & $\begin{array}{c}0.022 \\
(0.015) \\
{[0.146]}\end{array}$ & 2,121 & 0.042 & $\begin{array}{c}0.006 \\
(0.011) \\
{[0.807]}\end{array}$ \\
\hline Would look for a job & & & & 2,247 & 0.029 & $\begin{array}{c}-0.014 * * \\
(0.006) \\
{[0.044]}\end{array}$ & 2,141 & 0.026 & $\begin{array}{c}-0.001 \\
(0.007) \\
{[0.844]}\end{array}$ \\
\hline Would spend on healthcare or education & & & & 2,305 & 0.083 & $\begin{array}{c}0.009 \\
(0.012) \\
{[0.689]}\end{array}$ & 2,172 & 0.962 & $\begin{array}{c}0.005 \\
(0.009) \\
{[0.772]}\end{array}$ \\
\hline Would build, improve or buy a house & & & & 2,294 & 0.796 & $\begin{array}{c}-0.018 \\
(0.020) \\
{[0.689]}\end{array}$ & 2,172 & 0.802 & $\begin{array}{c}0.020 \\
(0.019) \\
{[0.635]}\end{array}$ \\
\hline Would spend on household expenses & & & & 2,305 & 0.063 & $\begin{array}{c}-0.018^{*} \\
(0.010) \\
{[0.308]}\end{array}$ & 2,175 & 0.833 & $\begin{array}{c}-0.010 \\
(0.017) \\
{[0.772]}\end{array}$ \\
\hline Would invest in business & & & & 2,300 & 0.843 & $\begin{array}{c}0.015 \\
(0.015) \\
{[0.689]}\end{array}$ & 2,176 & 0.895 & $\begin{array}{c}0.022 \\
(0.014) \\
{[0.380]}\end{array}$ \\
\hline Was able to cover household expenses & & & & 2,112 & 0.361 & $\begin{array}{c}0.037^{*} \\
(0.020) \\
{[0.130]}\end{array}$ & 2,004 & 0.366 & $\begin{array}{c}0.078^{* * *} \\
(0.021) \\
{[0.001]}\end{array}$ \\
\hline
\end{tabular}

Notes: *** significant at $1 \%, * *$ significant at $5 \%, *$ significant at $10 \%$, based on $p$-values unadjusted for multiple-hypothesis testing. Clustered standard errors at the municipality level (in parenthesis). Romano-Wolf adjusted $p$-values (in square brackets). Regressions control only for randomization blocks. The control means column shows non-standardized values. 
Table 13: Impact of LISTA on Financial Performance (Self - Reported) - without Controls

\begin{tabular}{|c|c|c|c|c|c|c|c|c|c|}
\hline & \multicolumn{3}{|c|}{ First follow-up } & \multicolumn{3}{|c|}{ Second follow-up } & \multicolumn{3}{|c|}{ Third follow-up } \\
\hline & Obs & Control & Treatment & Obs & Control & Treatment & Obs & Control & Treatment \\
\hline \multicolumn{10}{|l|}{ Panel A: Probability of saving } \\
\hline Has formal or informal savings & 2,502 & 0.601 & $\begin{array}{c}0.147^{* * *} \\
(0.022)\end{array}$ & 2,305 & 0.385 & $\begin{array}{c}0.112^{* * * *} \\
(0.019)\end{array}$ & 2,180 & 0.434 & $\begin{array}{c}0.110^{* * *} \\
(0.024)\end{array}$ \\
\hline Has formal savings & 2,502 & 0.105 & $\begin{array}{l}0.030^{* *} \\
(0.013)\end{array}$ & 2,305 & 0.092 & $\begin{array}{c}0.008 \\
(0.011)\end{array}$ & 2,178 & 0.101 & $\begin{array}{c}0.023 \\
(0.014)\end{array}$ \\
\hline Has informal savings & 2,501 & 0.568 & $\begin{array}{c}0.150^{* * *} \\
(0.022)\end{array}$ & 2,304 & 0.334 & $\begin{array}{c}0.109^{* * *} \\
(0.020)\end{array}$ & 2,180 & 0.390 & $\begin{array}{c}0.099^{* * *} \\
(0.022)\end{array}$ \\
\hline Has savings in a bank & 2,488 & 0.052 & $\begin{array}{c}0.029^{* * *} \\
(0.009) \\
{[0.005]}\end{array}$ & 2,299 & 0.063 & $\begin{array}{c}-0.003 \\
(0.009) \\
{[0.796]}\end{array}$ & 2,170 & 0.063 & $\begin{array}{c}0.008 \\
(0.012) \\
{[0.457]}\end{array}$ \\
\hline Has savings in cooperative & 2,481 & 0.059 & $\begin{array}{c}0.016 \\
(0.012) \\
{[0.133]}\end{array}$ & 2,297 & 0.032 & $\begin{array}{c}0.016^{*} \\
(0.008) \\
{[0.107]}\end{array}$ & 2,172 & 0.045 & $\begin{array}{c}0.020^{* *} \\
(0.008) \\
{[0.016]}\end{array}$ \\
\hline Has savings in piggy bank & 2,492 & 0.559 & $\begin{array}{c}0.149^{* * *} \\
(0.022) \\
{[0.000]}\end{array}$ & 2,298 & 0.325 & $\begin{array}{c}0.106^{* * *} \\
(0.020) \\
{[0.000]}\end{array}$ & 2,173 & 0.360 & $\begin{array}{c}0.092^{* * *} \\
(0.018) \\
{[0.000]}\end{array}$ \\
\hline \multicolumn{10}{|l|}{ Panel B: Tobit estimates for savings } \\
\hline Total formal and informal savings & 2,519 & 115,635 & $\begin{array}{c}0.505^{* * *} \\
(0.160)\end{array}$ & 2,322 & 138,010 & $\begin{array}{c}0.889^{* * *} \\
(0.338)\end{array}$ & 2,195 & 156,347 & $\begin{array}{c}0.851^{* * *} \\
(0.304)\end{array}$ \\
\hline Total formal savings & 2,519 & 38,248 & $\begin{array}{l}1.326^{* *} \\
(0.659)\end{array}$ & 2,322 & 63,128 & $\begin{array}{c}1.303 \\
(1.199)\end{array}$ & 2,194 & 57,070 & $\begin{array}{c}1.311 \\
(1.036)\end{array}$ \\
\hline Total informal savings & 2,519 & 70,934 & $\begin{array}{c}0.507^{* * *} \\
(0.159)\end{array}$ & 2,322 & 53,033 & $\begin{array}{c}0.840^{* * *} \\
(0.277)\end{array}$ & 2,135 & 88,950 & $\begin{array}{c}0.997^{* * *} \\
(0.267)\end{array}$ \\
\hline Savings in a bank & 2,519 & 17,161 & $\begin{array}{c}3.294^{* * *} \\
(1.101) \\
{[0.007]}\end{array}$ & 2,322 & 39,249 & $\begin{array}{c}0.730 \\
(2.170) \\
{[0.767]}\end{array}$ & 2,186 & 26,124 & $\begin{array}{c}0.868 \\
(1.321) \\
{[0.512]}\end{array}$ \\
\hline Savings in piggy bank & 2,519 & 62,864 & $\begin{array}{c}0.466^{* * *} \\
(0.166) \\
{[0.009]}\end{array}$ & 2,322 & 42,182 & $\begin{array}{c}0.891^{* * *} \\
(0.288) \\
{[0.005]}\end{array}$ & 2,135 & 63,510 & $\begin{array}{c}0.772^{* * *} \\
(0.170) \\
{[0.000]}\end{array}$ \\
\hline
\end{tabular}

Notes: $* * *$ significant at $1 \%, * *$ significant at $5 \%, *$ significant at $10 \%$, based on $p$-values unadjusted for multiple-hypothesis testing. Clustered standard errors at the municipality level (in parenthesis). Romano-Wolf adjusted $p$-values (in square brackets). Regressions control only for randomization blocks. The control means column shows non-standardized values. 
Table 14: Impact of LISTA on Psycosocial Indicators - without Controls

\begin{tabular}{|c|c|c|c|c|c|c|c|c|c|}
\hline & \multicolumn{3}{|c|}{ First follow-up } & \multicolumn{3}{|c|}{ Second follow-up } & \multicolumn{3}{|c|}{ Third follow-up } \\
\hline & Obs & Control & Treatment & Obs & Control & Treatment & Obs & Control & Treatment \\
\hline Optimism & & & & 2,241 & 5.785 & $\begin{array}{c}0.090^{*} \\
(0.048) \\
{[0.286]}\end{array}$ & 2,128 & 5.846 & $\begin{array}{c}0.012 \\
(0.048) \\
{[0.812]}\end{array}$ \\
\hline Pessimism & & & & 2,252 & 2.404 & $\begin{array}{c}-0.115^{* *} \\
(0.046) \\
{[0.087]}\end{array}$ & 2,114 & 2.859 & $\begin{array}{c}-0.049 \\
(0.063) \\
{[0.738]}\end{array}$ \\
\hline People trust & & & & 2,284 & 0.052 & $\begin{array}{c}-0.012 \\
(0.010) \\
{[0.458]}\end{array}$ & 2,172 & 0.114 & $\begin{array}{c}-0.021 \\
(0.015) \\
{[0.499]}\end{array}$ \\
\hline More trustworthy of other people & & & & 2,297 & 1.830 & $\begin{array}{c}0.077 \\
(0.048) \\
{[0.389]}\end{array}$ & & & \\
\hline Interested in savings program & & & & 2,232 & 2.974 & $\begin{array}{c}0.044 \\
(0.058) \\
{[0.681]}\end{array}$ & & & \\
\hline $\begin{array}{l}\text { There are lots of ways around } \\
\text { any problem that I am facing now }\end{array}$ & & & & 2,305 & 5.743 & $\begin{array}{c}0.027 \\
(0.063) \\
{[0.681]}\end{array}$ & & & \\
\hline Is meeting her goals & & & & 2,305 & 5.312 & $\begin{array}{c}0.086 \\
(0.053) \\
{[0.389]}\end{array}$ & & & \\
\hline Self-efficacy & & & & & & & 2,180 & 3.017 & $\begin{array}{c}0.044 \\
(0.052) \\
{[0.738]}\end{array}$ \\
\hline Future orientation & & & & & & & 2,180 & 3.255 & $\begin{array}{c}0.067 \\
(0.046) \\
{[0.497]}\end{array}$ \\
\hline Social capital & & & & & & & 2,180 & 1.709 & $\begin{array}{c}0.090 \\
(0.056) \\
{[0.426]}\end{array}$ \\
\hline
\end{tabular}

Notes: *** significant at $1 \%, * *$ significant at $5 \%, *$ significant at $10 \%$, based on $p$-values unadjusted for multiple-hypothesis testing. Clustered standard errors at the municipality level (in parenthesis). Romano-Wolf adjusted $p$-values (in square brackets). Regressions control only for randomization blocks. The control means column shows non-standardized values. 


\section{Results: Treatment-on-the-Treated estimates}

Table 15: Impact of LISTA on Financial Knowledge - ToT

\begin{tabular}{|c|c|c|c|c|c|c|c|c|c|}
\hline & \multicolumn{3}{|c|}{ First follow-up } & \multicolumn{3}{|c|}{ Second follow-up } & \multicolumn{3}{|c|}{ Third follow-up } \\
\hline & Obs & Control & Treatment & Obs & Control & Treatment & Obs & Control & Treatment \\
\hline Knowledge: total score & 2,502 & 5.126 & $\begin{array}{c}0.251^{* * *} \\
(0.040)\end{array}$ & 2,305 & 5.589 & $\begin{array}{c}0.216^{* * *} \\
(0.060)\end{array}$ & 2,180 & 5.330 & $\begin{array}{c}0.177^{* * *} \\
(0.056)\end{array}$ \\
\hline Knowledge: savings section & 2,502 & 2.120 & $\begin{array}{c}0.287^{* * *} \\
(0.042) \\
{[0.000]}\end{array}$ & 2,305 & 2.264 & $\begin{array}{c}0.186^{* * *} \\
(0.059) \\
{[0.004]}\end{array}$ & 2,180 & 2.058 & $\begin{array}{c}0.163^{* * *} \\
(0.063) \\
{[0.017]}\end{array}$ \\
\hline Knowledge: budget section & 2,502 & 1.435 & $\begin{array}{c}0.180^{* * *} \\
(0.046) \\
{[0.000]}\end{array}$ & 2,305 & 1.607 & $\begin{array}{c}0.095^{*} \\
(0.054) \\
{[0.083]}\end{array}$ & 2,180 & 1.541 & $\begin{array}{c}0.180^{* * *} \\
(0.052) \\
{[0.002]}\end{array}$ \\
\hline Knowledge: debt section & 2,502 & 1.572 & $\begin{array}{c}-0.023 \\
(0.054) \\
{[0.683]}\end{array}$ & 2,305 & 1.718 & $\begin{array}{l}0.101^{* *} \\
(0.049) \\
{[0.083]}\end{array}$ & 2,180 & 1.731 & $\begin{array}{c}-0.042 \\
(0.052) \\
{[0.423]}\end{array}$ \\
\hline Knowledge extended: total score & & & & 2,305 & 8.661 & $\begin{array}{c}0.236 * * * \\
(0.066)\end{array}$ & 2,180 & 7.822 & $\begin{array}{c}0.218^{* * *} \\
(0.063)\end{array}$ \\
\hline Knowledge extended: savings & & & & 2,305 & 3.140 & $\begin{array}{c}0.197^{* * *} \\
(0.065) \\
{[0.006]}\end{array}$ & 2,180 & 2.912 & $\begin{array}{c}0.171^{* * *} \\
(0.064) \\
{[0.012]}\end{array}$ \\
\hline Knowledge extended: budget & & & & 2,305 & 2.267 & $\begin{array}{c}0.190^{* * *} \\
(0.056) \\
{[0.004]}\end{array}$ & 2,180 & 1.991 & $\begin{array}{c}0.224^{* * *} \\
(0.062) \\
{[0.000]}\end{array}$ \\
\hline Knowledge extended: debt & & & & 2,305 & 3.254 & $\begin{array}{c}0.084 \\
(0.056) \\
{[0.143]}\end{array}$ & 2,180 & 2.918 & $\begin{array}{c}0.028 \\
(0.048) \\
{[0.557]}\end{array}$ \\
\hline Knowledge extended: math & & & & 2,305 & 1.624 & $\begin{array}{l}0.111^{* *} \\
(0.056) \\
{[0.070]}\end{array}$ & & & \\
\hline
\end{tabular}

Notes: *** significant at $1 \%, * *$ significant at $5 \%, *$ significant at $10 \%$, based on $p$-values unadjusted for multiple-hypothesis testing. Clustered standard errors at the municipality level (in parenthesis) Romano-Wolf adjusted $p$-values (in square brackets). Regressions control for ra 
Table 16: Impact of LISTA on Financial Attitudes - ToT

\begin{tabular}{|c|c|c|c|c|c|c|c|c|c|}
\hline & \multicolumn{3}{|c|}{ First follow-up } & \multicolumn{3}{|c|}{ Second follow-up } & \multicolumn{3}{|c|}{ Third follow-up } \\
\hline & Obs & Control & Treatment & Obs & Control & Treatment & Obs & Control & Treatment \\
\hline Has a savings goal & 2,396 & 0.373 & $\begin{array}{c}0.209^{* * *} \\
(0.026) \\
{[0.000]}\end{array}$ & 2,301 & 0.267 & $\begin{array}{c}0.090^{* * *} \\
(0.028) \\
{[0.000]}\end{array}$ & 2,177 & 0.290 & $\begin{array}{c}0.161^{* * *} \\
(0.028) \\
{[0.000]}\end{array}$ \\
\hline Believes can leave money in MFA account & 1,597 & 0.649 & $\begin{array}{c}0.149^{* * *} \\
(0.024) \\
{[0.000]}\end{array}$ & 1,405 & 0.680 & $\begin{array}{c}0.089 * * * \\
(0.028) \\
{[0.006]}\end{array}$ & 1,441 & 0.734 & $\begin{array}{c}0.067 * * \\
(0.033) \\
{[0.156]}\end{array}$ \\
\hline Trust in bank & 1,749 & 2.726 & $\begin{array}{c}0.256^{* * *} \\
(0.055) \\
{[0.000]}\end{array}$ & 1,588 & 2.627 & $\begin{array}{c}0.245^{* * *} \\
(0.057) \\
{[0.000]}\end{array}$ & 1,528 & 2.593 & $\begin{array}{c}0.110^{*} \\
(0.057) \\
{[0.156]}\end{array}$ \\
\hline Comfort with banks & 1,720 & 2.368 & $\begin{array}{c}0.238^{* * *} \\
(0.057) \\
{[0.001]}\end{array}$ & 1,557 & 2.467 & $\begin{array}{c}0.028 \\
(0.061) \\
{[0.639]}\end{array}$ & 1,510 & 2.603 & $\begin{array}{c}0.115^{*} \\
(0.065) \\
{[0.156]}\end{array}$ \\
\hline Preference: money in bank vs. cash & 1,773 & 3.530 & $\begin{array}{c}0.196^{* * *} \\
(0.047) \\
{[0.001]}\end{array}$ & 1,624 & 2.751 & $\begin{array}{c}0.216^{* * *} \\
(0.055) \\
{[0.000]}\end{array}$ & 1,555 & 2.822 & $\begin{array}{c}0.241^{* * *} \\
(0.069) \\
{[0.002]}\end{array}$ \\
\hline Intertemporal preference: today vs. one month & & & & 1,621 & 3.161 & $\begin{array}{c}-0.200 * * * \\
(0.053) \\
{[0.000]}\end{array}$ & 1,553 & 2.972 & $\begin{array}{c}-0.107^{*} \\
(0.061) \\
{[0.156]}\end{array}$ \\
\hline
\end{tabular}

Notes: $* * *$ significant at $1 \%, * *$ significant at $5 \%, *$ significant at $10 \%$, based on $p$-values unadjusted for multiple-hypothesis testing. Clustered standard errors at the municipality level (in parenthesis). Romano-Wolf adjusted $p$-values (in square brackets). Regressions control for randomization blocks, individual and household characteristics (gender, age, number of member in the household,...) and bank characteristics. The control means column shows non-standardized values. 
Table 17: Impact of LISTA on Financial Practices (ATM, MFA) - ToT

\begin{tabular}{|c|c|c|c|c|c|c|c|c|c|}
\hline & \multicolumn{3}{|c|}{ First follow-up } & \multicolumn{3}{|c|}{ Second follow-up } & \multicolumn{3}{|c|}{ Third follow-up } \\
\hline & Obs & Control & Treatment & Obs & Control & Treatment & Obs & Control & Treatment \\
\hline Manages household finances & 1,712 & 0.928 & $\begin{array}{c}0.020^{*} \\
(0.011) \\
{[0.177]}\end{array}$ & 1,582 & 0.918 & $\begin{array}{l}0.021^{*} \\
(0.012) \\
{[0.367]}\end{array}$ & 1,512 & 0.934 & $\begin{array}{c}0.009 \\
(0.014) \\
{[0.907]}\end{array}$ \\
\hline Keeps written track of accounts & 1,655 & 0.222 & $\begin{array}{c}0.040 \\
(0.025) \\
{[0.187]}\end{array}$ & 1,500 & 0.163 & $\begin{array}{c}0.014 \\
(0.020) \\
{[0.910]}\end{array}$ & 1,451 & 0.346 & $\begin{array}{c}0.025 \\
(0.030) \\
{[0.898]}\end{array}$ \\
\hline Withdrew last MFA transfer & 1,663 & 0.837 & $\begin{array}{l}-0.008 \\
(0.014) \\
{[0.569]}\end{array}$ & 1,577 & 0.784 & $\begin{array}{c}0.011 \\
(0.019) \\
{[0.910]}\end{array}$ & 1,448 & 0.825 & $\begin{array}{c}0.047^{* *} \\
(0.023) \\
{[0.264]}\end{array}$ \\
\hline Accompanied when withdrew & 1,521 & 0.407 & $\begin{array}{c}0.076^{* * *} \\
(0.025) \\
{[0.010]}\end{array}$ & 982 & 0.504 & $\begin{array}{c}0.054 \\
(0.034) \\
{[0.401]}\end{array}$ & 1,415 & 0.413 & $\begin{array}{c}0.043 \\
(0.037) \\
{[0.825]}\end{array}$ \\
\hline Has money in MFA account (today) & & & & 1,237 & 0.357 & $\begin{array}{c}0.077^{*} \\
(0.042) \\
{[0.366]}\end{array}$ & 1,318 & 0.499 & $\begin{array}{c}0.055 \\
(0.043) \\
{[0.789]}\end{array}$ \\
\hline Leaves money in MFA account & & & & 1,384 & 0.366 & $\begin{array}{c}0.081^{* * *} \\
(0.031) \\
{[0.096]}\end{array}$ & 1,411 & 0.425 & $\begin{array}{c}0.023 \\
(0.038) \\
{[0.907]}\end{array}$ \\
\hline Someone helped use ATM & & & & 494 & 0.657 & $\begin{array}{c}0.005 \\
(0.047) \\
{[0.919]}\end{array}$ & 600 & 0.625 & $\begin{array}{c}0.020 \\
(0.041) \\
{[0.907]}\end{array}$ \\
\hline Feels can teach ATM use & & & & 1,563 & 0.395 & $\begin{array}{c}0.068^{* * *} \\
(0.023) \\
{[0.048]}\end{array}$ & 1,508 & 0.544 & $\begin{array}{l}-0.015 \\
(0.022) \\
{[0.907]}\end{array}$ \\
\hline Has taught someone use ATM & & & & 1,563 & 0.201 & $\begin{array}{c}0.056^{* *} \\
(0.027) \\
{[0.248]}\end{array}$ & 1,508 & 0.250 & $\begin{array}{c}0.031 \\
(0.027) \\
{[0.825]}\end{array}$ \\
\hline Has a MFA card & & & & 1,577 & 0.825 & $\begin{array}{c}0.018 \\
(0.027) \\
{[0.910]}\end{array}$ & 1,449 & 0.954 & $\begin{array}{c}0.034^{* * *} \\
(0.013) \\
{[0.073]}\end{array}$ \\
\hline
\end{tabular}

Notes: $* * *$ significant at $1 \%, * *$ significant at $5 \%, *$ significant at $10 \%$, based on $p$-values unadjusted for multiple-hypothesis testing. Clustered standard errors at the municipality level (in parenthesis). Romano-Wolf adjusted $p$-values (in square brackets). Regressions control for randomization blocks, individual and household characteristics (gender, age, number of member in the household,...) and bank characteristics. The control means column shows non-standardized values. 
Table 18: Impact of LISTA on Financial Practices (Budget) - ToT

\begin{tabular}{|c|c|c|c|c|c|c|c|c|c|}
\hline & \multicolumn{3}{|c|}{ First follow-up } & \multicolumn{3}{|c|}{ Second follow-up } & \multicolumn{3}{|c|}{ Third follow-up } \\
\hline & Obs & Control & Treatment & Obs & Control & Treatment & Obs & Control & Treatment \\
\hline \multicolumn{10}{|l|}{ In case of a $350 \mathrm{k}$ emergency } \\
\hline Would use savings & 2,412 & 0.195 & $\begin{array}{c}0.213^{* * *} \\
(0.026) \\
{[0.000]}\end{array}$ & 2,223 & 0.076 & $\begin{array}{c}0.102^{* * *} \\
(0.013) \\
{[0.000]}\end{array}$ & 2,121 & 0.084 & $\begin{array}{c}0.077^{* * *} \\
(0.019) \\
{[0.000]}\end{array}$ \\
\hline Would use loans & 2,412 & 0.751 & $\begin{array}{c}-0.201 * * * \\
(0.027) \\
{[0.000]}\end{array}$ & 2,223 & 0.815 & $\begin{array}{c}-0.132^{* * *} \\
(0.020) \\
{[0.000]}\end{array}$ & 2,121 & 0.840 & $\begin{array}{c}-0.083^{* * *} \\
(0.025) \\
{[0.002]}\end{array}$ \\
\hline Would sell or pawn something & 2,412 & 0.035 & $\begin{array}{c}-0.008 \\
(0.009) \\
{[0.412]}\end{array}$ & 2,223 & 0.098 & $\begin{array}{c}0.027 \\
(0.017) \\
{[0.103]}\end{array}$ & 2,121 & 0.039 & $\begin{array}{c}0.009 \\
(0.012) \\
{[0.715]}\end{array}$ \\
\hline Would look for a job & & & & 2,247 & 0.028 & $\begin{array}{c}-0.016^{* *} \\
(0.007) \\
{[0.049]}\end{array}$ & 2,141 & 0.027 & $\begin{array}{c}-0.000 \\
(0.009) \\
{[0.893]}\end{array}$ \\
\hline \multicolumn{10}{|l|}{ In case of receiving $300 \mathrm{k}$ extra } \\
\hline Would save & & & & 2,305 & 0.854 & $\begin{array}{c}0.055^{* *} \\
(0.022) \\
{[0.059]}\end{array}$ & 2,177 & 0.835 & $\begin{array}{l}0.053^{* *} \\
(0.021) \\
{[0.053]}\end{array}$ \\
\hline Would spend on healthcare or education & & & & 2,305 & 0.083 & $\begin{array}{c}0.010 \\
(0.014) \\
{[0.623]}\end{array}$ & 2,172 & 0.965 & $\begin{array}{c}0.005 \\
(0.011) \\
{[0.739]}\end{array}$ \\
\hline Would build, improve or buy a house & & & & 2,294 & 0.791 & $\begin{array}{l}-0.023 \\
(0.022) \\
{[0.623]}\end{array}$ & 2,172 & 0.804 & $\begin{array}{c}0.020 \\
(0.023) \\
{[0.739]}\end{array}$ \\
\hline Would spend on household expenses & & & & 2,305 & 0.064 & $\begin{array}{c}-0.023^{*} \\
(0.012) \\
{[0.204]}\end{array}$ & 2,175 & 0.843 & $\begin{array}{c}-0.015 \\
(0.021) \\
{[0.739]}\end{array}$ \\
\hline Would invest in business & & & & 2,300 & 0.848 & $\begin{array}{c}0.016 \\
(0.018) \\
{[0.623]}\end{array}$ & 2,176 & 0.899 & $\begin{array}{c}0.027 \\
(0.018) \\
{[0.368]}\end{array}$ \\
\hline Was able to cover household expenses & & & & 2,112 & 0.360 & $\begin{array}{c}0.044^{*} \\
(0.025) \\
{[0.158]}\end{array}$ & 2,004 & 0.373 & $\begin{array}{c}0.096 * * * \\
(0.027) \\
{[0.002]}\end{array}$ \\
\hline Household weekly expenditure & & & & 2,112 & $144,602.704$ & $\begin{array}{c}0.005 \\
(0.055) \\
{[0.909]}\end{array}$ & 1,968 & $155,571.947$ & $\begin{array}{c}-0.010 \\
(0.071) \\
{[0.884]}\end{array}$ \\
\hline
\end{tabular}

Notes: *** significant at $1 \%, * *$ significant at $5 \%, *$ significant at $10 \%$, based on $p$-values unadjusted for multiple-hypothesis testing. Clustered standard errors at the municipality level (in parenthesis). Romano-Wolf adjusted $p$-values (in square brackets). Regressions control for randomization blocks, individual and household characteristics (gender, age, number of member in the household,...) and bank characteristics. The control means column shows non-standardized values. 
Table 19: Impact of LISTA on Financial Performance (Self - Reported) - ToT

\begin{tabular}{|c|c|c|c|c|c|c|c|c|c|}
\hline & \multicolumn{3}{|c|}{ First follow-up } & \multicolumn{3}{|c|}{ Second follow-up } & \multicolumn{3}{|c|}{ Third follow-up } \\
\hline & Obs & Control & Treatment & Obs & Control & Treatment & Obs & Control & Treatment \\
\hline \multicolumn{10}{|l|}{ Panel A: Probability of saving } \\
\hline Has formal or informal savings & 2,502 & 0.600 & $\begin{array}{c}0.182^{* * *} \\
(0.027)\end{array}$ & 2,305 & 0.385 & $\begin{array}{c}0.134^{* * *} \\
(0.022)\end{array}$ & 2,180 & 0.439 & $\begin{array}{c}0.145^{* * *} \\
(0.028)\end{array}$ \\
\hline Has formal savings & 2,502 & 0.106 & $\begin{array}{l}0.038^{* *} \\
(0.016)\end{array}$ & 2,305 & 0.089 & $\begin{array}{c}0.009 \\
(0.014)\end{array}$ & 2,178 & 0.096 & $\begin{array}{c}0.032^{*} \\
(0.017)\end{array}$ \\
\hline Has informal savings & 2,501 & 0.568 & $\begin{array}{c}0.185^{* * *} \\
(0.026)\end{array}$ & 2,304 & 0.336 & $\begin{array}{c}0.132^{* * *} \\
(0.023)\end{array}$ & 2,180 & 0.397 & $\begin{array}{c}0.129^{* * *} \\
(0.026)\end{array}$ \\
\hline Has savings in a bank & 2,488 & 0.054 & $\begin{array}{c}0.036^{* * *} \\
(0.011) \\
{[0.004]}\end{array}$ & 2,299 & 0.061 & $\begin{array}{c}-0.004 \\
(0.011) \\
{[0.711]}\end{array}$ & 2,170 & 0.058 & $\begin{array}{c}0.013 \\
(0.015) \\
{[0.360]}\end{array}$ \\
\hline Has savings in cooperative & 2,481 & 0.059 & $\begin{array}{c}0.021 \\
(0.014) \\
{[0.121]}\end{array}$ & 2,297 & 0.030 & $\begin{array}{c}0.019^{*} \\
(0.010) \\
{[0.107]}\end{array}$ & 2,172 & 0.045 & $\begin{array}{c}0.028^{* * *} \\
(0.009) \\
{[0.007]}\end{array}$ \\
\hline Has savings in piggy bank & 2,492 & 0.559 & $\begin{array}{c}0.185^{* * *} \\
(0.026) \\
{[0.000]}\end{array}$ & 2,298 & 0.326 & $\begin{array}{c}0.127^{* * *} \\
(0.023) \\
{[0.000]}\end{array}$ & 2,173 & 0.367 & $\begin{array}{c}0.119^{* * *} \\
(0.021) \\
{[0.000]}\end{array}$ \\
\hline \multicolumn{10}{|l|}{ Panel B: Tobit estimates for savings } \\
\hline Total formal and informal savings & 2,502 & $116,452.128$ & $\begin{array}{c}0.641^{* * *} \\
(0.203)\end{array}$ & 2,305 & $130,451.403$ & $\begin{array}{l}1.015^{* *} \\
(0.413)\end{array}$ & 2,180 & $155,136.981$ & $\begin{array}{c}1.126^{* * *} \\
(0.355)\end{array}$ \\
\hline Total formal savings & 2,502 & $36,004.654$ & $\begin{array}{c}1.475^{*} \\
(0.828)\end{array}$ & 2,305 & $57,237.223$ & $\begin{array}{c}1.132 \\
(1.474)\end{array}$ & 2,179 & $52,123.774$ & $\begin{array}{c}1.669 \\
(1.242)\end{array}$ \\
\hline Total informal savings & 2,502 & $74,136.303$ & $\begin{array}{c}0.632^{* * *} \\
(0.206)\end{array}$ & 2,305 & $53,193.501$ & $\begin{array}{c}0.967^{* * *} \\
(0.329)\end{array}$ & 2,120 & $91,590.208$ & $\begin{array}{c}1.301^{* * *} \\
(0.319)\end{array}$ \\
\hline Savings in a bank & 2,502 & $16,009.309$ & $\begin{array}{c}3.891^{* * *} \\
(1.341) \\
{[0.009]}\end{array}$ & 2,305 & $36,068.833$ & $\begin{array}{c}0.302 \\
(2.452) \\
{[0.912]}\end{array}$ & 2,172 & $23,701.967$ & $\begin{array}{c}0.733 \\
(1.583) \\
{[0.028]}\end{array}$ \\
\hline Savings in piggy bank & 2,502 & $65,065.824$ & $\begin{array}{c}0.579^{* * *} \\
(0.216) \\
{[0.016]}\end{array}$ & 2,305 & $42,344.165$ & $\begin{array}{c}1.005^{* * *} \\
(0.337) \\
{[0.002]}\end{array}$ & 2,120 & $63,980.339$ & $\begin{array}{c}0.982^{* * *} \\
(0.201) \\
{[0.000]}\end{array}$ \\
\hline
\end{tabular}

Notes: *** significant at $1 \%, * *$ significant at $5 \%, *$ significant at $10 \%$, based on $p$-values unadjusted for multiple-hypothesis testing. Clustered standard errors at the municipality level (in parenthesis). Romano-Wolf adjusted $p$-values (in square brackets). Regressions control for randomization blocks, individual and household characteristics (gender, age, number of member in the household,...) and bank characteristics. The control means column shows non-standardized values. 
Table 20: Impact of LISTA on Psycosocial Indicators - ToT

\begin{tabular}{|c|c|c|c|c|c|c|c|c|c|}
\hline & \multicolumn{3}{|c|}{ First follow-up } & \multicolumn{3}{|c|}{ Second follow-up } & \multicolumn{3}{|c|}{ Third follow-up } \\
\hline & Obs & Control & Treatment & Obs & Control & Treatment & Obs & Control & Treatment \\
\hline Optimism & & & & 2,241 & 5.806 & $\begin{array}{c}0.115^{* *} \\
(0.052) \\
{[0.157]}\end{array}$ & 2,128 & 5.850 & $\begin{array}{c}0.034 \\
(0.057) \\
{[0.680]}\end{array}$ \\
\hline Pessimism & & & & 2,252 & 2.355 & $\begin{array}{c}-0.145^{* * *} \\
(0.053) \\
{[0.038]}\end{array}$ & 2,114 & 2.857 & $\begin{array}{l}-0.070 \\
(0.075) \\
{[0.680]}\end{array}$ \\
\hline People trust & & & & 2,284 & 0.046 & $\begin{array}{l}-0.016 \\
(0.011) \\
{[0.356]}\end{array}$ & 2,172 & 0.105 & $\begin{array}{l}-0.030 \\
(0.019) \\
{[0.466]}\end{array}$ \\
\hline More trustworthy of other people & & & & 2,297 & 1.840 & $\begin{array}{c}0.097^{*} \\
(0.052) \\
{[0.276]}\end{array}$ & & & \\
\hline $\begin{array}{l}\text { There are lots of ways around } \\
\text { any problem that I am facing now }\end{array}$ & & & & 2,305 & 5.750 & $\begin{array}{c}0.031 \\
(0.071) \\
{[0.694]}\end{array}$ & & & \\
\hline Is meeting her goals & & & & 2,305 & 5.323 & $\begin{array}{c}0.107^{*} \\
(0.062) \\
{[0.279]}\end{array}$ & & & \\
\hline Self-efficacy & & & & & & & 2,180 & 3.011 & $\begin{array}{c}0.060 \\
(0.065) \\
{[0.680]}\end{array}$ \\
\hline Future orientation & & & & & & & 2,180 & 3.262 & $\begin{array}{c}0.082 \\
(0.054) \\
{[0.466]}\end{array}$ \\
\hline
\end{tabular}

Notes: $* * *$ significant at $1 \%, * *$ significant at $5 \%, *$ significant at $10 \%$, based on $p$-values unadjusted for multiple-hypothesis testing. Clustered standard errors at the municipality level (in parenthesis). Romano-Wolf adjusted $p$-values (in square brackets). Regressions control for randomization blocks, individual and household characteristics (gender, age, number of member in the household,...) and bank characteristics. The control means column shows non-standardized values. 


\section{Results: Heterogeneous Effects}

Table 21: Heterogeneous effects: First follow-up Tablet effect on Financial Knowledge

\begin{tabular}{lccccccc}
\hline & & \multicolumn{3}{c}{ Area } & \multicolumn{2}{c}{ Region } & \multicolumn{2}{c}{ Schooling } \\
& Total & Urban & Rural & Caribe & Pacifico & Primary & Secondary \\
& $(1)$ & $(2)$ & $(3)$ & $(4)$ & $(5)$ & $(6)$ & $(7)$ \\
\hline Knowledge: total score & $0.201^{* * *}$ & $0.160^{* * *}$ & $0.240^{* * *}$ & $0.180^{* * *}$ & $0.258^{* * *}$ & $0.253^{* * *}$ & $0.173^{* * *}$ \\
& $(0.033)$ & $(0.049)$ & $(0.041)$ & $(0.038)$ & $(0.060)$ & $(0.050)$ & $(0.046)$ \\
& $0.230^{* * *}$ & $0.191^{* * *}$ & $0.260^{* * *}$ & $0.184^{* * *}$ & $0.337^{* * *}$ & $0.266^{* * *}$ & $0.205^{* * *}$ \\
Knowledge: savings section & $(0.035)$ & $(0.048)$ & $(0.042)$ & $(0.043)$ & $(0.046)$ & $(0.045)$ & $(0.050)$ \\
& $0.144^{* * *}$ & $0.139^{* * *}$ & $0.157^{* * *}$ & $0.144^{* * *}$ & $0.152^{*}$ & $0.148^{* * *}$ & $0.152^{* * *}$ \\
& $(0.038)$ & $(0.051)$ & $(0.049)$ & $(0.040)$ & $(0.080)$ & $(0.050)$ & $(0.049)$ \\
Knowledge: budget section & -0.018 & -0.047 & 0.011 & -0.002 & -0.045 & 0.038 & -0.049 \\
& $(0.044)$ & $(0.047)$ & $(0.064)$ & $(0.040)$ & $(0.106)$ & $(0.072)$ & $(0.056)$
\end{tabular}

Knowledge extended: total score

Knowledge extended: savings

Knowledge extended: budget

Knowledge extended: debt

Knowledge extended: math

Notes: *** significant at $1 \%, * *$ significant at $5 \%, *$ significant at $10 \%$ (based on $p$-values unadjusted for multiple-hypothesis testing). Clustered standard errors at the municipality level in parenthesis. Column (1) shows regression coefficient of the treatment for the whole sample (average effect). Columns (2) to (7) show coefficients of the treatment in the regression for each sub-sample. 
Table 22: Heterogeneous effects: First follow-up Tablet effect on Financial Knowledge

\begin{tabular}{|c|c|c|c|c|c|c|c|c|c|}
\hline & \multirow[b]{2}{*}{$\begin{array}{c}\text { Total } \\
(1)\end{array}$} & \multicolumn{4}{|c|}{ Interactions with SISBEN points quartiles } & \multicolumn{4}{|c|}{ Interactions with age quartiles } \\
\hline & & $\begin{array}{c}\text { Treat } \\
(2)\end{array}$ & $\begin{array}{c}\text { Treat*Q2 } \\
(3)\end{array}$ & $\begin{array}{c}\text { Treat* }{ }^{*} 3 \\
(4)\end{array}$ & $\begin{array}{c}\text { Treat* }{ }^{*} 4 \\
(5)\end{array}$ & $\begin{array}{l}\text { Treat } \\
(6)\end{array}$ & $\begin{array}{c}\text { Treat*Q2 } \\
(7)\end{array}$ & $\begin{array}{c}\text { Treat*Q3 } \\
(8)\end{array}$ & $\begin{array}{c}\text { Treat*Q4 } \\
(9)\end{array}$ \\
\hline Knowledge: total score & $\begin{array}{c}0.201^{* * *} \\
(0.033)\end{array}$ & $\begin{array}{c}0.169 * * \\
(0.070)\end{array}$ & $\begin{array}{c}0.054 \\
(0.111)\end{array}$ & $\begin{array}{l}-0.016 \\
(0.115)\end{array}$ & $\begin{array}{c}0.054 \\
(0.101)\end{array}$ & $\begin{array}{c}0.151^{* *} \\
(0.074)\end{array}$ & $\begin{array}{l}-0.000 \\
(0.102)\end{array}$ & $\begin{array}{c}0.066 \\
(0.104)\end{array}$ & $\begin{array}{c}0.128 \\
(0.111)\end{array}$ \\
\hline Knowledge: savings section & $\begin{array}{c}0.230^{* * *} \\
(0.035)\end{array}$ & $\begin{array}{c}0.245^{* * *} \\
(0.064)\end{array}$ & $\begin{array}{c}-0.082 \\
(0.104)\end{array}$ & $\begin{array}{c}-0.008 \\
(0.104)\end{array}$ & $\begin{array}{c}-0.009 \\
(0.102)\end{array}$ & $\begin{array}{c}0.148^{*} \\
(0.078)\end{array}$ & $\begin{array}{l}-0.020 \\
(0.112)\end{array}$ & $\begin{array}{c}0.129 \\
(0.104)\end{array}$ & $\begin{array}{c}0.208^{*} \\
(0.109)\end{array}$ \\
\hline Knowledge: budget section & $\begin{array}{c}0.144^{* * *} \\
(0.038)\end{array}$ & $\begin{array}{c}0.059 \\
(0.064)\end{array}$ & $\begin{array}{c}0.175^{*} \\
(0.100)\end{array}$ & $\begin{array}{c}0.091 \\
(0.100)\end{array}$ & $\begin{array}{c}0.077 \\
(0.094)\end{array}$ & $\begin{array}{c}0.142 \\
(0.086)\end{array}$ & $\begin{array}{c}-0.044 \\
(0.113)\end{array}$ & $\begin{array}{c}0.079 \\
(0.114)\end{array}$ & $\begin{array}{c}-0.026 \\
(0.106)\end{array}$ \\
\hline Knowledge: debt section & $\begin{array}{l}-0.018 \\
(0.044)\end{array}$ & $\begin{array}{l}-0.024 \\
(0.089)\end{array}$ & $\begin{array}{c}0.049 \\
(0.112)\end{array}$ & $\begin{array}{l}-0.106 \\
(0.121)\end{array}$ & $\begin{array}{c}0.049 \\
(0.125)\end{array}$ & $\begin{array}{l}-0.013 \\
(0.075)\end{array}$ & $\begin{array}{c}0.066 \\
(0.112)\end{array}$ & $\begin{array}{l}-0.103 \\
(0.107)\end{array}$ & $\begin{array}{c}0.021 \\
(0.128)\end{array}$ \\
\hline
\end{tabular}

Knowledge extended: total score

Knowledge extended: savings

Knowledge extended: budget

Knowledge extended: debt

Knowledge extended: math

Notes: $* * *$ significant at $1 \%, * *$ significant at $5 \%, *$ significant at $10 \%$ (based on $p$-values unadjusted for multiple-hypothesis testing). Clustered standard errors at the municipality level in parenthesis. Column (1) shows regression coefficient of the treatment for the whole sample (average effect). Columns (2) to (5) and (6) to (9) show coefficients of the regression that includes interaction terms of the treatment variable with SISBEN points and age, respectively. 
Table 23: Heterogeneous effects: Second follow-up Tablet effect on Financial Knowledge

\begin{tabular}{lccccccc}
\hline & \multicolumn{4}{c}{ Area } & \multicolumn{2}{c}{ Region } & \multicolumn{2}{c}{ Schooling } \\
& Total & Urban & Rural & Caribe & Pacifico & Primary & Secondary \\
& $(1)$ & $(2)$ & $(3)$ & $(4)$ & $(5)$ & $(6)$ & $(7)$ \\
\hline Knowledge: total score & $0.177^{* * *}$ & $0.115^{*}$ & $0.238^{* * *}$ & $0.118^{* *}$ & $0.332^{* * *}$ & $0.242^{* * *}$ & $0.125^{* *}$ \\
& $(0.050)$ & $(0.058)$ & $(0.072)$ & $(0.056)$ & $(0.096)$ & $(0.078)$ & $(0.059)$ \\
& $0.153^{* * *}$ & $0.129^{*}$ & $0.189^{* * *}$ & $0.103^{*}$ & $0.305^{* * *}$ & $0.217^{* * *}$ & 0.103 \\
Knowledge: savings section & $(0.050)$ & $(0.071)$ & $(0.065)$ & $(0.057)$ & $(0.104)$ & $(0.071)$ & $(0.063)$ \\
& $0.078^{*}$ & 0.050 & $0.106^{*}$ & 0.055 & $0.151^{*}$ & $0.138^{* *}$ & 0.030 \\
Knowledge: budget section & $(0.045)$ & $(0.055)$ & $(0.059)$ & $(0.055)$ & $(0.082)$ & $(0.066)$ & $(0.051)$ \\
& $0.083^{* *}$ & 0.006 & $0.136^{* *}$ & 0.049 & 0.120 & 0.065 & $0.094^{*}$ \\
Knowledge: debt section & $(0.041)$ & $(0.050)$ & $(0.066)$ & $(0.047)$ & $(0.074)$ & $(0.061)$ & $(0.052)$ \\
& $0.194^{* * *}$ & 0.108 & $0.280^{* * *}$ & $0.136^{* *}$ & $0.346^{* * *}$ & $0.271^{* * *}$ & $0.125^{* *}$ \\
Knowledge extended: total score & $(0.055)$ & $(0.072)$ & $(0.070)$ & $(0.062)$ & $(0.107)$ & $(0.075)$ & $(0.062)$ \\
& $0.162^{* * *}$ & 0.116 & $0.210^{* * *}$ & 0.092 & $0.356^{* * *}$ & $0.224^{* * *}$ & $0.111^{*}$ \\
Knowledge extended: savings & $(0.054)$ & $(0.075)$ & $(0.070)$ & $(0.057)$ & $(0.124)$ & $(0.072)$ & $(0.064)$ \\
& $0.157^{* * *}$ & $0.100^{*}$ & $0.215^{* * *}$ & $0.147^{* *}$ & $0.211^{* *}$ & $0.203^{* * *}$ & $0.111^{* *}$ \\
Knowledge extended: budget & $(0.046)$ & $(0.059)$ & $(0.061)$ & $(0.056)$ & $(0.090)$ & $(0.062)$ & $(0.051)$ \\
& 0.069 & -0.003 & $0.135^{* *}$ & 0.036 & 0.113 & $0.112^{*}$ & 0.027 \\
Knowledge extended: debt & $(0.047)$ & $(0.071)$ & $(0.065)$ & $(0.054)$ & $(0.086)$ & $(0.067)$ & $(0.064)$ \\
& $0.091^{*}$ & 0.013 & $0.188^{* * *}$ & 0.057 & $0.168^{*}$ & $0.116^{*}$ & 0.082 \\
Knowledge extended: math & $(0.047)$ & $(0.073)$ & $(0.051)$ & $(0.061)$ & $(0.081)$ & $(0.066)$ & $(0.056)$ \\
& & & & & & &
\end{tabular}

Notes: *** significant at $1 \%, * *$ significant at $5 \%, *$ significant at $10 \%$ (based on $p$-values unadjusted for multiple-hypothesis testing). Clustered standard errors at the municipality level in parenthesis. Column (1) shows regression coefficient of the treatment for the whole sample (average effect). Columns (2) to (7) show coefficients of the treatment in the regression for each sub-sample. 
Table 24: Heterogeneous effects: Second follow-up Tablet effect on Financial Knowledge

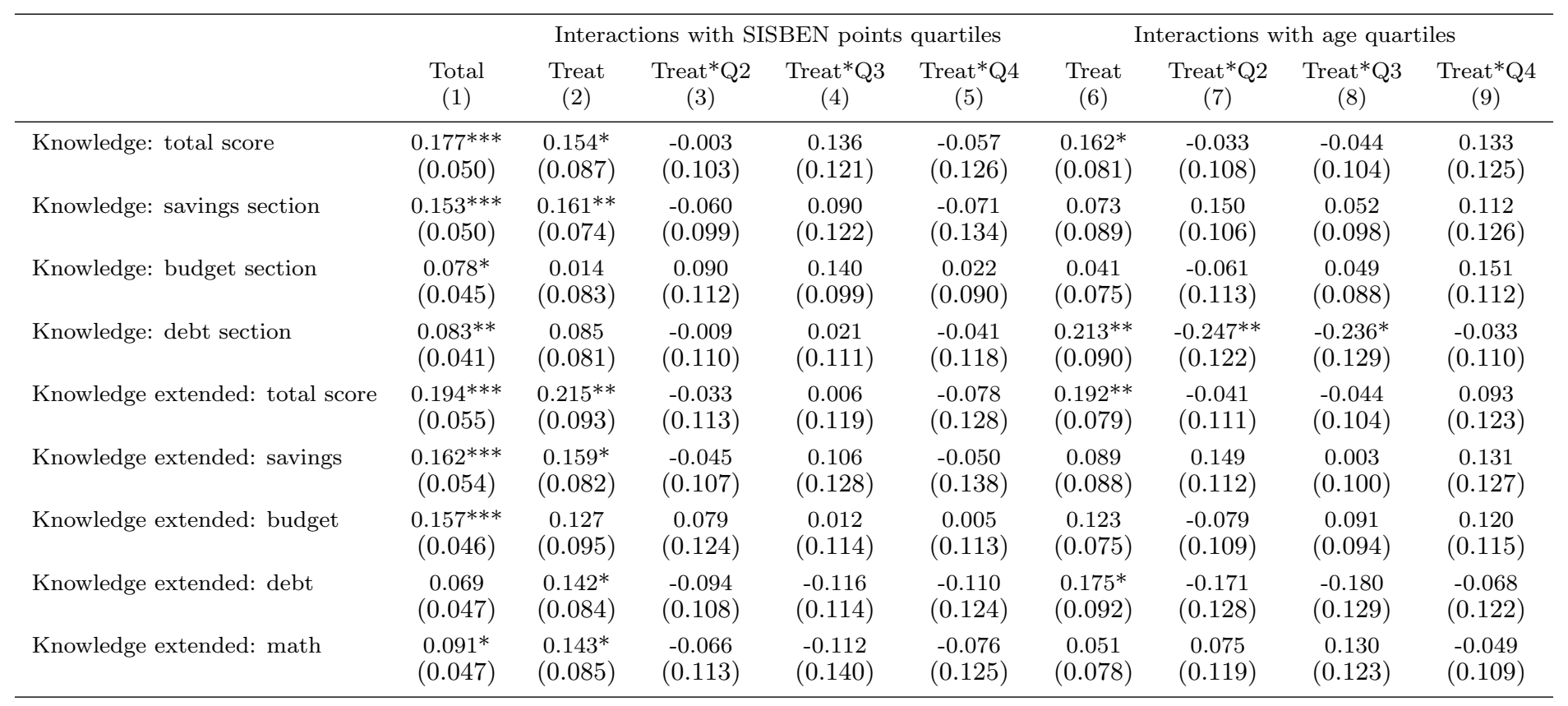

Notes: $* * *$ significant at $1 \%, * *$ significant at $5 \%, *$ significant at $10 \%$ (based on $p$-values unadjusted for multiple-hypothesis testing). Clustered standard errors at the municipality level in parenthesis. Column (1) shows regression coefficient of the treatment for the whole sample (average effect). Columns (2) to (5) and (6) to (9) show coefficients of the regression that includes interaction terms of the treatment variable with SISBEN points and age, respectively. 
Table 25: Heterogeneous effects: Third follow-up Tablet effect on Financial Knowledge

\begin{tabular}{|c|c|c|c|c|c|c|c|}
\hline & \multirow[b]{2}{*}{$\begin{array}{c}\text { Total } \\
(1)\end{array}$} & \multicolumn{2}{|c|}{ Area } & \multicolumn{2}{|c|}{ Region } & \multicolumn{2}{|c|}{ Schooling } \\
\hline & & $\begin{array}{l}\text { Urban } \\
(2)\end{array}$ & $\begin{array}{c}\text { Rural } \\
(3)\end{array}$ & $\begin{array}{c}\text { Caribe } \\
(4)\end{array}$ & $\begin{array}{c}\text { Pacifico } \\
\text { (5) }\end{array}$ & $\begin{array}{c}\text { Primary } \\
(6)\end{array}$ & $\begin{array}{c}\text { Secondary } \\
(7)\end{array}$ \\
\hline Knowledge: total score & $\begin{array}{c}0.140^{* * *} \\
(0.045)\end{array}$ & $\begin{array}{c}0.112^{*} \\
(0.062)\end{array}$ & $\begin{array}{l}0.152^{* *} \\
(0.065)\end{array}$ & $\begin{array}{c}0.089^{*} \\
(0.053)\end{array}$ & $\begin{array}{c}0.265^{* * *} \\
(0.077)\end{array}$ & $\begin{array}{l}0.150^{* *} \\
(0.059)\end{array}$ & $\begin{array}{l}0.125^{* *} \\
(0.058)\end{array}$ \\
\hline Knowledge: savings section & $\begin{array}{l}0.129^{* *} \\
(0.050)\end{array}$ & $\begin{array}{c}0.106^{*} \\
(0.062)\end{array}$ & $\begin{array}{l}0.153^{* *} \\
(0.075)\end{array}$ & $\begin{array}{c}0.064 \\
(0.060)\end{array}$ & $\begin{array}{c}0.306^{* * *} \\
(0.081)\end{array}$ & $\begin{array}{l}0.137^{* *} \\
(0.059)\end{array}$ & $\begin{array}{c}0.114^{*} \\
(0.063)\end{array}$ \\
\hline Knowledge: budget section & $\begin{array}{c}0.143^{* * *} \\
(0.042)\end{array}$ & $\begin{array}{c}0.089 \\
(0.063)\end{array}$ & $\begin{array}{c}0.183^{* * *} \\
(0.060)\end{array}$ & $\begin{array}{c}0.157^{* * *} \\
(0.051)\end{array}$ & $\begin{array}{c}0.103 \\
(0.062)\end{array}$ & $\begin{array}{c}0.158^{* * *} \\
(0.058)\end{array}$ & $\begin{array}{l}0.134^{* *} \\
(0.052)\end{array}$ \\
\hline Knowledge: debt section & $\begin{array}{c}-0.033 \\
(0.042)\end{array}$ & $\begin{array}{c}-0.004 \\
(0.058)\end{array}$ & $\begin{array}{c}-0.084 \\
(0.068)\end{array}$ & $\begin{array}{c}-0.062 \\
(0.052)\end{array}$ & $\begin{array}{c}0.017 \\
(0.064)\end{array}$ & $\begin{array}{c}-0.039 \\
(0.056)\end{array}$ & $\begin{array}{c}-0.035 \\
(0.056)\end{array}$ \\
\hline Knowledge extended: total score & $\begin{array}{c}0.173^{* * *} \\
(0.051)\end{array}$ & $\begin{array}{c}0.141^{*} \\
(0.072)\end{array}$ & $\begin{array}{c}0.183^{* * *} \\
(0.063)\end{array}$ & $\begin{array}{l}0.135^{* *} \\
(0.060)\end{array}$ & $\begin{array}{l}0.258^{* *} \\
(0.091)\end{array}$ & $\begin{array}{c}0.218^{* * *} \\
(0.061)\end{array}$ & $\begin{array}{c}0.119^{*} \\
(0.062)\end{array}$ \\
\hline Knowledge extended: savings & $\begin{array}{l}0.136^{* *} \\
(0.051)\end{array}$ & $\begin{array}{c}0.100 \\
(0.067)\end{array}$ & $\begin{array}{l}0.161^{* *} \\
(0.073)\end{array}$ & $\begin{array}{c}0.075 \\
(0.060)\end{array}$ & $\begin{array}{c}0.285^{* * *} \\
(0.098)\end{array}$ & $\begin{array}{c}0.178^{* * *} \\
(0.055)\end{array}$ & $\begin{array}{c}0.093 \\
(0.070)\end{array}$ \\
\hline Knowledge extended: budget & $\begin{array}{c}0.177^{* * *} \\
(0.049)\end{array}$ & $\begin{array}{l}0.154^{* *} \\
(0.067)\end{array}$ & $\begin{array}{c}0.196^{* * *} \\
(0.058)\end{array}$ & $\begin{array}{c}0.183^{* * *} \\
(0.060)\end{array}$ & $\begin{array}{l}0.164^{* *} \\
(0.069)\end{array}$ & $\begin{array}{c}0.204^{* * *} \\
(0.059)\end{array}$ & $\begin{array}{l}0.143^{* *} \\
(0.059)\end{array}$ \\
\hline Knowledge extended: debt & $\begin{array}{c}0.023 \\
(0.039)\end{array}$ & $\begin{array}{c}0.020 \\
(0.058)\end{array}$ & $\begin{array}{c}-0.002 \\
(0.061)\end{array}$ & $\begin{array}{c}0.005 \\
(0.046)\end{array}$ & $\begin{array}{c}0.049 \\
(0.077)\end{array}$ & $\begin{array}{c}0.040 \\
(0.056)\end{array}$ & $\begin{array}{c}-0.006 \\
(0.055)\end{array}$ \\
\hline
\end{tabular}

Notes: $* * *$ significant at $1 \%, * *$ significant at $5 \%, *$ significant at $10 \%$ (based on $p$-values unadjusted for multiple-hypothesis testing). Clustered standard errors at the municipality level in parenthesis. Column (1) shows regression coefficient of the treatment for the whole sample (average effect). Columns (2) to (7) show coefficients of the treatment in the regression for each sub-sample. 
Table 26: Heterogeneous effects: Third follow-up Tablet effect on Financial Knowledge

\begin{tabular}{|c|c|c|c|c|c|c|c|c|c|}
\hline & \multirow[b]{2}{*}{$\begin{array}{c}\text { Total } \\
(1)\end{array}$} & \multicolumn{4}{|c|}{ Interactions with SISBEN points quartiles } & \multicolumn{4}{|c|}{ Interactions with age quartiles } \\
\hline & & $\begin{array}{l}\text { Treat } \\
(2)\end{array}$ & $\begin{array}{c}\text { Treat*Q2 } \\
\text { (3) }\end{array}$ & $\begin{array}{c}\text { Treat*Q3 } \\
\text { (4) }\end{array}$ & $\begin{array}{c}\text { Treat*Q4 } \\
\text { (5) }\end{array}$ & $\begin{array}{c}\text { Treat } \\
(6)\end{array}$ & $\begin{array}{c}\text { Treat*Q2 } \\
\text { (7) }\end{array}$ & $\begin{array}{c}\text { Treat*Q3 } \\
\text { (8) }\end{array}$ & $\begin{array}{c}\text { Treat* }{ }^{*} 4 \\
\text { (9) }\end{array}$ \\
\hline Knowledge: total score & $\begin{array}{c}0.140^{* * *} \\
(0.045)\end{array}$ & $\begin{array}{c}0.134^{*} \\
(0.077)\end{array}$ & $\begin{array}{c}0.088 \\
(0.110)\end{array}$ & $\begin{array}{c}0.018 \\
(0.126)\end{array}$ & $\begin{array}{c}-0.093 \\
(0.122)\end{array}$ & $\begin{array}{c}0.188^{* * *} \\
(0.062)\end{array}$ & $\begin{array}{c}-0.023 \\
(0.094)\end{array}$ & $\begin{array}{c}-0.097 \\
(0.109)\end{array}$ & $\begin{array}{c}-0.067 \\
(0.098)\end{array}$ \\
\hline Knowledge: savings section & $\begin{array}{l}0.129^{* *} \\
(0.050)\end{array}$ & $\begin{array}{c}0.024 \\
(0.084)\end{array}$ & $\begin{array}{l}0.224^{* *} \\
(0.111)\end{array}$ & $\begin{array}{c}0.191 \\
(0.130)\end{array}$ & $\begin{array}{c}0.029 \\
(0.125)\end{array}$ & $\begin{array}{l}0.163^{* *} \\
(0.081)\end{array}$ & $\begin{array}{c}-0.037 \\
(0.098)\end{array}$ & $\begin{array}{c}-0.073 \\
(0.114)\end{array}$ & $\begin{array}{c}-0.025 \\
(0.105)\end{array}$ \\
\hline Knowledge: budget section & $\begin{array}{c}0.143^{* * *} \\
(0.042)\end{array}$ & $\begin{array}{l}0.168^{* *} \\
(0.079)\end{array}$ & $\begin{array}{c}-0.008 \\
(0.131)\end{array}$ & $\begin{array}{c}-0.027 \\
(0.120)\end{array}$ & $\begin{array}{c}-0.110 \\
(0.128)\end{array}$ & $\begin{array}{c}0.124 \\
(0.075)\end{array}$ & $\begin{array}{c}0.055 \\
(0.104)\end{array}$ & $\begin{array}{c}0.056 \\
(0.088)\end{array}$ & $\begin{array}{c}-0.031 \\
(0.099)\end{array}$ \\
\hline Knowledge: debt section & $\begin{array}{c}-0.033 \\
(0.042)\end{array}$ & $\begin{array}{c}0.085 \\
(0.087)\end{array}$ & $\begin{array}{c}-0.133 \\
(0.119)\end{array}$ & $\begin{array}{c}-0.218 \\
(0.142)\end{array}$ & $\begin{array}{c}-0.134 \\
(0.139)\end{array}$ & $\begin{array}{c}0.040 \\
(0.065)\end{array}$ & $\begin{array}{c}-0.054 \\
(0.109)\end{array}$ & $\begin{array}{c}-0.161 \\
(0.115)\end{array}$ & $\begin{array}{c}-0.077 \\
(0.102)\end{array}$ \\
\hline Knowledge extended: total score & $\begin{array}{c}0.173^{* * *} * \\
(0.051)\end{array}$ & $\begin{array}{l}0.178^{* *} \\
(0.084)\end{array}$ & $\begin{array}{c}0.050 \\
(0.116)\end{array}$ & $\begin{array}{c}0.002 \\
(0.114)\end{array}$ & $\begin{array}{c}-0.097 \\
(0.113)\end{array}$ & $\begin{array}{c}0.203^{* * *} \\
(0.073)\end{array}$ & $\begin{array}{c}-0.048 \\
(0.105)\end{array}$ & $\begin{array}{c}-0.052 \\
(0.103)\end{array}$ & $\begin{array}{c}-0.020 \\
(0.096)\end{array}$ \\
\hline Knowledge extended: savings & $\begin{array}{l}0.136^{* *} \\
(0.051)\end{array}$ & $\begin{array}{c}0.019 \\
(0.084)\end{array}$ & $\begin{array}{c}0.193^{*} \\
(0.115)\end{array}$ & $\begin{array}{c}0.218^{*} \\
(0.128)\end{array}$ & $\begin{array}{c}0.081 \\
(0.121)\end{array}$ & $\begin{array}{c}0.155^{*} \\
(0.084)\end{array}$ & $\begin{array}{c}-0.061 \\
(0.098)\end{array}$ & $\begin{array}{c}-0.054 \\
(0.111)\end{array}$ & $\begin{array}{c}0.032 \\
(0.107)\end{array}$ \\
\hline
\end{tabular}

Notes: *** significant at $1 \%, * *$ significant at $5 \%, *$ significant at $10 \%$ (based on $p$-values unadjusted for multiple-hypothesis testing). Clustered standard errors at the municipality level in parenthesis. Column (1) shows regression coefficient of the treatment for the whole sample (average effect). Columns (2) to (5) and (6) to (9) show coefficients of the regression that includes interaction terms of the treatment variable with SISBEN points and age, respectively. 
Table 27: Heterogeneous effects: First follow-up Tablet effect on Financial Attitudes

\begin{tabular}{|c|c|c|c|c|c|c|c|}
\hline & \multirow[b]{2}{*}{$\begin{array}{c}\text { Total } \\
(1)\end{array}$} & \multicolumn{2}{|c|}{ Area } & \multicolumn{2}{|c|}{ Region } & \multicolumn{2}{|c|}{ Schooling } \\
\hline & & $\begin{array}{l}\text { Urban } \\
(2)\end{array}$ & $\begin{array}{c}\text { Rural } \\
(3)\end{array}$ & $\begin{array}{c}\text { Caribe } \\
(4)\end{array}$ & $\begin{array}{c}\text { Pacifico } \\
(5)\end{array}$ & $\begin{array}{c}\text { Primary } \\
(6)\end{array}$ & $\begin{array}{c}\text { Secondary } \\
(7)\end{array}$ \\
\hline Has a savings goal & $\begin{array}{c}0.167^{* * *} \\
(0.028)\end{array}$ & $\begin{array}{c}0.154^{* * *} \\
(0.036)\end{array}$ & $\begin{array}{c}0.175^{* * *} \\
(0.040)\end{array}$ & $\begin{array}{c}0.189^{* * *} \\
(0.028)\end{array}$ & $\begin{array}{c}0.118 \\
(0.070)\end{array}$ & $\begin{array}{c}0.186^{* * *} \\
(0.040)\end{array}$ & $\begin{array}{c}0.141^{* * *} \\
(0.035)\end{array}$ \\
\hline Believes can leave money in MFA account & $\begin{array}{c}0.121^{* * *} \\
(0.020)\end{array}$ & $\begin{array}{c}0.126^{* * *} \\
(0.024)\end{array}$ & $\begin{array}{c}0.115^{* * *} \\
(0.031)\end{array}$ & $\begin{array}{c}0.112^{* * *} \\
(0.024)\end{array}$ & $\begin{array}{c}0.129^{* * *} \\
(0.035)\end{array}$ & $\begin{array}{c}0.101^{* * *} \\
(0.030)\end{array}$ & $\begin{array}{c}0.147^{* * *} \\
(0.025)\end{array}$ \\
\hline Trust in bank & $\begin{array}{c}0.204^{* * *} \\
(0.046)\end{array}$ & $\begin{array}{l}0.134^{* *} \\
(0.066)\end{array}$ & $\begin{array}{c}0.276^{* * *} \\
(0.065)\end{array}$ & $\begin{array}{c}0.216^{* * *} \\
(0.060)\end{array}$ & $\begin{array}{c}0.121^{*} \\
(0.060)\end{array}$ & $\begin{array}{c}0.195^{* * *} \\
(0.069)\end{array}$ & $\begin{array}{c}0.189^{* * *} \\
(0.055)\end{array}$ \\
\hline Comfort with banks & $\begin{array}{c}0.190^{* * *} \\
(0.046)\end{array}$ & $\begin{array}{c}0.179^{* * *} \\
(0.056)\end{array}$ & $\begin{array}{c}0.193^{* * *} \\
(0.067)\end{array}$ & $\begin{array}{c}0.250^{* * *} \\
(0.055)\end{array}$ & $\begin{array}{c}0.056 \\
(0.065)\end{array}$ & $\begin{array}{l}0.166^{* *} \\
(0.066)\end{array}$ & $\begin{array}{c}0.186^{* * *} \\
(0.066)\end{array}$ \\
\hline Preference: money in bank vs. cash & $\begin{array}{c}0.156^{* * *} \\
(0.038)\end{array}$ & $\begin{array}{c}0.226^{* * *} \\
(0.061)\end{array}$ & $\begin{array}{c}0.063 \\
(0.054)\end{array}$ & $\begin{array}{c}0.208^{* * *} \\
(0.045)\end{array}$ & $\begin{array}{c}0.042 \\
(0.071)\end{array}$ & $\begin{array}{c}0.202^{* * *} \\
(0.065)\end{array}$ & $\begin{array}{l}0.122^{* *} \\
(0.053)\end{array}$ \\
\hline
\end{tabular}

Intertemporal preference: today vs. one month

Notes: *** significant at $1 \%,{ }^{*}$ significant at $5 \%,{ }^{*}$ significant at $10 \%$ (based on $p$-values unadjusted for multiple-hypothesis testing). Clustered standard errors at the municipality level in parenthesis. Column (1) shows regression coefficient of the treatment for the whole sample (average effect). Columns (2) to (7) show coefficients of the treatment in the regression for each sub-sample. 
Table 28: Heterogeneous effects: First follow-up Tablet effect on Financial Attitudes

\begin{tabular}{|c|c|c|c|c|c|c|c|c|c|}
\hline & \multirow[b]{2}{*}{$\begin{array}{l}\text { Total } \\
(1)\end{array}$} & \multicolumn{4}{|c|}{ Interactions with SISBEN points quartiles } & \multicolumn{4}{|c|}{ Interactions with age quartiles } \\
\hline & & $\begin{array}{l}\text { Treat } \\
(2)\end{array}$ & $\begin{array}{c}\text { Treat*Q2 } \\
\text { (3) }\end{array}$ & $\begin{array}{c}\text { Treat*Q3 } \\
\text { (4) }\end{array}$ & $\begin{array}{c}\text { Treat*Q44 } \\
\text { (5) }\end{array}$ & $\begin{array}{c}\text { Treat } \\
(6)\end{array}$ & $\begin{array}{c}\text { Treat*Q2 } \\
(7)\end{array}$ & $\begin{array}{l}\text { Treat*Q3 } \\
\text { (8) }\end{array}$ & $\begin{array}{l}\text { Treat*Q44 } \\
\text { (9) }\end{array}$ \\
\hline Has a savings goal & $\begin{array}{c}0.167^{* * * *} \\
(0.028)\end{array}$ & $\begin{array}{c}0.163^{* * *} \\
(0.045)\end{array}$ & $\begin{array}{c}0.072 \\
(0.058)\end{array}$ & $\begin{array}{c}-0.069 \\
(0.061)\end{array}$ & $\begin{array}{c}0.005 \\
(0.056)\end{array}$ & $\begin{array}{c}0.159^{* * *} \\
(0.052)\end{array}$ & $\begin{array}{c}-0.001 \\
(0.071)\end{array}$ & $\begin{array}{c}0.069 \\
(0.061)\end{array}$ & $\begin{array}{c}-0.039 \\
(0.068)\end{array}$ \\
\hline Believes can leave money in MFA account & $\begin{array}{c}0.121^{* * *} \\
(0.020)\end{array}$ & $\begin{array}{c}0.164^{* * *} \\
(0.042)\end{array}$ & $\begin{array}{c}-0.089 \\
(0.064)\end{array}$ & $\begin{array}{c}-0.036 \\
(0.054)\end{array}$ & $\begin{array}{c}-0.049 \\
(0.054)\end{array}$ & $\begin{array}{c}0.100^{* * *} \\
(0.037)\end{array}$ & $\begin{array}{c}0.082 \\
(0.053)\end{array}$ & $\begin{array}{c}-0.005 \\
(0.059)\end{array}$ & $\begin{array}{c}0.004 \\
(0.052)\end{array}$ \\
\hline Trust in bank & $\begin{array}{c}0.204^{* * *} \\
(0.046)\end{array}$ & $\begin{array}{l}0.189^{* *} \\
(0.086)\end{array}$ & $\begin{array}{c}-0.024 \\
(0.124)\end{array}$ & $\begin{array}{c}0.076 \\
(0.136)\end{array}$ & $\begin{array}{c}0.030 \\
(0.122)\end{array}$ & $\begin{array}{c}0.257 * * * \\
(0.083)\end{array}$ & $\begin{array}{c}-0.037 \\
(0.120)\end{array}$ & $\begin{array}{c}-0.054 \\
(0.114)\end{array}$ & $\begin{array}{c}-0.108 \\
(0.124)\end{array}$ \\
\hline Comfort with banks & $\begin{array}{c}0.190^{* * *} \\
(0.046)\end{array}$ & $\begin{array}{c}0.313^{* * *} \\
(0.092)\end{array}$ & $\begin{array}{c}-0.145 \\
(0.120)\end{array}$ & $\begin{array}{c}-0.200 \\
(0.145)\end{array}$ & $\begin{array}{c}-0.187^{*} \\
(0.096)\end{array}$ & $\begin{array}{c}0.289^{* * *} \\
(0.093)\end{array}$ & $\begin{array}{c}-0.142 \\
(0.117)\end{array}$ & $\begin{array}{c}-0.063 \\
(0.142)\end{array}$ & $\begin{array}{c}-0.183 \\
(0.113)\end{array}$ \\
\hline Preference: money in bank vs. cash & $\begin{array}{c}0.156^{* * *} \\
(0.038)\end{array}$ & $\begin{array}{c}0.106 \\
(0.072)\end{array}$ & $\begin{array}{c}0.082 \\
(0.102)\end{array}$ & $\begin{array}{c}0.081 \\
(0.124)\end{array}$ & $\begin{array}{c}0.080 \\
(0.105)\end{array}$ & $\begin{array}{c}0.203^{* * *} \\
(0.076)\end{array}$ & $\begin{array}{c}-0.123 \\
(0.111)\end{array}$ & $\begin{array}{c}-0.079 \\
(0.105)\end{array}$ & $\begin{array}{c}0.016 \\
(0.103)\end{array}$ \\
\hline
\end{tabular}

Intertemporal preference: today vs. one month

Notes: *** significant at $1 \%, * *$ significant at $5 \%, *$ significant at $10 \%$ (based on $p$-values unadjusted for multiple-hypothesis testing). Clustered standard errors at the municipality level in parenthesis. Column (1) shows regression coefficient of the treatment for the whole sample (average effect). Columns (2) to (5) and (6) to (9) show coefficients of the regression that includes interaction terms of the treatment variable with SISBEN points and age, respectively. 
Table 29: Heterogeneous effects: Second follow-up Tablet effect on Financial Attitudes

\begin{tabular}{|c|c|c|c|c|c|c|c|}
\hline & \multirow[b]{2}{*}{$\begin{array}{c}\text { Total } \\
(1)\end{array}$} & \multicolumn{2}{|c|}{ Area } & \multicolumn{2}{|c|}{ Region } & \multicolumn{2}{|c|}{ Schooling } \\
\hline & & $\begin{array}{l}\text { Urban } \\
(2)\end{array}$ & $\begin{array}{c}\text { Rural } \\
(3)\end{array}$ & $\begin{array}{c}\text { Caribe } \\
(4)\end{array}$ & $\begin{array}{c}\text { Pacifico } \\
\text { (5) }\end{array}$ & $\begin{array}{c}\text { Primary } \\
\text { (6) }\end{array}$ & $\begin{array}{c}\text { Secondary } \\
(7)\end{array}$ \\
\hline Has a savings goal & $\begin{array}{c}0.093^{* * *} \\
(0.025)\end{array}$ & $\begin{array}{l}0.081^{* *} \\
(0.037)\end{array}$ & $\begin{array}{c}0.089^{* * *} \\
(0.028)\end{array}$ & $\begin{array}{c}0.097^{* * *} * \\
(0.032)\end{array}$ & $\begin{array}{l}0.077^{* *} \\
(0.034)\end{array}$ & $\begin{array}{c}0.110^{* * *} \\
(0.031)\end{array}$ & $\begin{array}{l}0.080^{* *} \\
(0.032)\end{array}$ \\
\hline Believes can leave money in MFA account & $\begin{array}{c}0.073^{* * *} \\
(0.023)\end{array}$ & $\begin{array}{c}0.088^{* * *} \\
(0.033)\end{array}$ & $\begin{array}{c}0.060^{*} \\
(0.033)\end{array}$ & $\begin{array}{l}0.052^{* *} \\
(0.025)\end{array}$ & $\begin{array}{c}0.109 * * \\
(0.049)\end{array}$ & $\begin{array}{c}0.047 \\
(0.034)\end{array}$ & $\begin{array}{c}0.097^{* * *} \\
(0.026)\end{array}$ \\
\hline Trust in bank & $\begin{array}{c}0.203^{* * *} \\
(0.048)\end{array}$ & $\begin{array}{c}0.222^{* * *} \\
(0.056)\end{array}$ & $\begin{array}{l}0.198^{* *} \\
(0.076)\end{array}$ & $\begin{array}{c}0.253^{* * *} \\
(0.056)\end{array}$ & $\begin{array}{c}0.042 \\
(0.077)\end{array}$ & $\begin{array}{l}0.137^{* *} \\
(0.068)\end{array}$ & $\begin{array}{c}0.244^{* * *} \\
(0.061)\end{array}$ \\
\hline Comfort with banks & $\begin{array}{c}0.023 \\
(0.052)\end{array}$ & $\begin{array}{c}0.082 \\
(0.079)\end{array}$ & $\begin{array}{c}-0.047 \\
(0.064)\end{array}$ & $\begin{array}{c}0.035 \\
(0.068)\end{array}$ & $\begin{array}{c}-0.029 \\
(0.079)\end{array}$ & $\begin{array}{c}-0.077 \\
(0.074)\end{array}$ & $\begin{array}{c}0.100 \\
(0.071)\end{array}$ \\
\hline Preference: money in bank vs. cash & $\begin{array}{c}0.179^{* * *} \\
(0.045)\end{array}$ & $\begin{array}{c}0.187^{* * *} \\
(0.057)\end{array}$ & $\begin{array}{c}0.187^{* * *} \\
(0.057)\end{array}$ & $\begin{array}{c}0.183^{* * *} \\
(0.052)\end{array}$ & $\begin{array}{c}0.163 \\
(0.097)\end{array}$ & $\begin{array}{c}0.215^{* * *} \\
(0.067)\end{array}$ & $\begin{array}{l}0.147^{* *} \\
(0.057)\end{array}$ \\
\hline Intertemporal preference: today vs. one month & $\begin{array}{c}-0.167^{* * *} \\
(0.045)\end{array}$ & $\begin{array}{c}-0.199^{* * *} \\
(0.062)\end{array}$ & $\begin{array}{c}-0.148^{* *} \\
(0.061)\end{array}$ & $\begin{array}{c}-0.124^{* *} \\
(0.050)\end{array}$ & $\begin{array}{c}-0.232^{* *} \\
(0.088)\end{array}$ & $\begin{array}{c}-0.150^{* *} \\
(0.062)\end{array}$ & $\begin{array}{c}-0.166^{* * * *} \\
(0.057)\end{array}$ \\
\hline
\end{tabular}

Notes: *** significant at $1 \%, * *$ significant at $5 \%, *$ significant at $10 \%$ (based on $p$-values unadjusted for multiple-hypothesis testing). Clustered standard errors at the municipality level in parenthesis. Column (1) shows regression coefficient of the treatment for the whole sample (average effect). Columns (2) to (7) show coefficients of the treatment in the regression for each sub-sample. 
Table 30: Heterogeneous effects: Second follow-up Tablet effect on Financial Attitudes

\begin{tabular}{|c|c|c|c|c|c|c|c|c|c|}
\hline & \multirow[b]{2}{*}{$\begin{array}{c}\text { Total } \\
(1)\end{array}$} & \multicolumn{4}{|c|}{ Interactions with SISBEN points quartiles } & \multicolumn{4}{|c|}{ Interactions with age quartiles } \\
\hline & & $\begin{array}{l}\text { Treat } \\
(2)\end{array}$ & $\begin{array}{c}\text { Treat*Q2 } \\
\text { (3) }\end{array}$ & $\begin{array}{c}\text { Treat*Q3 } \\
\text { (4) }\end{array}$ & $\begin{array}{c}\text { Treat*Q44 } \\
\text { (5) }\end{array}$ & $\begin{array}{l}\text { Treat } \\
(6)\end{array}$ & $\begin{array}{c}\text { Treat*Q2 } \\
\text { (7) }\end{array}$ & $\begin{array}{c}\text { Treat*Q3 } \\
\text { (8) }\end{array}$ & $\begin{array}{c}\text { Treat*Q44 } \\
\text { (9) }\end{array}$ \\
\hline Has a savings goal & $\begin{array}{c}0.093^{* * *} \\
(0.025)\end{array}$ & $\begin{array}{c}0.071^{*} \\
(0.039)\end{array}$ & $\begin{array}{c}0.096^{*} \\
(0.055)\end{array}$ & $\begin{array}{c}-0.035 \\
(0.053)\end{array}$ & $\begin{array}{c}0.008 \\
(0.064)\end{array}$ & $\begin{array}{c}0.045 \\
(0.046)\end{array}$ & $\begin{array}{c}0.068 \\
(0.056)\end{array}$ & $\begin{array}{c}0.097 \\
(0.059)\end{array}$ & $\begin{array}{c}0.032 \\
(0.066)\end{array}$ \\
\hline Believes can leave money in MFA account & $\begin{array}{c}0.073^{* * *} \\
(0.023)\end{array}$ & $\begin{array}{c}0.058 \\
(0.041)\end{array}$ & $\begin{array}{c}0.030 \\
(0.057)\end{array}$ & $\begin{array}{c}-0.004 \\
(0.061)\end{array}$ & $\begin{array}{c}0.049 \\
(0.059)\end{array}$ & $\begin{array}{c}-0.003 \\
(0.043)\end{array}$ & $\begin{array}{c}0.107^{*} \\
(0.062)\end{array}$ & $\begin{array}{l}0.166^{* *} \\
(0.063)\end{array}$ & $\begin{array}{c}0.028 \\
(0.065)\end{array}$ \\
\hline Trust in bank & $\begin{array}{c}0.203^{* * *} \\
(0.048)\end{array}$ & $\begin{array}{c}0.294^{* * *} \\
(0.089)\end{array}$ & $\begin{array}{c}-0.176 \\
(0.135)\end{array}$ & $\begin{array}{c}-0.075 \\
(0.141)\end{array}$ & $\begin{array}{c}-0.114 \\
(0.131)\end{array}$ & $\begin{array}{c}0.395^{* * *} \\
(0.102)\end{array}$ & $\begin{array}{c}-0.374^{* *} \\
(0.147)\end{array}$ & $\begin{array}{c}-0.224 \\
(0.142)\end{array}$ & $\begin{array}{c}-0.149 \\
(0.121)\end{array}$ \\
\hline Comfort with banks & $\begin{array}{c}0.023 \\
(0.052)\end{array}$ & $\begin{array}{c}0.154^{*} \\
(0.090)\end{array}$ & $\begin{array}{c}-0.347^{* * *} \\
(0.128)\end{array}$ & $\begin{array}{c}-0.041 \\
(0.123)\end{array}$ & $\begin{array}{c}-0.179 \\
(0.137)\end{array}$ & $\begin{array}{c}0.030 \\
(0.092)\end{array}$ & $\begin{array}{c}0.063 \\
(0.138)\end{array}$ & $\begin{array}{c}-0.069 \\
(0.134)\end{array}$ & $\begin{array}{c}-0.026 \\
(0.142)\end{array}$ \\
\hline Preference: money in bank vs. cash & $\begin{array}{c}0.179^{* * *} \\
(0.045)\end{array}$ & $\begin{array}{c}0.278^{* * *} \\
(0.086)\end{array}$ & $\begin{array}{l}-0.197^{*} \\
(0.109)\end{array}$ & $\begin{array}{c}-0.108 \\
(0.136)\end{array}$ & $\begin{array}{c}-0.066 \\
(0.124)\end{array}$ & $\begin{array}{c}0.352^{* * *} \\
(0.100)\end{array}$ & $\begin{array}{c}-0.317^{* *} \\
(0.141)\end{array}$ & $\begin{array}{c}-0.160 \\
(0.127)\end{array}$ & $\begin{array}{c}-0.206 \\
(0.130)\end{array}$ \\
\hline Intertemporal preference: today vs. one month & $\begin{array}{c}-0.167^{* * *} \\
(0.045)\end{array}$ & $\begin{array}{c}-0.258^{* *} \\
(0.113)\end{array}$ & $\begin{array}{c}0.250^{*} \\
(0.135)\end{array}$ & $\begin{array}{c}0.030 \\
(0.155)\end{array}$ & $\begin{array}{c}0.066 \\
(0.148)\end{array}$ & $\begin{array}{c}-0.207^{*} \\
(0.110)\end{array}$ & $\begin{array}{c}-0.040 \\
(0.152)\end{array}$ & $\begin{array}{c}0.114 \\
(0.153)\end{array}$ & $\begin{array}{c}0.086 \\
(0.148)\end{array}$ \\
\hline
\end{tabular}

Notes: $* * *$ significant at $1 \%, * *$ significant at $5 \%, *$ significant at $10 \%$ (based on $p$-values unadjusted for multiple-hypothesis testing). Clustered standard errors at the municipality level in parenthesis. Column (1) shows regression coefficient of the treatment for the whole sample (average effect). Columns (2) to (5) and (6) to (9) show coefficients of the regression that includes interaction terms of the treatment variable with SISBEN points and age, respectively. 
Table 31: Heterogeneous effects: Third follow-up Tablet effect on Financial Attitudes

\begin{tabular}{|c|c|c|c|c|c|c|c|}
\hline & \multirow[b]{2}{*}{$\begin{array}{c}\text { Total } \\
(1)\end{array}$} & \multicolumn{2}{|c|}{ Area } & \multicolumn{2}{|c|}{ Region } & \multicolumn{2}{|c|}{ Schooling } \\
\hline & & $\begin{array}{l}\text { Urban } \\
(2)\end{array}$ & $\begin{array}{c}\text { Rural } \\
(3)\end{array}$ & $\begin{array}{c}\text { Caribe } \\
(4)\end{array}$ & $\begin{array}{c}\text { Pacifico } \\
(5)\end{array}$ & $\begin{array}{c}\text { Primary } \\
(6)\end{array}$ & $\begin{array}{c}\text { Secondary } \\
(7)\end{array}$ \\
\hline Has a savings goal & $\begin{array}{c}0.147^{* * *} \\
(0.026)\end{array}$ & $\begin{array}{c}0.153^{* * *} \\
(0.032)\end{array}$ & $\begin{array}{c}0.151^{* * *} \\
(0.033)\end{array}$ & $\begin{array}{c}0.157^{* * *} \\
(0.031)\end{array}$ & $\begin{array}{c}0.098^{*} \\
(0.047)\end{array}$ & $\begin{array}{c}0.126^{* * *} \\
(0.037)\end{array}$ & $\begin{array}{c}0.152^{* * *} \\
(0.034)\end{array}$ \\
\hline Believes can leave money in MFA account & $\begin{array}{c}0.054^{*} \\
(0.027)\end{array}$ & $\begin{array}{c}0.054^{*} \\
(0.029)\end{array}$ & $\begin{array}{c}0.057 \\
(0.037)\end{array}$ & $\begin{array}{c}0.022 \\
(0.027)\end{array}$ & $\begin{array}{c}0.111 \\
(0.067)\end{array}$ & $\begin{array}{c}0.052 \\
(0.040)\end{array}$ & $\begin{array}{l}0.062^{* *} \\
(0.028)\end{array}$ \\
\hline Trust in bank & $\begin{array}{c}0.087^{*} \\
(0.046)\end{array}$ & $\begin{array}{c}0.016 \\
(0.062)\end{array}$ & $\begin{array}{c}0.139^{*} \\
(0.072)\end{array}$ & $\begin{array}{c}0.192^{* * *} \\
(0.056)\end{array}$ & $\begin{array}{c}-0.176^{* *} \\
(0.071)\end{array}$ & $\begin{array}{c}-0.007 \\
(0.073)\end{array}$ & $\begin{array}{l}0.148^{* *} \\
(0.056)\end{array}$ \\
\hline Comfort with banks & $\begin{array}{c}0.092^{*} \\
(0.053)\end{array}$ & $\begin{array}{c}-0.006 \\
(0.069)\end{array}$ & $\begin{array}{l}0.194^{* *} \\
(0.082)\end{array}$ & $\begin{array}{c}0.046 \\
(0.058)\end{array}$ & $\begin{array}{c}0.168 \\
(0.107)\end{array}$ & $\begin{array}{c}0.029 \\
(0.095)\end{array}$ & $\begin{array}{l}0.129^{* *} \\
(0.063)\end{array}$ \\
\hline Preference: money in bank vs. cash & $\begin{array}{c}0.191^{* * *} \\
(0.056)\end{array}$ & $\begin{array}{c}0.196^{* * *} \\
(0.067)\end{array}$ & $\begin{array}{c}0.228^{* * *} \\
(0.081)\end{array}$ & $\begin{array}{c}0.193^{* * *} \\
(0.061)\end{array}$ & $\begin{array}{c}0.187 \\
(0.118)\end{array}$ & $\begin{array}{c}0.354^{* * *} \\
(0.077)\end{array}$ & $\begin{array}{c}0.064 \\
(0.070)\end{array}$ \\
\hline Intertemporal preference: today vs. one month & $\begin{array}{l}-0.085^{*} \\
(0.049)\end{array}$ & $\begin{array}{c}-0.078 \\
(0.058)\end{array}$ & $\begin{array}{c}-0.085 \\
(0.071)\end{array}$ & $\begin{array}{c}-0.061 \\
(0.050)\end{array}$ & $\begin{array}{c}-0.114 \\
(0.115)\end{array}$ & $\begin{array}{c}-0.095 \\
(0.090)\end{array}$ & $\begin{array}{c}-0.071 \\
(0.060)\end{array}$ \\
\hline
\end{tabular}

Notes: *** significant at $1 \%, * *$ significant at $5 \%, *$ significant at $10 \%$ (based on $p$-values unadjusted for multiple-hypothesis testing). Clustered standard errors at the municipality level in parenthesis. Column (1) shows regression coefficient of the treatment for the whole sample (average effect). Columns (2) to (7) show coefficients of the treatment in the regression for each sub-sample. 
Table 32: Heterogeneous effects: Third follow-up Tablet effect on Financial Attitudes

\begin{tabular}{|c|c|c|c|c|c|c|c|c|c|}
\hline & \multirow[b]{2}{*}{$\begin{array}{c}\text { Total } \\
(1)\end{array}$} & \multicolumn{4}{|c|}{ Interactions with SISBEN points quartiles } & \multicolumn{4}{|c|}{ Interactions with age quartiles } \\
\hline & & $\begin{array}{l}\text { Treat } \\
(2)\end{array}$ & $\begin{array}{c}\text { Treat*Q2 } \\
\text { (3) }\end{array}$ & $\begin{array}{c}\text { Treat*Q3 } \\
\text { (4) }\end{array}$ & $\begin{array}{l}\text { Treat*Q44 } \\
\text { (5) }\end{array}$ & $\begin{array}{l}\text { Treat } \\
(6)\end{array}$ & $\begin{array}{c}\text { Treat*Q2 } \\
(7)\end{array}$ & $\begin{array}{c}\text { Treat*Q3 } \\
\text { (8) }\end{array}$ & $\begin{array}{c}\text { Treat*Q4 } \\
(9)\end{array}$ \\
\hline Has a savings goal & $\begin{array}{c}0.147^{* * *} * \\
(0.026)\end{array}$ & $\begin{array}{c}0.176^{* * *} \\
(0.045)\end{array}$ & $\begin{array}{c}-0.043 \\
(0.055)\end{array}$ & $\begin{array}{c}-0.042 \\
(0.060)\end{array}$ & $\begin{array}{c}-0.040 \\
(0.067)\end{array}$ & $\begin{array}{c}0.188^{* * *} \\
(0.048)\end{array}$ & $\begin{array}{c}-0.041 \\
(0.078)\end{array}$ & $\begin{array}{c}-0.098 \\
(0.062)\end{array}$ & $\begin{array}{c}-0.022 \\
(0.066)\end{array}$ \\
\hline Believes can leave money in MFA account & $\begin{array}{c}0.054^{*} \\
(0.027)\end{array}$ & $\begin{array}{c}0.043 \\
(0.041)\end{array}$ & $\begin{array}{c}-0.014 \\
(0.049)\end{array}$ & $\begin{array}{c}0.069 \\
(0.053)\end{array}$ & $\begin{array}{c}0.003 \\
(0.055)\end{array}$ & $\begin{array}{c}-0.001 \\
(0.041)\end{array}$ & $\begin{array}{c}0.060 \\
(0.065)\end{array}$ & $\begin{array}{c}0.047 \\
(0.065)\end{array}$ & $\begin{array}{l}0.120^{* *} \\
(0.054)\end{array}$ \\
\hline Trust in bank & $\begin{array}{c}0.087^{*} \\
(0.046)\end{array}$ & $\begin{array}{c}0.085 \\
(0.090)\end{array}$ & $\begin{array}{c}0.094 \\
(0.133)\end{array}$ & $\begin{array}{c}0.056 \\
(0.164)\end{array}$ & $\begin{array}{l}-0.111 \\
(0.137)\end{array}$ & $\begin{array}{c}0.105 \\
(0.091)\end{array}$ & $\begin{array}{l}-0.039 \\
(0.132)\end{array}$ & $\begin{array}{l}-0.079 \\
(0.127)\end{array}$ & $\begin{array}{c}0.054 \\
(0.131)\end{array}$ \\
\hline Comfort with banks & $\begin{array}{c}0.092^{*} \\
(0.053)\end{array}$ & $\begin{array}{c}0.154 \\
(0.093)\end{array}$ & $\begin{array}{c}-0.036 \\
(0.129)\end{array}$ & $\begin{array}{c}-0.044 \\
(0.138)\end{array}$ & $\begin{array}{c}-0.168 \\
(0.141)\end{array}$ & $\begin{array}{c}0.066 \\
(0.085)\end{array}$ & $\begin{array}{c}0.131 \\
(0.108)\end{array}$ & $\begin{array}{c}-0.097 \\
(0.152)\end{array}$ & $\begin{array}{c}0.084 \\
(0.135)\end{array}$ \\
\hline Preference: money in bank vs. cash & $\begin{array}{c}0.191^{* * * *} \\
(0.056)\end{array}$ & $\begin{array}{c}0.292^{* * *} \\
(0.082)\end{array}$ & $\begin{array}{c}-0.143 \\
(0.122)\end{array}$ & $\begin{array}{c}-0.093 \\
(0.137)\end{array}$ & $\begin{array}{c}-0.160 \\
(0.103)\end{array}$ & $\begin{array}{c}0.192^{*} \\
(0.101)\end{array}$ & $\begin{array}{c}-0.114 \\
(0.117)\end{array}$ & $\begin{array}{c}0.072 \\
(0.136)\end{array}$ & $\begin{array}{c}0.050 \\
(0.128)\end{array}$ \\
\hline Intertemporal preference: today vs. one month & $\begin{array}{c}-0.085^{*} \\
(0.049)\end{array}$ & $\begin{array}{l}-0.175^{*} \\
(0.095)\end{array}$ & $\begin{array}{c}0.234^{*} \\
(0.121)\end{array}$ & $\begin{array}{c}0.106 \\
(0.154)\end{array}$ & $\begin{array}{c}-0.008 \\
(0.116)\end{array}$ & $\begin{array}{c}-0.217^{* *} \\
(0.100)\end{array}$ & $\begin{array}{c}0.326^{* *} \\
(0.132)\end{array}$ & $\begin{array}{c}0.046 \\
(0.142)\end{array}$ & $\begin{array}{c}0.150 \\
(0.154)\end{array}$ \\
\hline
\end{tabular}

Notes: $* * *$ significant at $1 \%, * *$ significant at $5 \%, *$ significant at $10 \%$ (based on $p$-values unadjusted for multiple-hypothesis testing). Clustered standard errors at the municipality level in parenthesis. Column (1) shows regression coefficient of the treatment for the whole sample (average effect). Columns (2) to (5) and (6) to (9) show coefficients of the regression that includes interaction terms of the treatment variable with SISBEN points and age, respectively. 
Table 33: Heterogeneous effects: First follow-up Tablet effect on Financial Practices (ATM, MFA)

\begin{tabular}{lcccccccc}
\hline & \multicolumn{4}{c}{ Area } & \multicolumn{2}{c}{ Region } & \multicolumn{2}{c}{ Schooling } \\
& Total & Urban & Rural & Caribe & Pacifico & Primary & Secondary \\
$(1)$ & $(2)$ & $(3)$ & $(4)$ & $(5)$ & $(6)$ & $(7)$ \\
\hline Manages household finances & $0.016^{*}$ & 0.011 & $0.024^{*}$ & $0.019^{*}$ & 0.015 & 0.010 & $0.021^{*}$ \\
& $(0.009)$ & $(0.013)$ & $(0.013)$ & $(0.011)$ & $(0.013)$ & $(0.010)$ & $(0.012)$ \\
& 0.032 & 0.027 & 0.029 & $0.066^{* * *}$ & -0.046 & -0.001 & $0.071^{* *}$ \\
Keeps written track of accounts & $(0.020)$ & $(0.030)$ & $(0.026)$ & $(0.024)$ & $(0.032)$ & $(0.032)$ & $(0.028)$ \\
Withdrew last MFA transfer & -0.007 & -0.023 & 0.012 & -0.011 & 0.004 & $-0.038^{* *}$ & 0.020 \\
& $(0.011)$ & $(0.016)$ & $(0.021)$ & $(0.014)$ & $(0.021)$ & $(0.017)$ & $(0.015)$ \\
Accompanied when withdrew & $0.062^{* * *}$ & $0.073^{* *}$ & 0.056 & $0.055^{* *}$ & $0.078^{*}$ & $0.069^{* *}$ & $0.063^{* *}$ \\
& $(0.021)$ & $(0.030)$ & $(0.036)$ & $(0.025)$ & $(0.045)$ & $(0.027)$ & $(0.027)$
\end{tabular}

Has money in MFA account (today)

Leaves money in MFA account

Someone helped use ATM

Feels can teach ATM use

Has taught someone use ATM

Has an MFA card

Notes: *** significant at $1 \%, * *$ significant at $5 \%, *$ significant at $10 \%$ (based on $p$-values unadjusted for multiple-hypothesis testing). Clustered standard errors at the municipality level in parenthesis. Column (1) shows regression coefficient of the treatment for the whole sample (average effect). Columns (2) to (7) show coefficients of the treatment in the regression for each sub-sample. 
Table 34: Heterogeneous effects: First follow-up Tablet effect on Financial Practices (ATM, MFA)

\begin{tabular}{|c|c|c|c|c|c|c|c|c|c|}
\hline & \multirow[b]{2}{*}{$\begin{array}{c}\text { Total } \\
(1)\end{array}$} & \multicolumn{4}{|c|}{ Interactions with SISBEN points quartiles } & \multicolumn{4}{|c|}{ Interactions with age quartiles } \\
\hline & & $\begin{array}{l}\text { Treat } \\
(2)\end{array}$ & $\begin{array}{c}\text { Treat*Q2 } \\
(3)\end{array}$ & $\begin{array}{c}\text { Treat*Q3 } \\
(4)\end{array}$ & $\begin{array}{c}\text { Treat*Q4 } \\
(5)\end{array}$ & $\begin{array}{c}\text { Treat } \\
(6)\end{array}$ & $\begin{array}{c}\text { Treat*Q2 } \\
(7)\end{array}$ & $\begin{array}{c}\text { Treat*Q3 } \\
(8)\end{array}$ & $\begin{array}{c}\text { Treat*Q4 } \\
(9)\end{array}$ \\
\hline Manages household finances & $\begin{array}{c}0.016^{*} \\
(0.009)\end{array}$ & $\begin{array}{c}-0.001 \\
(0.014)\end{array}$ & $\begin{array}{c}0.027 \\
(0.019)\end{array}$ & $\begin{array}{c}0.033 \\
(0.022)\end{array}$ & $\begin{array}{c}0.014 \\
(0.023)\end{array}$ & $\begin{array}{c}0.014 \\
(0.021)\end{array}$ & $\begin{array}{c}0.008 \\
(0.024)\end{array}$ & $\begin{array}{c}-0.002 \\
(0.026)\end{array}$ & $\begin{array}{c}0.004 \\
(0.026)\end{array}$ \\
\hline Keeps written track of accounts & $\begin{array}{c}0.032 \\
(0.020)\end{array}$ & $\begin{array}{c}-0.014 \\
(0.037)\end{array}$ & $\begin{array}{c}0.042 \\
(0.063)\end{array}$ & $\begin{array}{c}0.137^{* *} \\
(0.052)\end{array}$ & $\begin{array}{c}0.012 \\
(0.059)\end{array}$ & $\begin{array}{c}0.013 \\
(0.039)\end{array}$ & $\begin{array}{c}0.086 \\
(0.059)\end{array}$ & $\begin{array}{c}-0.023 \\
(0.051)\end{array}$ & $\begin{array}{c}0.012 \\
(0.050)\end{array}$ \\
\hline Withdrew last MFA transfer & $\begin{array}{l}-0.007 \\
(0.011)\end{array}$ & $\begin{array}{c}0.011 \\
(0.024)\end{array}$ & $\begin{array}{c}-0.001 \\
(0.041)\end{array}$ & $\begin{array}{c}-0.064^{*} \\
(0.038)\end{array}$ & $\begin{array}{c}-0.014 \\
(0.035)\end{array}$ & $\begin{array}{c}-0.008 \\
(0.024)\end{array}$ & $\begin{array}{c}0.030 \\
(0.028)\end{array}$ & $\begin{array}{c}-0.017 \\
(0.034)\end{array}$ & $\begin{array}{l}-0.010 \\
(0.044)\end{array}$ \\
\hline Accompanied when withdrew & $\begin{array}{c}0.062^{* * *} \\
(0.021)\end{array}$ & $\begin{array}{c}0.031 \\
(0.042)\end{array}$ & $\begin{array}{c}0.046 \\
(0.062)\end{array}$ & $\begin{array}{c}0.107^{*} \\
(0.063)\end{array}$ & $\begin{array}{l}-0.010 \\
(0.054)\end{array}$ & $\begin{array}{c}0.026 \\
(0.033)\end{array}$ & $\begin{array}{c}0.064 \\
(0.057)\end{array}$ & $\begin{array}{c}0.050 \\
(0.049)\end{array}$ & $\begin{array}{c}0.017 \\
(0.055)\end{array}$ \\
\hline
\end{tabular}

Has money in MFA account (today)

Leaves money in MFA account

Someone helped use ATM

Feels can teach ATM use

Has taught someone use ATM

Has an MFA card

Notes: *** significant at $1 \%, * *$ significant at $5 \%, *$ significant at $10 \%$ (based on $p$-values unadjusted for multiple-hypothesis testing). Clustered standard errors at the municipality level in parenthesis. Column (1) shows regression coefficient of the treatment for the whole sample (average effect). Columns (2) to (5) and (6) to (9) show coefficients of the regression that includes interaction terms of the treatment variable with SISBEN points and age, respectively. 
Table 35: Heterogeneous effects: Second follow-up Tablet effect on Financial Practices (ATM, MFA)

\begin{tabular}{|c|c|c|c|c|c|c|c|}
\hline & \multirow[b]{2}{*}{$\begin{array}{c}\text { Total } \\
(1)\end{array}$} & \multicolumn{2}{|c|}{ Area } & \multicolumn{2}{|c|}{ Region } & \multicolumn{2}{|c|}{ Schooling } \\
\hline & & $\begin{array}{l}\text { Urban } \\
\quad(2)\end{array}$ & $\begin{array}{c}\text { Rural } \\
(3)\end{array}$ & $\begin{array}{c}\text { Caribe } \\
(4)\end{array}$ & $\begin{array}{c}\text { Pacifico } \\
\quad(5)\end{array}$ & $\begin{array}{l}\text { Primary } \\
(6)\end{array}$ & $\begin{array}{c}\text { Secondary } \\
(7)\end{array}$ \\
\hline Manages household finances & $\begin{array}{l}0.018^{*} \\
(0.010)\end{array}$ & $\begin{array}{c}-0.002 \\
(0.012)\end{array}$ & $\begin{array}{c}0.038^{* *} \\
(0.015)\end{array}$ & $\begin{array}{c}0.014 \\
(0.012)\end{array}$ & $\begin{array}{c}0.031 \\
(0.019)\end{array}$ & $\begin{array}{l}0.028^{*} \\
(0.014)\end{array}$ & $\begin{array}{c}0.010 \\
(0.014)\end{array}$ \\
\hline Keeps written track of accounts & $\begin{array}{c}0.012 \\
(0.017)\end{array}$ & $\begin{array}{c}0.003 \\
(0.028)\end{array}$ & $\begin{array}{c}0.011 \\
(0.020)\end{array}$ & $\begin{array}{c}0.018 \\
(0.023)\end{array}$ & $\begin{array}{c}0.004 \\
(0.018)\end{array}$ & $\begin{array}{l}-0.017 \\
(0.021)\end{array}$ & $\begin{array}{c}0.035 \\
(0.027)\end{array}$ \\
\hline Withdrew last MFA transfer & $\begin{array}{c}0.009 \\
(0.016)\end{array}$ & $\begin{array}{l}-0.018 \\
(0.020)\end{array}$ & $\begin{array}{c}0.050 \\
(0.033)\end{array}$ & $\begin{array}{l}-0.001 \\
(0.015)\end{array}$ & $\begin{array}{c}0.034 \\
(0.040)\end{array}$ & $\begin{array}{c}-0.002 \\
(0.030)\end{array}$ & $\begin{array}{c}0.020 \\
(0.018)\end{array}$ \\
\hline Accompanied when withdrew & $\begin{array}{c}0.044 \\
(0.028)\end{array}$ & $\begin{array}{c}0.051 \\
(0.044)\end{array}$ & $\begin{array}{l}0.069^{*} \\
(0.040)\end{array}$ & $\begin{array}{c}0.008 \\
(0.036)\end{array}$ & $\begin{array}{l}0.088^{*} \\
(0.044)\end{array}$ & $\begin{array}{c}0.087^{* *} \\
(0.039)\end{array}$ & $\begin{array}{c}0.010 \\
(0.044)\end{array}$ \\
\hline Has money in MFA account (today) & $\begin{array}{c}0.062^{*} \\
(0.034)\end{array}$ & $\begin{array}{c}0.073 \\
(0.044)\end{array}$ & $\begin{array}{c}0.052 \\
(0.046)\end{array}$ & $\begin{array}{l}0.079^{*} \\
(0.042)\end{array}$ & $\begin{array}{c}0.002 \\
(0.064)\end{array}$ & $\begin{array}{c}0.052 \\
(0.044)\end{array}$ & $\begin{array}{c}0.077^{* *} \\
(0.038)\end{array}$ \\
\hline Leaves money in MFA account & $\begin{array}{c}0.066^{* *} \\
(0.026)\end{array}$ & $\begin{array}{c}0.101^{* * *} \\
(0.038)\end{array}$ & $\begin{array}{c}0.044 \\
(0.044)\end{array}$ & $\begin{array}{c}0.070^{* *} \\
(0.027)\end{array}$ & $\begin{array}{c}0.054 \\
(0.070)\end{array}$ & $\begin{array}{c}0.072^{* *} \\
(0.034)\end{array}$ & $\begin{array}{c}0.071^{* *} \\
(0.032)\end{array}$ \\
\hline Someone helped use ATM & $\begin{array}{c}0.004 \\
(0.039)\end{array}$ & $\begin{array}{c}0.064 \\
(0.066)\end{array}$ & $\begin{array}{c}-0.079 \\
(0.054)\end{array}$ & $\begin{array}{c}-0.039 \\
(0.053)\end{array}$ & $\begin{array}{c}0.026 \\
(0.058)\end{array}$ & $\begin{array}{c}0.041 \\
(0.056)\end{array}$ & $\begin{array}{c}-0.015 \\
(0.063)\end{array}$ \\
\hline Feels can teach ATM use & $\begin{array}{c}0.056^{* * *} \\
(0.020)\end{array}$ & $\begin{array}{l}-0.005 \\
(0.035)\end{array}$ & $\begin{array}{c}0.115^{* * *} \\
(0.024)\end{array}$ & $\begin{array}{c}0.062^{* *} \\
(0.026)\end{array}$ & $\begin{array}{c}0.038 \\
(0.028)\end{array}$ & $\begin{array}{c}0.035 \\
(0.027)\end{array}$ & $\begin{array}{c}0.086^{* *} \\
(0.033)\end{array}$ \\
\hline Has taught someone use ATM & $\begin{array}{c}0.046^{* *} \\
(0.022)\end{array}$ & $\begin{array}{c}0.018 \\
(0.035)\end{array}$ & $\begin{array}{c}0.069^{* * *} \\
(0.024)\end{array}$ & $\begin{array}{c}0.036 \\
(0.029)\end{array}$ & $\begin{array}{c}0.065^{*} \\
(0.033)\end{array}$ & $\begin{array}{c}0.029 \\
(0.020)\end{array}$ & $\begin{array}{l}0.070^{*} \\
(0.037)\end{array}$ \\
\hline Has an MFA card & $\begin{array}{c}0.015 \\
(0.023)\end{array}$ & $\begin{array}{l}-0.015 \\
(0.030)\end{array}$ & $\begin{array}{c}0.026 \\
(0.025)\end{array}$ & $\begin{array}{c}0.011 \\
(0.025)\end{array}$ & $\begin{array}{l}-0.002 \\
(0.025)\end{array}$ & $\begin{array}{c}0.012 \\
(0.031)\end{array}$ & $\begin{array}{c}0.017 \\
(0.022)\end{array}$ \\
\hline
\end{tabular}

Notes: $* * *$ significant at $1 \%, * *$ significant at $5 \%, *$ significant at $10 \%$ (based on $p$-values unadjusted for multiple-hypothesis testing). Clustered standard errors at the municipality level in parenthesis. Column (1) shows regression coefficient of the treatment for the whole sample (average effect). Columns (2) to (7) show coefficients of the treatment in the regression for each sub-sample. 
Table 36: Heterogeneous effects: Second follow-up Tablet effect on Financial Practices (ATM, MFA)

\begin{tabular}{|c|c|c|c|c|c|c|c|c|c|}
\hline & \multirow[b]{2}{*}{$\begin{array}{c}\text { Total } \\
(1)\end{array}$} & \multicolumn{4}{|c|}{ Interactions with SISBEN points quartiles } & \multicolumn{4}{|c|}{ Interactions with age quartiles } \\
\hline & & $\begin{array}{c}\text { Treat } \\
(2)\end{array}$ & $\begin{array}{c}\text { Treat*Q2 } \\
(3)\end{array}$ & $\begin{array}{c}\text { Treat* }{ }^{*} 3 \\
(4)\end{array}$ & $\begin{array}{c}\text { Treat*Q44 } \\
(5)\end{array}$ & $\begin{array}{c}\text { Treat } \\
(6)\end{array}$ & $\begin{array}{c}\text { Treat* }{ }^{*} 2 \\
(7)\end{array}$ & $\begin{array}{c}\text { Treat*Q3 } \\
(8)\end{array}$ & $\begin{array}{c}\text { Treat*Q4 } \\
(9)\end{array}$ \\
\hline Manages household finances & $\begin{array}{c}0.018^{*} \\
(0.010)\end{array}$ & $\begin{array}{c}0.016 \\
(0.018)\end{array}$ & $\begin{array}{l}-0.025 \\
(0.027)\end{array}$ & $\begin{array}{c}0.016 \\
(0.027)\end{array}$ & $\begin{array}{c}0.019 \\
(0.026)\end{array}$ & $\begin{array}{c}0.014 \\
(0.028)\end{array}$ & $\begin{array}{c}0.014 \\
(0.030)\end{array}$ & $\begin{array}{c}-0.002 \\
(0.036)\end{array}$ & $\begin{array}{c}0.003 \\
(0.032)\end{array}$ \\
\hline Keeps written track of accounts & $\begin{array}{c}0.012 \\
(0.017)\end{array}$ & $\begin{array}{c}0.023 \\
(0.033)\end{array}$ & $\begin{array}{c}-0.031 \\
(0.047)\end{array}$ & $\begin{array}{c}0.023 \\
(0.059)\end{array}$ & $\begin{array}{l}-0.042 \\
(0.055)\end{array}$ & $\begin{array}{c}0.005 \\
(0.039)\end{array}$ & $\begin{array}{c}0.057 \\
(0.057)\end{array}$ & $\begin{array}{l}-0.051 \\
(0.054)\end{array}$ & $\begin{array}{c}0.019 \\
(0.045)\end{array}$ \\
\hline Withdrew last MFA transfer & $\begin{array}{c}0.009 \\
(0.016)\end{array}$ & $\begin{array}{c}0.071^{*} \\
(0.036)\end{array}$ & $\begin{array}{l}-0.085 \\
(0.052)\end{array}$ & $\begin{array}{c}-0.106^{*} \\
(0.058)\end{array}$ & $\begin{array}{c}-0.084^{*} \\
(0.047)\end{array}$ & $\begin{array}{c}0.060^{* *} \\
(0.026)\end{array}$ & $\begin{array}{c}-0.057 \\
(0.037)\end{array}$ & $\begin{array}{c}-0.047 \\
(0.044)\end{array}$ & $\begin{array}{c}-0.099 * * * \\
(0.037)\end{array}$ \\
\hline Accompanied when withdrew & $\begin{array}{c}0.044 \\
(0.028)\end{array}$ & $\begin{array}{c}0.055 \\
(0.058)\end{array}$ & $\begin{array}{c}0.094 \\
(0.084)\end{array}$ & $\begin{array}{c}0.033 \\
(0.076)\end{array}$ & $\begin{array}{c}-0.172^{*} \\
(0.091)\end{array}$ & $\begin{array}{l}-0.019 \\
(0.060)\end{array}$ & $\begin{array}{c}0.032 \\
(0.076)\end{array}$ & $\begin{array}{c}0.180^{* *} \\
(0.079)\end{array}$ & $\begin{array}{c}0.034 \\
(0.082)\end{array}$ \\
\hline Has money in MFA account (today) & $\begin{array}{l}0.062^{*} \\
(0.034)\end{array}$ & $\begin{array}{c}0.022 \\
(0.059)\end{array}$ & $\begin{array}{c}0.014 \\
(0.081)\end{array}$ & $\begin{array}{c}0.094 \\
(0.081)\end{array}$ & $\begin{array}{c}0.077 \\
(0.079)\end{array}$ & $\begin{array}{c}0.034 \\
(0.056)\end{array}$ & $\begin{array}{l}-0.041 \\
(0.069)\end{array}$ & $\begin{array}{c}0.073 \\
(0.070)\end{array}$ & $\begin{array}{c}0.085 \\
(0.077)\end{array}$ \\
\hline Leaves money in MFA account & $\begin{array}{c}0.066^{* *} \\
(0.026)\end{array}$ & $\begin{array}{c}0.062 \\
(0.048)\end{array}$ & $\begin{array}{c}0.019 \\
(0.077)\end{array}$ & $\begin{array}{c}0.008 \\
(0.071)\end{array}$ & $\begin{array}{c}-0.007 \\
(0.080)\end{array}$ & $\begin{array}{c}0.039 \\
(0.055)\end{array}$ & $\begin{array}{c}0.018 \\
(0.078)\end{array}$ & $\begin{array}{c}0.086 \\
(0.070)\end{array}$ & $\begin{array}{c}-0.008 \\
(0.083)\end{array}$ \\
\hline Someone helped use ATM & $\begin{array}{c}0.004 \\
(0.039)\end{array}$ & $\begin{array}{c}0.039 \\
(0.067)\end{array}$ & $\begin{array}{l}-0.070 \\
(0.093)\end{array}$ & $\begin{array}{c}0.062 \\
(0.110)\end{array}$ & $\begin{array}{l}-0.137 \\
(0.122)\end{array}$ & $\begin{array}{c}0.004 \\
(0.092)\end{array}$ & $\begin{array}{c}-0.079 \\
(0.142)\end{array}$ & $\begin{array}{c}0.091 \\
(0.110)\end{array}$ & $\begin{array}{c}-0.033 \\
(0.119)\end{array}$ \\
\hline Feels can teach ATM use & $\begin{array}{c}0.056^{* * *} \\
(0.020)\end{array}$ & $\begin{array}{c}0.056 \\
(0.041)\end{array}$ & $\begin{array}{c}0.056 \\
(0.067)\end{array}$ & $\begin{array}{c}-0.077 \\
(0.065)\end{array}$ & $\begin{array}{c}0.020 \\
(0.072)\end{array}$ & $\begin{array}{c}0.105^{* *} \\
(0.047)\end{array}$ & $\begin{array}{c}-0.016 \\
(0.060)\end{array}$ & $\begin{array}{c}-0.037 \\
(0.060)\end{array}$ & $\begin{array}{c}-0.143^{* *} \\
(0.064)\end{array}$ \\
\hline Has taught someone use ATM & $\begin{array}{c}0.046^{* *} \\
(0.022)\end{array}$ & $\begin{array}{c}0.078^{*} \\
(0.040)\end{array}$ & $\begin{array}{c}-0.039 \\
(0.059)\end{array}$ & $\begin{array}{c}-0.107 \\
(0.071)\end{array}$ & $\begin{array}{c}0.013 \\
(0.060)\end{array}$ & $\begin{array}{c}0.029 \\
(0.059)\end{array}$ & $\begin{array}{c}0.087 \\
(0.071)\end{array}$ & $\begin{array}{l}-0.011 \\
(0.065)\end{array}$ & $\begin{array}{l}-0.017 \\
(0.070)\end{array}$ \\
\hline Has an MFA card & $\begin{array}{c}0.015 \\
(0.023)\end{array}$ & $\begin{array}{c}0.051 \\
(0.037)\end{array}$ & $\begin{array}{c}-0.020 \\
(0.041)\end{array}$ & $\begin{array}{c}-0.089^{*} \\
(0.052)\end{array}$ & $\begin{array}{l}-0.062 \\
(0.048)\end{array}$ & $\begin{array}{c}0.027 \\
(0.030)\end{array}$ & $\begin{array}{l}-0.026 \\
(0.035)\end{array}$ & $\begin{array}{l}-0.005 \\
(0.033)\end{array}$ & $\begin{array}{l}-0.019 \\
(0.041)\end{array}$ \\
\hline
\end{tabular}

Notes: $* * *$ significant at $1 \%, * *$ significant at $5 \%, *$ significant at $10 \%$ (based on $p$-values unadjusted for multiple-hypothesis testing). Clustered standard errors at the municipality level in parenthesis. Column (1) shows regression coefficient of the treatment for the whole sample (average effect). Columns (2) to (5) and (6) to (9) show coefficients of the regression that includes interaction terms of the treatment variable with SISBEN points and age, respectively. 
Table 37: Heterogeneous effects: Third follow-up Tablet effect on Financial Practices (ATM, MFA)

\begin{tabular}{lccccccc}
\hline & & \multicolumn{2}{c}{ Area } & \multicolumn{2}{c}{ Region } & \multicolumn{2}{c}{ Schooling } \\
& Total & Urban & Rural & Caribe & Pacifico & Primary & Secondary \\
& $(1)$ & $(2)$ & $(3)$ & $(4)$ & $(5)$ & $(6)$ & $(7)$ \\
\hline Manages household finances & 0.007 & 0.015 & -0.004 & $0.026^{* *}$ & -0.023 & -0.005 & 0.022 \\
& $(0.012)$ & $(0.014)$ & $(0.014)$ & $(0.011)$ & $(0.024)$ & $(0.016)$ & $(0.014)$ \\
Keeps written track of accounts & 0.020 & -0.018 & 0.050 & 0.030 & -0.040 & 0.003 & 0.023 \\
& $(0.024)$ & $(0.036)$ & $(0.031)$ & $(0.028)$ & $(0.041)$ & $(0.037)$ & $(0.033)$ \\
Withdrew last MFA transfer & $0.038^{* *}$ & 0.024 & 0.048 & 0.026 & 0.045 & 0.027 & $0.048^{* * *}$ \\
& $(0.019)$ & $(0.020)$ & $(0.029)$ & $(0.022)$ & $(0.033)$ & $(0.040)$ & $(0.017)$ \\
Accompanied when withdrew & 0.035 & 0.048 & 0.006 & 0.025 & 0.043 & 0.050 & 0.018 \\
& $(0.030)$ & $(0.045)$ & $(0.044)$ & $(0.036)$ & $(0.058)$ & $(0.038)$ & $(0.036)$ \\
Has money in MFA account (today) & 0.044 & $0.087^{*}$ & -0.021 & 0.052 & 0.013 & 0.012 & $0.078^{*}$ \\
& $(0.035)$ & $(0.047)$ & $(0.044)$ & $(0.043)$ & $(0.067)$ & $(0.043)$ & $(0.043)$ \\
Leaves money in MFA account & 0.019 & 0.018 & 0.019 & 0.005 & 0.034 & 0.033 & 0.011 \\
& $(0.031)$ & $(0.040)$ & $(0.035)$ & $(0.040)$ & $(0.050)$ & $(0.042)$ & $(0.035)$ \\
Someone helped use ATM & 0.016 & 0.073 & -0.050 & 0.024 & 0.046 & 0.005 & 0.030 \\
& $(0.034)$ & $(0.044)$ & $(0.059)$ & $(0.041)$ & $(0.061)$ & $(0.050)$ & $(0.050)$ \\
Feels can teach ATM use & -0.012 & -0.021 & -0.002 & -0.008 & -0.044 & -0.009 & -0.005 \\
Has taught someone use ATM & $(0.018)$ & $(0.026)$ & $(0.033)$ & $(0.023)$ & $(0.029)$ & $(0.033)$ & $(0.024)$ \\
Has an MFA card & 0.025 & 0.036 & 0.017 & 0.038 & -0.012 & 0.007 & 0.054 \\
& $(0.022)$ & $(0.032)$ & $(0.030)$ & $(0.028)$ & $(0.031)$ & $(0.025)$ & $(0.033)$ \\
& $0.027^{* *}$ & $0.017^{*}$ & 0.022 & 0.011 & 0.023 & $0.034^{* *}$ & $0.021^{*}$ \\
& $(0.010)$ & $(0.009)$ & $(0.018)$ & $(0.025)$ & $(0.021)$ & $(0.013)$ & $(0.011)$ \\
\hline
\end{tabular}

Notes: *** significant at $1 \%, * *$ significant at $5 \%, *$ significant at $10 \%$ (based on $p$-values unadjusted for multiple-hypothesis testing). Clustered standard errors at the municipality level in parenthesis. Column (1) shows regression coefficient of the treatment for the whole sample (average effect). Columns (2) to (7) show coefficients of the treatment in the regression for each sub-sample. 
Table 38: Heterogeneous effects: Third follow-up Tablet effect on Financial Practices (ATM, MFA)

\begin{tabular}{|c|c|c|c|c|c|c|c|c|c|}
\hline & \multirow[b]{2}{*}{$\begin{array}{c}\text { Total } \\
(1)\end{array}$} & \multicolumn{4}{|c|}{ Interactions with SISBEN points quartiles } & \multicolumn{4}{|c|}{ Interactions with age quartiles } \\
\hline & & $\begin{array}{c}\text { Treat } \\
(2)\end{array}$ & $\begin{array}{c}\text { Treat*Q2 } \\
(3)\end{array}$ & $\begin{array}{c}\text { Treat*Q3 } \\
(4)\end{array}$ & $\begin{array}{c}\text { Treat* }{ }^{*} 4 \\
(5)\end{array}$ & $\begin{array}{c}\text { Treat } \\
(6)\end{array}$ & $\begin{array}{c}\text { Treat*Q2 } \\
(7)\end{array}$ & $\begin{array}{c}\text { Treat*Q3 } \\
(8)\end{array}$ & $\begin{array}{c}\text { Treat*Q4 } \\
(9)\end{array}$ \\
\hline Manages household finances & $\begin{array}{c}0.007 \\
(0.012)\end{array}$ & $\begin{array}{c}-0.026 \\
(0.023)\end{array}$ & $\begin{array}{c}0.058^{*} \\
(0.031)\end{array}$ & $\begin{array}{c}0.033 \\
(0.027)\end{array}$ & $\begin{array}{c}0.051^{*} \\
(0.030)\end{array}$ & $\begin{array}{c}0.005 \\
(0.025)\end{array}$ & $\begin{array}{c}0.008 \\
(0.031)\end{array}$ & $\begin{array}{c}0.005 \\
(0.023)\end{array}$ & $\begin{array}{c}-0.005 \\
(0.028)\end{array}$ \\
\hline Keeps written track of accounts & $\begin{array}{c}0.020 \\
(0.024)\end{array}$ & $\begin{array}{c}0.035 \\
(0.035)\end{array}$ & $\begin{array}{c}-0.094 \\
(0.062)\end{array}$ & $\begin{array}{c}0.022 \\
(0.058)\end{array}$ & $\begin{array}{c}0.010 \\
(0.054)\end{array}$ & $\begin{array}{c}0.020 \\
(0.050)\end{array}$ & $\begin{array}{l}-0.015 \\
(0.072)\end{array}$ & $\begin{array}{c}0.007 \\
(0.072)\end{array}$ & $\begin{array}{c}0.002 \\
(0.086)\end{array}$ \\
\hline Withdrew last MFA transfer & $\begin{array}{c}0.038^{* *} \\
(0.019)\end{array}$ & $\begin{array}{c}0.078^{* *} \\
(0.034)\end{array}$ & $\begin{array}{c}-0.057 \\
(0.050)\end{array}$ & $\begin{array}{c}-0.064 \\
(0.048)\end{array}$ & $\begin{array}{c}-0.051 \\
(0.042)\end{array}$ & $\begin{array}{c}0.023 \\
(0.030)\end{array}$ & $\begin{array}{c}0.066 \\
(0.040)\end{array}$ & $\begin{array}{c}0.005 \\
(0.039)\end{array}$ & $\begin{array}{c}-0.014 \\
(0.051)\end{array}$ \\
\hline Accompanied when withdrew & $\begin{array}{c}0.035 \\
(0.030)\end{array}$ & $\begin{array}{c}0.062 \\
(0.044)\end{array}$ & $\begin{array}{l}-0.012 \\
(0.069)\end{array}$ & $\begin{array}{l}-0.056 \\
(0.075)\end{array}$ & $\begin{array}{l}-0.038 \\
(0.063)\end{array}$ & $\begin{array}{c}0.005 \\
(0.051)\end{array}$ & $\begin{array}{c}0.011 \\
(0.058)\end{array}$ & $\begin{array}{c}0.070 \\
(0.060)\end{array}$ & $\begin{array}{c}0.035 \\
(0.069)\end{array}$ \\
\hline Has money in MFA account (today) & $\begin{array}{c}0.044 \\
(0.035)\end{array}$ & $\begin{array}{c}-0.031 \\
(0.047)\end{array}$ & $\begin{array}{c}0.102 \\
(0.083)\end{array}$ & $\begin{array}{c}0.092 \\
(0.080)\end{array}$ & $\begin{array}{c}0.156^{* *} \\
(0.066)\end{array}$ & $\begin{array}{c}0.023 \\
(0.062)\end{array}$ & $\begin{array}{c}0.042 \\
(0.084)\end{array}$ & $\begin{array}{c}0.035 \\
(0.090)\end{array}$ & $\begin{array}{l}-0.001 \\
(0.081)\end{array}$ \\
\hline Leaves money in MFA account & $\begin{array}{c}0.019 \\
(0.031)\end{array}$ & $\begin{array}{c}0.022 \\
(0.045)\end{array}$ & $\begin{array}{c}-0.025 \\
(0.089)\end{array}$ & $\begin{array}{c}0.010 \\
(0.071)\end{array}$ & $\begin{array}{c}-0.001 \\
(0.070)\end{array}$ & $\begin{array}{c}-0.054 \\
(0.057)\end{array}$ & $\begin{array}{c}0.073 \\
(0.083)\end{array}$ & $\begin{array}{c}0.134^{*} \\
(0.076)\end{array}$ & $\begin{array}{c}0.079 \\
(0.078)\end{array}$ \\
\hline Someone helped use ATM & $\begin{array}{c}0.016 \\
(0.034)\end{array}$ & $\begin{array}{c}-0.070 \\
(0.067)\end{array}$ & $\begin{array}{c}0.076 \\
(0.118)\end{array}$ & $\begin{array}{c}0.053 \\
(0.111)\end{array}$ & $\begin{array}{c}0.248^{* * *} \\
(0.086)\end{array}$ & $\begin{array}{c}-0.020 \\
(0.091)\end{array}$ & $\begin{array}{c}0.091 \\
(0.112)\end{array}$ & $\begin{array}{c}0.007 \\
(0.108)\end{array}$ & $\begin{array}{c}0.040 \\
(0.112)\end{array}$ \\
\hline Feels can teach ATM use & $\begin{array}{c}-0.012 \\
(0.018)\end{array}$ & $\begin{array}{c}-0.046 \\
(0.037)\end{array}$ & $\begin{array}{c}0.008 \\
(0.061)\end{array}$ & $\begin{array}{c}0.081 \\
(0.062)\end{array}$ & $\begin{array}{c}0.050 \\
(0.056)\end{array}$ & $\begin{array}{c}-0.049 \\
(0.043)\end{array}$ & $\begin{array}{c}0.082 \\
(0.064)\end{array}$ & $\begin{array}{c}-0.025 \\
(0.069)\end{array}$ & $\begin{array}{c}0.088 \\
(0.075)\end{array}$ \\
\hline Has taught someone use ATM & $\begin{array}{c}0.025 \\
(0.022)\end{array}$ & $\begin{array}{c}0.001 \\
(0.038)\end{array}$ & $\begin{array}{c}-0.002 \\
(0.061)\end{array}$ & $\begin{array}{c}0.068 \\
(0.062)\end{array}$ & $\begin{array}{c}0.039 \\
(0.060)\end{array}$ & $\begin{array}{c}0.019 \\
(0.059)\end{array}$ & $\begin{array}{c}0.013 \\
(0.075)\end{array}$ & $\begin{array}{c}-0.041 \\
(0.065)\end{array}$ & $\begin{array}{c}0.054 \\
(0.076)\end{array}$ \\
\hline Has an MFA card & $\begin{array}{c}0.027^{* *} \\
(0.010)\end{array}$ & $\begin{array}{c}0.056^{* * *} \\
(0.018)\end{array}$ & $\begin{array}{c}-0.073^{* * *} \\
(0.020)\end{array}$ & $\begin{array}{l}-0.010 \\
(0.026)\end{array}$ & $\begin{array}{c}-0.047^{*} \\
(0.027)\end{array}$ & $\begin{array}{c}0.056^{*} \\
(0.031)\end{array}$ & $\begin{array}{c}-0.064^{*} \\
(0.036)\end{array}$ & $\begin{array}{l}-0.017 \\
(0.031)\end{array}$ & $\begin{array}{l}-0.029 \\
(0.032)\end{array}$ \\
\hline
\end{tabular}

Notes: *** significant at $1 \%, * *$ significant at $5 \%, *$ significant at $10 \%$ (based on $p$-values unadjusted for multiple-hypothesis testing). Clustered standard errors at the municipality level in parenthesis. Column (1) shows regression coefficient of the treatment for the whole sample (average effect). Columns (2) to (5) and (6) to (9) show coefficients of the regression that includes interaction terms of the treatment variable with SISBEN points and age, respectively. 
Table 39: Heterogeneous effects: First follow-up Tablet (Pooled Treatment) effect on Financial Practices (Budgeting)

\begin{tabular}{lcccccccc}
\hline & \multicolumn{3}{c}{ Area } & \multicolumn{3}{c}{ Region } & \multicolumn{3}{c}{ Schooling } \\
& Total & Urban & Rural & Caribe & Pacifico & Primary & Secondary \\
& $(1)$ & $(2)$ & $(3)$ & $(4)$ & $(5)$ & $(6)$ & $(7)$ \\
\hline In case of a 350k emergency & & & & & & & \\
Would use savings & $0.171^{* * *}$ & $0.135^{* * *}$ & $0.204^{* * *}$ & $0.202^{* * *}$ & $0.099^{* *}$ & $0.146^{* * *}$ & $0.192^{* * *}$ \\
& $(0.023)$ & $(0.034)$ & $(0.028)$ & $(0.027)$ & $(0.036)$ & $(0.029)$ & $(0.027)$ \\
Would use loans & $-0.161^{* * *}$ & $-0.125^{* * *}$ & $-0.191^{* * *}$ & $-0.187^{* * *}$ & $-0.094^{* *}$ & $-0.133^{* * *}$ & $-0.188^{* * *}$ \\
& $(0.023)$ & $(0.035)$ & $(0.027)$ & $(0.027)$ & $(0.038)$ & $(0.029)$ & $(0.029)$ \\
Would sell or pawn something & -0.006 & -0.002 & -0.013 & -0.011 & -0.000 & -0.007 & -0.004 \\
& $(0.007)$ & $(0.009)$ & $(0.013)$ & $(0.009)$ & $(0.009)$ & $(0.012)$ & $(0.009)$
\end{tabular}

In case of receiving $300 \mathrm{k}$ extra

Would save

Would spend on healthcare or education

Would build, improve or buy a house

Would spend on household expenses

Would invest in business

Was able to cover household expenses

Household weekly expenditure

Notes: $* * *$ significant at $1 \%, * *$ significant at $5 \%, *$ significant at $10 \%$ (based on $p$-values unadjusted for multiple-hypothesis testing). Clustered standard errors at the municipality level in parenthesis. Column (1) shows regression coefficient of the treatment for the whole sample (average effect). Columns (2) to (7) show coefficients of the treatment in the regression for each sub-sample. 
Table 40: Heterogeneous effects: First follow-up Tablet (Pooled Treatment) effect on Financial Practices (Budgeting)

\begin{tabular}{|c|c|c|c|c|c|c|c|c|c|}
\hline & \multirow[b]{2}{*}{$\begin{array}{c}\text { Total } \\
(1)\end{array}$} & \multicolumn{4}{|c|}{ Interactions with SISBEN points quartiles } & \multicolumn{4}{|c|}{ Interactions with age quartiles } \\
\hline & & $\begin{array}{c}\text { Treat } \\
(2)\end{array}$ & $\begin{array}{c}\text { Treat*Q2 } \\
\text { (3) }\end{array}$ & $\begin{array}{c}\text { Treat*Q3 } \\
\text { (4) }\end{array}$ & $\begin{array}{c}\text { Treat*Q4 } \\
\text { (5) }\end{array}$ & $\begin{array}{c}\text { Treat } \\
(6)\end{array}$ & $\begin{array}{c}\text { Treat*Q2 } \\
(7)\end{array}$ & $\begin{array}{c}\text { Treat*Q3 } \\
(8)\end{array}$ & $\begin{array}{c}\text { Treat*Q4 } \\
\text { (9) }\end{array}$ \\
\hline \multicolumn{10}{|l|}{ In case of a $350 \mathrm{k}$ emergency } \\
\hline Would use savings & $\begin{array}{c}0.171^{* * *} \\
(0.023)\end{array}$ & $\begin{array}{c}0.189^{* * *} \\
(0.035)\end{array}$ & $\begin{array}{c}0.013 \\
(0.052)\end{array}$ & $\begin{array}{c}-0.053 \\
(0.051)\end{array}$ & $\begin{array}{c}-0.045 \\
(0.043)\end{array}$ & $\begin{array}{c}0.165^{* * *} \\
(0.042)\end{array}$ & $\begin{array}{c}0.053 \\
(0.054)\end{array}$ & $\begin{array}{c}-0.009 \\
(0.048)\end{array}$ & $\begin{array}{c}-0.015 \\
(0.049)\end{array}$ \\
\hline Would use loans & $\begin{array}{c}-0.161^{* * *} \\
(0.023)\end{array}$ & $\begin{array}{c}-0.189^{* * *} \\
(0.032)\end{array}$ & $\begin{array}{c}-0.001 \\
(0.055)\end{array}$ & $\begin{array}{c}0.075 \\
(0.049)\end{array}$ & $\begin{array}{c}0.053 \\
(0.048)\end{array}$ & $\begin{array}{c}-0.163^{* * *} \\
(0.041)\end{array}$ & $\begin{array}{c}-0.059 \\
(0.053)\end{array}$ & $\begin{array}{c}0.038 \\
(0.051)\end{array}$ & $\begin{array}{c}0.028 \\
(0.047)\end{array}$ \\
\hline Would sell or pawn something & $\begin{array}{c}-0.006 \\
(0.007)\end{array}$ & $\begin{array}{c}-0.001 \\
(0.014)\end{array}$ & $\begin{array}{c}-0.007 \\
(0.019)\end{array}$ & $\begin{array}{c}-0.014 \\
(0.019)\end{array}$ & $\begin{array}{c}-0.002 \\
(0.019)\end{array}$ & $\begin{array}{c}-0.012 \\
(0.010)\end{array}$ & $\begin{array}{c}0.013 \\
(0.017)\end{array}$ & $\begin{array}{c}-0.013 \\
(0.022)\end{array}$ & $\begin{array}{c}0.023 \\
(0.020)\end{array}$ \\
\hline
\end{tabular}

Would look for a job

In case of receiving $300 \mathrm{k}$ extra

Would save

Would spend on healthcare or education

Would build, improve or buy a house

Would spend on household expenses

Would invest in business

Was able to cover household expenses

Household weekly expenditure

Notes: *** significant at $1 \%, * *$ significant at $5 \%, *$ significant at $10 \%$ (based on $p$-values unadjusted for multiple-hypothesis testing). Clustered standard errors at the municipality level in parenthesis. Column (1) shows regression coefficient of the treatment for the whole sample (average effect). Columns (2) to (5) and (6) to (9) show coefficients of the regression that includes interaction terms of the treatment variable with SISBEN points and age, respectively. 
Table 41: Heterogeneous effects: Second follow-up Tablet (Pooled Treatment) effect on Financial Practices (Budgeting)

\begin{tabular}{|c|c|c|c|c|c|c|c|}
\hline & \multirow[b]{2}{*}{$\begin{array}{c}\text { Total } \\
(1)\end{array}$} & \multicolumn{2}{|c|}{ Area } & \multicolumn{2}{|c|}{ Region } & \multicolumn{2}{|c|}{ Schooling } \\
\hline & & $\begin{array}{l}\text { Urban } \\
(2)\end{array}$ & $\begin{array}{c}\text { Rural } \\
(3)\end{array}$ & $\begin{array}{c}\text { Caribe } \\
(4)\end{array}$ & $\begin{array}{c}\text { Pacifico } \\
\text { (5) }\end{array}$ & $\begin{array}{c}\text { Primary } \\
(6)\end{array}$ & $\begin{array}{c}\text { Secondary } \\
(7)\end{array}$ \\
\hline \multicolumn{8}{|l|}{ In case of a $350 \mathrm{k}$ emergency } \\
\hline Would use savings & $\begin{array}{c}0.084^{* * *} \\
(0.010)\end{array}$ & $\begin{array}{c}0.066^{* * *} \\
(0.017)\end{array}$ & $\begin{array}{c}0.099 * * * \\
(0.015)\end{array}$ & $\begin{array}{c}0.089^{* * *} \\
(0.013)\end{array}$ & $\begin{array}{c}0.067^{* * *} \\
(0.020)\end{array}$ & $\begin{array}{c}0.080^{* * *} \\
(0.012)\end{array}$ & $\begin{array}{c}0.084^{* * *} \\
(0.017)\end{array}$ \\
\hline Would use loans & $\begin{array}{c}-0.109^{* * *} \\
(0.017)\end{array}$ & $\begin{array}{c}-0.104^{* * * *} \\
(0.022)\end{array}$ & $\begin{array}{c}-0.101^{* * *} \\
(0.030)\end{array}$ & $\begin{array}{c}-0.123^{* * *} \\
(0.019)\end{array}$ & $\begin{array}{c}-0.068^{*} \\
(0.034)\end{array}$ & $\begin{array}{c}-0.107^{* * *} \\
(0.027)\end{array}$ & $\begin{array}{c}-0.113^{* * *} \\
(0.021)\end{array}$ \\
\hline Would sell or pawn something & $\begin{array}{c}0.023 \\
(0.014)\end{array}$ & $\begin{array}{c}0.039^{* *} \\
(0.015)\end{array}$ & $\begin{array}{c}-0.003 \\
(0.023)\end{array}$ & $\begin{array}{c}0.034^{*} \\
(0.018)\end{array}$ & $\begin{array}{c}-0.009 \\
(0.025)\end{array}$ & $\begin{array}{c}0.022 \\
(0.024)\end{array}$ & $\begin{array}{l}0.029^{* *} \\
(0.014)\end{array}$ \\
\hline Would look for a job & $\begin{array}{c}-0.014^{* *} \\
(0.006)\end{array}$ & $\begin{array}{c}-0.025^{* * * *} \\
(0.009)\end{array}$ & $\begin{array}{c}-0.003 \\
(0.006)\end{array}$ & $\begin{array}{c}-0.012 \\
(0.008)\end{array}$ & $\begin{array}{c}-0.021^{* *} \\
(0.009)\end{array}$ & $\begin{array}{l}-0.014^{*} \\
(0.008)\end{array}$ & $\begin{array}{l}-0.015^{*} \\
(0.008)\end{array}$ \\
\hline \multicolumn{8}{|l|}{ In case of receiving $300 \mathrm{k}$ extra } \\
\hline Would save & $\begin{array}{l}0.046^{* *} \\
(0.018)\end{array}$ & $\begin{array}{c}0.030 \\
(0.029)\end{array}$ & $\begin{array}{l}0.058^{* *} \\
(0.023)\end{array}$ & $\begin{array}{l}0.052^{* *} \\
(0.023)\end{array}$ & $\begin{array}{c}0.028 \\
(0.028)\end{array}$ & $\begin{array}{c}0.068^{* * *} \\
(0.022)\end{array}$ & $\begin{array}{c}0.026 \\
(0.022)\end{array}$ \\
\hline Would spend on healthcare or education & $\begin{array}{c}0.008 \\
(0.012)\end{array}$ & $\begin{array}{c}0.020 \\
(0.017)\end{array}$ & $\begin{array}{c}-0.008 \\
(0.015)\end{array}$ & $\begin{array}{c}-0.003 \\
(0.014)\end{array}$ & $\begin{array}{c}0.017 \\
(0.018)\end{array}$ & $\begin{array}{c}0.011 \\
(0.015)\end{array}$ & $\begin{array}{c}0.003 \\
(0.015)\end{array}$ \\
\hline Would build, improve or buy a house & $\begin{array}{c}-0.019 \\
(0.019)\end{array}$ & $\begin{array}{c}-0.007 \\
(0.025)\end{array}$ & $\begin{array}{c}-0.030 \\
(0.026)\end{array}$ & $\begin{array}{c}-0.014 \\
(0.021)\end{array}$ & $\begin{array}{c}-0.024 \\
(0.037)\end{array}$ & $\begin{array}{c}-0.006 \\
(0.022)\end{array}$ & $\begin{array}{c}-0.025 \\
(0.027)\end{array}$ \\
\hline Would spend on household expenses & $\begin{array}{l}-0.019^{*} \\
(0.010)\end{array}$ & $\begin{array}{l}-0.015 \\
(0.017)\end{array}$ & $\begin{array}{c}-0.022^{*} \\
(0.012)\end{array}$ & $\begin{array}{l}-0.021^{*} \\
(0.011)\end{array}$ & $\begin{array}{c}-0.008 \\
(0.023)\end{array}$ & $\begin{array}{c}-0.023^{* *} \\
(0.011)\end{array}$ & $\begin{array}{c}-0.016 \\
(0.013)\end{array}$ \\
\hline Would invest in business & $\begin{array}{c}0.013 \\
(0.015)\end{array}$ & $\begin{array}{c}-0.011 \\
(0.022)\end{array}$ & $\begin{array}{c}0.033^{*} \\
(0.018)\end{array}$ & $\begin{array}{c}0.004 \\
(0.017)\end{array}$ & $\begin{array}{c}0.034 \\
(0.032)\end{array}$ & $\begin{array}{c}0.018 \\
(0.016)\end{array}$ & $\begin{array}{c}0.014 \\
(0.019)\end{array}$ \\
\hline Was able to cover household expenses & $\begin{array}{c}0.036^{*} \\
(0.021)\end{array}$ & $\begin{array}{c}0.024 \\
(0.035)\end{array}$ & $\begin{array}{c}0.042 \\
(0.028)\end{array}$ & $\begin{array}{c}0.021 \\
(0.025)\end{array}$ & $\begin{array}{l}0.090^{* *} \\
(0.036)\end{array}$ & $\begin{array}{l}0.071^{* *} \\
(0.028)\end{array}$ & $\begin{array}{c}0.011 \\
(0.027)\end{array}$ \\
\hline Household weekly expenditure & $\begin{array}{c}0.007 \\
(0.046)\end{array}$ & $\begin{array}{c}0.021 \\
(0.071)\end{array}$ & $\begin{array}{c}-0.002 \\
(0.062)\end{array}$ & $\begin{array}{c}0.011 \\
(0.062)\end{array}$ & $\begin{array}{c}0.022 \\
(0.074)\end{array}$ & $\begin{array}{c}0.051 \\
(0.058)\end{array}$ & $\begin{array}{c}-0.056 \\
(0.065)\end{array}$ \\
\hline
\end{tabular}

Notes: *** significant at $1 \%, * *$ significant at $5 \%, *$ significant at $10 \%$ (based on $p$-values unadjusted for multiple-hypothesis testing). Clustered standard errors at the municipality level in parenthesis. Column (1) shows regression coefficient of the treatment for the whole sample (average effect). Columns (2) to (7) show coefficients of the treatment in the regression for each sub-sample. 
Table 42: Heterogeneous effects: Second follow-up Tablet (Pooled Treatment) effect on Financial Practices (Budgeting)

\begin{tabular}{|c|c|c|c|c|c|c|c|c|c|}
\hline & \multirow[b]{2}{*}{$\begin{array}{l}\text { Total } \\
(1)\end{array}$} & \multicolumn{4}{|c|}{ Interactions with SISBEN points quartiles } & \multicolumn{4}{|c|}{ Interactions with age quartiles } \\
\hline & & $\begin{array}{c}\text { Treat } \\
(2)\end{array}$ & $\begin{array}{c}\text { Treat*Q2 } \\
\text { (3) }\end{array}$ & $\begin{array}{c}\text { Treat*Q3 } \\
\text { (4) }\end{array}$ & $\begin{array}{c}\text { Treat*Q44 } \\
(5)\end{array}$ & $\begin{array}{l}\text { Treat } \\
(6)\end{array}$ & $\begin{array}{c}\text { Treat*Q2 } \\
(7)\end{array}$ & $\begin{array}{c}\text { Treat*Q3 } \\
\text { (8) }\end{array}$ & $\begin{array}{c}\text { Treat* }{ }^{*} 4 \\
(9)\end{array}$ \\
\hline \multicolumn{10}{|l|}{ In case of a $350 \mathrm{k}$ emergency } \\
\hline Would use savings & $\begin{array}{c}0.084^{* * *} \\
(0.010)\end{array}$ & $\begin{array}{c}0.079^{* * *} \\
(0.019)\end{array}$ & $\begin{array}{c}0.050^{*} \\
(0.027)\end{array}$ & $\begin{array}{c}-0.010 \\
(0.034)\end{array}$ & $\begin{array}{c}-0.015 \\
(0.033)\end{array}$ & $\begin{array}{c}0.021 \\
(0.024)\end{array}$ & $\begin{array}{c}0.101 * * * \\
(0.033)\end{array}$ & $\begin{array}{c}0.047 \\
(0.035)\end{array}$ & $\begin{array}{l}0.100^{* *} \\
(0.039)\end{array}$ \\
\hline Would use loans & $\begin{array}{c}-0.109 * * * \\
(0.017)\end{array}$ & $\begin{array}{c}-0.090^{* * *} \\
(0.029)\end{array}$ & $\begin{array}{c}-0.071^{* *} \\
(0.035)\end{array}$ & $\begin{array}{c}-0.022 \\
(0.041)\end{array}$ & $\begin{array}{c}0.009 \\
(0.050)\end{array}$ & $\begin{array}{c}-0.036 \\
(0.033)\end{array}$ & $\begin{array}{c}-0.096^{* *} \\
(0.043)\end{array}$ & $\begin{array}{l}-0.098^{*} \\
(0.050)\end{array}$ & $\begin{array}{l}-0.091^{*} \\
(0.050)\end{array}$ \\
\hline Would sell or pawn something & $\begin{array}{c}0.023 \\
(0.014)\end{array}$ & $\begin{array}{c}0.008 \\
(0.024)\end{array}$ & $\begin{array}{c}0.020 \\
(0.029)\end{array}$ & $\begin{array}{c}0.027 \\
(0.033)\end{array}$ & $\begin{array}{c}0.016 \\
(0.034)\end{array}$ & $\begin{array}{c}0.019 \\
(0.021)\end{array}$ & $\begin{array}{c}-0.020 \\
(0.031)\end{array}$ & $\begin{array}{c}0.050 \\
(0.036)\end{array}$ & $\begin{array}{c}-0.014 \\
(0.030)\end{array}$ \\
\hline Would look for a job & $\begin{array}{c}-0.014^{* *} \\
(0.006)\end{array}$ & $\begin{array}{c}-0.024^{* *} \\
(0.009)\end{array}$ & $\begin{array}{c}0.022 \\
(0.016)\end{array}$ & $\begin{array}{c}0.003 \\
(0.015)\end{array}$ & $\begin{array}{c}0.015 \\
(0.018)\end{array}$ & $\begin{array}{c}-0.012 \\
(0.015)\end{array}$ & $\begin{array}{c}-0.002 \\
(0.019)\end{array}$ & $\begin{array}{c}-0.001 \\
(0.017)\end{array}$ & $\begin{array}{c}-0.003 \\
(0.018)\end{array}$ \\
\hline \multicolumn{10}{|l|}{ In case of receiving $300 \mathrm{k}$ extra } \\
\hline Would save & $\begin{array}{l}0.046^{* *} \\
(0.018)\end{array}$ & $\begin{array}{l}0.061^{* *} \\
(0.027)\end{array}$ & $\begin{array}{c}-0.009 \\
(0.037)\end{array}$ & $\begin{array}{c}-0.025 \\
(0.042)\end{array}$ & $\begin{array}{c}-0.028 \\
(0.039)\end{array}$ & $\begin{array}{c}0.046 \\
(0.028)\end{array}$ & $\begin{array}{c}-0.012 \\
(0.038)\end{array}$ & $\begin{array}{c}-0.036 \\
(0.036)\end{array}$ & $\begin{array}{c}0.046 \\
(0.038)\end{array}$ \\
\hline Would spend on healthcare or education & $\begin{array}{c}0.008 \\
(0.012)\end{array}$ & $\begin{array}{c}0.002 \\
(0.016)\end{array}$ & $\begin{array}{c}0.006 \\
(0.027)\end{array}$ & $\begin{array}{c}-0.012 \\
(0.034)\end{array}$ & $\begin{array}{c}0.022 \\
(0.029)\end{array}$ & $\begin{array}{c}-0.007 \\
(0.025)\end{array}$ & $\begin{array}{c}0.000 \\
(0.034)\end{array}$ & $\begin{array}{c}0.045 \\
(0.033)\end{array}$ & $\begin{array}{c}0.015 \\
(0.031)\end{array}$ \\
\hline Would build, improve or buy a house & $\begin{array}{c}-0.019 \\
(0.019)\end{array}$ & $\begin{array}{c}0.001 \\
(0.026)\end{array}$ & $\begin{array}{c}-0.030 \\
(0.046)\end{array}$ & $\begin{array}{c}0.024 \\
(0.048)\end{array}$ & $\begin{array}{c}-0.068 \\
(0.042)\end{array}$ & $\begin{array}{c}-0.022 \\
(0.031)\end{array}$ & $\begin{array}{c}-0.038 \\
(0.044)\end{array}$ & $\begin{array}{c}0.012 \\
(0.045)\end{array}$ & $\begin{array}{c}0.040 \\
(0.042)\end{array}$ \\
\hline Would spend on household expenses & $\begin{array}{l}-0.019^{*} \\
(0.010)\end{array}$ & $\begin{array}{c}-0.004 \\
(0.015)\end{array}$ & $\begin{array}{c}-0.025 \\
(0.023)\end{array}$ & $\begin{array}{c}-0.022 \\
(0.023)\end{array}$ & $\begin{array}{c}-0.019 \\
(0.024)\end{array}$ & $\begin{array}{c}-0.022 \\
(0.019)\end{array}$ & $\begin{array}{c}-0.001 \\
(0.024)\end{array}$ & $\begin{array}{c}0.032 \\
(0.027)\end{array}$ & $\begin{array}{c}-0.016 \\
(0.028)\end{array}$ \\
\hline Would invest in business & $\begin{array}{c}0.013 \\
(0.015)\end{array}$ & $\begin{array}{c}0.019 \\
(0.023)\end{array}$ & $\begin{array}{c}-0.014 \\
(0.042)\end{array}$ & $\begin{array}{c}0.036 \\
(0.042)\end{array}$ & $\begin{array}{c}-0.040 \\
(0.037)\end{array}$ & $\begin{array}{c}0.018 \\
(0.029)\end{array}$ & $\begin{array}{c}-0.015 \\
(0.036)\end{array}$ & $\begin{array}{c}-0.028 \\
(0.041)\end{array}$ & $\begin{array}{c}0.025 \\
(0.040)\end{array}$ \\
\hline Was able to cover household expenses & $\begin{array}{c}0.036^{*} \\
(0.021)\end{array}$ & $\begin{array}{c}0.029 \\
(0.036)\end{array}$ & $\begin{array}{c}0.041 \\
(0.060)\end{array}$ & $\begin{array}{c}-0.021 \\
(0.060)\end{array}$ & $\begin{array}{c}0.011 \\
(0.045)\end{array}$ & $\begin{array}{c}0.042 \\
(0.045)\end{array}$ & $\begin{array}{c}-0.011 \\
(0.065)\end{array}$ & $\begin{array}{c}-0.009 \\
(0.064)\end{array}$ & $\begin{array}{c}-0.003 \\
(0.059)\end{array}$ \\
\hline Household weekly expenditure & $\begin{array}{c}0.007 \\
(0.046)\end{array}$ & $\begin{array}{c}0.051 \\
(0.081)\end{array}$ & $\begin{array}{c}-0.013 \\
(0.123)\end{array}$ & $\begin{array}{c}-0.052 \\
(0.109)\end{array}$ & $\begin{array}{c}-0.136 \\
(0.123)\end{array}$ & $\begin{array}{c}0.030 \\
(0.089)\end{array}$ & $\begin{array}{c}-0.147 \\
(0.117)\end{array}$ & $\begin{array}{c}-0.012 \\
(0.133)\end{array}$ & $\begin{array}{c}0.070 \\
(0.127)\end{array}$ \\
\hline
\end{tabular}

Notes: $* * *$ significant at $1 \%, * *$ significant at $5 \%, *$ significant at $10 \%$ (based on $p$-values unadjusted for multiple-hypothesis testing). Clustered standard errors at the municipality level in parenthesis. Column (1) shows regression coefficient of the treatment for the whole sample (average effect). Columns (2) to (5) and (6) to (9) show coefficients of the regression that includes interaction terms of the treatment variable with SISBEN points and age, respectively. 
Table 43: Heterogeneous effects: Third follow-up Tablet (Pooled Treatment) effect on Financial Practices (Budgeting)

\begin{tabular}{|c|c|c|c|c|c|c|c|}
\hline & \multirow[b]{2}{*}{$\begin{array}{c}\text { Total } \\
(1)\end{array}$} & \multicolumn{2}{|c|}{ Area } & \multicolumn{2}{|c|}{ Region } & \multicolumn{2}{|c|}{ Schooling } \\
\hline & & $\begin{array}{l}\text { Urban } \\
(2)\end{array}$ & $\begin{array}{c}\text { Rural } \\
(3)\end{array}$ & $\begin{array}{c}\text { Caribe } \\
(4)\end{array}$ & $\begin{array}{c}\text { Pacifico } \\
(5)\end{array}$ & $\begin{array}{c}\text { Primary } \\
(6)\end{array}$ & $\begin{array}{c}\text { Secondary } \\
(7)\end{array}$ \\
\hline \multicolumn{8}{|l|}{ In case of a $350 \mathrm{k}$ emergency } \\
\hline Would use savings & $\begin{array}{c}0.061^{* * *} \\
(0.016)\end{array}$ & $\begin{array}{l}0.042^{* *} \\
(0.020)\end{array}$ & $\begin{array}{c}0.080^{* * *} \\
(0.022)\end{array}$ & $\begin{array}{c}0.063^{* * *} \\
(0.020)\end{array}$ & $\begin{array}{c}0.055^{* * *} \\
(0.019)\end{array}$ & $\begin{array}{c}0.068^{* * *} \\
(0.018)\end{array}$ & $\begin{array}{c}0.055^{* *} \\
(0.022)\end{array}$ \\
\hline Would use loans & $\begin{array}{c}-0.066^{* * *} \\
(0.020)\end{array}$ & $\begin{array}{c}-0.072^{* * *} \\
(0.023)\end{array}$ & $\begin{array}{c}-0.061^{* *} \\
(0.030)\end{array}$ & $\begin{array}{c}-0.084^{* * *} \\
(0.025)\end{array}$ & $\begin{array}{c}-0.022 \\
(0.027)\end{array}$ & $\begin{array}{c}-0.057^{* *} \\
(0.025)\end{array}$ & $\begin{array}{c}-0.075^{* * *} \\
(0.027)\end{array}$ \\
\hline Would sell or pawn something & $\begin{array}{c}0.007 \\
(0.010)\end{array}$ & $\begin{array}{c}0.021^{*} \\
(0.011)\end{array}$ & $\begin{array}{c}-0.007 \\
(0.015)\end{array}$ & $\begin{array}{c}0.018 \\
(0.013)\end{array}$ & $\begin{array}{c}-0.014 \\
(0.012)\end{array}$ & $\begin{array}{c}0.002 \\
(0.013)\end{array}$ & $\begin{array}{c}0.015 \\
(0.013)\end{array}$ \\
\hline Would look for a job & $\begin{array}{c}-0.000 \\
(0.007)\end{array}$ & $\begin{array}{c}0.009 \\
(0.007)\end{array}$ & $\begin{array}{c}-0.010 \\
(0.011)\end{array}$ & $\begin{array}{c}0.004 \\
(0.006)\end{array}$ & $\begin{array}{c}-0.012 \\
(0.015)\end{array}$ & $\begin{array}{c}-0.005 \\
(0.010)\end{array}$ & $\begin{array}{c}0.002 \\
(0.007)\end{array}$ \\
\hline \multicolumn{8}{|l|}{ In case of receiving $300 \mathrm{k}$ extra } \\
\hline Would save & $\begin{array}{l}0.042^{* *} \\
(0.017)\end{array}$ & $\begin{array}{c}0.022 \\
(0.020)\end{array}$ & $\begin{array}{l}0.057^{* *} \\
(0.026)\end{array}$ & $\begin{array}{l}0.034^{* *} \\
(0.016)\end{array}$ & $\begin{array}{c}0.060 \\
(0.040)\end{array}$ & $\begin{array}{c}0.076^{* * *} \\
(0.025)\end{array}$ & $\begin{array}{c}0.009 \\
(0.019)\end{array}$ \\
\hline Would spend on healthcare or education & $\begin{array}{c}0.004 \\
(0.009)\end{array}$ & $\begin{array}{c}0.004 \\
(0.016)\end{array}$ & $\begin{array}{c}0.006 \\
(0.012)\end{array}$ & $\begin{array}{c}0.012 \\
(0.012)\end{array}$ & $\begin{array}{c}-0.010 \\
(0.011)\end{array}$ & $\begin{array}{c}0.007 \\
(0.008)\end{array}$ & $\begin{array}{c}0.002 \\
(0.015)\end{array}$ \\
\hline Would build, improve or buy a house & $\begin{array}{c}0.016 \\
(0.019)\end{array}$ & $\begin{array}{c}0.041 \\
(0.025)\end{array}$ & $\begin{array}{c}-0.003 \\
(0.024)\end{array}$ & $\begin{array}{c}0.034 \\
(0.021)\end{array}$ & $\begin{array}{c}-0.023 \\
(0.039)\end{array}$ & $\begin{array}{c}0.018 \\
(0.023)\end{array}$ & $\begin{array}{c}0.012 \\
(0.025)\end{array}$ \\
\hline Would spend on household expenses & $\begin{array}{c}-0.012 \\
(0.017)\end{array}$ & $\begin{array}{c}0.014 \\
(0.024)\end{array}$ & $\begin{array}{l}-0.040^{*} \\
(0.022)\end{array}$ & $\begin{array}{c}-0.003 \\
(0.022)\end{array}$ & $\begin{array}{c}-0.030 \\
(0.029)\end{array}$ & $\begin{array}{c}-0.012 \\
(0.021)\end{array}$ & $\begin{array}{c}-0.008 \\
(0.023)\end{array}$ \\
\hline Would invest in business & $\begin{array}{c}0.022 \\
(0.014)\end{array}$ & $\begin{array}{c}0.013 \\
(0.018)\end{array}$ & $\begin{array}{c}0.021 \\
(0.018)\end{array}$ & $\begin{array}{c}0.021 \\
(0.016)\end{array}$ & $\begin{array}{c}0.024 \\
(0.033)\end{array}$ & $\begin{array}{c}0.032 \\
(0.020)\end{array}$ & $\begin{array}{c}0.013 \\
(0.016)\end{array}$ \\
\hline Was able to cover household expenses & $\begin{array}{c}0.075^{* * *} \\
(0.022)\end{array}$ & $\begin{array}{l}0.067^{* *} \\
(0.031)\end{array}$ & $\begin{array}{l}0.083^{* *} \\
(0.033)\end{array}$ & $\begin{array}{l}0.061^{* *} \\
(0.026)\end{array}$ & $\begin{array}{l}0.105^{* *} \\
(0.039)\end{array}$ & $\begin{array}{c}0.042 \\
(0.028)\end{array}$ & $\begin{array}{c}0.108^{* * *} \\
(0.028)\end{array}$ \\
\hline Household weekly expenditure & $\begin{array}{l}-0.009 \\
(0.057)\end{array}$ & $\begin{array}{l}-0.043 \\
(0.079)\end{array}$ & $\begin{array}{c}0.016 \\
(0.062)\end{array}$ & $\begin{array}{c}-0.051 \\
(0.069)\end{array}$ & $\begin{array}{c}0.092 \\
(0.090)\end{array}$ & $\begin{array}{c}-0.002 \\
(0.060)\end{array}$ & $\begin{array}{c}-0.038 \\
(0.074)\end{array}$ \\
\hline
\end{tabular}

Notes: *** significant at $1 \%, * *$ significant at $5 \%, *$ significant at $10 \%$ (based on $p$-values unadjusted for multiple-hypothesis testing). Clustered standard errors at the municipality level in parenthesis. Column (1) shows regression coefficient of the treatment for the whole sample (average effect). Columns (2) to (7) show coefficients of the treatment in the regression for each sub-sample. 
Table 44: Heterogeneous effects: Third follow-up Tablet (Pooled Treatment) effect on Financial Practices (Budgeting)

\begin{tabular}{|c|c|c|c|c|c|c|c|c|c|}
\hline & \multirow[b]{2}{*}{$\begin{array}{c}\text { Total } \\
(1)\end{array}$} & \multicolumn{4}{|c|}{ Interactions with SISBEN points quartiles } & \multicolumn{4}{|c|}{ Interactions with age quartiles } \\
\hline & & $\begin{array}{l}\text { Treat } \\
(2)\end{array}$ & $\begin{array}{c}\text { Treat*Q2 } \\
\text { (3) }\end{array}$ & $\begin{array}{c}\text { Treat*Q3 } \\
\text { (4) }\end{array}$ & $\begin{array}{c}\text { Treat*Q4 } \\
\text { (5) }\end{array}$ & $\begin{array}{l}\text { Treat } \\
(6)\end{array}$ & $\begin{array}{l}\text { Treat*Q2 } \\
(7)\end{array}$ & $\begin{array}{c}\text { Treat*Q3 } \\
\text { (8) }\end{array}$ & $\begin{array}{c}\text { Treat* }{ }^{*} 4 \\
(9)\end{array}$ \\
\hline \multicolumn{10}{|l|}{ In case of a $350 \mathrm{k}$ emergency } \\
\hline Would use savings & $\begin{array}{c}0.061^{* * *} \\
(0.016)\end{array}$ & $\begin{array}{l}0.075^{* *} \\
(0.030)\end{array}$ & $\begin{array}{c}-0.049 \\
(0.037)\end{array}$ & $\begin{array}{c}-0.004 \\
(0.043)\end{array}$ & $\begin{array}{c}-0.006 \\
(0.039)\end{array}$ & $\begin{array}{c}0.036 \\
(0.028)\end{array}$ & $\begin{array}{c}0.061 \\
(0.045)\end{array}$ & $\begin{array}{c}0.043 \\
(0.036)\end{array}$ & $\begin{array}{c}-0.003 \\
(0.033)\end{array}$ \\
\hline Would use loans & $\begin{array}{c}-0.066^{* * *} \\
(0.020)\end{array}$ & $\begin{array}{c}-0.052 \\
(0.036)\end{array}$ & $\begin{array}{c}0.006 \\
(0.049)\end{array}$ & $\begin{array}{c}-0.035 \\
(0.050)\end{array}$ & $\begin{array}{c}-0.032 \\
(0.049)\end{array}$ & $\begin{array}{c}-0.031 \\
(0.028)\end{array}$ & $\begin{array}{l}-0.103^{*} \\
(0.054)\end{array}$ & $\begin{array}{c}-0.064 \\
(0.043)\end{array}$ & $\begin{array}{c}0.025 \\
(0.042)\end{array}$ \\
\hline Would sell or pawn something & $\begin{array}{c}0.007 \\
(0.010)\end{array}$ & $\begin{array}{c}-0.008 \\
(0.019)\end{array}$ & $\begin{array}{c}0.017 \\
(0.026)\end{array}$ & $\begin{array}{c}0.009 \\
(0.029)\end{array}$ & $\begin{array}{c}0.038 \\
(0.028)\end{array}$ & $\begin{array}{c}-0.000 \\
(0.013)\end{array}$ & $\begin{array}{c}0.030 \\
(0.023)\end{array}$ & $\begin{array}{c}0.013 \\
(0.023)\end{array}$ & $\begin{array}{c}-0.015 \\
(0.025)\end{array}$ \\
\hline Would look for a job & $\begin{array}{c}-0.000 \\
(0.007)\end{array}$ & $\begin{array}{c}-0.014 \\
(0.015)\end{array}$ & $\begin{array}{c}0.019 \\
(0.020)\end{array}$ & $\begin{array}{c}0.027 \\
(0.018)\end{array}$ & $\begin{array}{c}0.012 \\
(0.019)\end{array}$ & $\begin{array}{c}-0.000 \\
(0.009)\end{array}$ & $\begin{array}{c}-0.004 \\
(0.020)\end{array}$ & $\begin{array}{c}0.006 \\
(0.014)\end{array}$ & $\begin{array}{c}-0.002 \\
(0.020)\end{array}$ \\
\hline \multicolumn{10}{|l|}{ In case of receiving 300k extra } \\
\hline Would save & $\begin{array}{l}0.042^{* *} \\
(0.017)\end{array}$ & $\begin{array}{c}0.091^{* * *} \\
(0.028)\end{array}$ & $\begin{array}{l}-0.073^{*} \\
(0.042)\end{array}$ & $\begin{array}{l}-0.072^{*} \\
(0.039)\end{array}$ & $\begin{array}{c}-0.067 \\
(0.042)\end{array}$ & $\begin{array}{c}0.032 \\
(0.027)\end{array}$ & $\begin{array}{c}0.006 \\
(0.041)\end{array}$ & $\begin{array}{c}0.043 \\
(0.041)\end{array}$ & $\begin{array}{c}-0.011 \\
(0.042)\end{array}$ \\
\hline Would spend on healthcare or education & $\begin{array}{c}0.004 \\
(0.009)\end{array}$ & $\begin{array}{c}-0.001 \\
(0.015)\end{array}$ & $\begin{array}{c}0.018 \\
(0.020)\end{array}$ & $\begin{array}{c}-0.005 \\
(0.022)\end{array}$ & $\begin{array}{c}0.011 \\
(0.027)\end{array}$ & $\begin{array}{c}0.005 \\
(0.012)\end{array}$ & $\begin{array}{c}-0.008 \\
(0.018)\end{array}$ & $\begin{array}{c}-0.006 \\
(0.016)\end{array}$ & $\begin{array}{c}0.009 \\
(0.018)\end{array}$ \\
\hline Would build, improve or buy a house & $\begin{array}{c}0.016 \\
(0.019)\end{array}$ & $\begin{array}{c}-0.001 \\
(0.028)\end{array}$ & $\begin{array}{c}0.039 \\
(0.038)\end{array}$ & $\begin{array}{c}0.012 \\
(0.042)\end{array}$ & $\begin{array}{c}0.023 \\
(0.044)\end{array}$ & $\begin{array}{c}-0.006 \\
(0.031)\end{array}$ & $\begin{array}{c}0.041 \\
(0.043)\end{array}$ & $\begin{array}{c}0.031 \\
(0.047)\end{array}$ & $\begin{array}{c}0.011 \\
(0.045)\end{array}$ \\
\hline Would spend on household expenses & $\begin{array}{c}-0.012 \\
(0.017)\end{array}$ & $\begin{array}{c}-0.030 \\
(0.031)\end{array}$ & $\begin{array}{c}0.068 \\
(0.045)\end{array}$ & $\begin{array}{c}0.024 \\
(0.043)\end{array}$ & $\begin{array}{c}-0.007 \\
(0.052)\end{array}$ & $\begin{array}{c}0.009 \\
(0.035)\end{array}$ & $\begin{array}{c}-0.021 \\
(0.044)\end{array}$ & $\begin{array}{c}-0.017 \\
(0.036)\end{array}$ & $\begin{array}{c}-0.046 \\
(0.043)\end{array}$ \\
\hline Would invest in business & $\begin{array}{c}0.022 \\
(0.014)\end{array}$ & $\begin{array}{c}0.034 \\
(0.026)\end{array}$ & $\begin{array}{c}-0.005 \\
(0.030)\end{array}$ & $\begin{array}{c}0.007 \\
(0.033)\end{array}$ & $\begin{array}{c}-0.049 \\
(0.038)\end{array}$ & $\begin{array}{c}0.054^{*} \\
(0.028)\end{array}$ & $\begin{array}{c}-0.034 \\
(0.036)\end{array}$ & $\begin{array}{c}-0.029 \\
(0.042)\end{array}$ & $\begin{array}{l}-0.063^{*} \\
(0.034)\end{array}$ \\
\hline Was able to cover household expenses & $\begin{array}{c}0.075^{* * *} \\
(0.022)\end{array}$ & $\begin{array}{c}0.055 \\
(0.038)\end{array}$ & $\begin{array}{c}-0.025 \\
(0.064)\end{array}$ & $\begin{array}{c}0.060 \\
(0.066)\end{array}$ & $\begin{array}{c}0.050 \\
(0.055)\end{array}$ & $\begin{array}{l}0.107^{* *} \\
(0.050)\end{array}$ & $\begin{array}{c}0.000 \\
(0.070)\end{array}$ & $\begin{array}{c}-0.012 \\
(0.068)\end{array}$ & $\begin{array}{c}-0.110 \\
(0.066)\end{array}$ \\
\hline Household weekly expenditure & $\begin{array}{c}-0.009 \\
(0.057)\end{array}$ & $\begin{array}{c}0.007 \\
(0.092)\end{array}$ & $\begin{array}{c}-0.093 \\
(0.124)\end{array}$ & $\begin{array}{c}-0.006 \\
(0.134)\end{array}$ & $\begin{array}{c}0.018 \\
(0.130)\end{array}$ & $\begin{array}{c}0.015 \\
(0.100)\end{array}$ & $\begin{array}{c}0.014 \\
(0.134)\end{array}$ & $\begin{array}{c}0.037 \\
(0.142)\end{array}$ & $\begin{array}{c}-0.129 \\
(0.111)\end{array}$ \\
\hline
\end{tabular}

Notes: $* * *$ significant at $1 \%, * *$ significant at $5 \%, *$ significant at $10 \%$ (based on $p$-values unadjusted for multiple-hypothesis testing). Clustered standard errors at the municipality level in parenthesis. Column (1) shows regression coefficient of the treatment for the whole sample (average effect). Columns (2) to (5) and (6) to (9) show coefficients of the regression that includes interaction terms of the treatment variable with SISBEN points and age, respectively. 
Table 45: Heterogeneous effects: First follow-up Tablet effect on Financial Performance (Self-Reported)

\begin{tabular}{|c|c|c|c|c|c|c|c|}
\hline & \multirow[b]{2}{*}{$\begin{array}{l}\text { Total } \\
(1)\end{array}$} & \multicolumn{2}{|c|}{ Area } & \multicolumn{2}{|c|}{ Region } & \multicolumn{2}{|c|}{ Schooling } \\
\hline & & $\begin{array}{l}\text { Urban } \\
\text { (2) }\end{array}$ & $\begin{array}{c}\text { Rural } \\
(3)\end{array}$ & $\begin{array}{c}\text { Caribe } \\
(4)\end{array}$ & $\begin{array}{c}\text { Pacifico } \\
(5)\end{array}$ & $\begin{array}{c}\text { Primary } \\
(6)\end{array}$ & $\begin{array}{c}\text { Secondary } \\
(7)\end{array}$ \\
\hline \multicolumn{8}{|l|}{ Panel A: Probability of saving } \\
\hline Has formal or informal savings & $\begin{array}{c}0.146^{* * *} \\
(0.023)\end{array}$ & $\begin{array}{c}0.136^{* * *} \\
(0.030)\end{array}$ & $\begin{array}{c}0.153^{* * *} \\
(0.028)\end{array}$ & $\begin{array}{c}0.156^{* * *} \\
(0.030)\end{array}$ & $\begin{array}{c}0.123^{* * *} \\
(0.029)\end{array}$ & $\begin{array}{c}0.154^{* * *} \\
(0.025)\end{array}$ & $\begin{array}{c}0.136^{* * *} \\
(0.026)\end{array}$ \\
\hline Has formal savings & $\begin{array}{c}0.030 * * \\
(0.013)\end{array}$ & $\begin{array}{c}0.045^{* *} \\
(0.018)\end{array}$ & $\begin{array}{c}0.022 \\
(0.016)\end{array}$ & $\begin{array}{c}0.050^{* * *} \\
(0.018)\end{array}$ & $\begin{array}{l}-0.008 \\
(0.015)\end{array}$ & $\begin{array}{c}0.021 \\
(0.016)\end{array}$ & $\begin{array}{c}0.040^{* *} \\
(0.018)\end{array}$ \\
\hline Has informal savings & $\begin{array}{c}0.148^{* * *} \\
(0.022)\end{array}$ & $\begin{array}{c}0.133^{* * *} \\
(0.032)\end{array}$ & $\begin{array}{c}0.159^{* * *} \\
(0.026)\end{array}$ & $\begin{array}{c}0.155^{* * *} \\
(0.029)\end{array}$ & $\begin{array}{c}0.131^{* * *} \\
(0.028)\end{array}$ & $\begin{array}{c}0.165^{* * *} \\
(0.025)\end{array}$ & $\begin{array}{c}0.130^{* * *} \\
(0.027)\end{array}$ \\
\hline Has savings in a bank & $\begin{array}{c}0.029^{* * *} \\
(0.009)\end{array}$ & $\begin{array}{c}0.026^{*} \\
(0.014)\end{array}$ & $\begin{array}{c}0.031^{* *} \\
(0.014)\end{array}$ & $\begin{array}{c}0.028^{* *} \\
(0.011)\end{array}$ & $\begin{array}{c}0.034^{*} \\
(0.018)\end{array}$ & $\begin{array}{c}0.019^{*} \\
(0.011)\end{array}$ & $\begin{array}{c}0.035^{* *} \\
(0.013)\end{array}$ \\
\hline Has savings in a cooperative & $\begin{array}{c}0.017 \\
(0.011)\end{array}$ & $\begin{array}{c}0.026^{* *} \\
(0.013)\end{array}$ & $\begin{array}{c}0.011 \\
(0.013)\end{array}$ & $\begin{array}{c}0.041^{* * *} \\
(0.014)\end{array}$ & $\begin{array}{c}-0.040^{* *} \\
(0.016)\end{array}$ & $\begin{array}{c}0.018 \\
(0.015)\end{array}$ & $\begin{array}{c}0.018 \\
(0.014)\end{array}$ \\
\hline Has savings in piggy bank & $\begin{array}{c}0.148^{* * *} \\
(0.022)\end{array}$ & $\begin{array}{c}0.128^{* * *} \\
(0.031)\end{array}$ & $\begin{array}{c}0.167^{* * *} \\
(0.027)\end{array}$ & $\begin{array}{c}0.153^{* * *} \\
(0.029)\end{array}$ & $\begin{array}{c}0.138^{* * * *} \\
(0.026)\end{array}$ & $\begin{array}{c}0.159^{* * *} \\
(0.025)\end{array}$ & $\begin{array}{c}0.130^{* * *} \\
(0.027)\end{array}$ \\
\hline \multicolumn{8}{|l|}{ Panel B: Tobit estimates for savings } \\
\hline Total formal and informal savings & $\begin{array}{c}0.516^{* * *} \\
(0.158)\end{array}$ & $\begin{array}{c}0.696 \\
(0.458)\end{array}$ & $\begin{array}{l}0.542^{*} \\
(0.276)\end{array}$ & $\begin{array}{c}0.643^{* *} \\
(0.261)\end{array}$ & $\begin{array}{c}0.335 \\
(0.388)\end{array}$ & $\begin{array}{c}0.538^{* *} \\
(0.264)\end{array}$ & $\begin{array}{c}0.775^{* *} \\
(0.353)\end{array}$ \\
\hline Total formal savings & $\begin{array}{c}1.244^{*} \\
(0.659)\end{array}$ & $\begin{array}{c}3.010 \\
(1.836)\end{array}$ & $\begin{array}{c}-0.803 \\
(1.220)\end{array}$ & $\begin{array}{c}1.714 \\
(1.350)\end{array}$ & $\begin{array}{l}-1.643 \\
(1.503)\end{array}$ & $\begin{array}{c}1.202 \\
(1.367)\end{array}$ & $\begin{array}{l}-1.071 \\
(1.806)\end{array}$ \\
\hline Total informal savings & $\begin{array}{c}0.505^{* * *} \\
(0.161)\end{array}$ & $\begin{array}{c}0.581 \\
(0.506)\end{array}$ & $\begin{array}{c}0.604^{* *} \\
(0.292)\end{array}$ & $\begin{array}{c}0.703^{* *} \\
(0.339)\end{array}$ & $\begin{array}{c}0.423 \\
(0.327)\end{array}$ & $\begin{array}{c}0.298 \\
(0.301)\end{array}$ & $\begin{array}{c}1.150^{* * *} \\
(0.401)\end{array}$ \\
\hline Savings in a bank & $\begin{array}{c}3.214^{* * *} \\
(1.070)\end{array}$ & $\begin{array}{l}-0.124 \\
(0.237)\end{array}$ & $\begin{array}{c}0.126 \\
(0.132)\end{array}$ & $\begin{array}{l}-0.068 \\
(0.142)\end{array}$ & $\begin{array}{c}0.278 \\
(0.200)\end{array}$ & $\begin{array}{c}0.196 \\
(0.132)\end{array}$ & $\begin{array}{c}-0.094 \\
(0.237)\end{array}$ \\
\hline Savings in a cooperative & $\begin{array}{c}0.860 \\
(2.338)\end{array}$ & $\begin{array}{l}0.517^{*} \\
(0.312)\end{array}$ & $\begin{array}{l}-0.088 \\
(0.288)\end{array}$ & $\begin{array}{c}0.317 \\
(0.291)\end{array}$ & $\begin{array}{l}-0.565 \\
(0.350)\end{array}$ & $\begin{array}{c}0.113 \\
(0.301)\end{array}$ & $\begin{array}{c}-0.043 \\
(0.356)\end{array}$ \\
\hline Savings in piggy bank & $\begin{array}{c}0.464^{* * *} \\
(0.169)\end{array}$ & $\begin{array}{c}0.492 \\
(0.527)\end{array}$ & $\begin{array}{c}0.462 \\
(0.285)\end{array}$ & $\begin{array}{c}0.705^{* *} \\
(0.352)\end{array}$ & $\begin{array}{c}0.309 \\
(0.323)\end{array}$ & $\begin{array}{c}0.158 \\
(0.294)\end{array}$ & $\begin{array}{c}1.132^{* * *} \\
(0.407)\end{array}$ \\
\hline
\end{tabular}

Notes: $* * *$ significant at $1 \%, * *$ significant at $5 \%,{ }^{*}$ significant at $10 \%$ (based on $p$-values unadjusted for multiple-hypothesis testing). Clustered standard errors at the municipality level in parenthesis. Column (1) shows regression coefficient of the treatment for the whole sample (average effect). Columns (2) to (7) show coefficients of the treatment in the regression for each sub-sample. 
Table 46: Heterogeneous effects: First follow-up Tablet effect on Financial Performance (Self-Reported)

\begin{tabular}{|c|c|c|c|c|c|c|c|c|c|}
\hline & \multirow[b]{2}{*}{$\begin{array}{l}\text { Total } \\
(1)\end{array}$} & \multicolumn{4}{|c|}{ Interactions with SISBEN points quartiles } & \multicolumn{4}{|c|}{ Interactions with age quartiles } \\
\hline & & $\begin{array}{l}\text { Treat } \\
(2)\end{array}$ & $\begin{array}{c}\text { Treat*Q2 } \\
(3)\end{array}$ & $\begin{array}{c}\text { Treat*Q3 } \\
(4)\end{array}$ & $\begin{array}{c}\text { Treat*Q4 } \\
(5)\end{array}$ & $\begin{array}{l}\text { Treat } \\
(6)\end{array}$ & $\begin{array}{c}\text { Treat*Q2 } \\
(7)\end{array}$ & $\begin{array}{c}\text { Treat*Q3 } \\
(8)\end{array}$ & $\begin{array}{c}\text { Treat*Q4 } \\
(9)\end{array}$ \\
\hline \multicolumn{10}{|l|}{ Panel A: Probability of saving } \\
\hline Has formal or informal savings & $\begin{array}{c}0.146^{* * *} \\
(0.023)\end{array}$ & $\begin{array}{c}0.177^{* * *} \\
(0.033)\end{array}$ & $\begin{array}{l}-0.012 \\
(0.049)\end{array}$ & $\begin{array}{c}-0.097^{*} \\
(0.052)\end{array}$ & $\begin{array}{l}-0.030 \\
(0.047)\end{array}$ & $\begin{array}{c}0.060^{* *} \\
(0.030)\end{array}$ & $\begin{array}{c}0.132^{* * * *} \\
(0.043)\end{array}$ & $\begin{array}{c}0.148^{* * *} \\
(0.048)\end{array}$ & $\begin{array}{c}0.057 \\
(0.048)\end{array}$ \\
\hline Has formal savings & $\begin{array}{c}0.030^{* *} \\
(0.013)\end{array}$ & $\begin{array}{c}0.030 \\
(0.020)\end{array}$ & $\begin{array}{c}0.003 \\
(0.029)\end{array}$ & $\begin{array}{l}-0.006 \\
(0.029)\end{array}$ & $\begin{array}{c}0.006 \\
(0.034)\end{array}$ & $\begin{array}{l}-0.009 \\
(0.027)\end{array}$ & $\begin{array}{c}0.049 \\
(0.034)\end{array}$ & $\begin{array}{c}0.073^{* *} \\
(0.035)\end{array}$ & $\begin{array}{c}0.033 \\
(0.035)\end{array}$ \\
\hline Has informal savings & $\begin{array}{c}0.148^{* * *} \\
(0.022)\end{array}$ & $\begin{array}{c}0.188^{* * *} \\
(0.034)\end{array}$ & $\begin{array}{l}-0.000 \\
(0.050)\end{array}$ & $\begin{array}{c}-0.121^{* *} \\
(0.053)\end{array}$ & $\begin{array}{l}-0.054 \\
(0.053)\end{array}$ & $\begin{array}{c}0.103^{* * *} \\
(0.028)\end{array}$ & $\begin{array}{c}0.084^{* *} \\
(0.041)\end{array}$ & $\begin{array}{l}0.087^{*} \\
(0.051)\end{array}$ & $\begin{array}{c}0.006 \\
(0.048)\end{array}$ \\
\hline Has savings in a bank & $\begin{array}{c}0.029^{* * *} \\
(0.009)\end{array}$ & $\begin{array}{c}0.020 \\
(0.014)\end{array}$ & $\begin{array}{c}0.034 \\
(0.025)\end{array}$ & $\begin{array}{c}0.028 \\
(0.023)\end{array}$ & $\begin{array}{l}-0.028 \\
(0.025)\end{array}$ & $\begin{array}{c}0.010 \\
(0.020)\end{array}$ & $\begin{array}{c}0.037 \\
(0.033)\end{array}$ & $\begin{array}{c}0.036 \\
(0.026)\end{array}$ & $\begin{array}{c}0.001 \\
(0.025)\end{array}$ \\
\hline Has savings in a cooperative & $\begin{array}{c}0.017 \\
(0.011)\end{array}$ & $\begin{array}{c}0.015 \\
(0.017)\end{array}$ & $\begin{array}{l}-0.009 \\
(0.022)\end{array}$ & $\begin{array}{l}-0.011 \\
(0.019)\end{array}$ & $\begin{array}{l}0.026 \\
(0.021)\end{array}$ & $\begin{array}{l}-0.010 \\
(0.018)\end{array}$ & $\begin{array}{c}0.011 \\
(0.020)\end{array}$ & $\begin{array}{l}0.047^{*} \\
(0.026)\end{array}$ & $\begin{array}{l}0.045^{*} \\
(0.024)\end{array}$ \\
\hline Has savings in piggy bank & $\begin{array}{c}0.148^{* * *} \\
(0.022)\end{array}$ & $\begin{array}{c}0.194^{* * *} \\
(0.033)\end{array}$ & $\begin{array}{l}-0.006 \\
(0.050)\end{array}$ & $\begin{array}{c}-0.132^{* *} \\
(0.052)\end{array}$ & $\begin{array}{l}-0.061 \\
(0.052)\end{array}$ & $\begin{array}{c}0.106^{* * *} \\
(0.030)\end{array}$ & $\begin{array}{l}0.077^{*} \\
(0.040)\end{array}$ & $\begin{array}{l}0.085^{*} \\
(0.051)\end{array}$ & $\begin{array}{c}0.001 \\
(0.049)\end{array}$ \\
\hline \multicolumn{10}{|l|}{ Panel B: Tobit estimates for savings } \\
\hline Total formal and informal savings & $\begin{array}{c}0.516^{* * *} \\
(0.158)\end{array}$ & $\begin{array}{c}0.624^{* * *} \\
(0.214)\end{array}$ & $\begin{array}{l}-0.270 \\
(0.339)\end{array}$ & $\begin{array}{l}-0.108 \\
(0.378)\end{array}$ & $\begin{array}{l}-0.071 \\
(0.357)\end{array}$ & $\begin{array}{l}-0.026 \\
(0.258)\end{array}$ & $\begin{array}{c}1.246^{* * *} \\
(0.449)\end{array}$ & $\begin{array}{l}0.581^{*} \\
(0.341)\end{array}$ & $\begin{array}{c}0.325 \\
(0.315)\end{array}$ \\
\hline Total formal savings & $\begin{array}{l}1.244^{*} \\
(0.659)\end{array}$ & $\begin{array}{c}0.367 \\
(0.982)\end{array}$ & $\begin{array}{c}0.763 \\
(1.558)\end{array}$ & $\begin{array}{c}1.885 \\
(1.668)\end{array}$ & $\begin{array}{c}1.763 \\
(1.907)\end{array}$ & $\begin{array}{l}-0.327 \\
(1.445)\end{array}$ & $\begin{array}{c}2.473 \\
(1.702)\end{array}$ & $\begin{array}{l}3.149^{*} \\
(1.683)\end{array}$ & $\begin{array}{c}0.547 \\
(1.822)\end{array}$ \\
\hline Total informal savings & $\begin{array}{c}0.505 * * * \\
(0.161)\end{array}$ & $\begin{array}{c}0.661^{* * * *} \\
(0.248)\end{array}$ & $\begin{array}{l}-0.285 \\
(0.387)\end{array}$ & $\begin{array}{l}-0.259 \\
(0.441)\end{array}$ & $\begin{array}{l}-0.140 \\
(0.413)\end{array}$ & $\begin{array}{c}0.121 \\
(0.274)\end{array}$ & $\begin{array}{c}0.958^{* *} \\
(0.471)\end{array}$ & $\begin{array}{c}0.187 \\
(0.390)\end{array}$ & $\begin{array}{c}0.395 \\
(0.383)\end{array}$ \\
\hline Savings in a bank & $\begin{array}{c}3.214^{* * *} \\
(1.070)\end{array}$ & $\begin{array}{c}1.650 \\
(1.684)\end{array}$ & $\begin{array}{l}1.515 \\
(2.436)\end{array}$ & $\begin{array}{l}6.130^{*} \\
(3.339)\end{array}$ & $\begin{array}{c}0.684 \\
(3.063)\end{array}$ & $\begin{array}{c}0.033 \\
(2.356)\end{array}$ & $\begin{array}{c}4.862 \\
(3.410)\end{array}$ & $\begin{array}{l}6.503^{*} \\
(3.364)\end{array}$ & $\begin{array}{c}0.872 \\
(2.806)\end{array}$ \\
\hline Savings in a cooperative & $\begin{array}{c}0.860 \\
(2.338)\end{array}$ & $\begin{array}{l}-0.109 \\
(3.404)\end{array}$ & $\begin{array}{c}2.273 \\
(5.633)\end{array}$ & $\begin{array}{l}-0.009 \\
(4.947)\end{array}$ & $\begin{array}{c}2.864 \\
(4.957)\end{array}$ & $\begin{array}{l}-1.976 \\
(4.427)\end{array}$ & $\begin{array}{c}2.049 \\
(5.403)\end{array}$ & $\begin{array}{c}5.064 \\
(5.986)\end{array}$ & $\begin{array}{c}3.647 \\
(5.868)\end{array}$ \\
\hline Savings in piggy bank & $\begin{array}{c}0.464^{* * *} \\
(0.169)\end{array}$ & $\begin{array}{c}0.590^{* *} \\
(0.251)\end{array}$ & $\begin{array}{l}-0.238 \\
(0.390)\end{array}$ & $\begin{array}{l}-0.204 \\
(0.472)\end{array}$ & $\begin{array}{l}-0.103 \\
(0.405)\end{array}$ & $\begin{array}{c}0.054 \\
(0.294)\end{array}$ & $\begin{array}{c}1.000^{* *} \\
(0.473)\end{array}$ & $\begin{array}{c}0.243 \\
(0.423)\end{array}$ & $\begin{array}{c}0.405 \\
(0.393)\end{array}$ \\
\hline
\end{tabular}

Notes: $* * *$ significant at $1 \%, * *$ significant at $5 \%, *$ significant at $10 \%$ (based on $p$-values unadjusted for multiple-hypothesis testing). Clustered standard errors at the municipality level in parenthesis. Column (1) shows regression coefficient of the treatment for the whole sample (average effect). Columns (2) to (5) and (6) to (9) show coefficients of the regression that includes interaction terms of the treatment variable with SISBEN points and age, respectively. 
Table 47: Heterogeneous effects: Second follow-up Tablet effect on Financial Performance (Self-Reported)

\begin{tabular}{|c|c|c|c|c|c|c|c|}
\hline & \multirow[b]{2}{*}{$\begin{array}{c}\text { Total } \\
(1)\end{array}$} & \multicolumn{2}{|c|}{ Area } & \multicolumn{2}{|c|}{ Region } & \multicolumn{2}{|c|}{ Schooling } \\
\hline & & $\begin{array}{l}\text { Urban } \\
\quad(2)\end{array}$ & $\begin{array}{c}\text { Rural } \\
(3)\end{array}$ & $\begin{array}{c}\text { Caribe } \\
(4)\end{array}$ & $\begin{array}{c}\text { Pacifico } \\
(5)\end{array}$ & $\begin{array}{c}\text { Primary } \\
(6)\end{array}$ & $\begin{array}{c}\text { Secondary } \\
(7)\end{array}$ \\
\hline \multicolumn{8}{|l|}{ Panel A: Probability of saving } \\
\hline Has formal or informal savings & $\begin{array}{c}0.110^{* * *} \\
(0.018)\end{array}$ & $\begin{array}{c}0.105^{* * *} \\
(0.030)\end{array}$ & $\begin{array}{c}0.113^{* * *} \\
(0.023)\end{array}$ & $\begin{array}{c}0.126^{* * *} \\
(0.023)\end{array}$ & $\begin{array}{c}0.072^{* *} \\
(0.028)\end{array}$ & $\begin{array}{c}0.138^{* * *} \\
(0.025)\end{array}$ & $\begin{array}{c}0.081^{* * *} \\
(0.025)\end{array}$ \\
\hline Has formal savings & $\begin{array}{c}0.008 \\
(0.011)\end{array}$ & $\begin{array}{c}-0.003 \\
(0.016)\end{array}$ & $\begin{array}{c}0.012 \\
(0.019)\end{array}$ & $\begin{array}{c}0.015 \\
(0.011)\end{array}$ & $\begin{array}{c}-0.023 \\
(0.028)\end{array}$ & $\begin{array}{c}-0.007 \\
(0.017)\end{array}$ & $\begin{array}{c}0.018 \\
(0.017)\end{array}$ \\
\hline Has informal savings & $\begin{array}{c}0.108^{* * *} \\
(0.019)\end{array}$ & $\begin{array}{c}0.099^{* * *} \\
(0.030)\end{array}$ & $\begin{array}{c}0.118^{* * *} \\
(0.022)\end{array}$ & $\begin{array}{c}0.119^{* * *} \\
(0.024)\end{array}$ & $\begin{array}{c}0.090^{* * *} * \\
(0.030)\end{array}$ & $\begin{array}{c}0.147^{* * *} \\
(0.025)\end{array}$ & $\begin{array}{c}0.070^{* * *} \\
(0.023)\end{array}$ \\
\hline Has savings in a bank & $\begin{array}{c}-0.003 \\
(0.009)\end{array}$ & $\begin{array}{c}-0.011 \\
(0.012)\end{array}$ & $\begin{array}{c}0.001 \\
(0.015)\end{array}$ & $\begin{array}{c}0.001 \\
(0.010)\end{array}$ & $\begin{array}{c}-0.025 \\
(0.020)\end{array}$ & $\begin{array}{c}-0.003 \\
(0.014)\end{array}$ & $\begin{array}{l}-0.005 \\
(0.014)\end{array}$ \\
\hline Has savings in a cooperative & $\begin{array}{c}0.015^{*} \\
(0.008)\end{array}$ & $\begin{array}{c}0.008 \\
(0.008)\end{array}$ & $\begin{array}{c}0.016 \\
(0.014)\end{array}$ & $\begin{array}{c}0.016^{* *} \\
(0.007)\end{array}$ & $\begin{array}{c}0.005 \\
(0.024)\end{array}$ & $\begin{array}{c}0.003 \\
(0.009)\end{array}$ & $\begin{array}{c}0.024^{* *} \\
(0.011)\end{array}$ \\
\hline Has savings in piggy bank & $\begin{array}{c}0.104^{* * *} \\
(0.018)\end{array}$ & $\begin{array}{c}0.092^{* * *} \\
(0.029)\end{array}$ & $\begin{array}{c}0.116^{* * *} \\
(0.020)\end{array}$ & $\begin{array}{c}0.112^{* * *} \\
(0.023)\end{array}$ & $\begin{array}{c}0.091^{* * *} * \\
(0.031)\end{array}$ & $\begin{array}{c}0.139^{* * *} \\
(0.026)\end{array}$ & $\begin{array}{c}0.070^{* * *} \\
(0.024)\end{array}$ \\
\hline \multicolumn{8}{|l|}{ Panel B: Tobit estimates for savings } \\
\hline Total formal and informal savings & $\begin{array}{c}0.858^{* *} \\
(0.339)\end{array}$ & $\begin{array}{c}-0.410 \\
(1.136)\end{array}$ & $\begin{array}{c}1.489^{* *} \\
(0.700)\end{array}$ & $\begin{array}{c}1.287^{*} \\
(0.760)\end{array}$ & $\begin{array}{l}-0.252 \\
(0.932)\end{array}$ & $\begin{array}{c}1.357^{* *} \\
(0.647)\end{array}$ & $\begin{array}{c}0.102 \\
(0.838)\end{array}$ \\
\hline Total formal savings & $\begin{array}{c}0.990 \\
(1.205)\end{array}$ & $\begin{array}{l}-2.058 \\
(3.773)\end{array}$ & $\begin{array}{c}4.612 \\
(3.044)\end{array}$ & $\begin{array}{c}1.723 \\
(3.190)\end{array}$ & $\begin{array}{c}2.069 \\
(3.672)\end{array}$ & $\begin{array}{c}3.151 \\
(2.888)\end{array}$ & $\begin{array}{c}0.920 \\
(3.453)\end{array}$ \\
\hline Total informal savings & $\begin{array}{c}0.809^{* * *} \\
(0.267)\end{array}$ & $\begin{array}{c}-0.041 \\
(0.854)\end{array}$ & $\begin{array}{c}0.862 \\
(0.534)\end{array}$ & $\begin{array}{c}1.175^{* *} \\
(0.558)\end{array}$ & $\begin{array}{c}-0.503 \\
(0.725)\end{array}$ & $\begin{array}{c}0.789 \\
(0.568)\end{array}$ & $\begin{array}{c}0.206 \\
(0.600)\end{array}$ \\
\hline Savings in a bank & $\begin{array}{c}0.252 \\
(2.019)\end{array}$ & $\begin{array}{c}-0.489 \\
(0.479)\end{array}$ & $\begin{array}{c}0.523 \\
(0.387)\end{array}$ & $\begin{array}{c}0.076 \\
(0.312)\end{array}$ & $\begin{array}{c}0.152 \\
(0.526)\end{array}$ & $\begin{array}{c}0.558^{* *} \\
(0.241)\end{array}$ & $\begin{array}{c}-0.225 \\
(0.534)\end{array}$ \\
\hline Savings in a cooperative & $\begin{array}{c}4.288 \\
(3.598)\end{array}$ & $\begin{array}{c}0.136 \\
(0.431)\end{array}$ & $\begin{array}{c}0.296 \\
(0.328)\end{array}$ & $\begin{array}{l}-0.000 \\
(0.198)\end{array}$ & $\begin{array}{c}0.392 \\
(0.584)\end{array}$ & $\begin{array}{l}-0.033 \\
(0.284)\end{array}$ & $\begin{array}{c}0.774 \\
(0.494)\end{array}$ \\
\hline Savings in piggy bank & $\begin{array}{c}0.843^{* * *} \\
(0.274)\end{array}$ & $\begin{array}{l}-0.163 \\
(0.866)\end{array}$ & $\begin{array}{c}0.650 \\
(0.576)\end{array}$ & $\begin{array}{c}1.185^{* *} \\
(0.568)\end{array}$ & $\begin{array}{l}-0.720 \\
(0.599)\end{array}$ & $\begin{array}{c}0.599 \\
(0.593)\end{array}$ & $\begin{array}{c}0.141 \\
(0.680)\end{array}$ \\
\hline
\end{tabular}

Notes: $* * *$ significant at $1 \%, * *$ significant at $5 \%, *$ significant at $10 \%$ (based on $p$-values unadjusted for multiple-hypothesis testing). Clustered standard errors at the municipality level in parenthesis. Column (1) shows regression coefficient of the treatment for the whole sample (average effect). Columns (2) to (7) show coefficients of the treatment in the regression for each sub-sample. 
Table 48: Heterogeneous effects: Second follow-up Tablet effect on Financial Performance (Self-Reported)

\begin{tabular}{|c|c|c|c|c|c|c|c|c|c|}
\hline & \multirow[b]{2}{*}{$\begin{array}{c}\text { Total } \\
(1)\end{array}$} & \multicolumn{4}{|c|}{ Interactions with SISBEN points quartiles } & \multicolumn{4}{|c|}{ Interactions with age quartiles } \\
\hline & & $\begin{array}{l}\text { Treat } \\
(2)\end{array}$ & $\begin{array}{c}\text { Treat*Q2 } \\
(3)\end{array}$ & $\begin{array}{c}\text { Treat*Q3 } \\
\text { (4) }\end{array}$ & $\begin{array}{c}\text { Treat* }{ }^{*} 4 \\
(5)\end{array}$ & $\begin{array}{l}\text { Treat } \\
(6)\end{array}$ & $\begin{array}{c}\text { Treat*Q2 } \\
(7)\end{array}$ & $\begin{array}{c}\text { Treat*Q3 } \\
(8)\end{array}$ & $\begin{array}{c}\text { Treat*Q4 } \\
\text { (9) }\end{array}$ \\
\hline \multicolumn{10}{|l|}{ Panel A: Probability of saving } \\
\hline Has formal or informal savings & $\begin{array}{c}0.110^{* * *} \\
(0.018)\end{array}$ & $\begin{array}{c}0.085^{* *} \\
(0.039)\end{array}$ & $\begin{array}{c}0.081 \\
(0.053)\end{array}$ & $\begin{array}{c}-0.010 \\
(0.057)\end{array}$ & $\begin{array}{c}0.027 \\
(0.061)\end{array}$ & $\begin{array}{c}0.038 \\
(0.037)\end{array}$ & $\begin{array}{c}0.090^{*} \\
(0.053)\end{array}$ & $\begin{array}{c}0.115^{* *} \\
(0.051)\end{array}$ & $\begin{array}{c}0.080 \\
(0.059)\end{array}$ \\
\hline Has formal savings & $\begin{array}{c}0.008 \\
(0.011)\end{array}$ & $\begin{array}{c}0.023 \\
(0.025)\end{array}$ & $\begin{array}{l}-0.020 \\
(0.038)\end{array}$ & $\begin{array}{l}-0.026 \\
(0.035)\end{array}$ & $\begin{array}{c}-0.021 \\
(0.036)\end{array}$ & $\begin{array}{c}0.015 \\
(0.021)\end{array}$ & $\begin{array}{c}0.047 \\
(0.034)\end{array}$ & $\begin{array}{l}-0.038 \\
(0.033)\end{array}$ & $\begin{array}{l}-0.035 \\
(0.030)\end{array}$ \\
\hline Has informal savings & $\begin{array}{c}0.108^{* * *} \\
(0.019)\end{array}$ & $\begin{array}{c}0.084^{* *} \\
(0.038)\end{array}$ & $\begin{array}{c}0.090^{*} \\
(0.047)\end{array}$ & $\begin{array}{c}-0.010 \\
(0.056)\end{array}$ & $\begin{array}{c}0.019 \\
(0.060)\end{array}$ & $\begin{array}{c}0.041 \\
(0.038)\end{array}$ & $\begin{array}{c}0.065 \\
(0.053)\end{array}$ & $\begin{array}{c}0.114^{* *} \\
(0.055)\end{array}$ & $\begin{array}{c}0.090 \\
(0.060)\end{array}$ \\
\hline Has savings in a bank & $\begin{array}{c}-0.003 \\
(0.009)\end{array}$ & $\begin{array}{c}0.022 \\
(0.021)\end{array}$ & $\begin{array}{l}-0.029 \\
(0.030)\end{array}$ & $\begin{array}{c}-0.033 \\
(0.030)\end{array}$ & $\begin{array}{l}-0.049 \\
(0.030)\end{array}$ & $\begin{array}{c}-0.001 \\
(0.018)\end{array}$ & $\begin{array}{c}0.027 \\
(0.026)\end{array}$ & $\begin{array}{l}-0.018 \\
(0.025)\end{array}$ & $\begin{array}{c}-0.016 \\
(0.024)\end{array}$ \\
\hline Has savings in a cooperative & $\begin{array}{c}0.015^{*} \\
(0.008)\end{array}$ & $\begin{array}{c}0.012 \\
(0.015)\end{array}$ & $\begin{array}{l}-0.006 \\
(0.019)\end{array}$ & $\begin{array}{c}0.004 \\
(0.022)\end{array}$ & $\begin{array}{c}0.015 \\
(0.022)\end{array}$ & $\begin{array}{l}0.024^{*} \\
(0.014)\end{array}$ & $\begin{array}{c}0.008 \\
(0.021)\end{array}$ & $\begin{array}{l}-0.023 \\
(0.026)\end{array}$ & $\begin{array}{l}-0.019 \\
(0.022)\end{array}$ \\
\hline Has savings in piggy bank & $\begin{array}{c}0.104^{* * *} \\
(0.018)\end{array}$ & $\begin{array}{c}0.080 * * \\
(0.037)\end{array}$ & $\begin{array}{c}0.093^{*} \\
(0.048)\end{array}$ & $\begin{array}{l}-0.013 \\
(0.055)\end{array}$ & $\begin{array}{c}0.016 \\
(0.060)\end{array}$ & $\begin{array}{c}0.040 \\
(0.036)\end{array}$ & $\begin{array}{c}0.071 \\
(0.052)\end{array}$ & $\begin{array}{l}0.100^{*} \\
(0.052)\end{array}$ & $\begin{array}{c}0.082 \\
(0.058)\end{array}$ \\
\hline \multicolumn{10}{|l|}{ Panel B: Tobit estimates for savings } \\
\hline Total formal and informal savings & $\begin{array}{c}0.858^{* *} \\
(0.339)\end{array}$ & $\begin{array}{c}0.850 \\
(0.585)\end{array}$ & $\begin{array}{c}0.743 \\
(0.815)\end{array}$ & $\begin{array}{l}-0.179 \\
(0.912)\end{array}$ & $\begin{array}{l}-0.442 \\
(0.929)\end{array}$ & $\begin{array}{c}0.162 \\
(0.532)\end{array}$ & $\begin{array}{c}0.725 \\
(0.851)\end{array}$ & $\begin{array}{l}1.131^{*} \\
(0.682)\end{array}$ & $\begin{array}{c}0.976 \\
(0.896)\end{array}$ \\
\hline Total formal savings & $\begin{array}{c}0.990 \\
(1.205)\end{array}$ & $\begin{array}{c}2.649 \\
(2.399)\end{array}$ & $\begin{array}{c}-0.147 \\
(4.698)\end{array}$ & $\begin{array}{l}-4.784 \\
(3.367)\end{array}$ & $\begin{array}{l}-1.799 \\
(3.440)\end{array}$ & $\begin{array}{c}1.324 \\
(2.715)\end{array}$ & $\begin{array}{c}3.356 \\
(3.875)\end{array}$ & $\begin{array}{l}-1.498 \\
(3.656)\end{array}$ & $\begin{array}{l}-3.875 \\
(4.213)\end{array}$ \\
\hline Total informal savings & $\begin{array}{c}0.809^{* * *} \\
(0.267)\end{array}$ & $\begin{array}{c}0.525 \\
(0.433)\end{array}$ & $\begin{array}{l}0.942^{*} \\
(0.535)\end{array}$ & $\begin{array}{c}0.330 \\
(0.699)\end{array}$ & $\begin{array}{c}-0.013 \\
(0.620)\end{array}$ & $\begin{array}{c}0.326 \\
(0.426)\end{array}$ & $\begin{array}{c}-0.075 \\
(0.576)\end{array}$ & $\begin{array}{l}0.979^{*} \\
(0.578)\end{array}$ & $\begin{array}{l}1.237^{*} \\
(0.733)\end{array}$ \\
\hline Savings in a bank & $\begin{array}{c}0.252 \\
(2.019)\end{array}$ & $\begin{array}{c}6.693 \\
(4.131)\end{array}$ & $\begin{array}{l}-4.915 \\
(7.262)\end{array}$ & $\begin{array}{c}-11.721^{* *} \\
(5.811)\end{array}$ & $\begin{array}{c}-10.284 \\
(7.062)\end{array}$ & $\begin{array}{c}0.248 \\
(4.300)\end{array}$ & $\begin{array}{c}5.682 \\
(6.013)\end{array}$ & $\begin{array}{l}-1.265 \\
(4.957)\end{array}$ & $\begin{array}{l}-5.582 \\
(6.298)\end{array}$ \\
\hline Savings in a cooperative & $\begin{array}{c}4.288 \\
(3.598)\end{array}$ & $\begin{array}{c}1.052 \\
(5.420)\end{array}$ & $\begin{array}{c}14.351 \\
(10.859)\end{array}$ & $\begin{array}{l}-1.477 \\
(8.368)\end{array}$ & $\begin{array}{c}6.570 \\
(7.010)\end{array}$ & $\begin{array}{c}5.877 \\
(7.386)\end{array}$ & $\begin{array}{c}2.668 \\
(9.562)\end{array}$ & $\begin{array}{c}-2.588 \\
(10.701)\end{array}$ & $\begin{array}{c}-6.657 \\
(10.993)\end{array}$ \\
\hline Savings in piggy bank & $\begin{array}{c}0.843^{* * *} \\
(0.274)\end{array}$ & $\begin{array}{c}0.362 \\
(0.414)\end{array}$ & $\begin{array}{c}1.549^{* * *} \\
(0.539)\end{array}$ & $\begin{array}{c}0.436 \\
(0.678)\end{array}$ & $\begin{array}{c}0.083 \\
(0.626)\end{array}$ & $\begin{array}{c}0.428 \\
(0.439)\end{array}$ & $\begin{array}{l}-0.081 \\
(0.637)\end{array}$ & $\begin{array}{c}0.823 \\
(0.622)\end{array}$ & $\begin{array}{c}1.084 \\
(0.731)\end{array}$ \\
\hline
\end{tabular}

Notes: $* * *$ significant at $1 \%, * *$ significant at $5 \%, *$ significant at $10 \%$ (based on $p$-values unadjusted for multiple-hypothesis testing). Clustered standard errors at the municipality level in parenthesis. Column (1) shows regression coefficient of the treatment for the whole sample (average effect). Columns (2) to (5) and (6) to (9) show coefficients of the regression that includes interaction terms of the treatment variable with SISBEN points and age, respectively. 
Table 49: Heterogeneous effects: Third follow-up Tablet effect on Financial Performance (Self-Reported)

\begin{tabular}{|c|c|c|c|c|c|c|c|}
\hline & \multirow[b]{2}{*}{$\begin{array}{c}\text { Total } \\
(1)\end{array}$} & \multicolumn{2}{|c|}{ Area } & \multicolumn{2}{|c|}{ Region } & \multicolumn{2}{|c|}{ Schooling } \\
\hline & & $\begin{array}{c}\text { Urban } \\
(2)\end{array}$ & $\begin{array}{c}\text { Rural } \\
(3)\end{array}$ & $\begin{array}{c}\text { Caribe } \\
(4)\end{array}$ & $\begin{array}{c}\text { Pacifico } \\
(5)\end{array}$ & $\begin{array}{c}\text { Primary } \\
\quad(6)\end{array}$ & $\begin{array}{c}\text { Secondary } \\
(7)\end{array}$ \\
\hline \multicolumn{8}{|l|}{ Panel A: Probability of saving } \\
\hline Has formal or informal savings & $\begin{array}{c}0.115^{* * *} \\
(0.022)\end{array}$ & $\begin{array}{c}0.094^{* * *} \\
(0.026)\end{array}$ & $\begin{array}{c}0.146^{* * *} \\
(0.032)\end{array}$ & $\begin{array}{c}0.131^{* * *} \\
(0.026)\end{array}$ & $\begin{array}{c}0.085^{*} \\
(0.047)\end{array}$ & $\begin{array}{c}0.095^{* * *} \\
(0.032)\end{array}$ & $\begin{array}{c}0.132^{* * *} \\
(0.023)\end{array}$ \\
\hline Has formal savings & $\begin{array}{c}0.026^{*} \\
(0.014)\end{array}$ & $\begin{array}{c}0.011 \\
(0.017)\end{array}$ & $\begin{array}{c}0.043^{* *} \\
(0.019)\end{array}$ & $\begin{array}{c}0.029^{* *} \\
(0.014)\end{array}$ & $\begin{array}{c}0.011 \\
(0.032)\end{array}$ & $\begin{array}{c}-0.001 \\
(0.021)\end{array}$ & $\begin{array}{c}0.047^{* *} \\
(0.019)\end{array}$ \\
\hline Has informal savings & $\begin{array}{c}0.103^{* * *} \\
(0.021)\end{array}$ & $\begin{array}{c}0.083^{* * *} \\
(0.025)\end{array}$ & $\begin{array}{c}0.130^{* * *} \\
(0.032)\end{array}$ & $\begin{array}{c}0.107^{* * *} \\
(0.024)\end{array}$ & $\begin{array}{c}0.095^{* *} \\
(0.045)\end{array}$ & $\begin{array}{c}0.111^{* * *} \\
(0.031)\end{array}$ & $\begin{array}{c}0.090^{* * *} \\
(0.026)\end{array}$ \\
\hline Has savings in a bank & $\begin{array}{c}0.010 \\
(0.012)\end{array}$ & $\begin{array}{l}-0.011 \\
(0.016)\end{array}$ & $\begin{array}{c}0.038 * * \\
(0.017)\end{array}$ & $\begin{array}{c}0.018 \\
(0.013)\end{array}$ & $\begin{array}{l}-0.014 \\
(0.025)\end{array}$ & $\begin{array}{c}0.004 \\
(0.015)\end{array}$ & $\begin{array}{c}0.016 \\
(0.017)\end{array}$ \\
\hline Has savings in a cooperative & $\begin{array}{c}0.022^{* * *} \\
(0.008)\end{array}$ & $\begin{array}{c}0.030^{* * *} \\
(0.011)\end{array}$ & $\begin{array}{c}0.011 \\
(0.011)\end{array}$ & $\begin{array}{c}0.019 * * \\
(0.009)\end{array}$ & $\begin{array}{c}0.024 \\
(0.016)\end{array}$ & $\begin{array}{c}0.003 \\
(0.010)\end{array}$ & $\begin{array}{c}0.037^{* * *} \\
(0.011)\end{array}$ \\
\hline Has savings in piggy bank & $\begin{array}{c}0.094^{* * *} \\
(0.017)\end{array}$ & $\begin{array}{c}0.077^{* * *} \\
(0.024)\end{array}$ & $\begin{array}{c}0.123^{* * *} \\
(0.030)\end{array}$ & $\begin{array}{c}0.104^{* * *} \\
(0.019)\end{array}$ & $\begin{array}{c}0.087^{* *} \\
(0.040)\end{array}$ & $\begin{array}{c}0.101^{* * *} \\
(0.027)\end{array}$ & $\begin{array}{c}0.086^{* * *} \\
(0.024)\end{array}$ \\
\hline \multicolumn{8}{|l|}{ Panel B: Tobit estimates for savings } \\
\hline Total formal and informal savings & $\begin{array}{c}0.907^{* * * *} \\
(0.283)\end{array}$ & $\begin{array}{c}0.694 \\
(0.634)\end{array}$ & $\begin{array}{c}1.927^{* *} \\
(0.836)\end{array}$ & $\begin{array}{c}1.078^{*} \\
(0.651)\end{array}$ & $\begin{array}{c}1.844 \\
(1.195)\end{array}$ & $\begin{array}{c}1.779^{* * *} \\
(0.676)\end{array}$ & $\begin{array}{c}0.786 \\
(0.765)\end{array}$ \\
\hline Total formal savings & $\begin{array}{c}1.534 \\
(1.002)\end{array}$ & $\begin{array}{l}-0.256 \\
(2.990)\end{array}$ & $\begin{array}{c}2.767 \\
(2.765)\end{array}$ & $\begin{array}{c}0.213 \\
(2.635)\end{array}$ & $\begin{array}{c}2.192 \\
(3.176)\end{array}$ & $\begin{array}{c}1.426 \\
(3.388)\end{array}$ & $\begin{array}{c}1.978 \\
(2.286)\end{array}$ \\
\hline Total informal savings & $\begin{array}{c}1.040^{* * *} \\
(0.250)\end{array}$ & $\begin{array}{c}0.950 \\
(0.613)\end{array}$ & $\begin{array}{c}1.938^{* * *} \\
(0.716)\end{array}$ & $\begin{array}{c}1.284^{* *} \\
(0.594)\end{array}$ & $\begin{array}{c}2.097^{* *} \\
(0.997)\end{array}$ & $\begin{array}{c}1.905^{* * *} \\
(0.533)\end{array}$ & $\begin{array}{c}1.062 \\
(0.843)\end{array}$ \\
\hline Savings in a bank & $\begin{array}{c}1.033 \\
(1.272)\end{array}$ & $\begin{array}{c}-0.703^{*} \\
(0.409)\end{array}$ & $\begin{array}{c}0.517 \\
(0.324)\end{array}$ & $\begin{array}{c}-0.141 \\
(0.260)\end{array}$ & $\begin{array}{c}0.289 \\
(0.454)\end{array}$ & $\begin{array}{c}0.229 \\
(0.270)\end{array}$ & $\begin{array}{c}-0.043 \\
(0.387)\end{array}$ \\
\hline Savings in a cooperative & $\begin{array}{c}7.509 * * \\
(3.097)\end{array}$ & $\begin{array}{c}0.922^{*} \\
(0.539)\end{array}$ & $\begin{array}{c}0.252 \\
(0.495)\end{array}$ & $\begin{array}{l}-0.111 \\
(0.249)\end{array}$ & $\begin{array}{c}0.771 \\
(0.806)\end{array}$ & $\begin{array}{c}0.329 \\
(0.614)\end{array}$ & $\begin{array}{c}0.305 \\
(0.479)\end{array}$ \\
\hline Savings in piggy bank & $\begin{array}{c}0.788^{* * *} * \\
(0.158)\end{array}$ & $\begin{array}{c}0.520 \\
(0.445)\end{array}$ & $\begin{array}{c}1.437^{* * *} \\
(0.477)\end{array}$ & $\begin{array}{c}1.329 * * * \\
(0.448)\end{array}$ & $\begin{array}{c}0.801 \\
(0.563)\end{array}$ & $\begin{array}{c}1.372^{* * *} \\
(0.435)\end{array}$ & $\begin{array}{c}0.519 \\
(0.483)\end{array}$ \\
\hline
\end{tabular}

Notes: $* * *$ significant at $1 \%, * *$ significant at $5 \%, *$ significant at $10 \%$ (based on $p$-values unadjusted for multiple-hypothesis testing). Clustered standard errors at the municipality level in parenthesis. Column (1) shows regression coefficient of the treatment for the whole sample (average effect). Columns (2) to (7) show coefficients of the treatment in the regression for each sub-sample. 
Table 50: Heterogeneous effects: Third follow-up Tablet effect on Financial Performance (Self-Reported)

\begin{tabular}{|c|c|c|c|c|c|c|c|c|c|}
\hline & \multirow[b]{2}{*}{$\begin{array}{l}\text { Total } \\
(1)\end{array}$} & \multicolumn{4}{|c|}{ Interactions with SISBEN points quartiles } & \multicolumn{4}{|c|}{ Interactions with age quartiles } \\
\hline & & $\begin{array}{c}\text { Treat } \\
(2)\end{array}$ & $\begin{array}{c}\text { Treat* }{ }^{*} 2 \\
(3)\end{array}$ & $\begin{array}{c}\text { Treat*Q33 } \\
(4)\end{array}$ & $\begin{array}{c}\text { Treat*Q44 } \\
(5)\end{array}$ & $\begin{array}{l}\text { Treat } \\
(6)\end{array}$ & $\begin{array}{c}\text { Treat* }{ }^{*} 2 \\
(7)\end{array}$ & $\begin{array}{c}\text { Treat*Q3 } \\
(8)\end{array}$ & $\begin{array}{c}\text { Treat*Q4 } \\
(9)\end{array}$ \\
\hline \multicolumn{10}{|l|}{ Panel A: Probability of saving } \\
\hline Has formal or informal savings & $\begin{array}{c}0.115^{* * *} \\
(0.022)\end{array}$ & $\begin{array}{c}0.135^{* * *} \\
(0.048)\end{array}$ & $\begin{array}{l}-0.010 \\
(0.055)\end{array}$ & $\begin{array}{l}-0.008 \\
(0.060)\end{array}$ & $\begin{array}{c}-0.059 \\
(0.056)\end{array}$ & $\begin{array}{c}0.104^{* * *} \\
(0.039)\end{array}$ & $\begin{array}{c}0.056 \\
(0.062)\end{array}$ & $\begin{array}{c}0.000 \\
(0.053)\end{array}$ & $\begin{array}{l}-0.008 \\
(0.056)\end{array}$ \\
\hline Has formal savings & $\begin{array}{c}0.026^{*} \\
(0.014)\end{array}$ & $\begin{array}{c}0.021 \\
(0.029)\end{array}$ & $\begin{array}{c}0.011 \\
(0.037)\end{array}$ & $\begin{array}{c}-0.009 \\
(0.042)\end{array}$ & $\begin{array}{c}0.015 \\
(0.037)\end{array}$ & $\begin{array}{c}0.030 \\
(0.031)\end{array}$ & $\begin{array}{c}0.032 \\
(0.039)\end{array}$ & $\begin{array}{c}-0.032 \\
(0.038)\end{array}$ & $\begin{array}{l}-0.015 \\
(0.037)\end{array}$ \\
\hline Has informal savings & $\begin{array}{c}0.103^{* * *} \\
(0.021)\end{array}$ & $\begin{array}{c}0.122^{* * *} \\
(0.044)\end{array}$ & $\begin{array}{c}-0.011 \\
(0.052)\end{array}$ & $\begin{array}{c}0.005 \\
(0.057)\end{array}$ & $\begin{array}{l}-0.070 \\
(0.052)\end{array}$ & $\begin{array}{c}0.086^{* *} \\
(0.040)\end{array}$ & $\begin{array}{c}0.045 \\
(0.063)\end{array}$ & $\begin{array}{c}0.009 \\
(0.054)\end{array}$ & $\begin{array}{c}0.012 \\
(0.061)\end{array}$ \\
\hline Has savings in a bank & $\begin{array}{c}0.010 \\
(0.012)\end{array}$ & $\begin{array}{c}0.016 \\
(0.025)\end{array}$ & $\begin{array}{c}0.014 \\
(0.032)\end{array}$ & $\begin{array}{l}-0.030 \\
(0.032)\end{array}$ & $\begin{array}{l}-0.004 \\
(0.032)\end{array}$ & $\begin{array}{c}0.002 \\
(0.026)\end{array}$ & $\begin{array}{c}0.014 \\
(0.036)\end{array}$ & $\begin{array}{c}0.008 \\
(0.033)\end{array}$ & $\begin{array}{c}0.008 \\
(0.033)\end{array}$ \\
\hline Has savings in a cooperative & $\begin{array}{c}0.022^{* * *} \\
(0.008)\end{array}$ & $\begin{array}{c}0.001 \\
(0.014)\end{array}$ & $\begin{array}{c}0.015 \\
(0.026)\end{array}$ & $\begin{array}{c}0.040 \\
(0.026)\end{array}$ & $\begin{array}{c}0.029 \\
(0.023)\end{array}$ & $\begin{array}{c}0.035^{*} \\
(0.018)\end{array}$ & $\begin{array}{c}0.006 \\
(0.025)\end{array}$ & $\begin{array}{c}-0.043^{*} \\
(0.024)\end{array}$ & $\begin{array}{l}-0.012 \\
(0.025)\end{array}$ \\
\hline Has savings in piggy bank & $\begin{array}{c}0.094^{* * *} \\
(0.017)\end{array}$ & $\begin{array}{c}0.106^{* * *} \\
(0.038)\end{array}$ & $\begin{array}{c}0.009 \\
(0.052)\end{array}$ & $\begin{array}{c}0.009 \\
(0.055)\end{array}$ & $\begin{array}{l}-0.069 \\
(0.049)\end{array}$ & $\begin{array}{c}0.049 \\
(0.039)\end{array}$ & $\begin{array}{c}0.094 \\
(0.062)\end{array}$ & $\begin{array}{c}0.041 \\
(0.059)\end{array}$ & $\begin{array}{c}0.045 \\
(0.057)\end{array}$ \\
\hline \multicolumn{10}{|l|}{ Panel B: Tobit estimates for savings } \\
\hline Total formal and informal savings & $\begin{array}{c}0.907^{* * *} \\
(0.283)\end{array}$ & $\begin{array}{c}1.352^{* *} \\
(0.664)\end{array}$ & $\begin{array}{l}-0.962 \\
(0.773)\end{array}$ & $\begin{array}{l}-0.584 \\
(0.795)\end{array}$ & $\begin{array}{l}-0.362 \\
(0.732)\end{array}$ & $\begin{array}{c}0.499 \\
(0.431)\end{array}$ & $\begin{array}{c}0.943 \\
(0.629)\end{array}$ & $\begin{array}{c}0.263 \\
(0.560)\end{array}$ & $\begin{array}{c}0.443 \\
(0.540)\end{array}$ \\
\hline Total formal savings & $\begin{array}{c}1.534 \\
(1.002)\end{array}$ & $\begin{array}{c}1.690 \\
(2.258)\end{array}$ & $\begin{array}{c}0.502 \\
(2.953)\end{array}$ & $\begin{array}{c}-1.500 \\
(3.011)\end{array}$ & $\begin{array}{c}0.712 \\
(3.072)\end{array}$ & $\begin{array}{c}1.092 \\
(1.883)\end{array}$ & $\begin{array}{c}3.761 \\
(2.454)\end{array}$ & $\begin{array}{l}-1.720 \\
(2.448)\end{array}$ & $\begin{array}{l}-0.502 \\
(2.662)\end{array}$ \\
\hline Total informal savings & $\begin{array}{c}1.040^{* * *} \\
(0.250)\end{array}$ & $\begin{array}{c}1.519^{* * * *} \\
(0.555)\end{array}$ & $\begin{array}{c}-1.132 * \\
(0.593)\end{array}$ & $\begin{array}{l}-0.194 \\
(0.636)\end{array}$ & $\begin{array}{l}-0.694 \\
(0.642)\end{array}$ & $\begin{array}{l}0.692^{*} \\
(0.421)\end{array}$ & $\begin{array}{c}0.308 \\
(0.647)\end{array}$ & $\begin{array}{c}0.439 \\
(0.605)\end{array}$ & $\begin{array}{c}0.668 \\
(0.567)\end{array}$ \\
\hline Savings in a bank & $\begin{array}{c}1.033 \\
(1.272)\end{array}$ & $\begin{array}{c}2.309 \\
(2.444)\end{array}$ & $\begin{array}{c}1.485 \\
(3.810)\end{array}$ & $\begin{array}{l}-4.466 \\
(3.211)\end{array}$ & $\begin{array}{l}-0.884 \\
(3.849)\end{array}$ & $\begin{array}{l}-0.255 \\
(2.682)\end{array}$ & $\begin{array}{c}3.470 \\
(3.687)\end{array}$ & $\begin{array}{c}0.755 \\
(3.673)\end{array}$ & $\begin{array}{c}0.614 \\
(3.665)\end{array}$ \\
\hline Savings in a cooperative & $\begin{array}{l}7.509 * * \\
(3.097)\end{array}$ & $\begin{array}{c}2.007 \\
(8.212)\end{array}$ & $\begin{array}{c}3.338 \\
(11.734)\end{array}$ & $\begin{array}{c}10.318 \\
(11.349)\end{array}$ & $\begin{array}{c}5.157 \\
(11.413)\end{array}$ & $\begin{array}{c}8.792 \\
(6.415)\end{array}$ & $\begin{array}{c}6.439 \\
(8.680)\end{array}$ & $\begin{array}{r}-11.601 \\
(8.890)\end{array}$ & $\begin{array}{c}-0.527 \\
(10.186)\end{array}$ \\
\hline Savings in piggy bank & $\begin{array}{c}0.788^{* * *} \\
(0.158)\end{array}$ & $\begin{array}{c}1.018^{* * *} \\
(0.347)\end{array}$ & $\begin{array}{c}-0.331 \\
(0.457)\end{array}$ & $\begin{array}{l}-0.130 \\
(0.454)\end{array}$ & $\begin{array}{c}-0.544 \\
(0.422)\end{array}$ & $\begin{array}{c}0.247 \\
(0.289)\end{array}$ & $\begin{array}{c}0.863^{*} \\
(0.470)\end{array}$ & $\begin{array}{c}0.425 \\
(0.497)\end{array}$ & $\begin{array}{c}0.901^{* *} \\
(0.448)\end{array}$ \\
\hline
\end{tabular}

Notes: $* * *$ significant at $1 \%, * *$ significant at $5 \%, *$ significant at $10 \%$ (based on $p$-values unadjusted for multiple-hypothesis testing). Clustered standard errors at the municipality level in parenthesis. Column (1) shows regression coefficient of the treatment for the whole sample (average effect). Columns (2) to (5) and (6) to (9) show coefficients of the regression that includes interaction terms of the treatment variable with SISBEN points and age, respectively. 
Table 51: Heterogeneous effects: Impact of LISTA on Financial Performance - Administrative Data

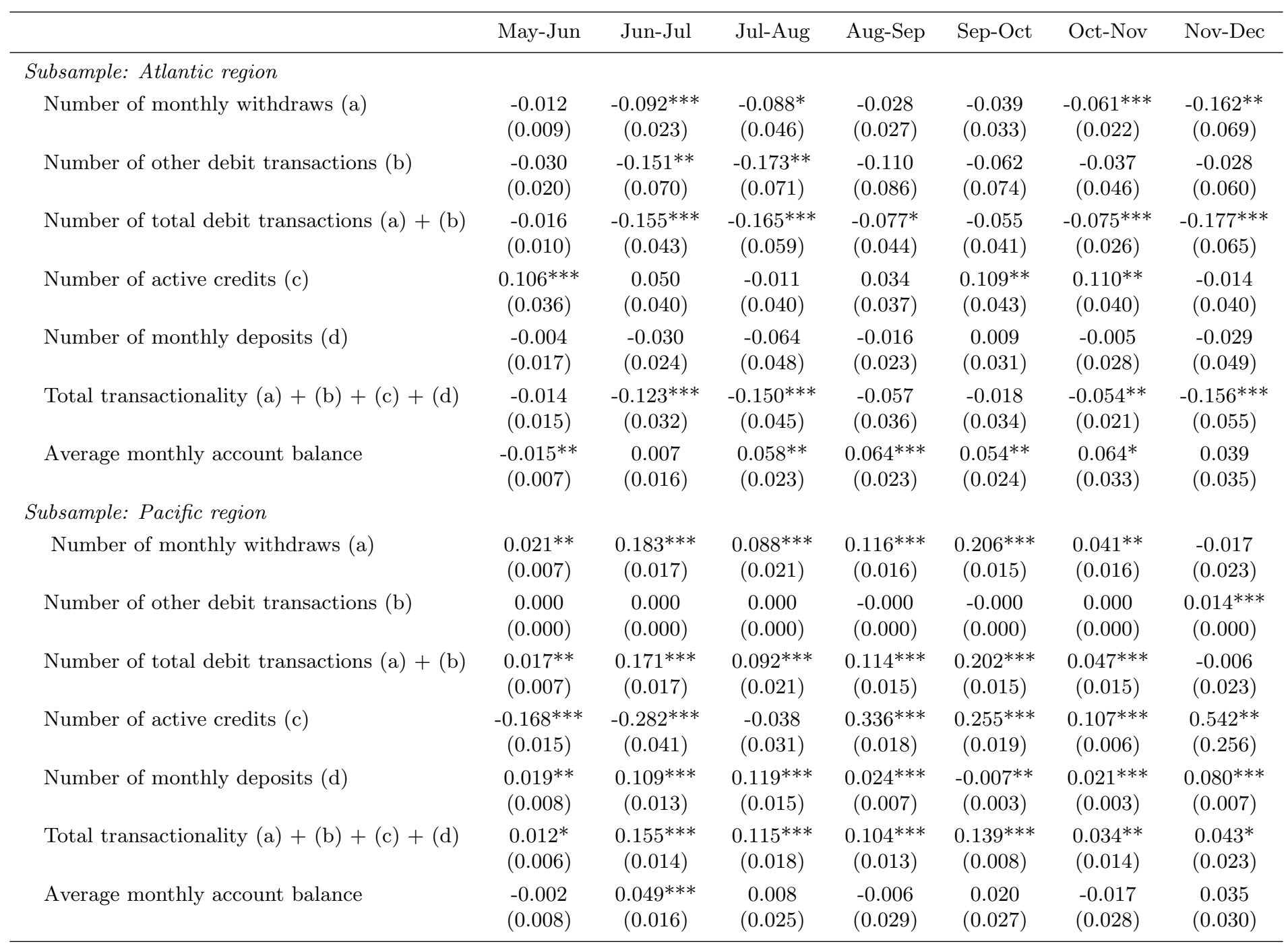

Note: Average savings are standardized using the mean and the variance from January 2014. Controls include: randomization blocks, account is from Banco Agrario, two-month moving average savings up to April 2015, number of financial institutions in the district, and a set of socioeconomic covariates at the municipal level. Clustered standard errors in parenthesis. ${ }^{*} \mathrm{p}<.1,{ }^{* *} \mathrm{p}<.05,{ }^{* * *} \mathrm{p}<.01$. 
Table 52: Heterogeneous effects: Second follow-up Tablet (Pooled Treatment) effect on Psychosocial Indicators

\begin{tabular}{lccccccc}
\hline & \multicolumn{3}{c}{ Area } & \multicolumn{2}{c}{ Region } & \multicolumn{3}{c}{ Schooling } \\
& Total & Urban & Rural & Caribe & Pacifico & Primary & Secondary \\
& $(1)$ & $(2)$ & $(3)$ & $(4)$ & $(5)$ & $(6)$ & $(7)$ \\
\hline Optimism & $0.095^{* *}$ & $0.158^{* *}$ & 0.044 & $0.128^{* *}$ & 0.071 & $0.146^{* *}$ & 0.055 \\
& $(0.043)$ & $(0.060)$ & $(0.067)$ & $(0.050)$ & $(0.068)$ & $(0.067)$ & $(0.054)$ \\
Pessimism & $-0.119^{* * *}$ & -0.075 & $-0.170^{* *}$ & $-0.093^{*}$ & $-0.242^{* *}$ & $-0.169^{* *}$ & -0.065 \\
& $(0.044)$ & $(0.055)$ & $(0.068)$ & $(0.047)$ & $(0.086)$ & $(0.065)$ & $(0.048)$ \\
People trust & -0.013 & 0.000 & $-0.027^{* *}$ & -0.003 & $-0.036^{*}$ & -0.010 & -0.013 \\
& $(0.009)$ & $(0.012)$ & $(0.013)$ & $(0.010)$ & $(0.019)$ & $(0.014)$ & $(0.013)$ \\
More trustworthy of other people & $0.080^{*}$ & 0.100 & 0.064 & 0.094 & 0.081 & 0.082 & 0.076 \\
& $(0.044)$ & $(0.062)$ & $(0.060)$ & $(0.059)$ & $(0.058)$ & $(0.057)$ & $(0.052)$ \\
Interested in savings program & 0.055 & 0.101 & -0.012 & 0.091 & -0.063 & 0.056 & 0.047 \\
& $(0.055)$ & $(0.074)$ & $(0.059)$ & $(0.071)$ & $(0.072)$ & $(0.066)$ & $(0.070)$ \\
There are lots of ways around & 0.025 & -0.010 & 0.068 & 0.001 & 0.083 & 0.064 & -0.016 \\
any problem that I am facing now & $(0.059)$ & $(0.060)$ & $(0.091)$ & $(0.061)$ & $(0.122)$ & $(0.077)$ & $(0.055)$ \\
Is meeting her goals & $0.088^{*}$ & 0.009 & $0.153^{* *}$ & 0.072 & 0.123 & $0.147^{*}$ & 0.034 \\
Self-efficacy & $(0.052)$ & $(0.059)$ & $(0.074)$ & $(0.055)$ & $(0.106)$ & $(0.080)$ & $(0.052)$ \\
Future orientation & & & & & & & \\
Social capital & & & & & & & \\
\end{tabular}

Notes: $* * *$ significant at $1 \%, * *$ significant at $5 \%, *$ significant at $10 \%$ (based on $p$-values unadjusted for multiple-hypothesis testing). Clustered standard errors at the municipality level in parenthesis. Column (1) shows regression coefficient of the treatment for the whole sample (average effect). Columns (2) to (7) show coefficients of the treatment in the regression for each sub-sample. 
Table 53: Heterogeneous effects: Second follow-up Tablet (Pooled Treatment) effect on Psychosocial Indicators

\begin{tabular}{|c|c|c|c|c|c|c|c|c|c|}
\hline & \multirow[b]{2}{*}{$\begin{array}{c}\text { Total } \\
(1)\end{array}$} & \multicolumn{4}{|c|}{ Interactions with SISBEN points quartiles } & \multicolumn{4}{|c|}{ Interactions with age quartiles } \\
\hline & & $\begin{array}{l}\text { Treat } \\
(2)\end{array}$ & $\begin{array}{c}\text { Treat*Q2 } \\
\text { (3) }\end{array}$ & $\begin{array}{c}\text { Treat*Q3 } \\
\text { (4) }\end{array}$ & $\begin{array}{c}\text { Treat* }{ }^{*} 4 \\
(5)\end{array}$ & $\begin{array}{l}\text { Treat } \\
(6)\end{array}$ & $\begin{array}{c}\text { Treat*Q2 } \\
(7)\end{array}$ & $\begin{array}{c}\text { Treat*Q3 } \\
\text { (8) }\end{array}$ & $\begin{array}{c}\text { Treat*Q4 } \\
\text { (9) }\end{array}$ \\
\hline Optimism & $\begin{array}{c}0.095^{* *} \\
(0.043)\end{array}$ & $\begin{array}{c}0.036 \\
(0.066)\end{array}$ & $\begin{array}{l}-0.016 \\
(0.097)\end{array}$ & $\begin{array}{c}0.173 \\
(0.114)\end{array}$ & $\begin{array}{c}0.094 \\
(0.133)\end{array}$ & $\begin{array}{c}0.089 \\
(0.084)\end{array}$ & $\begin{array}{l}-0.044 \\
(0.121)\end{array}$ & $\begin{array}{c}0.064 \\
(0.118)\end{array}$ & $\begin{array}{c}0.010 \\
(0.114)\end{array}$ \\
\hline Pessimism & $\begin{array}{c}-0.119 * * * \\
(0.044)\end{array}$ & $\begin{array}{l}-0.085 \\
(0.071)\end{array}$ & $\begin{array}{c}0.099 \\
(0.106)\end{array}$ & $\begin{array}{c}-0.231^{*} \\
(0.137)\end{array}$ & $\begin{array}{c}-0.011 \\
(0.109)\end{array}$ & $\begin{array}{c}-0.072 \\
(0.083)\end{array}$ & $\begin{array}{l}-0.075 \\
(0.127)\end{array}$ & $\begin{array}{l}-0.094 \\
(0.121)\end{array}$ & $\begin{array}{l}-0.018 \\
(0.106)\end{array}$ \\
\hline People trust & $\begin{array}{c}-0.013 \\
(0.009)\end{array}$ & $\begin{array}{c}-0.033^{*} \\
(0.019)\end{array}$ & $\begin{array}{c}0.025 \\
(0.026)\end{array}$ & $\begin{array}{l}0.020 \\
(0.027)\end{array}$ & $\begin{array}{c}0.043 \\
(0.029)\end{array}$ & $\begin{array}{l}-0.015 \\
(0.020)\end{array}$ & $\begin{array}{l}-0.005 \\
(0.027)\end{array}$ & $\begin{array}{c}0.013 \\
(0.028)\end{array}$ & $\begin{array}{c}-0.002 \\
(0.026)\end{array}$ \\
\hline More trustworthy of other people & $\begin{array}{l}0.080^{*} \\
(0.044)\end{array}$ & $\begin{array}{c}0.078 \\
(0.074)\end{array}$ & $\begin{array}{c}0.089 \\
(0.098)\end{array}$ & $\begin{array}{c}-0.188^{*} \\
(0.108)\end{array}$ & $\begin{array}{c}0.101 \\
(0.121)\end{array}$ & $\begin{array}{c}0.209^{* *} \\
(0.083)\end{array}$ & $\begin{array}{l}-0.113 \\
(0.122)\end{array}$ & $\begin{array}{l}-0.149 \\
(0.122)\end{array}$ & $\begin{array}{c}-0.244^{*} \\
(0.135)\end{array}$ \\
\hline Interested in savings program & $\begin{array}{c}0.055 \\
(0.055)\end{array}$ & $\begin{array}{c}0.016 \\
(0.087)\end{array}$ & $\begin{array}{c}0.039 \\
(0.121)\end{array}$ & $\begin{array}{l}0.070 \\
(0.121)\end{array}$ & $\begin{array}{c}0.074 \\
(0.148)\end{array}$ & $\begin{array}{c}0.083 \\
(0.100)\end{array}$ & $\begin{array}{c}0.047 \\
(0.127)\end{array}$ & $\begin{array}{l}-0.112 \\
(0.116)\end{array}$ & $\begin{array}{l}-0.048 \\
(0.119)\end{array}$ \\
\hline $\begin{array}{l}\text { There are lots of ways around } \\
\text { any problem that I am facing now }\end{array}$ & $\begin{array}{l}0.025 \\
(0.059)\end{array}$ & $\begin{array}{c}0.014 \\
(0.097)\end{array}$ & $\begin{array}{l}-0.030 \\
(0.108)\end{array}$ & $\begin{array}{l}0.057 \\
(0.109)\end{array}$ & $\begin{array}{l}-0.018 \\
(0.127)\end{array}$ & $\begin{array}{c}0.069 \\
(0.097)\end{array}$ & $\begin{array}{l}-0.034 \\
(0.105)\end{array}$ & $\begin{array}{l}-0.034 \\
(0.128)\end{array}$ & $\begin{array}{l}-0.100 \\
(0.123)\end{array}$ \\
\hline Is meeting her goals & $\begin{array}{l}0.088^{*} \\
(0.052)\end{array}$ & $\begin{array}{c}0.161^{* *} \\
(0.078)\end{array}$ & $\begin{array}{l}-0.063 \\
(0.102)\end{array}$ & $\begin{array}{l}-0.151 \\
(0.101)\end{array}$ & $\begin{array}{l}-0.106 \\
(0.108)\end{array}$ & $\begin{array}{c}0.193^{* *} \\
(0.087)\end{array}$ & $\begin{array}{l}-0.037 \\
(0.107)\end{array}$ & $\begin{array}{l}-0.154 \\
(0.120)\end{array}$ & $\begin{array}{l}-0.212^{*} \\
(0.118)\end{array}$ \\
\hline
\end{tabular}

Self-efficacy

Future orientation

Social capital

Notes: $* * *$ significant at $1 \%, * *$ significant at $5 \%, *$ significant at $10 \%$ (based on $p$-values unadjusted for multiple-hypothesis testing). Clustered standard errors at the municipality level in parenthesis. Column (1) shows regression coefficient of the treatment for the whole sample (average effect). Columns (2) to (5) and (6) to (9) show coefficients of the regression that includes interaction terms of the treatment variable with SISBEN points and age, respectively. 
Table 54: Heterogeneous effects: Third follow-up Tablet (Pooled Treatment) effect on Psychosocial Indicators

\begin{tabular}{|c|c|c|c|c|c|c|c|}
\hline & \multirow[b]{2}{*}{$\begin{array}{l}\text { Total } \\
(1)\end{array}$} & \multicolumn{2}{|c|}{ Area } & \multicolumn{2}{|c|}{ Region } & \multicolumn{2}{|c|}{ Schooling } \\
\hline & & $\begin{array}{l}\text { Urban } \\
(2)\end{array}$ & $\begin{array}{c}\text { Rural } \\
(3)\end{array}$ & $\begin{array}{c}\text { Caribe } \\
(4)\end{array}$ & $\begin{array}{c}\text { Pacifico } \\
(5)\end{array}$ & $\begin{array}{l}\text { Primary } \\
(6)\end{array}$ & $\begin{array}{c}\text { Secondary } \\
(7)\end{array}$ \\
\hline Optimism & $\begin{array}{c}0.027 \\
(0.046)\end{array}$ & $\begin{array}{c}-0.025 \\
(0.060)\end{array}$ & $\begin{array}{c}0.077 \\
(0.070)\end{array}$ & $\begin{array}{c}0.004 \\
(0.056)\end{array}$ & $\begin{array}{c}0.099 \\
(0.086)\end{array}$ & $\begin{array}{c}0.086 \\
(0.072)\end{array}$ & $\begin{array}{c}-0.031 \\
(0.048)\end{array}$ \\
\hline Pessimism & $\begin{array}{l}-0.055 \\
(0.060)\end{array}$ & $\begin{array}{c}0.079 \\
(0.071)\end{array}$ & $\begin{array}{c}-0.182^{* *} \\
(0.076)\end{array}$ & $\begin{array}{c}0.020 \\
(0.074)\end{array}$ & $\begin{array}{c}-0.248^{* *} \\
(0.104)\end{array}$ & $\begin{array}{l}-0.133 \\
(0.086)\end{array}$ & $\begin{array}{c}0.012 \\
(0.058)\end{array}$ \\
\hline People trust & $\begin{array}{l}-0.024 \\
(0.015)\end{array}$ & $\begin{array}{l}-0.005 \\
(0.018)\end{array}$ & $\begin{array}{c}-0.041^{*} \\
(0.022)\end{array}$ & $\begin{array}{l}-0.007 \\
(0.019)\end{array}$ & $\begin{array}{c}-0.040^{*} \\
(0.022)\end{array}$ & $\begin{array}{c}-0.054^{* * *} \\
(0.019)\end{array}$ & $\begin{array}{c}0.006 \\
(0.019)\end{array}$ \\
\hline
\end{tabular}

Interested in savings program

There are lots of ways around any problem that I am facing now

Is meeting her goals

\begin{tabular}{lcccccccc} 
Self-efficacy & 0.048 & $0.108^{*}$ & -0.011 & $0.098^{*}$ & -0.080 & 0.056 & 0.041 \\
& $(0.053)$ & $(0.064)$ & $(0.072)$ & $(0.055)$ & $(0.126)$ & $(0.070)$ & $(0.066)$ \\
Future orientation & 0.065 & $0.105^{* *}$ & 0.017 & 0.076 & 0.021 & $0.151^{* *}$ & 0.001 \\
& $(0.044)$ & $(0.049)$ & $(0.069)$ & $(0.048)$ & $(0.091)$ & $(0.067)$ & $(0.053)$ \\
Social capital & 0.085 & 0.036 & $0.129^{*}$ & 0.050 & 0.130 & $0.124^{*}$ & 0.037 \\
& $(0.055)$ & $(0.070)$ & $(0.076)$ & $(0.068)$ & $(0.094)$ & $(0.069)$ & $(0.070)$ \\
\hline
\end{tabular}

Notes: *** significant at $1 \%, * *$ significant at $5 \%, *$ significant at $10 \%$ (based on $p$-values unadjusted for multiple-hypothesis testing). Clustered standard errors at the municipality level in parenthesis. Column (1) shows regression coefficient of the treatment for the whole sample (average effect). Columns (2) to ( 7 ) show coefficients of the treatment in the regression for each sub-sample. 
Table 55: Heterogeneous effects: Third follow-up Tablet (Pooled Treatment) effect on Psychosocial Indicators

\begin{tabular}{|c|c|c|c|c|c|c|c|c|c|}
\hline & \multirow[b]{2}{*}{$\begin{array}{l}\text { Total } \\
(1)\end{array}$} & \multicolumn{4}{|c|}{ Interactions with SISBEN points quartiles } & \multicolumn{4}{|c|}{ Interactions with age quartiles } \\
\hline & & $\begin{array}{c}\text { Treat } \\
(2)\end{array}$ & $\begin{array}{c}\text { Treat*Q2 } \\
(3)\end{array}$ & $\begin{array}{c}\text { Treat*Q3 } \\
\text { (4) }\end{array}$ & $\begin{array}{c}\text { Treat* }{ }^{*} 4 \\
(5)\end{array}$ & $\begin{array}{l}\text { Treat } \\
(6)\end{array}$ & $\begin{array}{c}\text { Treat*Q2 } \\
(7)\end{array}$ & $\begin{array}{c}\text { Treat*Q33 } \\
(8)\end{array}$ & $\begin{array}{c}\text { Treat*Q4 } \\
(9)\end{array}$ \\
\hline Optimism & $\begin{array}{c}0.027 \\
(0.046)\end{array}$ & $\begin{array}{c}0.139 \\
(0.094)\end{array}$ & $\begin{array}{l}-0.119 \\
(0.112)\end{array}$ & $\begin{array}{c}-0.130 \\
(0.126)\end{array}$ & $\begin{array}{c}-0.263^{*} \\
(0.145)\end{array}$ & $\begin{array}{c}0.144 \\
(0.091)\end{array}$ & $\begin{array}{l}-0.159 \\
(0.114)\end{array}$ & $\begin{array}{c}-0.144 \\
(0.106)\end{array}$ & $\begin{array}{c}-0.153 \\
(0.112)\end{array}$ \\
\hline Pessimism & $\begin{array}{c}-0.055 \\
(0.060)\end{array}$ & $\begin{array}{c}-0.127 \\
(0.103)\end{array}$ & $\begin{array}{c}-0.031 \\
(0.119)\end{array}$ & $\begin{array}{c}0.191 \\
(0.135)\end{array}$ & $\begin{array}{c}0.164 \\
(0.132)\end{array}$ & $\begin{array}{c}-0.066 \\
(0.090)\end{array}$ & $\begin{array}{c}0.010 \\
(0.119)\end{array}$ & $\begin{array}{c}0.005 \\
(0.120)\end{array}$ & $\begin{array}{c}0.026 \\
(0.132)\end{array}$ \\
\hline People trust & $\begin{array}{c}-0.024 \\
(0.015)\end{array}$ & $\begin{array}{c}-0.066^{* * *} \\
(0.023)\end{array}$ & $\begin{array}{c}0.017 \\
(0.040)\end{array}$ & $\begin{array}{c}0.061^{* *} \\
(0.029)\end{array}$ & $\begin{array}{c}0.110^{* * *} \\
(0.030)\end{array}$ & $\begin{array}{l}-0.018 \\
(0.028)\end{array}$ & $\begin{array}{l}-0.017 \\
(0.039)\end{array}$ & $\begin{array}{c}0.003 \\
(0.040)\end{array}$ & $\begin{array}{c}-0.008 \\
(0.040)\end{array}$ \\
\hline
\end{tabular}

Interested in savings program

There are lots of ways around

any problem that I am facing now

Is meeting her goals

\begin{tabular}{|c|c|c|c|c|c|c|c|c|c|}
\hline Self-efficacy & $\begin{array}{c}0.048 \\
(0.053)\end{array}$ & $\begin{array}{c}0.094 \\
(0.089)\end{array}$ & $\begin{array}{l}-0.131 \\
(0.108)\end{array}$ & $\begin{array}{l}-0.033 \\
(0.113)\end{array}$ & $\begin{array}{l}-0.029 \\
(0.120)\end{array}$ & $\begin{array}{c}0.093 \\
(0.083)\end{array}$ & $\begin{array}{l}-0.060 \\
(0.109)\end{array}$ & $\begin{array}{l}-0.105 \\
(0.106)\end{array}$ & $\begin{array}{l}-0.019 \\
(0.118)\end{array}$ \\
\hline Future orientation & $\begin{array}{c}0.065 \\
(0.044)\end{array}$ & $\begin{array}{c}0.122^{*} \\
(0.072)\end{array}$ & $\begin{array}{c}0.038 \\
(0.122)\end{array}$ & $\begin{array}{c}-0.210^{*} \\
(0.119)\end{array}$ & $\begin{array}{c}-0.070 \\
(0.107)\end{array}$ & $\begin{array}{c}0.138^{*} \\
(0.073)\end{array}$ & $\begin{array}{c}0.033 \\
(0.103)\end{array}$ & $\begin{array}{c}-0.286^{* * *} \\
(0.100)\end{array}$ & $\begin{array}{l}-0.027 \\
(0.120)\end{array}$ \\
\hline Social capital & $\begin{array}{c}0.085 \\
(0.055)\end{array}$ & $\begin{array}{c}0.056 \\
(0.088)\end{array}$ & $\begin{array}{c}0.080 \\
(0.128)\end{array}$ & $\begin{array}{c}0.020 \\
(0.120)\end{array}$ & $\begin{array}{c}0.015 \\
(0.119)\end{array}$ & $\begin{array}{l}-0.013 \\
(0.095)\end{array}$ & $\begin{array}{c}0.087 \\
(0.115)\end{array}$ & $\begin{array}{c}0.121 \\
(0.118)\end{array}$ & $\begin{array}{c}0.179 \\
(0.122)\end{array}$ \\
\hline
\end{tabular}

Notes: *** significant at $1 \%, * *$ significant at $5 \%, *$ significant at $10 \%$ (based on $p$-values unadjusted for multiple-hypothesis testing). Clustered standard errors at the municipality level in parenthesis. Column (1) shows regression coefficient of the treatment for the whole sample (average effect). Columns (2) to (5) and (6) to (9) show coefficients of the regression that includes interaction terms of the treatment variable with SISBEN points and age, respectively. 


\section{Results: SMS vs. Tablet Only Treatment}

The evaluation's second intervention consisted of sending SMS nudge messages to a selection of treated beneficiaries of the LISTA program. Evidence indicates that text messages augmented in some areas the effects of the tablet program. There was a positive impact on the acquisition of financial knowledge and self-reported financial performance. However, there is a limited effect on the practice adoption and general attitudes.

No impact is found on financial preferences and attitudes. A possible explanation is that the text message content did not target the CCT recipients' attitudes towards financial institutions, with only one of the text messages discussing banks (and the message conveyed was that of saving in formal entities as the safest alternative).

Financial practices. The SMS's effect on the adoption of financial practices appears limited. There was no effect on saving or budgeting practices, ranging from having a savings goal to keeping written accounts. However, there may be an impact on MFA-related practices. The SMS treatment increased the probability of leaving the card with family members and friends. Even if this result is not ideal from an MFA program perspective (i.e., MFA cards should be personal and nontransferable items), it might reflect LISTA's impact on beneficiaries teaching someone else to use an ATM. This hypothesis is supported by the fact that having been part of the SMS treatment group decreases the probability of being accompanied by someone to use the ATM by 13 percentage points.

Financial performance. Analysis suggests that the SMS intervention had a positive and significant effect on self-reported financial performance. There is an impact of SMS treatment on beneficiary's total and informal amount of savings, including savings at home. These results are consistent with the SMS content, in the sense that most of the messages encourage saving practices. When considering the financial practices and performance results together, there is indication that the SMS treatment had an effect at the intensive rather than the extensive margins. It appears to have increased the magnitudes of those who acquired more knowledge and were already saving, but it did not increase the number of people who saved compared to the tablet-only treatment, suggesting that what sparked the savings habit was the tablet app itself.

Psychosocial Indicators. No impact was detected impact on the attitudes and preferences of the treated beneficiaries for the SMS intervention. Once again, this may be due in large part to the content of these messages, which did not target directly these behavioral or empowerment components, although one could hypothesize that with increased knowledge and informal savings the beneficiary may indirectly increase her sense of self-efficacy and optimism. 
Table 56: Impact of LISTA SMS (vs. Tablet only) on Financial Knowledge

\begin{tabular}{|c|c|c|c|c|c|c|c|c|c|}
\hline & \multicolumn{3}{|c|}{ First follow-up } & \multicolumn{3}{|c|}{ Second follow-up } & \multicolumn{3}{|c|}{ Third follow-up } \\
\hline & Obs & Control & Treatment & Obs & Control & Treatment & Obs & Control & Treatment \\
\hline Knowledge: total score & 938 & 2.357 & $\begin{array}{c}0.034 \\
(0.068)\end{array}$ & 1,127 & 5.635 & $\begin{array}{c}0.213^{* * *} \\
(0.064)\end{array}$ & 1,010 & 5.405 & $\begin{array}{c}0.082 \\
(0.084)\end{array}$ \\
\hline Knowledge: savings section & 938 & 0.989 & $\begin{array}{c}0.114^{*} \\
(0.058) \\
{[0.144]}\end{array}$ & 1,127 & 2.277 & $\begin{array}{c}0.215^{* * *} \\
(0.060) \\
{[0.000]}\end{array}$ & 1,010 & 2.132 & $\begin{array}{c}0.053 \\
(0.080) \\
{[0.732]}\end{array}$ \\
\hline Knowledge: budget section & 938 & 0.681 & $\begin{array}{l}-0.034 \\
(0.070) \\
{[0.812]}\end{array}$ & 1,127 & 1.607 & $\begin{array}{c}0.103 \\
(0.064) \\
{[0.211]}\end{array}$ & 1,010 & 1.600 & $\begin{array}{c}0.012 \\
(0.059) \\
{[0.836]}\end{array}$ \\
\hline Knowledge: debt section & 938 & 0.687 & $\begin{array}{l}-0.043 \\
(0.077) \\
{[0.812]}\end{array}$ & 1,127 & 1.750 & $\begin{array}{c}0.040 \\
(0.074) \\
{[0.594]}\end{array}$ & 1,010 & 1.673 & $\begin{array}{c}0.089 \\
(0.083) \\
{[0.614]}\end{array}$ \\
\hline Knowledge extended: total score & & & & 1,127 & 8.736 & $\begin{array}{c}0.194^{* * *} \\
(0.065)\end{array}$ & 1,010 & 7.953 & $\begin{array}{c}0.037 \\
(0.079)\end{array}$ \\
\hline Knowledge extended: savings & & & & 1,127 & 3.159 & $\begin{array}{c}0.262^{* * *} \\
(0.062) \\
{[0.000]}\end{array}$ & 1,010 & 2.992 & $\begin{array}{c}0.077 \\
(0.084) \\
{[0.729]}\end{array}$ \\
\hline Knowledge extended: budget & & & & 1,127 & 2.305 & $\begin{array}{c}0.069 \\
(0.057) \\
{[0.477]}\end{array}$ & 1,010 & 2.073 & $\begin{array}{l}-0.012 \\
(0.055) \\
{[0.968]}\end{array}$ \\
\hline Knowledge extended: debt & & & & 1,127 & 3.272 & $\begin{array}{c}0.042 \\
(0.065) \\
{[0.533]}\end{array}$ & 1,010 & 2.887 & $\begin{array}{c}0.005 \\
(0.075) \\
{[0.968]}\end{array}$ \\
\hline Knowledge extended: math & & & & 1,127 & 1.647 & $\begin{array}{c}-0.081 \\
(0.063) \\
{[0.477]}\end{array}$ & & & \\
\hline
\end{tabular}

Notes: ${ }^{* *}$ significant at $1 \%,{ }^{* *}$ significant at $5 \%,{ }^{*}$ significant at $10 \%$ (based on $p$-values unadjusted for multiple-hypothesis testing). Clustered standard errors at the "mother leader" level in parenthesis. 
Table 57: Impact of LISTA SMS (vs. Tablet only) on Financial Attitudes

\begin{tabular}{|c|c|c|c|c|c|c|c|c|c|}
\hline & \multicolumn{3}{|c|}{ First follow-up } & \multicolumn{3}{|c|}{ Second follow-up } & \multicolumn{3}{|c|}{ Third follow-up } \\
\hline & Obs & Control & Treatment & Obs & Control & Treatment & Obs & Control & Treatment \\
\hline Has a savings goal & 1,497 & 0.242 & $\begin{array}{l}0.038 \\
(0.024) \\
{[0.955]}\end{array}$ & 1,127 & 0.321 & $\begin{array}{l}0.002 \\
(0.044) \\
{[0.995]}\end{array}$ & 1,010 & 0.368 & $\begin{array}{l}0.018 \\
(0.037) \\
{[0.948]}\end{array}$ \\
\hline Believes can leave money in MFA account & 1,063 & 0.341 & $\begin{array}{c}-0.049^{*} \\
(0.029) \\
{[0.347]}\end{array}$ & 695 & 0.722 & $\begin{array}{l}-0.014 \\
(0.042) \\
{[0.995]}\end{array}$ & 688 & 0.781 & $\begin{array}{l}-0.062 \\
(0.037) \\
{[0.417]}\end{array}$ \\
\hline Trust in bank & 659 & 1.289 & $\begin{array}{l}0.023 \\
(0.061) \\
{[0.955]}\end{array}$ & 777 & 2.796 & $\begin{array}{l}-0.030 \\
(0.077) \\
{[0.995]}\end{array}$ & 711 & 2.643 & $\begin{array}{l}-0.050 \\
(0.110) \\
{[0.915]}\end{array}$ \\
\hline Comfort with banks & 647 & 1.124 & $\begin{array}{l}-0.029 \\
(0.068) \\
{[0.955]}\end{array}$ & 769 & 2.487 & $\begin{array}{l}0.037 \\
(0.094) \\
{[0.995]}\end{array}$ & 708 & 2.642 & $\begin{array}{l}0.108 \\
(0.068) \\
{[0.417]}\end{array}$ \\
\hline Preference: money in bank vs. cash & 660 & 1.658 & $\begin{array}{l}-0.044 \\
(0.049) \\
{[0.788]}\end{array}$ & 796 & 2.959 & $\begin{array}{l}0.010 \\
(0.069) \\
{[0.995]}\end{array}$ & 727 & 3.132 & $\begin{array}{l}-0.069 \\
(0.075) \\
{[0.792]}\end{array}$ \\
\hline Intertemporal preference: today vs. one month & & & & 795 & 3.021 & $\begin{array}{l}0.026 \\
(0.089) \\
{[0.995]}\end{array}$ & 724 & 2.899 & $\begin{array}{l}-0.054 \\
(0.095) \\
{[0.915]}\end{array}$ \\
\hline
\end{tabular}

Notes: ${ }^{* * *}$ significant at $1 \%,{ }^{* *}$ significant at $5 \%,{ }^{*}$ significant at $10 \%$ (based on $p$-values unadjusted for multiple-hypothesis testing). Clustered standard errors at the "mother leader" level in parenthesis. 
Table 58: Impact of LISTA SMS (vs. Tablet only) on Financial Practices (ATM, MFA)

\begin{tabular}{|c|c|c|c|c|c|c|c|c|c|}
\hline & \multicolumn{3}{|c|}{ First follow-up } & \multicolumn{3}{|c|}{ Second follow-up } & \multicolumn{3}{|c|}{ Third follow-up } \\
\hline & Obs & Control & Treatment & Obs & Control & Treatment & Obs & Control & Treatment \\
\hline Manages household finances & 654 & 0.957 & $\begin{array}{c}-0.029^{* *} \\
(0.012) \\
{[0.057]}\end{array}$ & 769 & 0.921 & $\begin{array}{c}0.004 \\
(0.016) \\
{[0.998]}\end{array}$ & 704 & 0.942 & $\begin{array}{c}0.015 \\
(0.018) \\
{[0.945]}\end{array}$ \\
\hline Keeps written track of accounts & 1,030 & 0.118 & $\begin{array}{c}0.043 \\
(0.030) \\
{[0.369]}\end{array}$ & 729 & 0.175 & $\begin{array}{l}-0.007 \\
(0.035) \\
{[0.998]}\end{array}$ & 677 & 0.326 & $\begin{array}{c}0.075 \\
(0.051) \\
{[0.659]}\end{array}$ \\
\hline Withdrew last MFA transfer & 1,035 & 0.367 & $\begin{array}{c}-0.016 \\
(0.019) \\
{[0.629]}\end{array}$ & 768 & 0.791 & $\begin{array}{c}0.030 \\
(0.031) \\
{[0.928]}\end{array}$ & 682 & 0.847 & $\begin{array}{l}-0.007 \\
(0.022) \\
{[0.978]}\end{array}$ \\
\hline Accompanied when withdrew & 977 & 0.192 & $\begin{array}{c}0.006 \\
(0.042) \\
{[0.872]}\end{array}$ & 490 & 0.521 & $\begin{array}{c}0.005 \\
(0.063) \\
{[0.998]}\end{array}$ & 669 & 0.447 & $\begin{array}{l}-0.001 \\
(0.040) \\
{[0.978]}\end{array}$ \\
\hline Has money in MFA account (today) & & & & 605 & 0.382 & $\begin{array}{c}0.053 \\
(0.054) \\
{[0.928]}\end{array}$ & 611 & 0.504 & $\begin{array}{c}0.036 \\
(0.045) \\
{[0.945]}\end{array}$ \\
\hline Leaves money in MFA account & & & & 687 & 0.397 & $\begin{array}{c}0.002 \\
(0.050) \\
{[0.998]}\end{array}$ & 667 & 0.444 & $\begin{array}{c}0.014 \\
(0.052) \\
{[0.978]}\end{array}$ \\
\hline Someone helped use ATM & & & & 257 & 0.663 & $\begin{array}{c}-0.137^{*} \\
(0.077) \\
{[0.462]}\end{array}$ & 297 & 0.578 & $\begin{array}{c}0.031 \\
(0.057) \\
{[0.957]}\end{array}$ \\
\hline Feels can teach ATM use & & & & 760 & 0.428 & $\begin{array}{c}0.061 \\
(0.053) \\
{[0.869]}\end{array}$ & 702 & 0.556 & $\begin{array}{c}0.060 \\
(0.039) \\
{[0.649]}\end{array}$ \\
\hline Has taught someone use ATM & & & & 760 & 0.242 & $\begin{array}{c}0.037 \\
(0.035) \\
{[0.913]}\end{array}$ & 702 & 0.269 & $\begin{array}{c}0.083^{* *} \\
(0.039) \\
{[0.248]}\end{array}$ \\
\hline Has a MFA card & & & & 768 & 0.847 & $\begin{array}{c}0.007 \\
(0.023) \\
{[0.996]}\end{array}$ & 684 & 0.970 & $\begin{array}{c}0.010 \\
(0.011) \\
{[0.921]}\end{array}$ \\
\hline
\end{tabular}

Notes: ${ }^{* *}$ significant at $1 \%,{ }^{* *}$ significant at $5 \%,{ }^{*}$ significant at $10 \%$ (based on $p$-values unadjusted for multiple-hypothesis testing). Clustered standard errors at the "mother leader" level in parenthesis. 
Table 59: Impact of LISTA SMS (vs. Tablet only) on Financial Practices (Budget)

\begin{tabular}{|c|c|c|c|c|c|c|c|c|c|}
\hline & \multicolumn{3}{|c|}{ First follow-up } & \multicolumn{3}{|c|}{ Second follow-up } & \multicolumn{3}{|c|}{ Third follow-up } \\
\hline & Obs & Control & Treatment & Obs & Control & Treatment & Obs & Control & Treatment \\
\hline \multicolumn{10}{|l|}{ In case of a $350 \mathrm{k}$ emergency } \\
\hline Would use savings & 918 & 0.420 & $\begin{array}{c}0.009 \\
(0.032) \\
{[0.915]}\end{array}$ & 1,088 & 0.143 & $\begin{array}{c}-0.017 \\
(0.033) \\
{[0.802]}\end{array}$ & 985 & 0.144 & $\begin{array}{c}-0.007 \\
(0.028) \\
{[0.969]}\end{array}$ \\
\hline Would use loans & 918 & 0.533 & $\begin{array}{c}0.003 \\
(0.030) \\
{[0.926]}\end{array}$ & 1,088 & 0.734 & $\begin{array}{c}0.028 \\
(0.031) \\
{[0.611]}\end{array}$ & 985 & 0.764 & $\begin{array}{c}0.007 \\
(0.029) \\
{[0.961]}\end{array}$ \\
\hline Would sell or pawn something & 918 & 0.033 & $\begin{array}{l}-0.010 \\
(0.010) \\
{[0.598]}\end{array}$ & 1,088 & 0.115 & $\begin{array}{l}-0.003 \\
(0.024) \\
{[0.881]}\end{array}$ & 985 & 0.051 & $\begin{array}{l}-0.006 \\
(0.019) \\
{[0.965]}\end{array}$ \\
\hline Would look for a job & & & & 1,101 & 0.026 & $\begin{array}{c}-0.013^{*} \\
(0.008) \\
{[0.232]}\end{array}$ & 995 & 0.029 & $\begin{array}{c}0.008 \\
(0.012) \\
{[0.832]}\end{array}$ \\
\hline \multicolumn{10}{|l|}{ In case of receiving $300 \mathrm{k}$ extra } \\
\hline Would save & & & & 1,127 & 0.892 & $\begin{array}{l}-0.001 \\
(0.027) \\
{[0.995]}\end{array}$ & 1,009 & 0.863 & $\begin{array}{c}0.021 \\
(0.026) \\
{[0.862]}\end{array}$ \\
\hline Would spend on healthcare or education & & & & 1,127 & 0.097 & $\begin{array}{c}-0.038 \\
(0.024) \\
{[0.430]}\end{array}$ & 1,007 & 0.966 & $\begin{array}{l}-0.004 \\
(0.012) \\
{[0.926]}\end{array}$ \\
\hline Would build, improve or buy a house & & & & 1,120 & 0.782 & $\begin{array}{l}-0.011 \\
(0.028) \\
{[0.969]}\end{array}$ & 1,004 & 0.831 & $\begin{array}{l}-0.027 \\
(0.024) \\
{[0.754]}\end{array}$ \\
\hline Would spend on household expenses & & & & 1,127 & 0.050 & $\begin{array}{c}0.001 \\
(0.012) \\
{[0.995]}\end{array}$ & 1,008 & 0.814 & $\begin{array}{l}-0.016 \\
(0.030) \\
{[0.926]}\end{array}$ \\
\hline Would invest in business & & & & 1,124 & 0.856 & $\begin{array}{l}-0.026 \\
(0.027) \\
{[0.784]}\end{array}$ & 1,007 & 0.899 & $\begin{array}{c}0.010 \\
(0.018) \\
{[0.926]}\end{array}$ \\
\hline Was able to cover household expenses & & & & 1,028 & 0.388 & $\begin{array}{c}-0.058^{*} \\
(0.032) \\
{[0.133]}\end{array}$ & 922 & 0.432 & $\begin{array}{l}-0.021 \\
(0.033) \\
{[0.758]}\end{array}$ \\
\hline Household weekly expenditure & & & & 1,028 & $137,060.984$ & $\begin{array}{l}-0.063 \\
(0.067) \\
{[0.357]}\end{array}$ & 904 & $151,549.219$ & $\begin{array}{l}-0.040 \\
(0.063) \\
{[0.758]}\end{array}$ \\
\hline
\end{tabular}

Notes: $* * *$ significant at $1 \%,{ }^{* *}$ significant at $5 \%, *$ significant at $10 \%$ (based on $p$-values unadjusted for multiple-hypothesis testing). Clustered standard errors at the "mother leader" level in parenthesis. 
Table 60: Impact of LISTA SMS (vs. Tablet only) on Financial Performance (Self - Reported)

\begin{tabular}{|c|c|c|c|c|c|c|c|c|c|}
\hline & \multicolumn{3}{|c|}{ First follow-up } & \multicolumn{3}{|c|}{ Second follow-up } & \multicolumn{3}{|c|}{ Third follow-up } \\
\hline & Obs & Control & Treatment & Obs & Control & Treatment & Obs & Control & Treatment \\
\hline \multicolumn{10}{|l|}{ Panel A: Probability of saving } \\
\hline Has formal and informal savings & 1,541 & 0.045 & $\begin{array}{c}0.018 \\
(0.019)\end{array}$ & 1,127 & 0.043 & $\begin{array}{c}-0.017 \\
(0.016)\end{array}$ & 1,010 & 0.082 & $\begin{array}{c}-0.030 \\
(0.021)\end{array}$ \\
\hline Has formal savings & 1,541 & 0.059 & $\begin{array}{c}0.016 \\
(0.022)\end{array}$ & 1,127 & 0.085 & $\begin{array}{c}-0.019 \\
(0.020)\end{array}$ & 1,010 & 0.132 & $\begin{array}{c}-0.029 \\
(0.024)\end{array}$ \\
\hline Has informal savings & 1,541 & 0.327 & $\begin{array}{c}0.035 \\
(0.028)\end{array}$ & 1,127 & 0.417 & $\begin{array}{c}0.043 \\
(0.035)\end{array}$ & 1,010 & 0.472 & $\begin{array}{c}0.006 \\
(0.036)\end{array}$ \\
\hline Saves money in piggy bank & 1,540 & 0.324 & $\begin{array}{c}0.034 \\
(0.028)\end{array}$ & 1,126 & 0.408 & $\begin{array}{c}0.030 \\
(0.035)\end{array}$ & 1,010 & 0.438 & $\begin{array}{c}0.001 \\
(0.037)\end{array}$ \\
\hline Saves money in bank account & 1,534 & 0.032 & $\begin{array}{c}0.024 \\
(0.016)\end{array}$ & 1,127 & 0.051 & $\begin{array}{c}-0.014 \\
(0.015)\end{array}$ & 1,006 & 0.082 & $\begin{array}{c}-0.047^{* *} \\
(0.020)\end{array}$ \\
\hline Saves money in cooperative & 1,541 & 0.034 & $\begin{array}{l}-0.000 \\
(0.016)\end{array}$ & 1,126 & 0.039 & $\begin{array}{l}-0.010 \\
(0.015)\end{array}$ & 1,009 & 0.061 & $\begin{array}{c}0.004 \\
(0.017)\end{array}$ \\
\hline \multicolumn{10}{|l|}{ Panel B: Tobit estimates for savings } \\
\hline Total formal and informal savings & 938 & 58,144 & $\begin{array}{c}0.253 \\
(0.168)\end{array}$ & 1,127 & 129,173 & $\begin{array}{c}0.264 \\
(0.514)\end{array}$ & 1,010 & 187,946 & $\begin{array}{c}0.031 \\
(0.378)\end{array}$ \\
\hline Total formal savings & 938 & 22,015 & $\begin{array}{c}1.584 \\
(1.091)\end{array}$ & 1,127 & 57,269 & $\begin{array}{c}-0.804 \\
(2.109)\end{array}$ & 1,009 & 79,574 & $\begin{array}{c}-1.783 \\
(1.557)\end{array}$ \\
\hline Total informal savings & 938 & 34,458 & $\begin{array}{c}0.210 \\
(0.159)\end{array}$ & 1,127 & 60,091 & $\begin{array}{c}0.400 \\
(0.393)\end{array}$ & 967 & 101,905 & $\begin{array}{c}0.356 \\
(0.361)\end{array}$ \\
\hline Savings in a piggy bank & 938 & 27,912 & $\begin{array}{c}0.280 \\
(0.177)\end{array}$ & 1,127 & 48,842 & $\begin{array}{c}0.404 \\
(0.372)\end{array}$ & 967 & 77,257 & $\begin{array}{c}0.135 \\
(0.298)\end{array}$ \\
\hline Savings in a bank & 938 & 11,537 & $\begin{array}{c}2.040 \\
(1.395)\end{array}$ & 1,127 & 30,828 & $\begin{array}{c}-1.731 \\
(3.486)\end{array}$ & 1,005 & 34,678 & $\begin{array}{c}-4.234^{* *} \\
(1.953)\end{array}$ \\
\hline
\end{tabular}

Notes: *** significant at $1 \%, * *$ significant at $5 \%, *$ significant at $10 \%$ (based on $p$-values unadjusted for multiple-hypothesis testing). Clustered standard errors at the "mother leader" level in parenthesis. 
Table 61: Impact of LISTA SMS (vs. Tablet only) on Psychosocial Indicators

\begin{tabular}{|c|c|c|c|c|c|c|c|c|c|}
\hline & \multicolumn{3}{|c|}{ First follow-up } & \multicolumn{3}{|c|}{ Second follow-up } & \multicolumn{3}{|c|}{ Third follow-up } \\
\hline & Obs & Control & Treatment & Obs & Control & Treatment & Obs & Control & Treatment \\
\hline Optimism & & & & 1,096 & 5.868 & $\begin{array}{c}0.063 \\
(0.051) \\
{[0.764]}\end{array}$ & 985 & 5.813 & $\begin{array}{c}0.054 \\
(0.084) \\
{[0.942]}\end{array}$ \\
\hline Pessimism & & & & 1,104 & 2.284 & $\begin{array}{l}-0.011 \\
(0.070) \\
{[0.986]}\end{array}$ & 975 & 2.817 & $\begin{array}{l}-0.063 \\
(0.084) \\
{[0.942]}\end{array}$ \\
\hline People trust & & & & 1,115 & 0.050 & $\begin{array}{c}0.008 \\
(0.015) \\
{[0.961]}\end{array}$ & 1,007 & 0.095 & $\begin{array}{c}0.017 \\
(0.023) \\
{[0.942]}\end{array}$ \\
\hline More trustworthy of other people & & & & 1,122 & 1.874 & $\begin{array}{c}0.065 \\
(0.081) \\
{[0.923]}\end{array}$ & & & \\
\hline Interested in savings program & & & & 1,091 & 2.958 & $\begin{array}{l}-0.032 \\
(0.074) \\
{[0.961]}\end{array}$ & & & \\
\hline $\begin{array}{l}\text { There are lots of ways around } \\
\text { any problem that I am facing now }\end{array}$ & & & & 1,127 & 5.679 & $\begin{array}{l}0.005 \\
(0.080) \\
{[0.986]}\end{array}$ & & & \\
\hline $\begin{array}{l}\text { Is meeting her goals } \\
\text { Self-efficacy }\end{array}$ & & & & 1,127 & 5.331 & $\begin{array}{c}0.087 \\
(0.096) \\
{[0.891]}\end{array}$ & & & \\
\hline Future orientation & & & & & & & 1,010 & 3.050 & $\begin{array}{l}-0.123^{*} \\
(0.072) \\
{[0.385]}\end{array}$ \\
\hline Social capital & & & & & & & 1,010 & 3.284 & $\begin{array}{l}-0.029 \\
(0.075) \\
{[0.942]}\end{array}$ \\
\hline & & & & & & & 1,010 & 1.721 & $\begin{array}{c}0.011 \\
(0.078) \\
{[0.942]}\end{array}$ \\
\hline
\end{tabular}

Notes: ${ }^{* * *}$ significant at $1 \%,{ }^{* *}$ significant at $5 \%,{ }^{*}$ significant at $10 \%$ (based on $p$-values unadjusted for multiple-hypothesis testing). Clustered standard errors at the "mother leader" level in parenthesis. 


\section{SMS Messages}

The following messages were sent during the second intervention. Original messages were written in Spanish and were sent out on a weekly basis from November 2015 to March 2016.

Message 1: LISTA program. Hello, from now on you will receive text messages from the program. We invite you to read them all. Thank you for your time and attention.

Message 2: LISTA program. The Más Familias en Acción incentive is almost here. Save part of this money for your GOAL by leaving it in your account.

Message 3: LISTA program. Just as you've seen in the tablet, saving is easier than what you believed. Set a GOAL, manage your household accounts, start today.

Message 4: LISTA program. Remember your goal and think before buying on impulse. The money you save can be used to increase the amount of money in your account or in your piggy bank.

Message 5: LISTA program. Take care of your own and your family's health. Eat fruit, vegetables, grains and drink enough clean water, this way you can save on medical expenses.

Message 6: LISTA program. Remind your family that turning the lights off in your house and closing the water taps is SAVING, it is also a way to take care of our planet.

Message 7: LISTA program. Saving is also buying quality goods with a warranty. Always keep your receipts and warranties in a safe place.

Message 8: LISTA program. You can program your saving every day, week, fortnight or month. The important thing is that after a year you are closer to your GOAL.

Message 9: LISTA program. Hello, did you know that it is more expensive to buy on credit or by borrowing, than by saving. With credit you pay up to three times the actual price of the good. Message 10: LISTA program. When you save, think where you will be saving your money. In a cooperative or in a bank your money is safe, in your house however, it is easily accessible to all.

Message 11: LISTA program. The Más Familias en Acción incentive is almost here. Save part of this money for your GOAL, by leaving it in your account. If you also happen to need a loan, it will be easier to get one with money in your account.

Message 12: LISTA program. If you have a loan, don't commit to another one. You should only borrow money you can repay. If you always pay what you owe, people will lend you money.

Message 13: LISTA program. Take care of everything you have. Your health, family and household belongings. Always have spare money in case of an emergency.

Message 14: LISTA program. If you are thinking of starting a business or improving your own, use part of your MFA incentive to do so. 